Final Report

\title{
WILCOX SANDSTONE RESERVOIRS IN THE DEEP SUBSURFACE ALONG THE TEXAS GULF COAST, THEIR POTENTIAL FOR PRODUCTION OF GEOPRESSURED GEOTHERMAL ENERGY
}

By

D. G. Bebout, B. R. Weise,

A. R. Gregory, and M. B. Edwards

Assisted by
A. D. Allie
H. S. Hamlin
J. L. Lockley
D. A. Budd
J. H. Han
S. D. Mann
V. J. Gavenda
J. C. Herwig
J. S. Posey
B. W. Hainey
A. S. Lawal
M. S. Ritchie

Prepared for the

U.S. Department of Energy

Division of Geothermal Energy

Under Contract No. DE-ASO5-76ET28461

(formerly EY-76-S-05-4891)

Bureau of Economic Geology

W. L. Fisher, Director

The University of Texas at Austin

University Station, P. O. Box X

Austin, Texas 78712

October 1979 


\section{DISCLAIMER}

This report was prepared as an account of work sponsored by an agency of the United States Government. Neither the United States Government nor any agency Thereof, nor any of their employees, makes any warranty, express or implied, or assumes any legal liability or responsibility for the accuracy, completeness, or usefulness of any information, apparatus, product, or process disclosed, or represents that its use would not infringe privately owned rights. Reference herein to any specific commercial product, process, or service by trade name, trademark, manufacturer, or otherwise does not necessarily constitute or imply its endorsement, recommendation, or favoring by the United States Government or any agency thereof. The views and opinions of authors expressed herein do not necessarily state or reflect those of the United States Government or any agency thereof. 


\section{DISCLAIMER}

Portions of this document may be illegible in electronic image products. Images are produced from the best available original document. 
Introduction

Summary and conclusions . . . . . . . . . . . . . . 6

Regional setting . • • • • . . • . . . . . . . . . . 9

Stratigraphic sections . . . . . . . . . . . . . . . . 14

Lower Wilcox sandstone distribution . . . . . . . . . . . . . 40

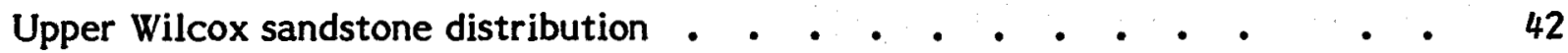

Formation pressure . . . . . . . . . . . . . . 4 46

Formation temperature used to delineate geothermal fairways . . . . . . . . . . . 51

Zapata Fairway . • • • • • • • • • • • • • • • • 58

Duval Fairway

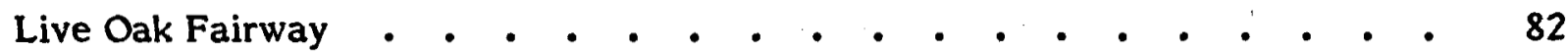

De Witt Fairway - Depositional and structural style . . . . . . . 102

De Witt Fairway - Formation pressures and temperatures . . . . . . 117

De Witt Fairway - Porosity and permeability - . . . . . . . 127

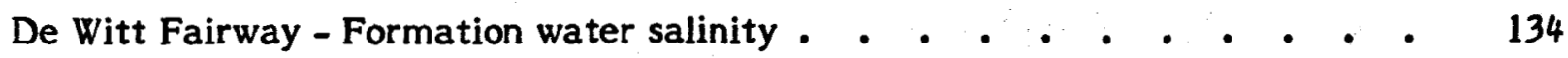

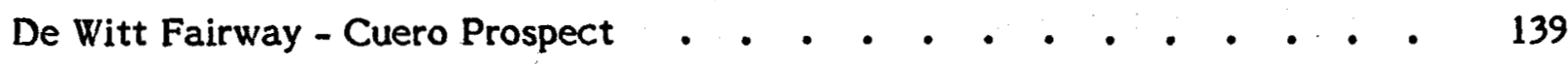

Colorado Fairway - Depositional and structural style $\quad$ • . . . . . 150

Colorado Fairway - Formation and fluid properties . . . . . . . . . 158

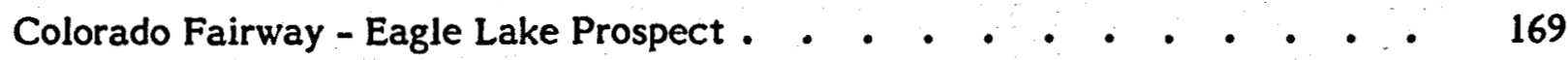

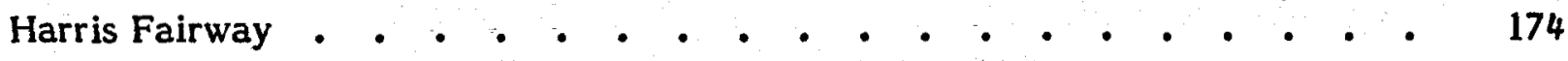

Acknowledgments . . . . . . . . . . . . . . 193

References . . . . . . . . . . . . . . 193

Appendix . . . . . . . . . . . . . . 196 


\section{FIGURES}

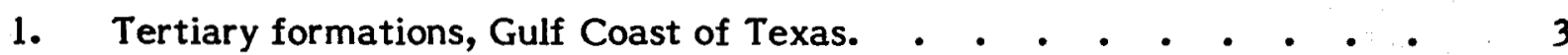

2. Wilcox geothermal corridor. . . . . . . . . . . . . 4

3. Depositional/structural style of the Tertiary along the Texas Gulf Coast. 5

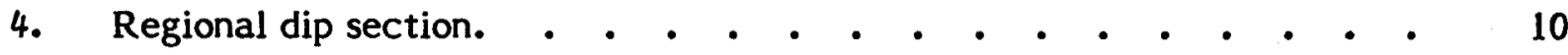

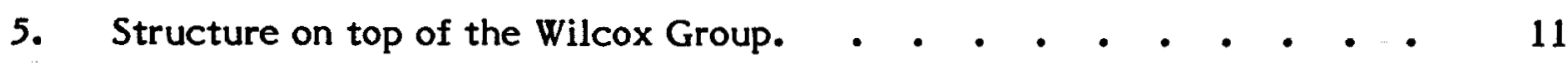

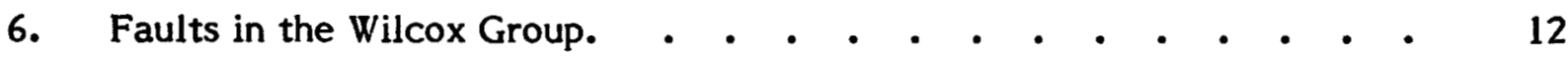

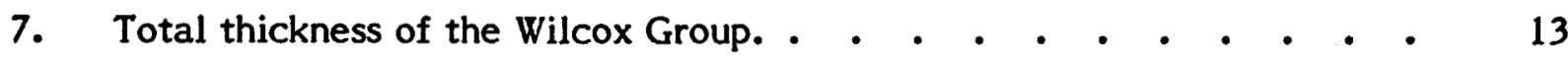

8. Well- $\log$ control and location of sections. . . . . . . . . . 15

9. Electrical log showing division of the Wilcox Group into the sandstone-rich lower and upper parts. . . . . . . . . . . . . 16

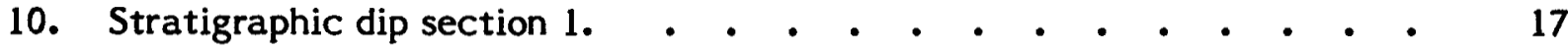

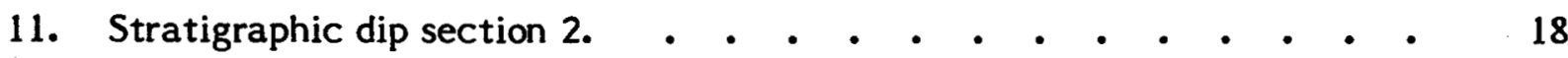

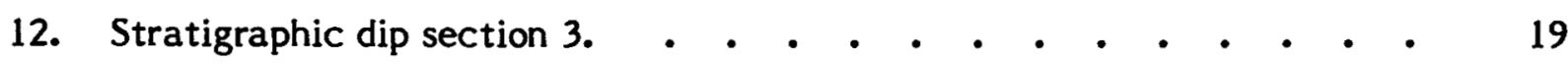

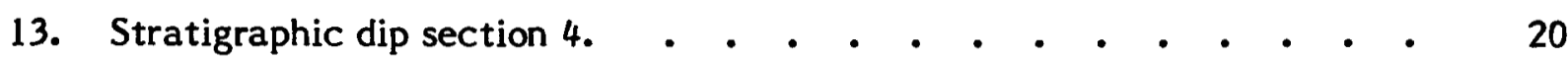

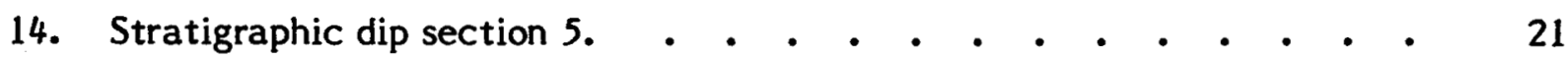

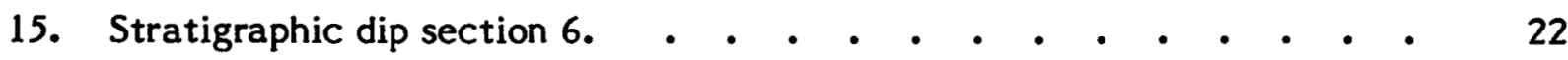

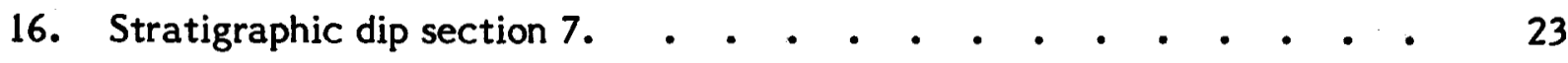

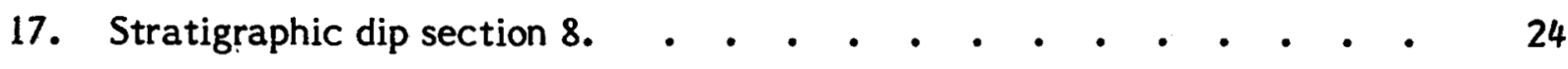

18. Stratigraphic dip section 9. • • • • • • • • • • • • • 25

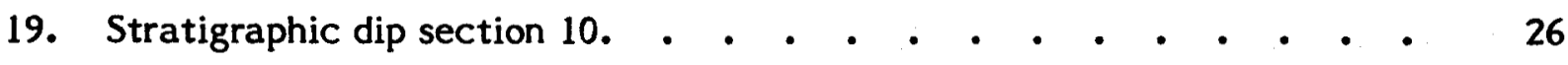

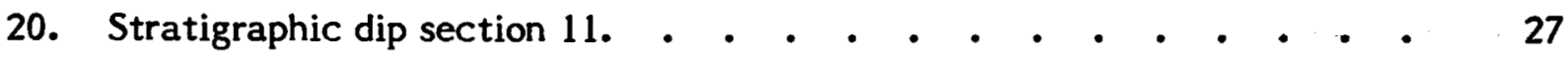

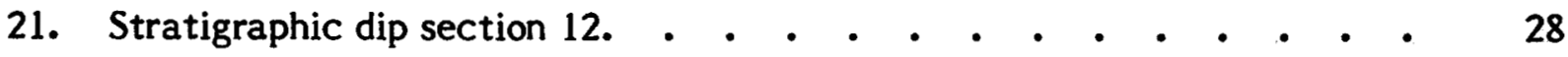

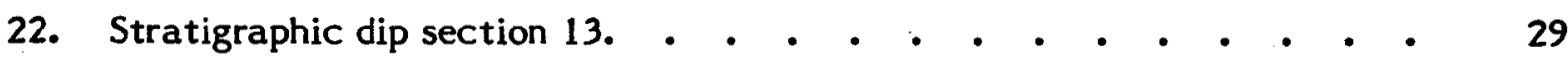

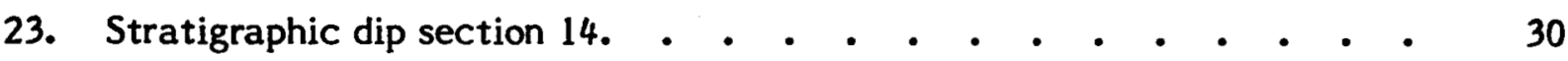




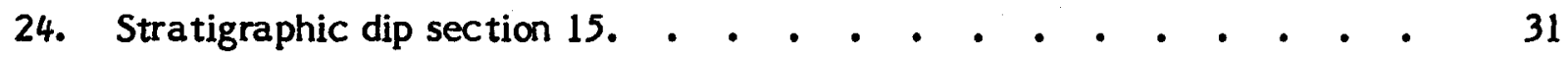

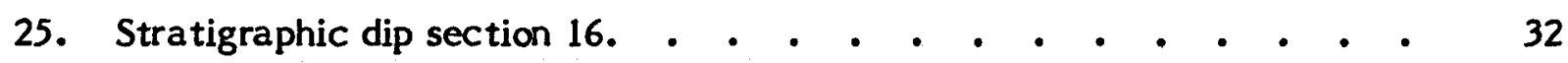

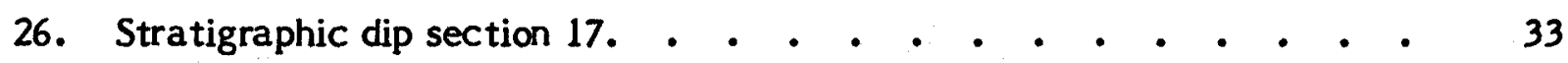

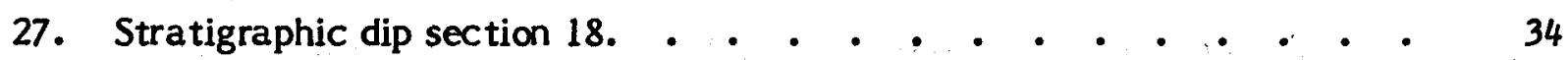

28. Stratigraphic dip section 19. • . . . . . . . . . . . . 35

29. Stratigraphic dip section 20. • • • • • • • • • • • • • 36

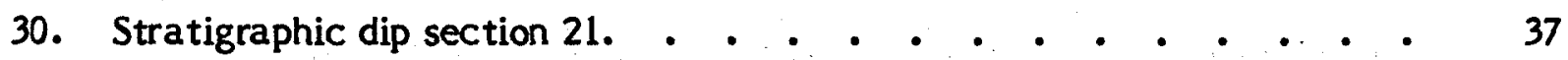

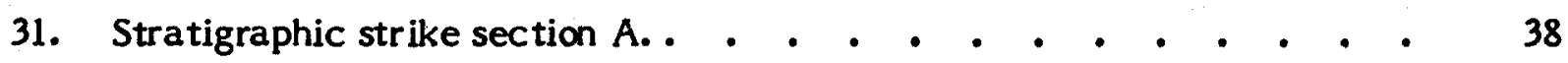

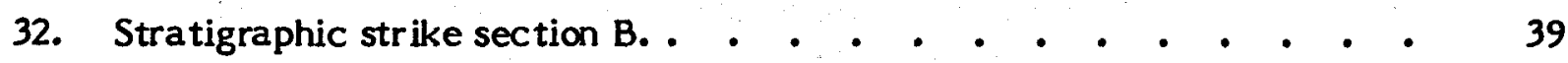

33. Net sandstone, lower Wilcox. . . . . . . . . . . . . . 41

34. Net sandstone, upper Wilcox. . . . . . . . . . . . . . . 44

35. Stratigraphic strike section of the upper Wilcox, Lower Texas Gulf Coast. 45

36. Top of geopressure for a well in De Witt County. • - • • • - • 48

37. Shale resistivity ratio curve obtained for De Witt County. - - . - - 49

38. Top of geopressure within the Wilcox Group, Texas Gulf Coast. - 50

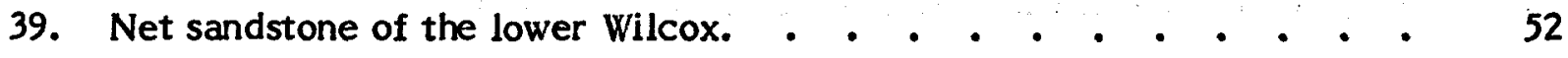

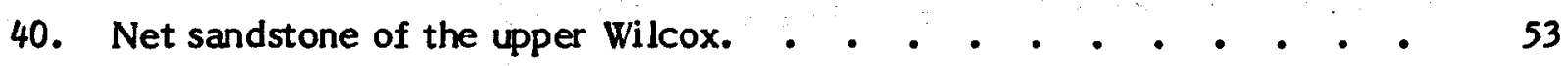

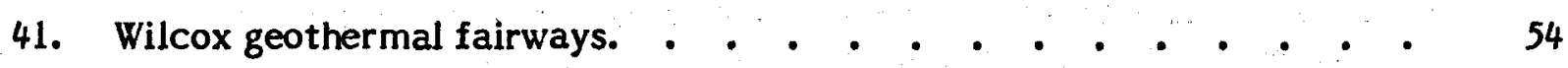

42. Temperatures and geothermal gradients, Harr is County Fairway area. . . $\quad 55$

43. Temperatures and geothermal gradients, De Witt County Fairway area. . 56

44. Temperatures and geothermal gradients for the area including parts of Live Oak, McMullen, Duval, Webb, and Zapata Counties. . . . . . 57

45. Well control, faults at the top of the Wilcox, and area of prospective reservoir sandstones, Zapata Fairway. . . . . . . . . . 61

46. Well control and lines of stratigraphic and structural sections, Zapata Fairway.

47. Structural dip section AA', southern part of the Zapata Fairway. . . . 63

48. Structural dip section CC', central part of the Zapata Fairway. . . - 64 
49. Structural dip section EE', northern part of the Zapata Fairway. .

50. Bottom-hole shut-in pressures for Zapata County. . . . . . . . 66

51. Top of geopressure and geopressure gradients for a well in Zapata County. 67

52. Temperatures and geothermal gradients for Zapata County Fairway area. 68

53. Salinity versus depth for five wells in Zapata County. . - . . - . 69

54. Well control, faults at the top of the Wilcox, and area of prospective reservoirs, Duval Fairway. • • • • • • • • . • • 73

55. Well control and lines of stratigraphic and structural sections, Duval Fairway.

56. Structural dip section AA', Duval Fairway. - • • • • • • • $\quad 75$

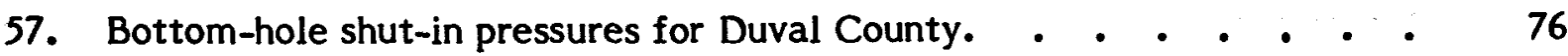

58. Top of geopressure and geopressure gradients for a well on section

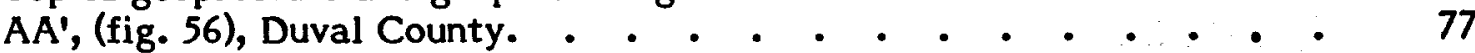

59. Top of geopressure and geopressure gradients for a well in Duval County. 78

60. Top of geopressure and geopressure gradients for a well in Duval County. 79

61. Temperatures and geothermal gradients for Duval.County. . • • • 80

62. Salinity versus depth for five wells in Duval County. . . . . . . 81

63. Well control, faults at the top of the Wilcox, and area of prospective sandstones, Live Oak Fairway. . • • • • • • • • • • • •

64. Well control and lines of stratigraphic and structural sections, Live Oak Fairway and area to the northeast. $\quad . \quad . \quad . \quad . \quad . \quad . \quad 86$

65. Structural dip section AA', southern part of the Live Oak Fairway. . . 87

66. Structural dip section BB', central part of the Live Oak Fairway. . . . 88

67. Structural dip section CC', northern part of the Live Oak Fairway. . . 89

68. Stratigraphic dip section AA', southern part of the Live Oak Fairway. . $\quad 90$

69. Stratigraphic dip section BB', central part of the Live Oak Fairway. . . 91

70. Stratigraphic dip section CC', northern part of the Live Oak Fairway. 92

71. Bottom-hole shut-in pressures for 26 wells in Live Oak County. . - . 93

72. Shale resistivity-versus-depth plot for a non-geopressured well,

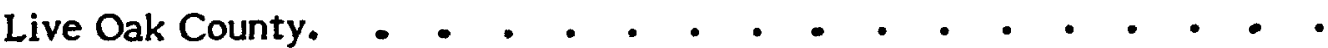


73. Shale resistivity-versus-depth plot for a non-geopressured well section

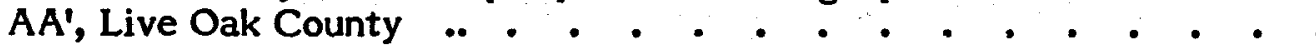

74. Top of geopressure and geopressure gradients for a well on section AA',

Live Oak County. . • • • • • • • • • • • • •

75. Parameter well profile plots showing variation of formation and fluid properties along section AA', Live Oak County. . . . . . . . .

76. Temperatures and geothermal gradients, Live Oak County Fairway area.

77. Temperatures and geothermal gradients for fairway area including parts of Live Oak, McMullen, Duval, Webb, and Zapata Counties. . . .

78. Salinity versus depth for six wells in Live Oak County. . . . . . .

79. A plot of porosity versus depth for six wells in Live Oak County. . . . 101

80. Location of wells and lines of section, De Witt Fairway. . . . . . 104

81. Stratigraphic dip section DD', De Witt Fairway.. . . . . . . 105

82. Net sandstone between correlation markers T2 and T3, middle Wilcox,

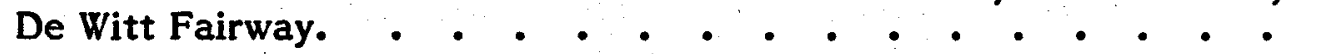

83. Net sandstone between the top of the Wilcox and the TI marker,

De Witt Fairway. • . . . . . . . . • . . 107

84. Structure on top of the D4 marker, De Witt Fairway. . . . . . 108

85. Structural dip section AA', De Witt Fairway. . . . . . . . . 110

86. Structural dip section BB', De Witt Fairway. . . . . . . . . . 111

87. Structural dip section CC', De Witt Fairway. . . . . . . . . 112

88. Structural dip section DD', De Witt Fairway. • • • • • • 113

89. Structural dip section EE', De Witt Fairway. . . . . . . . • • 114

90. Structural dip section FF', De Witt Fairway. . . . . . . . . 115

91. Structural strike section MM', De Witt Fairway. _ _ _ . _ . . 116

92. Bottom-hole shut-in pressure-versus-depth plot for the De Witt

County area. . . . . . . . . . . . .

93. Parameter plots showing shale resistivity profiles and variation of top of geopressure and geopressure gradients along cross section DD',

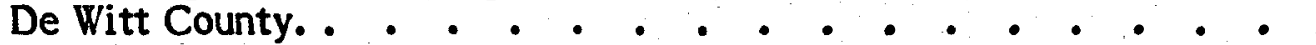

94. Top of geopressure and geopressure gradients from shale resistivity data for updip well cross section DD', De Witt County. . 
95. Top of geopressure and geopressure gradients from shale resistivity data for the type well on cross section DD', De Witt County. . . . .

96. Top of geopressure and geopressure gradients from shale resistivity data for downdip well on cross section DD', De Witt County. . . . .

97. Top of geopressure and geopressure gradients from shale resistivity data for downdip well on cross section DD', De Witt County. . . .

98. Temperatures and geothermal gradients for the De Witt Fairway area. .

99. Temperatures and geothermal gradients for wells located on four fairway cross sections, De Witt County. . . . . . . . . .

100. Parameter plots showing formation temperature profiles and variation of temperature along cross section DD', De Witt County. . . . .

101. Porosity-versus-permeability plot for type well (Cuero prospect) located cross section DD', De Witt County.

102. Porosity-versus-permeability plot for well on cross section BB', De Witt County. .

103. Porosity-versus-permeability plot for well in De Witt County. . .

104. Porosity and permeability-versus-depth plot for type well on section DD', De Witt County.

105. Porosity versus depth for six wells in De Witt County. . . . . .

106. Parameter plots showing porosity profiles and variation of reservoir porosity along cross section DD', De Witt County. . . . . . .

107. Generalized salinity trends as a function of depth in De Witt County. •

108. Salinity versus depth for 11 wells in De Witt County. • • • • . . 136

109. Salinity profile for type well on section DD', De Witt County. . . . . 137

110. Parameter plots showing salinity profile and formation water salinity along section DD', De Witt County. . . . . . . . 138

111. Structure, well control, lines of section, and location of Cuero Prospect.

112. Stratigraphic dip section, Cuero Prospect. . . . . . . . . . 142

113. Stratigraphic strike section and proposed location of test well. . . . 143

114. Net sandstone in correlation unit B, Cuero Prospect. . . . . . . 144

115. Net sandstone in correlation unit C, Cuero Prospect. . . . . . - 145 
116. Net sandstone in correlation unit D, Cuero Prospect.

117. Net sandstone in correlation unit E, Cuero Prospect. . . . . . . 147

118. Net sandstone in correlation unit F, Cuero Prospect. . . . . . . 148

119. Net sandstone in correlation unit G, Cuero Prospect. . . . . . . 149

120. Location of wells and lines of section, Colorado Fairway. . . . . 151

121. Stratigraphic dip section BB, Colorado Fairway. - • • • • . 152

122. Structural map and index section, Colorado Fairway. . . . . . 153

123. Structural dip section AA', Colorado Fairway. . . . • . . 155

124. Structural dip section BB', Colorado Fairway. . . . . . . . . 156

125. Structural dip section $C^{\prime}$, Colorado Fairway. . . . . . . . . 157

126. Shale resistivity versus depth for nongeopressured well on section BB', Colorado County. . . . . . . . . . . . . . 160

127. Shale resistivity versus depth for well on cross section MM', Colorado

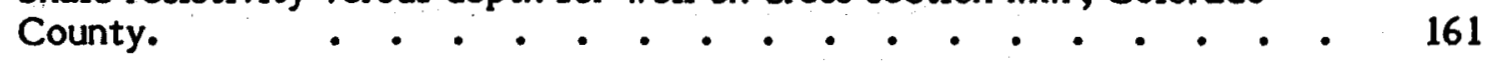

128. Shale resistivity versus depth for a nongeopressured well on cross section MM', Colorado County. . . . . . . . . . . . 162

129. Shale resistivity versus depth for a nongeopressured well, Colorado County. 163

130. Shale resistivity versus depth for a nongeopressured well, Colorado County. 164

131. Shale resistivity versus depth for a nongeopressured well, Colorado County. 165

132. Temperatures and geothermal gradients for 48 wells, Colorado County. . 166

133. Salinity profile for the type well on cross section MM' (fig. 136),

Colorado County. . . . . . . . . . . . . . . . 167

134. Porosity versus permeability for the type well on cross section MM', Colorado County. . . . . . . . . . . . . . . 168

135. Eagle Lake Prospect, type well site, and proposed test-well site, Colorado Fairway. . . . . . . . . . . . . . 171

136. Structural strike section MM', Colorado Fairway. • • • • • . . 172

137. Stratigraphic strike section MM', Colorado Fairway. . . . . . . 173

138. Location of wells and lines of section, Harris Fairway. . • • . . . 177

139. Stratigraphic dip section DD', Harris Fairway. . • . • • • • 178

140. Structural dip section DD', Harris Fairway. . . . . . . . . 179

141. Structural dip section EE', Harris Fairway. . . . . . . . . . 180 
142. Structural dip section HH',Harr is Fairway. - . • . - . . . . 181

143. Bottom-hole shut-in pressures for 23 wells located in Harris County. . . 182

144. Shale resistivity versus depth for a nongeopressured well on cross section DD', Waller County. . . . . . . . . . . . 183

\begin{tabular}{l} 
145. Top of geopressure and geopressure gradients for well on cross \\
section DD', Waller County. \\
\hline
\end{tabular}

146. Shale resistivity versus depth for a nongeopressured well on cross section EE', Grimes County. . . . . . . . . . . . . 185

147. Top of geopressure and geopressure gradients for well on cross section EE', Harr is County. . • . . . . . . . . . . . 186

148. Shale resistivity versus depth for a nongeopressured well on cross

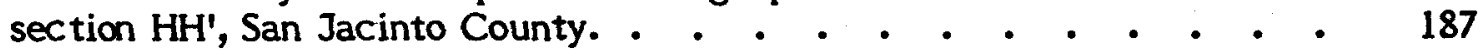

149. Shale resistivity versus depth for a well on cross section $\mathrm{HH}^{\prime}$, Montgomery County. $\quad . \quad \cdot$. . . . . . . . . . . . 188

150. Top of geopressure and geopressure gradients for well on cross section HH', Liberty County. • • • • • • • • • . . . . 189

151. Temperatures and geothermal gradients for the Harr is County Fairway area. 190

152. Temperatures and geothermal gradients for wells located on three fairway cross sections, Harr is County. - . . . . . . . . . 191

153. Salinity versus depth for 14 wells, Harr is County Fairway area. . • . . 192

\section{TABLES}

1. Summary of the physical characteristics of the six geopressured geothermal fairways. 


\section{INTRODUCTION}

Areas with the potential for containing geopressured geothermal fluids in economic quantities (geothermal fairways) occur in the Wilcox Group of Texas where the gulfward-dipping sandstone/shale wedge thickens abruptly across a complex growthfault system.

This regional study of the distribution of sandstone within the Wilcox Group (fig. 1) is part of a much broader investigation aimed at assessing the potential for producing geothermal energy from the deep subsurface geopressured zone of onshore Tertiary strata along the Texas Gulf Coast (Dorfman and Deller, eds., 1975, 1976). The objective of the study is to identify areas along the Wilcox trend in Texas most favorable for testing this potential resource. An ideal geopressured geothermal reservoir should have $5 \mathrm{~km}^{3}\left(3 \mathrm{mi}^{3}\right)$ of sandstone reservoir, fluid temperature greater than $149^{\circ} \mathrm{C}\left(300^{\circ} \mathrm{F}\right)$, and permeability of more than $20 \times 10^{-3} \mu \mathrm{m}^{2}(20 \mathrm{md})$.

Reports summarizing similar regional assessments of the Frio Formation and of a prospective test-well site have been published by the Bureau of Economic Geology, The University of Texas at Austin (Bebout, Dorfman, and Agagu, 1975; Bebout, Agagu, and Dorfman, 1975; Bebout, Loucks, Bosch, and Dorfman, 1976; Bebout, Loucks, and Gregory, 1978). The geothermal potential of the Vicksburg Formation was summarized by Loucks (1978). Funding for the entire Wilcox geopressured geothermal assessment program has been provided by the Division of Geothermal Energy, U. S. Department of Energy.

The Wilcox and Midway Groups, Lower Eocene, comprise the oldest thick sandstone/shale sequence within the Gulf Coast Tertiary System. Wilcox sandstones and shales crop out in a 16 to $32 \mathrm{~km}$ (10 to $20 \mathrm{mi}$ ) wide band that is subparallel to and 160 to $320 \mathrm{~km}$ ( 100 to $200 \mathrm{mi}$ ) inland from the present-day coastline (fig. 2). From the outcrop, the Wilcox dips coastward into the subsurface. It is one of at least eight thick wedges of Tertiary sandstone/shale (Hardin and Hardin, 1961). Sediments within the updip portion of the wedges were deposited primarily by fluvial processes. Downdip, the sediments that were transported across the Wilcox fluvial plain were deposited in huge deltaic systems; some deltaic sediments were reworked and transported along shore by marine processes where they were redeposited on barrier bars and strandplains. An understanding of the environmental setting of the Wilcox was developed almost 40 years ago by Deussen and Owen (1939) and has been improved by Culbertson (1940), Echols and Malkin (1948), and Hargis (1962) and demonstrated most recently by Fisher and McGowen (1967). 
Growth faults developed at the shorelines of several of the larger delta lobes where thick wedges of sand and mud were deposited on unconsolidated offshore mud of the previous wedge (fig. 3). During burial, subsidence and offset along these faults resulted in the isolation of thick sandstone and shale sequences which prevented lateral escape of pore fluids during subsequent compaction resulting from loading. Vertical escape of pore fluids was prevented by low vertical permeability of superposed shales. Limited fluid circulation within these growth-faulted blocks is responsible for the downward increase in pressure gradient from a normal hydrostatic pressure of $10.5 \mathrm{kPa} / \mathrm{m}$ to between 15.8 and $22.6 \mathrm{kPa} / \mathrm{m}(0.465 \mathrm{psi} / \mathrm{ft}$ to between 0.7 and $1.0 \mathrm{psi} / \mathrm{ft}$ ) and for an increase in temperature gradient from a normal $1.8^{\circ} \mathrm{C} / 100 \mathrm{~m}$ $\left(1.0^{\circ} \mathrm{F} / 100 \mathrm{ft}\right)$ to between 2.7 and $3.6^{\circ} \mathrm{C} / 100 \mathrm{~m}\left(1.5\right.$ and $\left.2.0^{\circ} \mathrm{F} / 100 \mathrm{ft}\right)$. This faulted, downdip section of the Wilcox Group, which exhibits a high pressure gradient and temperature exceeding $149^{\circ} \mathrm{C}\left(300^{\circ} \mathrm{F}\right)$, comprises the Wilcox geothermal corridor (fig. 2). 


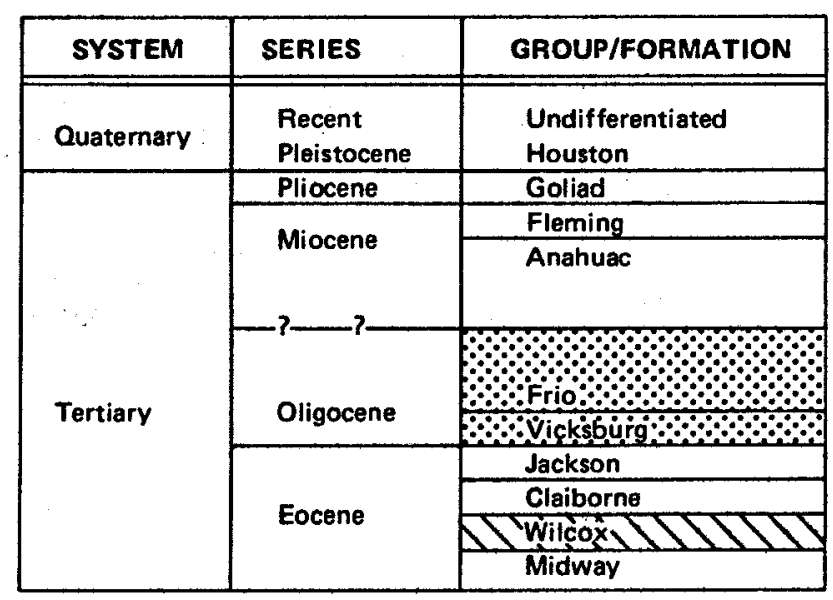

Figure 1. Tertiary formations, Gulf Coast of Texas. The Wilcox Group, the subject of this geothermal report, is shown by the diagonal pattern; the geothermal potential of the Frio and Vicksburg Formations, shown by the dot pattern, has been reviewed in other Bureau of Economic Geology reports (Bebout and others, 1975a, 1975b, 1976, 1978; Loucks, 1978). 


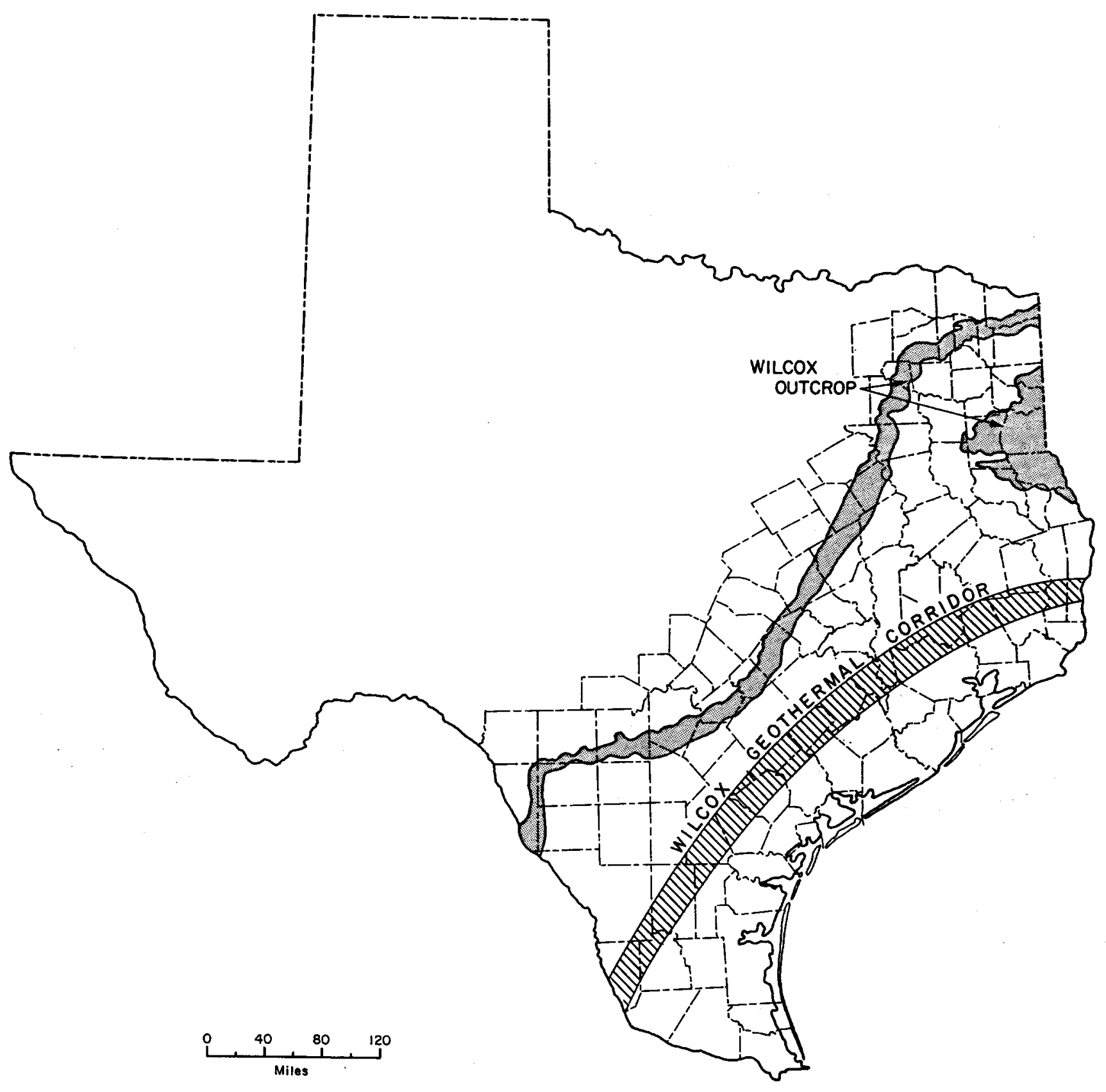

Figure 2. Wilcox geothermal corridor. 


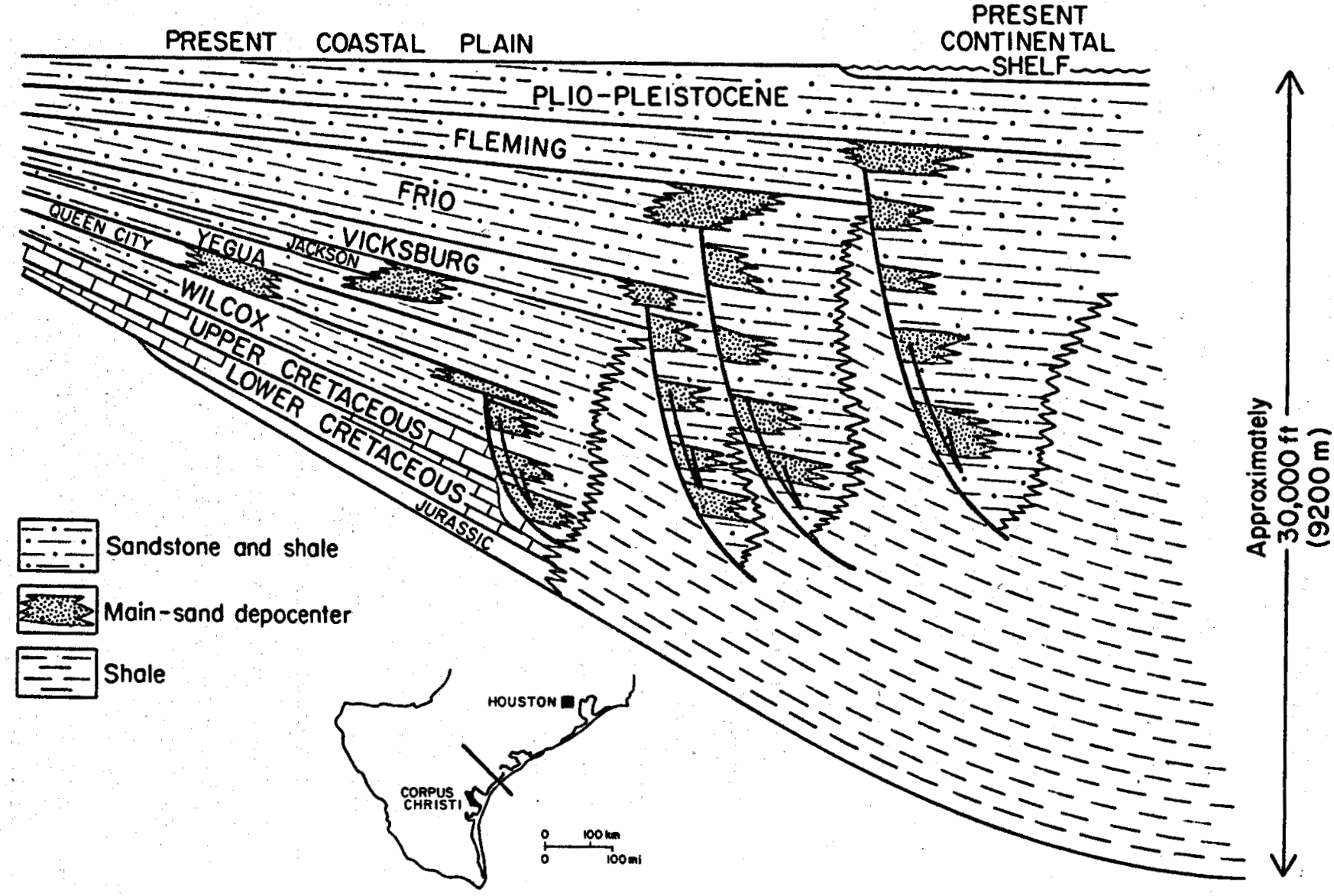

Figure 3. Depositional/structural style of the Tertiary along the Texas Gulf Coast. 
Regional and site-specific geological and engineering studies of the Wilcox Group of Texas have resulted in the selection of geopressured geothermal prospects in the Cuero area, De Witt Fairway, and Eagle Lake area, Colorado Fairway.

Areas with the potential for containing geopressured geothermal fluids in economic quantities occur in the Wilcox Group where the gulfward-dipping sandstone/ shale wedge thickens abruptly across a complex growth-fault system. As a result of the contemporaneous structure, the Wilcox is less than $600 \mathrm{~m}(2,000 \mathrm{ft})$ thick updip near the outcrop and more than $2,400 \mathrm{~m}(8,000 \mathrm{ft})$ thick downdip deeper than 3,000 $\mathrm{m}$ $(10,000 \mathrm{ft})$. The Wilcox is divided into three parts--the sandstone-rich upper and lower parts, which represent two major progradational cycles, and the shale-rich middle part, which represents a major transgression. In the lower Wilcox, thick sandstone and shale sequences occur in lobate patterns along the Middle and Upper Texas Gulf Coast; in the upper Wilcox, on the other hand, similar thick deltaic sandstones and shales occur along the Lower Texas Gulf Coast.

The objective of this study is to identify areas along the Wilcox trend favorable for testing the potential for producing large quantities of hot water from the geopressured zone in order to separate methane from solution and to produce electrical energy from heat. An ideal geopressured geothermal reservoir should have $5 \mathrm{~km}^{3}\left(3 \mathrm{mi}^{3}\right)$ of sandstone reservoir, fluid temperature greater than $149^{\circ} \mathrm{C}\left(300^{\circ} \mathrm{F}\right)$, and permeability of more than $20 \times 10^{-3} \mu \mathrm{m}(20 \mathrm{md})$.

The top of geopressure occurs at depths of 2,400 to $3,000 \mathrm{~m}(8,000$ to $10,000 \mathrm{ft})$ where shale is dominant and at 3,400 to $4,000 \mathrm{~m}(11,000$ to $13,000 \mathrm{ft})$ where sandstone is dominant. Formation temperatures also vary within the Wilcox depending upon the position along dip, lithology, location of growth faults, and location along the Texas Gulf Coast, but temperatures higher than $149^{\circ} \mathrm{C}\left(300^{\circ} \mathrm{F}\right)$ generally occur at approximately 3,300 m (11,000 ft).

Six geothermal fairways have been delineated along the Texas Gulf Coast by combining the sandstone distribution and isotherm maps--Zapata, Duval; Live Oak, De Witt, Colorado, and Harris. In these fairway areas sandstone-rich sections occur with formation temperature greater than $149^{\circ} \mathrm{C}\left(300^{\circ} \mathrm{F}\right)$. Detailed studies have been conducted in these fairways in order to identify the most favorable areas for drilling geothermal test wells.

The Zapata, Duval, and Live Oak Fairways (table 1) contain thick, laterally extensive sandstone units in the upper Wilcox. The sections in which these sandstones occur are extremely thick as a result of contemporaneous subsidence along large 
growth faults. Fluid temperatures are greater than $149^{\circ} \mathrm{C}\left(300^{\circ} \mathrm{F}\right)$ in the Zapata and Duval Fairways but lower in the Live Oak Fairway. Core analyses indicate that porosity and permeability are low in these deep sandstone units and, for this reason, these fairways are not at present being considered as potential for geopressured geothermal test-well sites.

The De Witt Fairway is considered the prime area for a geopressured geothermal test in the Wilcox in Texas. The fairway is located in the complex growth-faulted portion of the lower Wilcox trend just downdip of the underlying Lower Cretaceous Stuart City Trend. The Cuero Prospect, within the De Witt Fairway, contains more than $170 \mathrm{~m}(550 \mathrm{ft})$ of geopressured sandstone, which is expected to extend over an area of approximately $36 \mathrm{~km}^{2}\left(14 \mathrm{mi}^{2}\right)$. The prospective sandstones deposited in a wide variety of deltaic environments occur at the tops of at least eight coarseningupward cycles; progressively shallower cycles contain sandstones deposited in more proximal deltaic environments. Fluid temperatures of $149^{\circ} \mathrm{C}\left(300^{\circ} \mathrm{F}\right)$ have been recorded within the reservoir section. Core analyses from the fairway indicate that the permeabilities range from less than $2.1 \times 10^{-3}$ to more than $100 \times 10^{-3} \mu \mathrm{m}^{2}(2.1$ to more than $100 \mathrm{md}$ ). The highest permeability occurs at the top of the prospective reservoir section where the most proximal deltaic facies occur.

In the Colorado Fairway 370 to $490 \mathrm{~m}(1,200$ to $1,600 \mathrm{ft})$ of sandstone with fluid temperature greater than $149^{\circ} \mathrm{C}\left(300^{\circ} \mathrm{F}\right)$ occur in the lower Wilcox Group in an area that is considered prospective for the location of a geopressured geothermal test. Few growth faults have been recognized in the fairway area, perhaps in part because of lack of adequate deep well control. Approximately $380 \mathrm{~m}(1,240 \mathrm{ft})$ of sandstone are expected in the area of the proposed Eagle Lake test-well site. Pressure gradients in the Colorado Fairway are generally low, and many wells in the area do not penetrate the top of geopressure. Most permeabilities are lower than $5 \times 10^{-3} \mu^{2}(5 \mathrm{md})$; but some range up to $545 \times 10^{-3}{\mu \mathrm{m}^{2}}^{2}(545 \mathrm{md})$. in thin, isolated sandstones. Although the Colorado Fairway is considered prospective as a potential geopressured geothermal test-well site, there is question as to the presence of adequate thickness of highpermeability zones.

The Harris Fairway contains a massive sandstone section with more than $610 \mathrm{~m}$ $(2,000 \mathrm{ft})$ of net sandstone in the lower Wilcox. Most of the lower Wilcox in the downdip part of the fairway is geopressured and has fluid temperatures greater than $149^{\circ} \mathrm{C}\left(300^{\circ} \mathrm{F}\right)$. However, most permeabilities are less than $5 \times 10^{-3} \mu \mathrm{m}^{2}(5 \mathrm{md})$, and many are less than $1 \times 10^{-3} \mu^{2}(1 \mathrm{md})$. Although the Harris Fairway contains by far the thickest sandstone section of all Wilcox fairways, it is not recommended for testing at present because of extremely low permeability recordings. 
Table 1. Summary of the physical characteristics of the six geopressured geothermal fairways.
ZAPATA
DUVAL
LIVE OAK
DE WITT
COLORADO
HARRIS

PART OF

WILCOX

Upper

Upper

Upper

Lower

Lower

Lower

DEPTH
TO TOP OF
PROSPECTIVE

$2,930 \mathrm{~m}(9,600 \mathrm{ft})$

3,355 m (11,000 ft)

2,805 m (9,200 ft)

$3,200 \mathrm{~m}(10,490 \mathrm{tt})$

$3,660 \mathrm{~m}(12,000 \mathrm{ft})$

$3,355 \mathrm{~m}(11,000 \mathrm{ft})$

$3,250 \mathrm{~m}$ (10 $10,660 \mathrm{ft})$

$3,340 \mathrm{~m}(10,960 \mathrm{ft})$

$3,475 \mathrm{~m}$ (111,400 ft)

$3,810 \mathrm{~m}(12,500 \mathrm{ft})$

SANDSTONE

THICKNESS

OF

$85 \mathrm{~m}(280 \mathrm{ft})$ to

$190 \mathrm{~m}(620 \mathrm{ft})$

More than

$185 \mathrm{~m}(600 \mathrm{ft})$

More than

SANDSTONE

$185 \mathrm{~m}(600 \mathrm{ft})$

$170 m(550 \mathrm{ft})$

$490 \mathrm{~m}(1,600 \mathrm{ft})$

More than $610 \mathrm{~m}(2,000 \mathrm{ft})$

TOP OF

GEOPRESSURE

\section{$3,265 \mathrm{~m}$}

$(10,700 \mathrm{ft})$

\section{$3,050 \mathrm{~m}$}

\section{$3,035 \mathrm{~m}$}

$3,050 \mathrm{~m}$

$15.8 \mathrm{kPa} / \mathrm{m}$
$(0.7 \mathrm{psi} / \mathrm{ft})$

$(10,000 \mathrm{ft})$

$(9,950 \mathrm{ft})$

$(10,000 \mathrm{ft})$

$3,660 \mathrm{~m}$

$(12,000 \mathrm{ft})$

$3,520 \mathrm{~m}$

$(11,550 \mathrm{ft})$ TEMPERATURE $\begin{gathered}149^{\circ} \mathrm{C}\left(300^{\circ} \mathrm{F}\right) \text { at } \\ 3,475 \mathrm{~m}(11,400 \mathrm{ft})\end{gathered}$

$149^{\circ} \mathrm{C}\left(300^{\circ} \mathrm{F}\right)$ at $\quad 149^{\circ} \mathrm{C}\left(300^{\circ} \mathrm{F}\right)$ at $\quad 149^{\circ} \mathrm{C}\left(300^{\circ} \mathrm{F}\right)$ at

$3,280 \mathrm{~m}(10,750 \mathrm{ft}) \quad 3,355 \mathrm{~m}(11,000 \mathrm{ft}) \quad 3,310 \mathrm{~m}(10,850 \mathrm{ft})$

$149^{\circ} \mathrm{C}\left(300^{\circ} \mathrm{F}\right)$ at

$149^{\circ} \mathrm{C}\left(300^{\circ} \mathrm{F}\right)$ at

POROSITY

17 to $22 \%$

7 to $14 \%$

16 to $24 \%$

6 to $25 \%$

4 to $19 \%$

Most less than

$5 \times 10^{-3} \mu \mathrm{m}^{2}(5 \mathrm{md})$

locally up to $545 \times 10^{-3} \mu^{2}$ (545 md)
Eagle Lake

Prospect
None

Low Permeability
PROSPECT
IDENTIFIED

\section{None}

Low Permeability
Cuero

Prospect

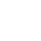
$242 \times 10^{-3} \mu^{2}$ (0.01 to $242 \mathrm{md}$ )
( 5 to $40 \mathrm{md}$ )
10 to $19 \mathrm{~mol}$
(0.1 to $44 \mathrm{md}$ )

and




\section{REGIONAL SETTING}

The Wilcox Group is less than $600 \mathrm{~m}(2,000 \mathrm{ft})$ thick updip near the outcrop and more than $2,400, m(8,000 \mathrm{ft})$ thick downdip at depths greater than $3,000 \mathrm{~m}(10,000 \mathrm{ft})$.

The Wilcox Group is composed of a thick wedge of sandstone and shale which crops out several hundred feet above sea level at its updip limit. More than $160 \mathrm{~km}$ (100 mi) downdip, the Wilcox is $3,000 \mathrm{~m}(10,000 \mathrm{ft})$ below sea level (figs. 4, 5). Regional dip averages $19 \mathrm{~m} / \mathrm{km}(100 \mathrm{ft} / \mathrm{mi})$. Where the Wilcox depocenter prograded gulfward of the underlying Lower Cretaceous Stuart City shelf margin (Edwards and Sligo Formations), a band of growth faults $32 \mathrm{~km}(20 \mathrm{mi})$ wide developed (fig. 6), indicating that the gulfward edge of the shelf controlled the location of the Wilcox growth faults. Sandstones and shales of the Wilcox thicken abruptly downdip of the Stuart City shelf margin (fig. 4, wells 7 to 8). The zone of steeper (closely spaced) contours on the structure and thickness maps (figs. 5,7 ) coincides with the location of the best developed growth faults.

The base of the Wilcox Group is transitional with the underlying marine Midway Group. The upper part of the Midway is believed by many to be a marine facies of the lowermost Wilcox fluvial and deltaic facies (Culbertson, 1940; Echols and Malkin, 1948; Johnston, 1977; Townsend, 1954). The top of the Wilcox Group is placed by us and by many others (Culbertson, 1940; Echols and Malkin, 1948; Fisher, 1969; and Murray, 1955) at the top of the Carrizo Sandstone. 


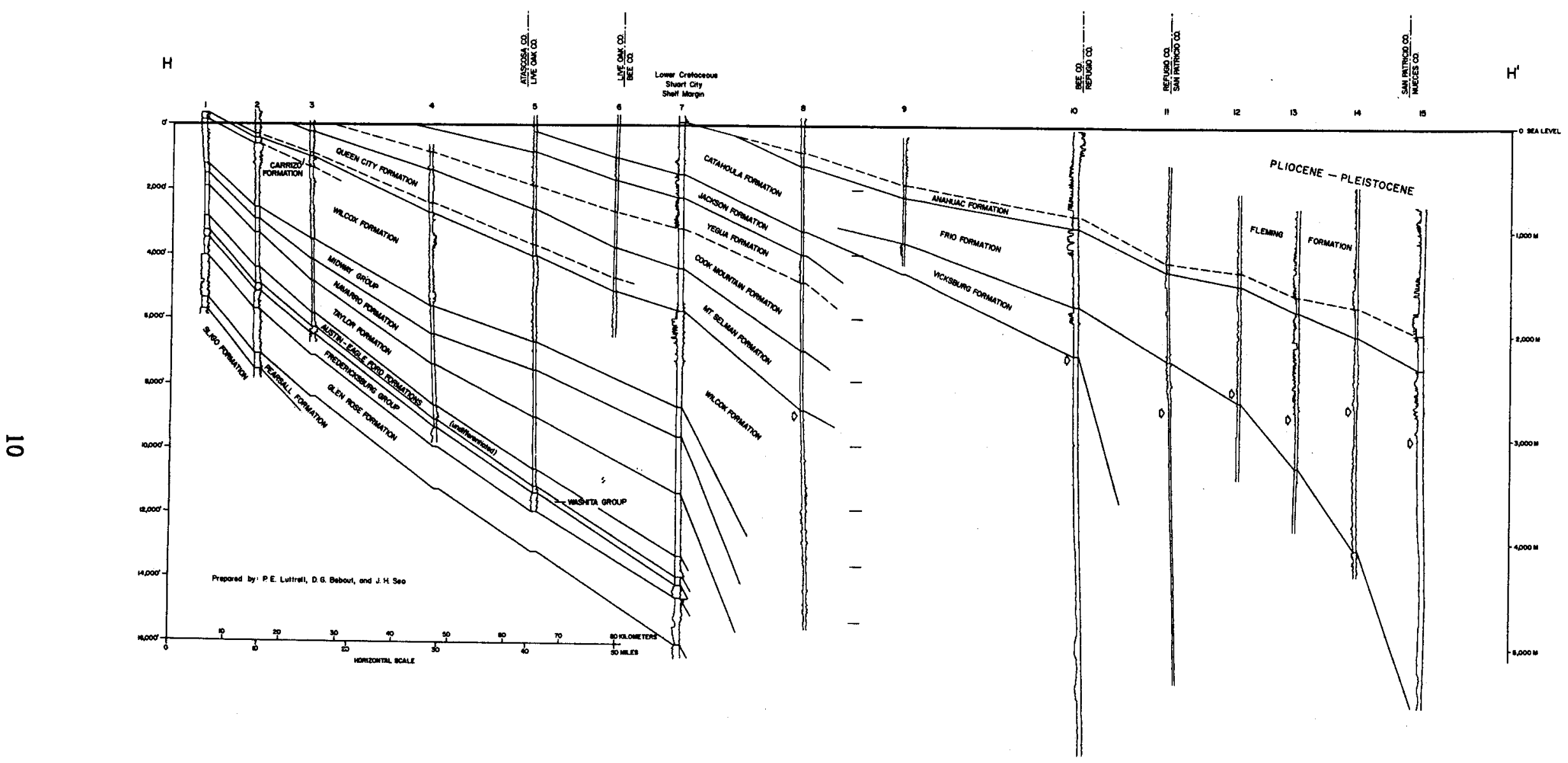

Figure 4. Regional dip section (Bebout, Luttrell, and Seo, 1975; section $\mathrm{HH}^{\prime}$ ). The Wilcox Group thickens abruptly just downdip of the Lower Cretaceous Stuart City shelf margin by means of a complex system of growth faults. 


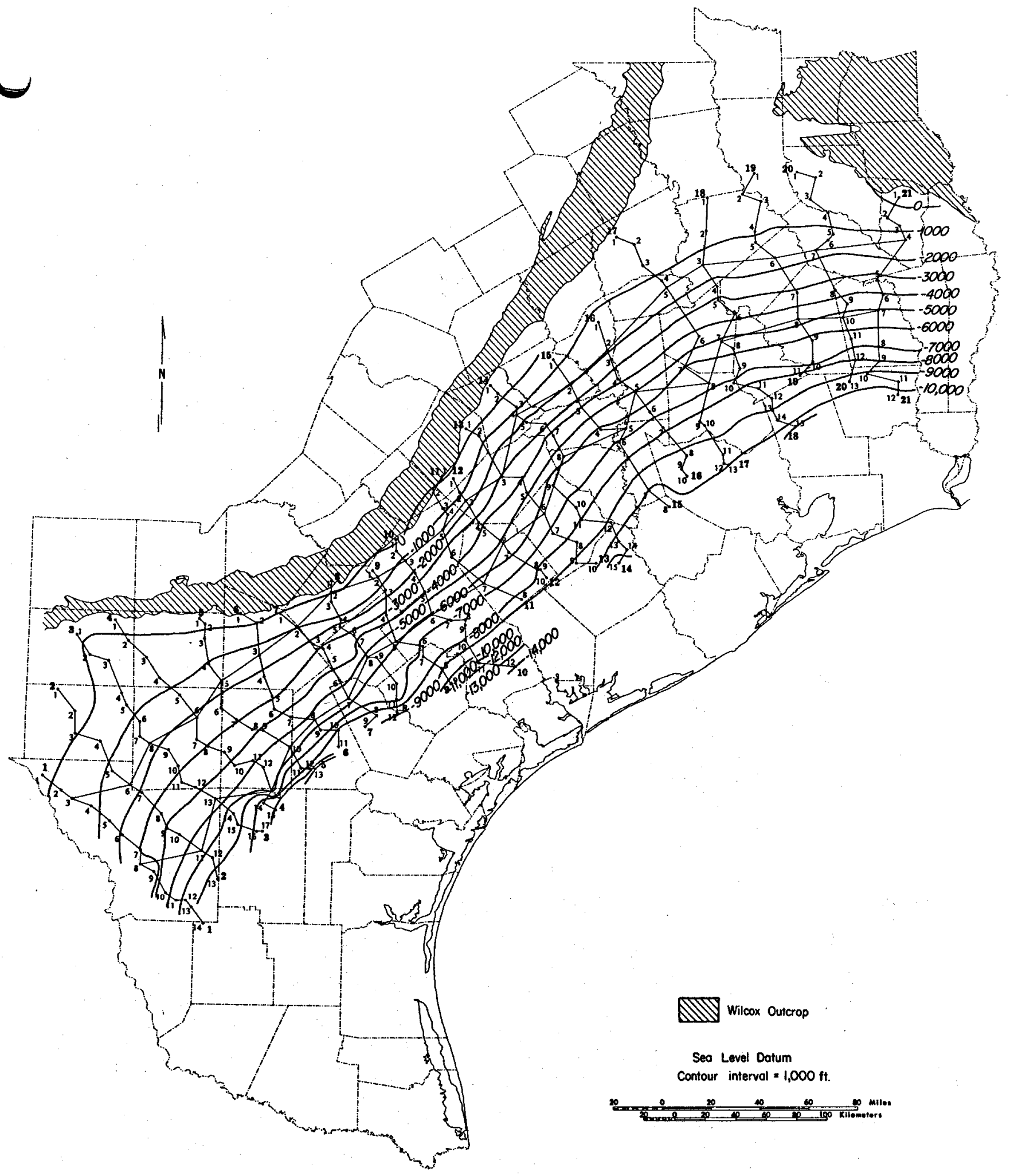

Figure 5. Structure on top of the Wilcox Group. 


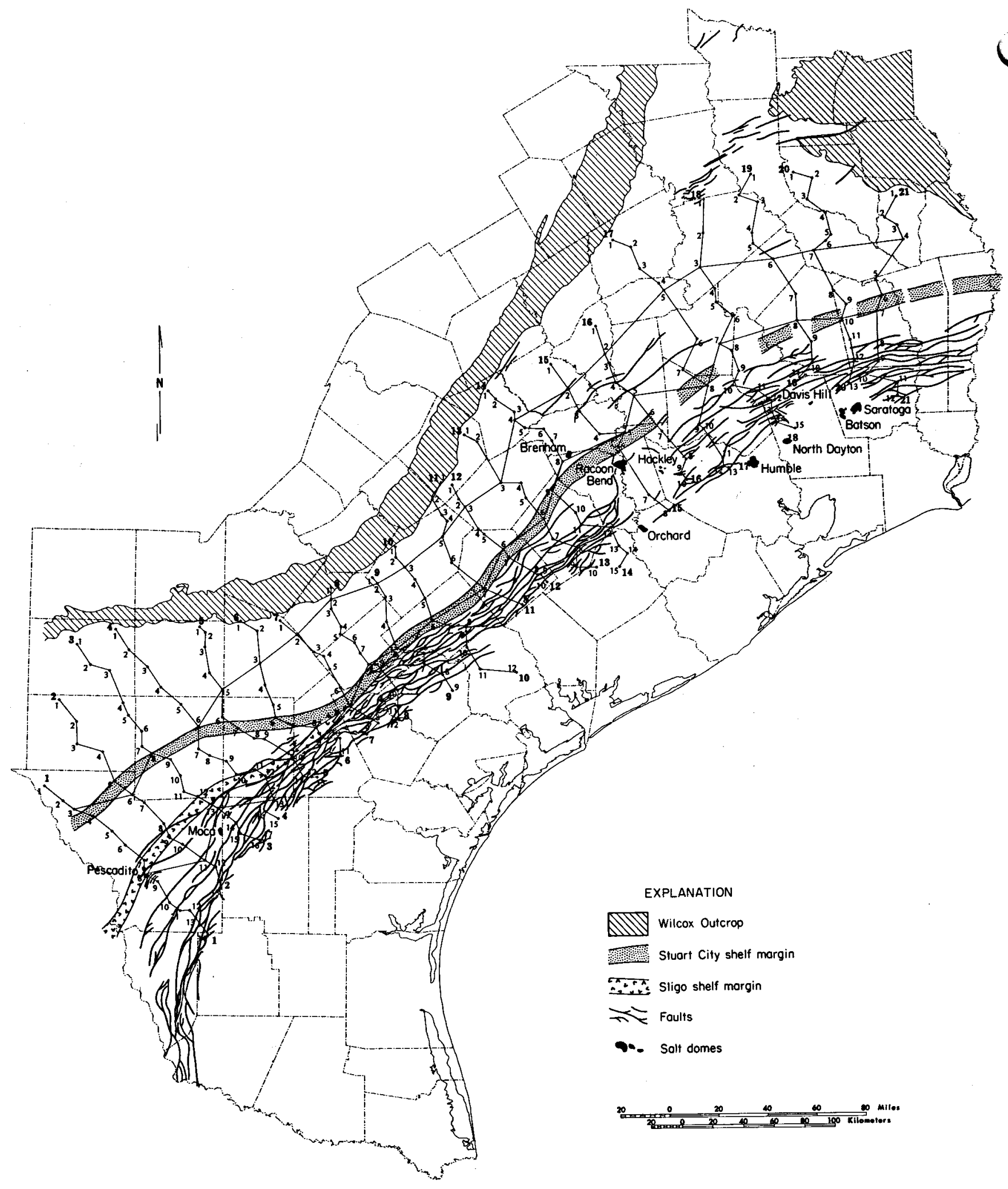

Figure 6. Faults in the Wilcox Group. Most of these faults are growth faults which were active during deposition of the Wilcox. Courtesy of Geomap Company, Houston, Texas. 


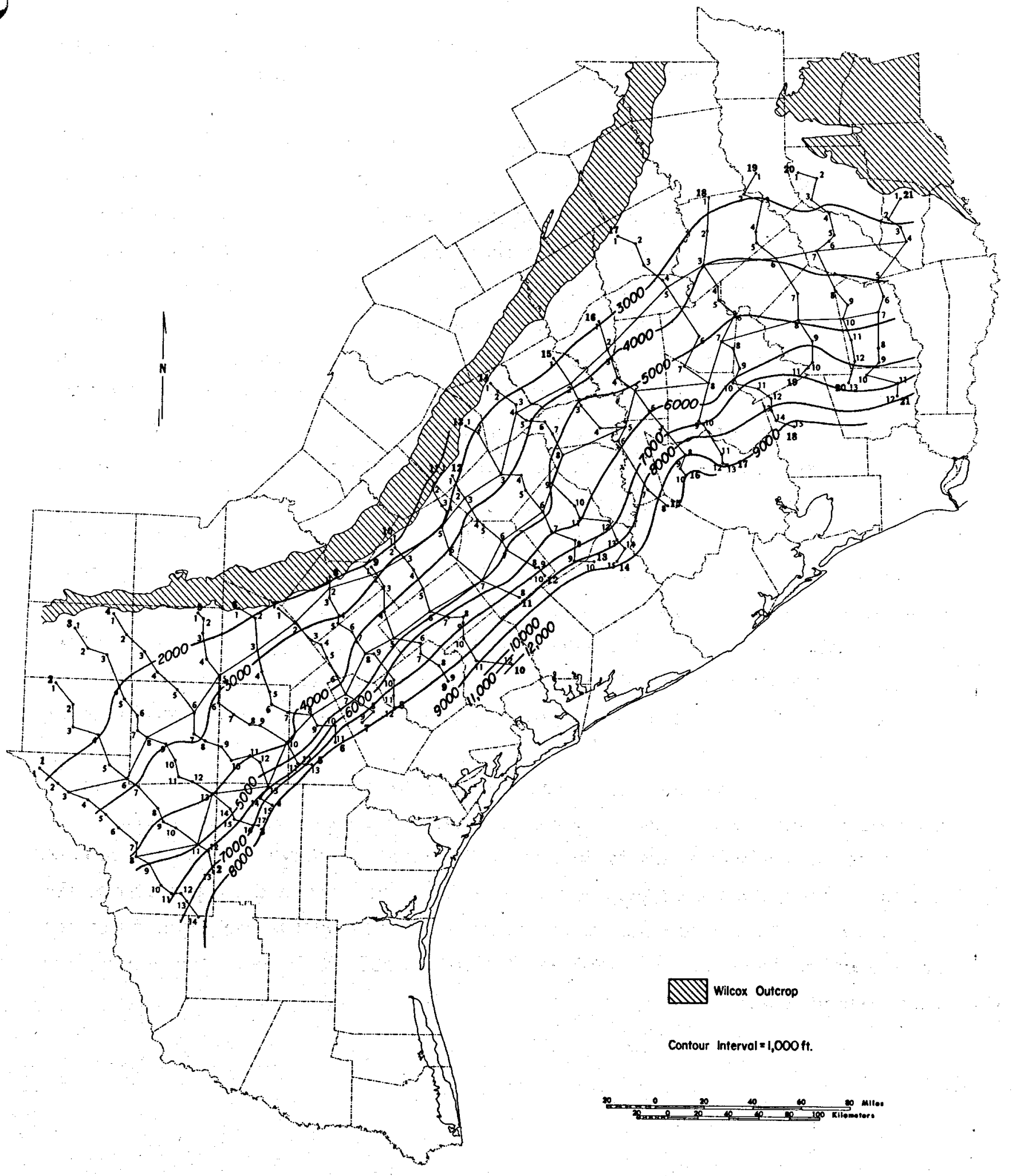

Figure 7. Total thickness of the Wilcox Group. 


\section{STRATIGRAPHIC SECTIONS}

The sandstone-rich upper and lower parts of the wilcox represent two major progradational cycles separated by shaley middle wilcox transgressive deposits.

Twenty-one regional stratigraphic dip sections, spaced 25 to $35 \mathrm{~km}$ (15 to $20 \mathrm{mi}$ ) apart, were constructed using electrical logs from wells located along the entire Texas Gulf Coast (fig. 8). On each well log, the top of the Wilcox and two regional markers have been identified (fig. 9); these markers were selected through the detailed correlations of closely spaced wells in the fairway areas discussed later in this report. The markers were then projected onto the regional cross sections and extended throughout the Wilcox trend. The lower regional marker corresponds to the top of the lower Wilcox of Fisher and McGowen (1967); the upper regional marker is at the base of the upper Wilcox of Fisher and McGowen. Maps showing the regional distribution of sandstone in the lower and upper Wilcox have been published by Fisher and McGowen (1967) and Fisher (1969), respectively.

The dip sections (figs. 10 to 30 ) include 10 to 15 wells each and extend from near the outcrop to the downdip limit of Wilcox sandstones or well control. Strike sections (figs. 31 and 32) were constructed to ensure correlation among dip sections. Datum for the sections is the top of the Wilcox Group. Growth faults present at the downdip end of the sections have been omitted so as not to obscure well-to-well correlation of sandstones. Data from these sections are supplemented by denser well control used by Fisher and McGowen (1967).

The top of geopressure (shallowest depth of pressure gradient of $15.8 \mathrm{kPa} / \mathrm{m}$, or $0.7 \mathrm{psi} / \mathrm{ft}$ ), marked by the black arrow on stratigraphic sections (figs. 10 to 32 ), occurs well beneath the base of the updip part of the Wilcox. Downdip, within the zone of growth faulting, the top of geopressure generally occurs within the upper part of the Wilcox Group. Subsurface fluid temperature of $149^{\circ} \mathrm{C}\left(300^{\circ} \mathrm{F}\right)$, also indicated on the cross sections, occurs 300 to $460 \mathrm{~m}(1,000$ to $1,500 \mathrm{ft})$ beneath the top of the geopressured zone. 


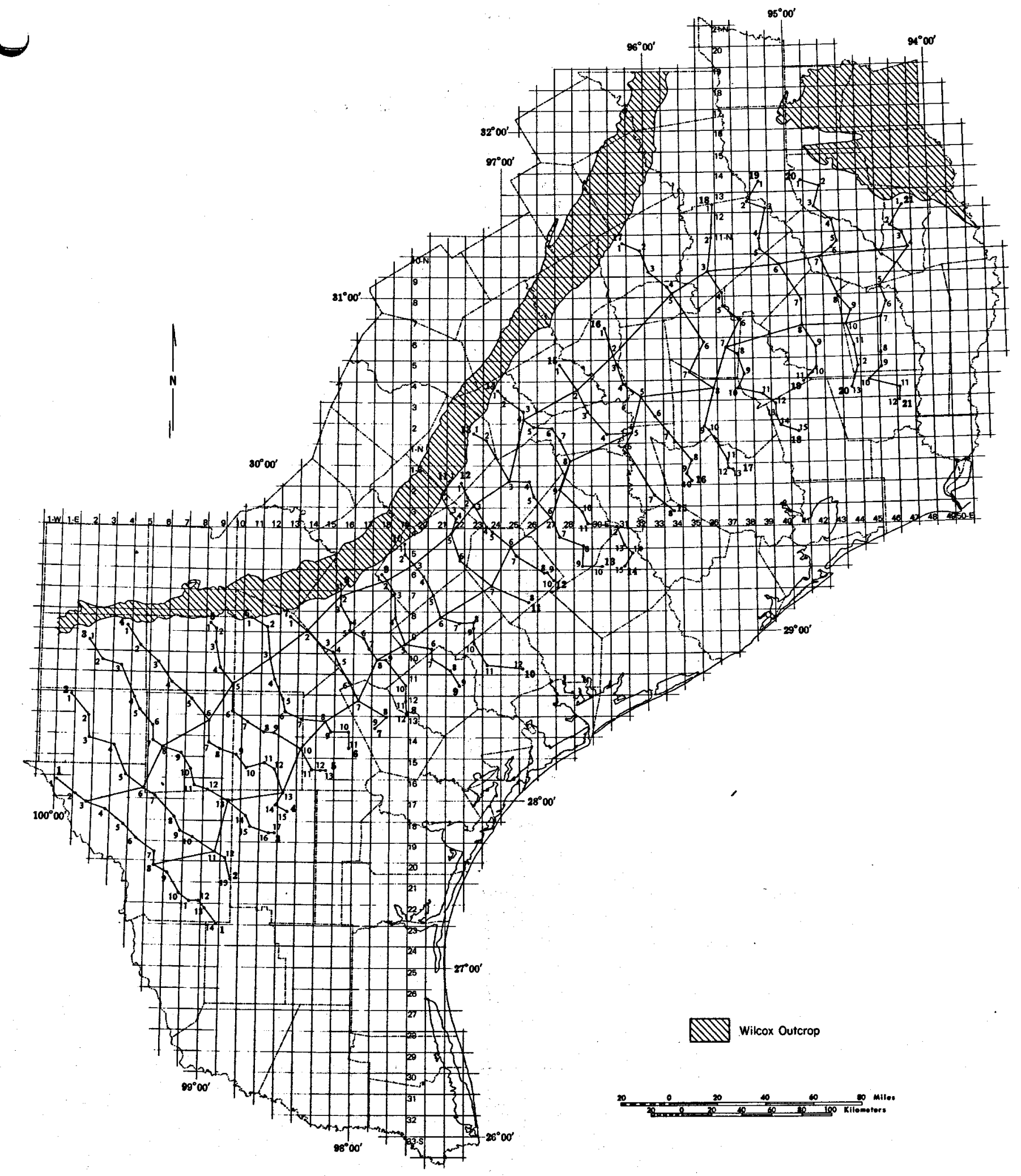

Figure 8. Well-log control and location of sections (figs. 10-32). Supplemental well data from Fisher and McGowen (1967) and Fisher (1969) are not shown. 


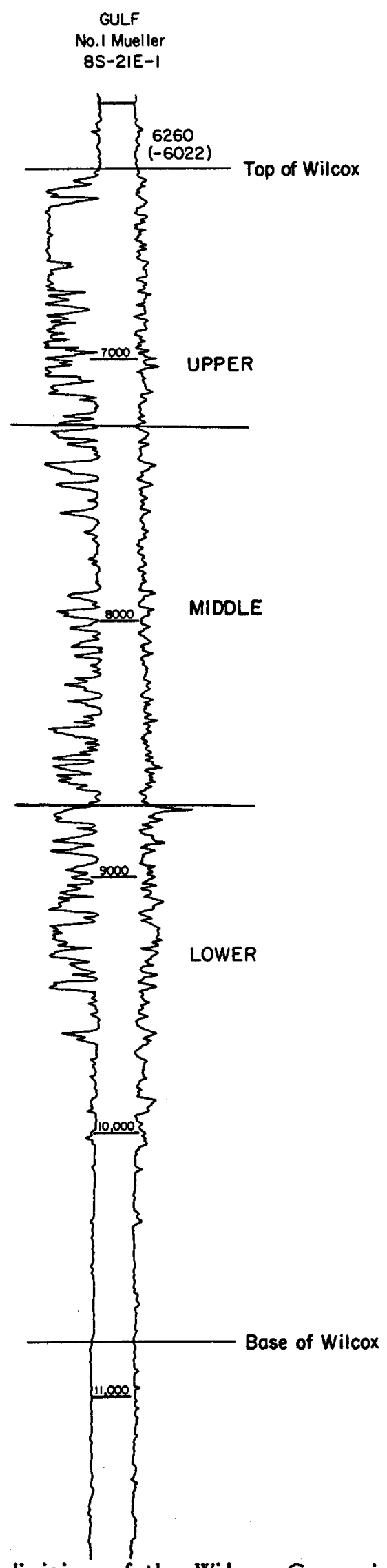

Figure 9. Electrical log showing division of the Wilcox Group into the sandstone-rich lower and upper parts, each of which represents a major progradational cycle, separated by middle Wilcox shales deposited during a marine transgression. 


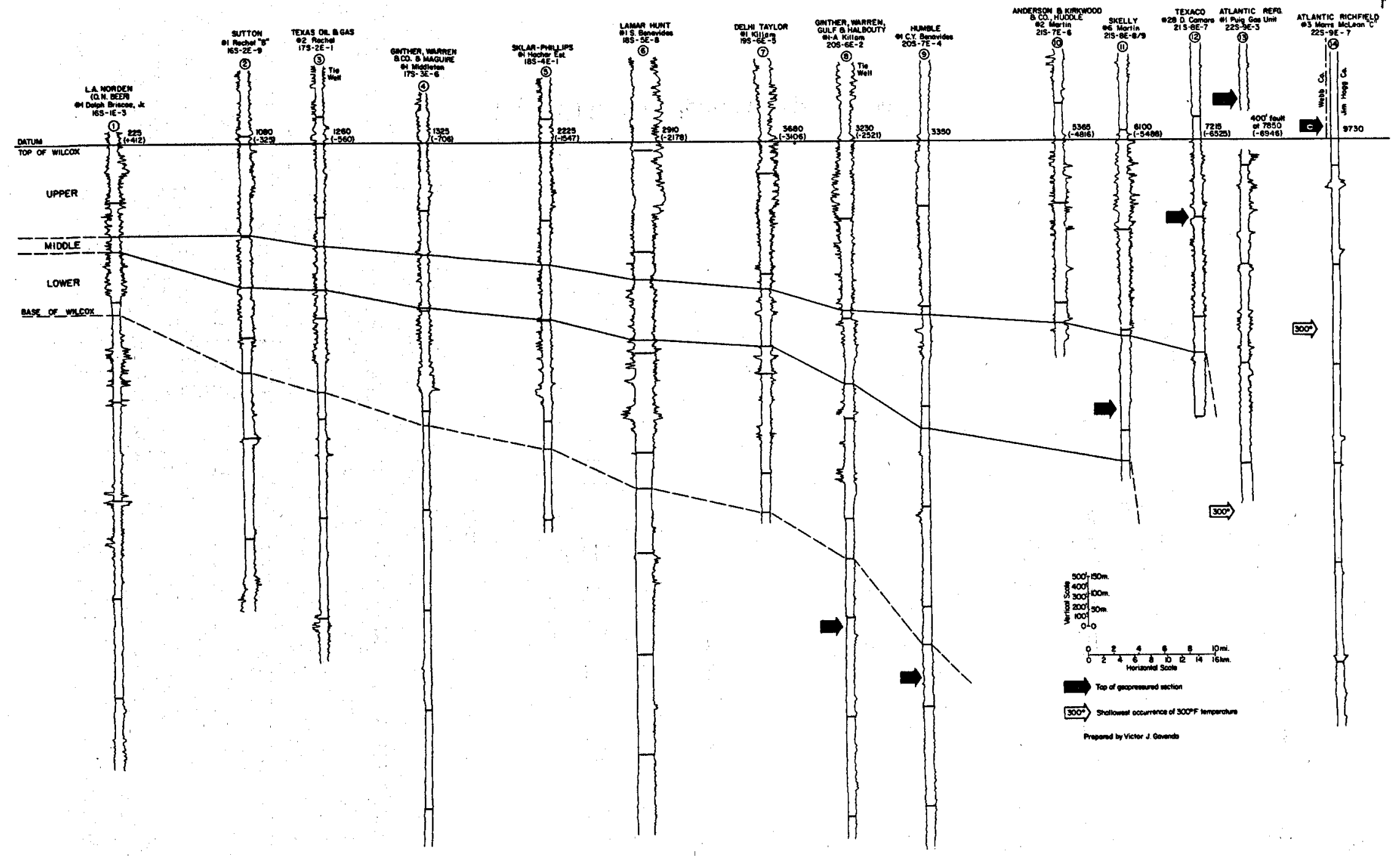

Figure 10. Stratigraphic dip section 1. The locations of this section and those that follow (figs. 11 to 32) are shown in figure 8. The datum for each section is the top of the Wilcox Group and the transition between the Wilcox and the underlying Midway is shown by the dashed line. The top of geopressure is shown by the black arrows and the approximate point at which $149^{\circ} \mathrm{C}\left(300^{\circ} \mathrm{F}\right)$ is reached is shown by the arrows labeled $300^{\circ} \mathrm{F}$. 
2

$\infty$

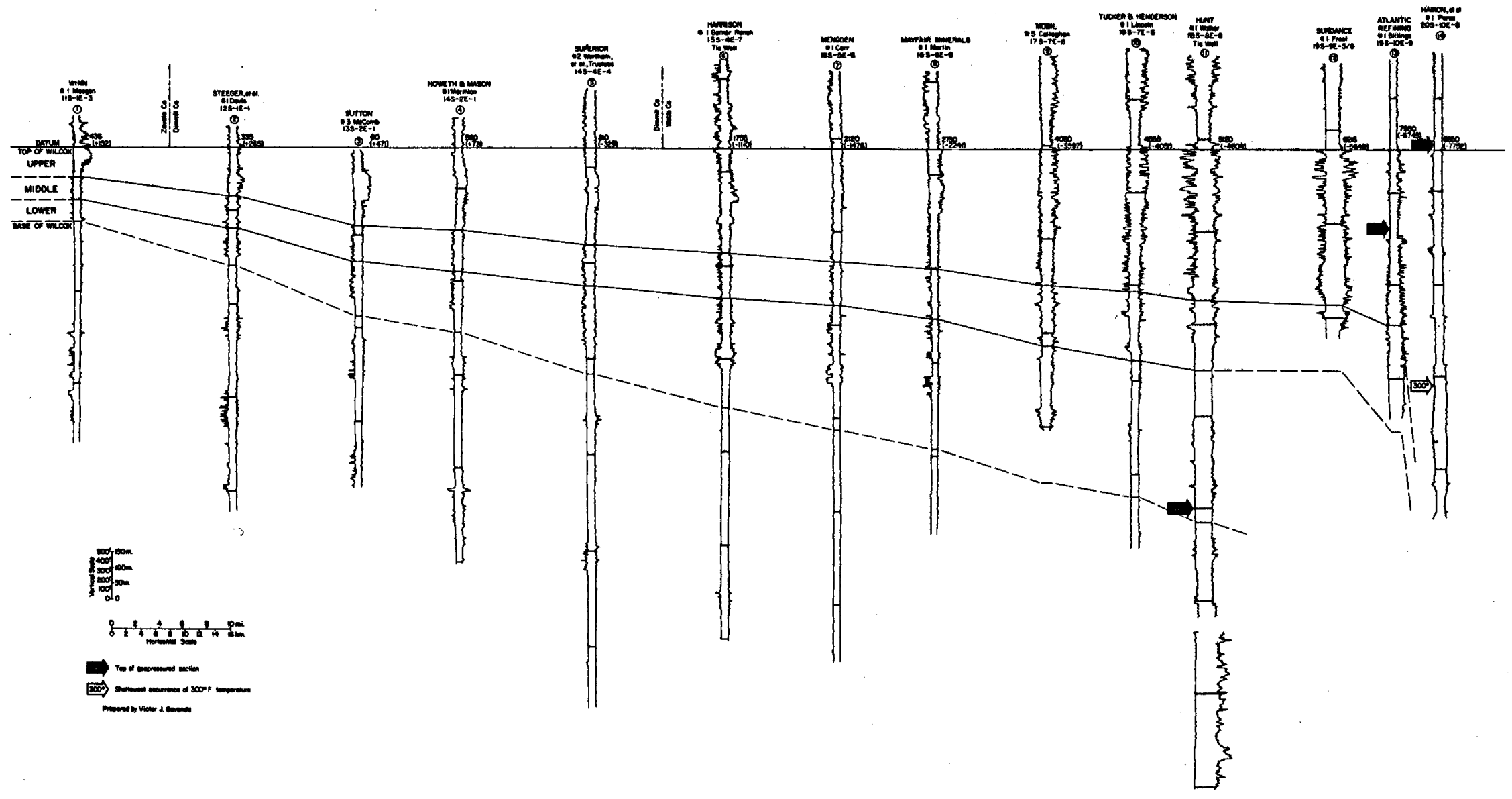

Figure 11. Stratigraphic dip section 2. 


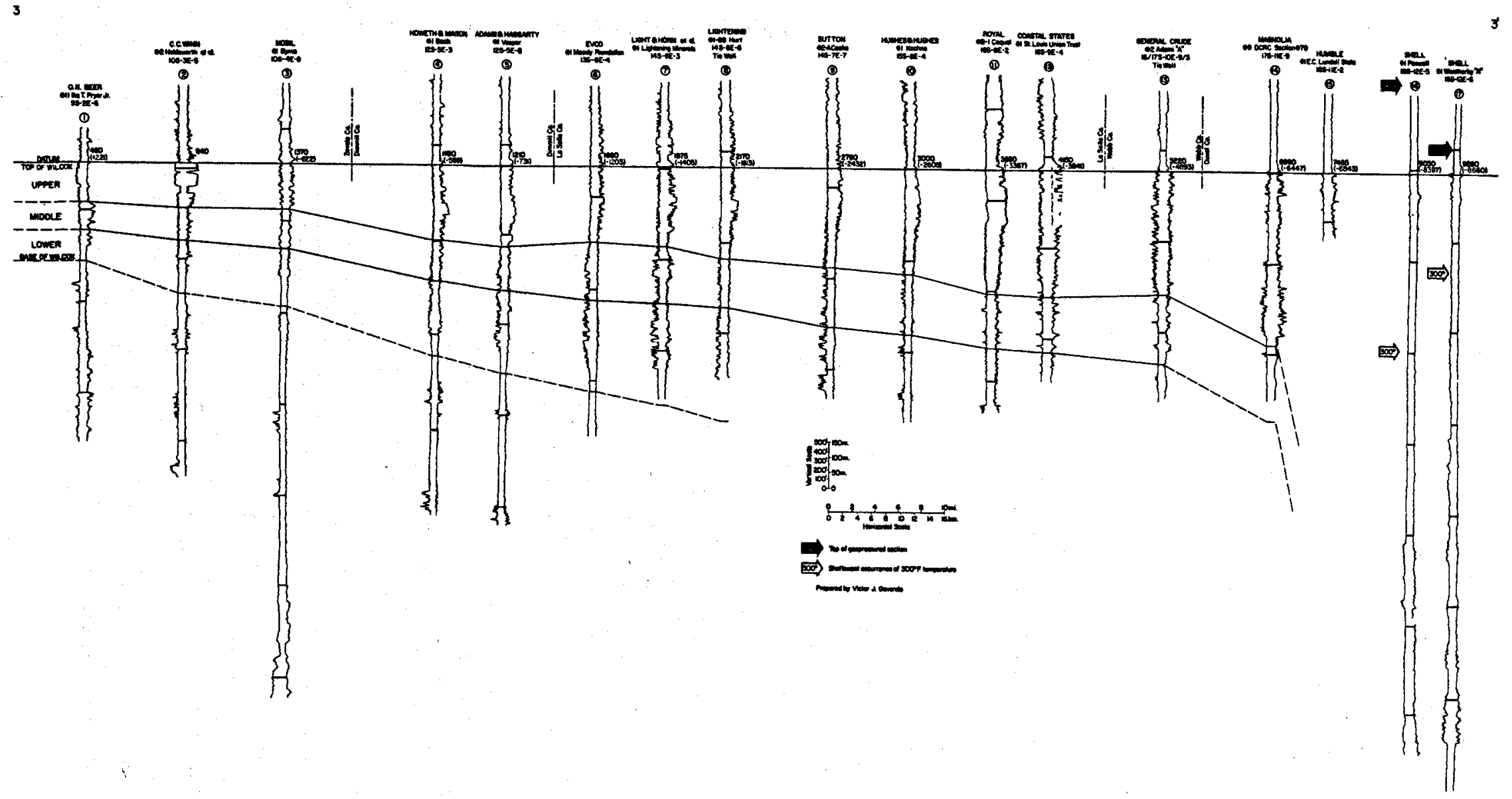

Figure 12. Stratigraphic dip section 3. 


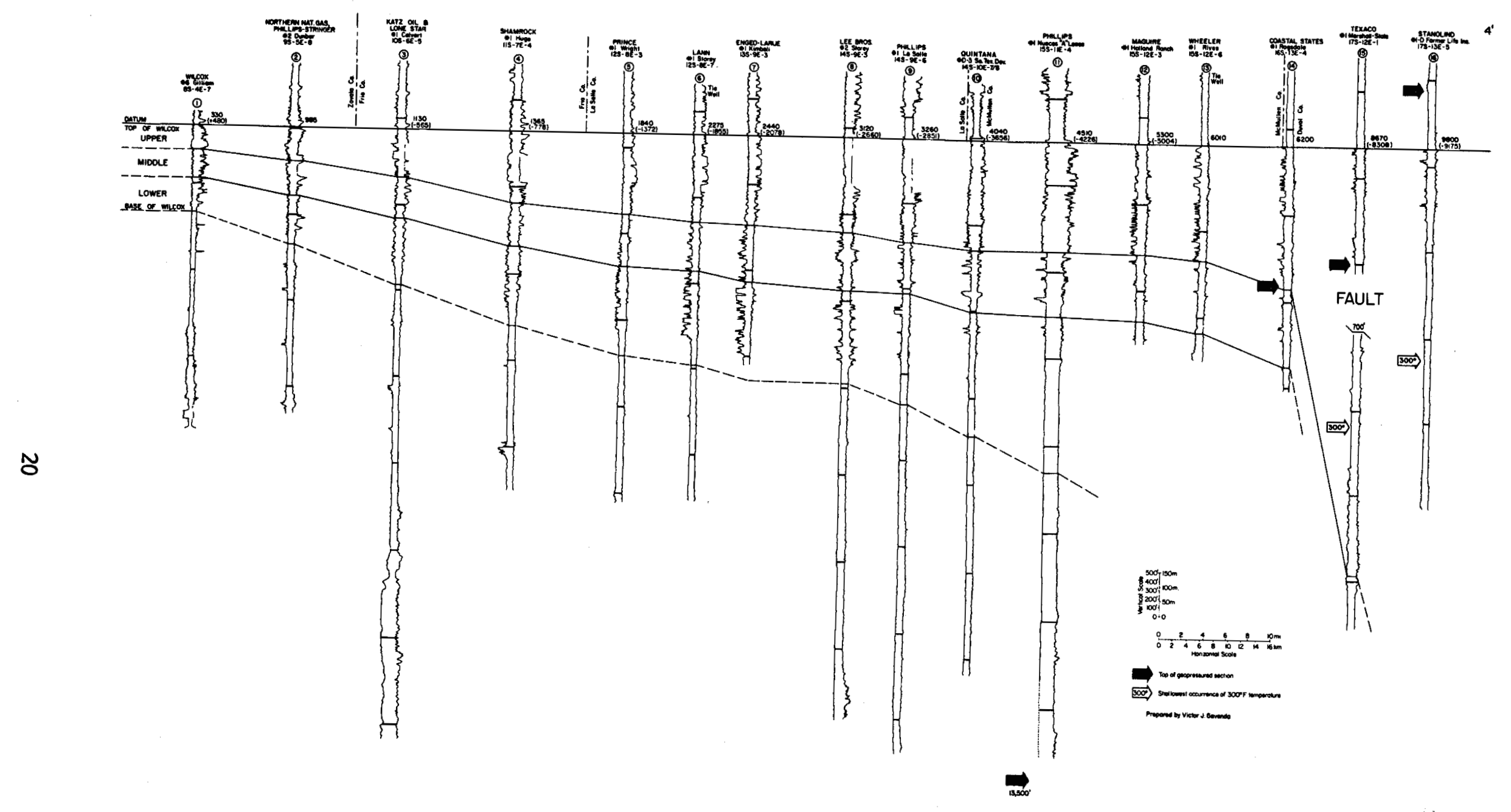

Figure 13. Stratigraphic dip section 4. 


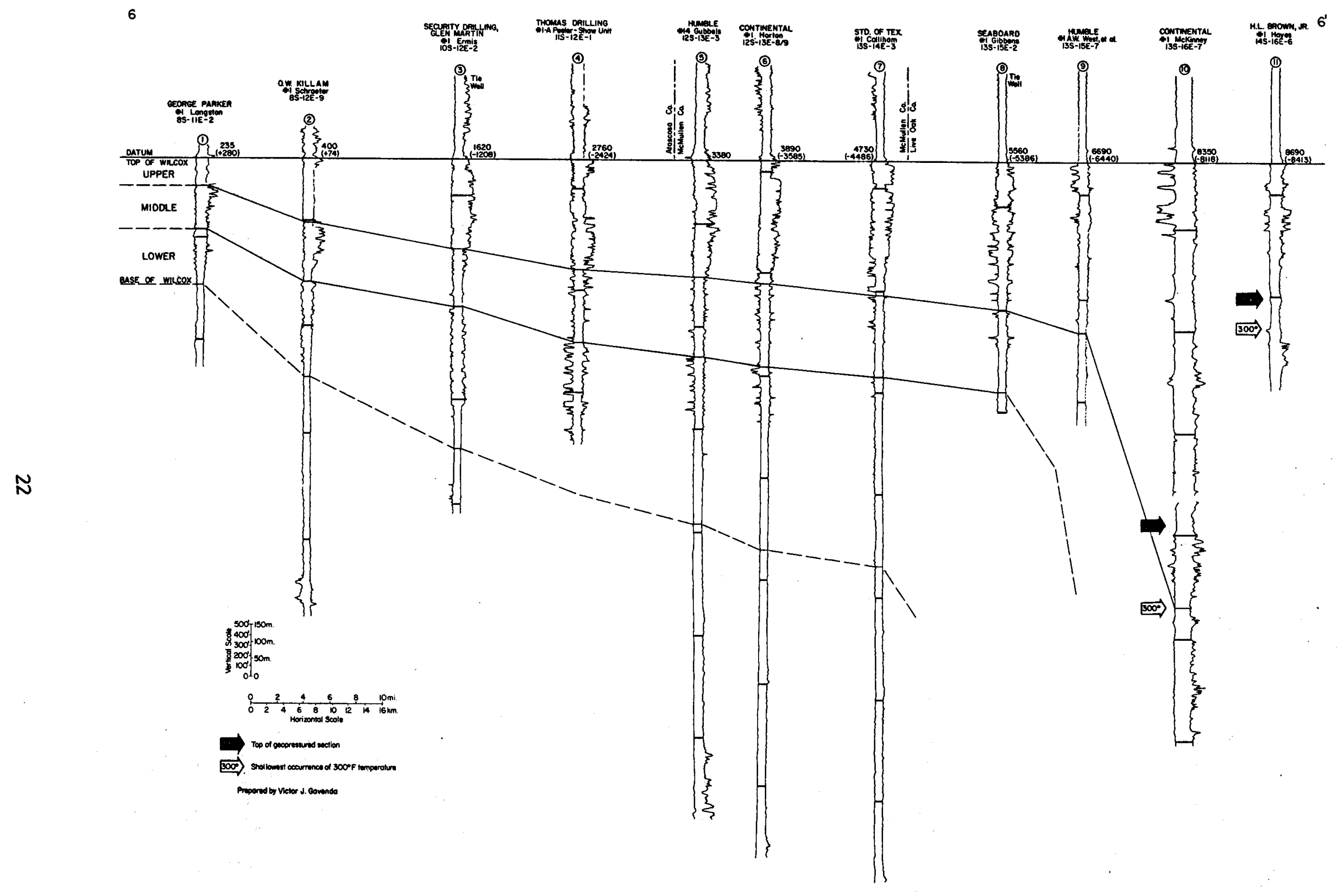

Figure 15. Stratigraphic dip section 6. 


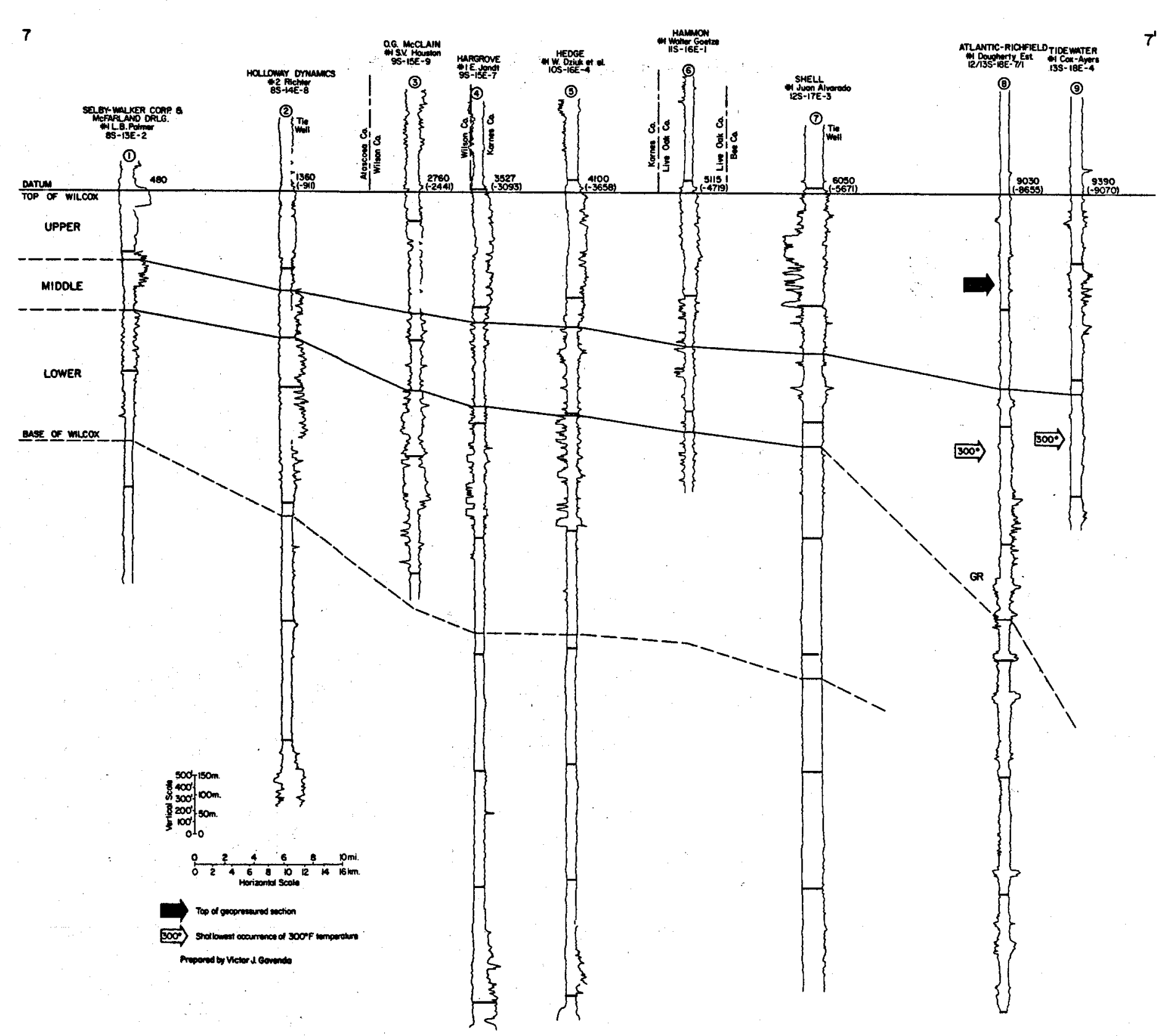

Figure 16. Stratigraphic dip section 7. 


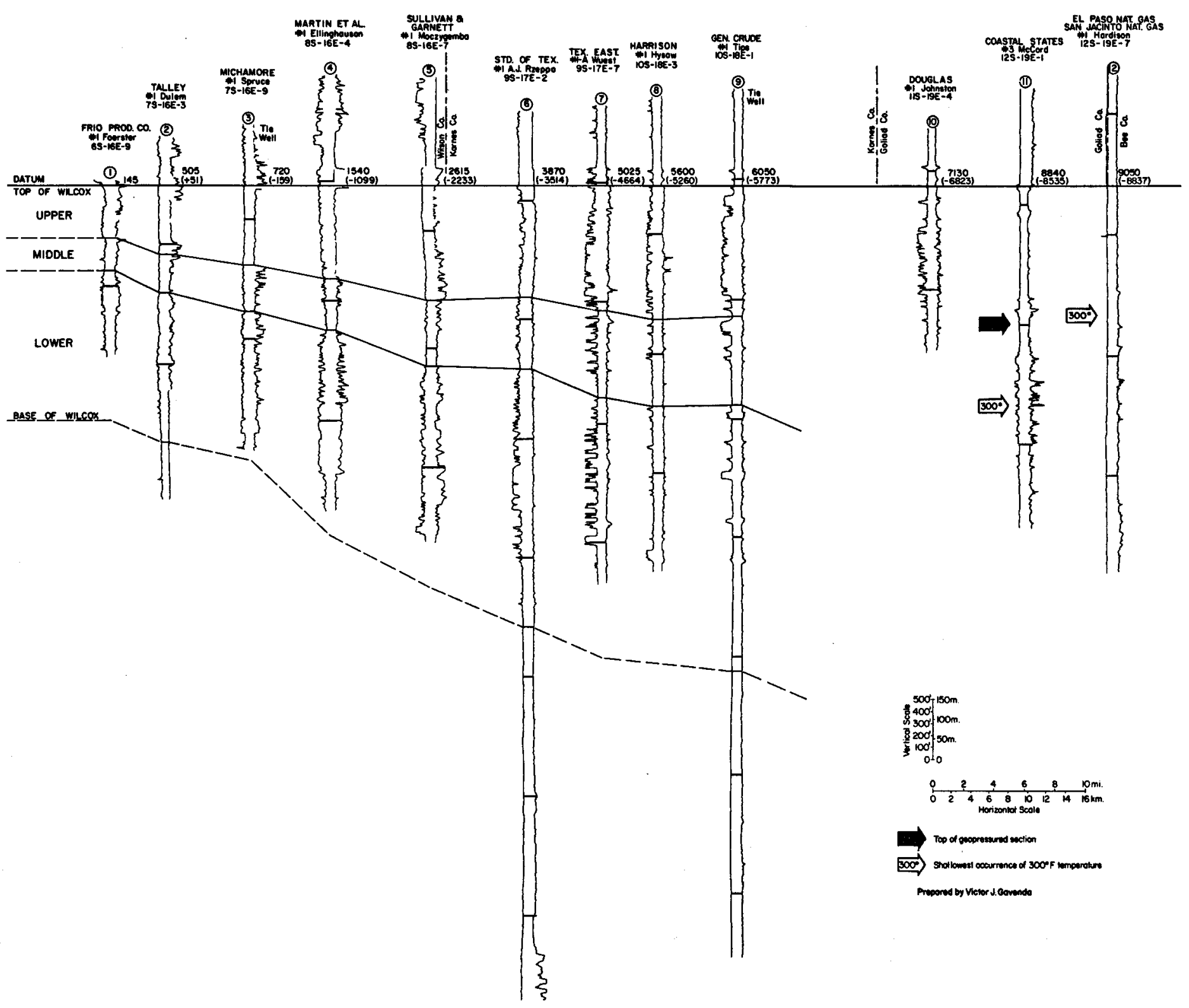

Figure 17. Stratigraphic dip section 8. 


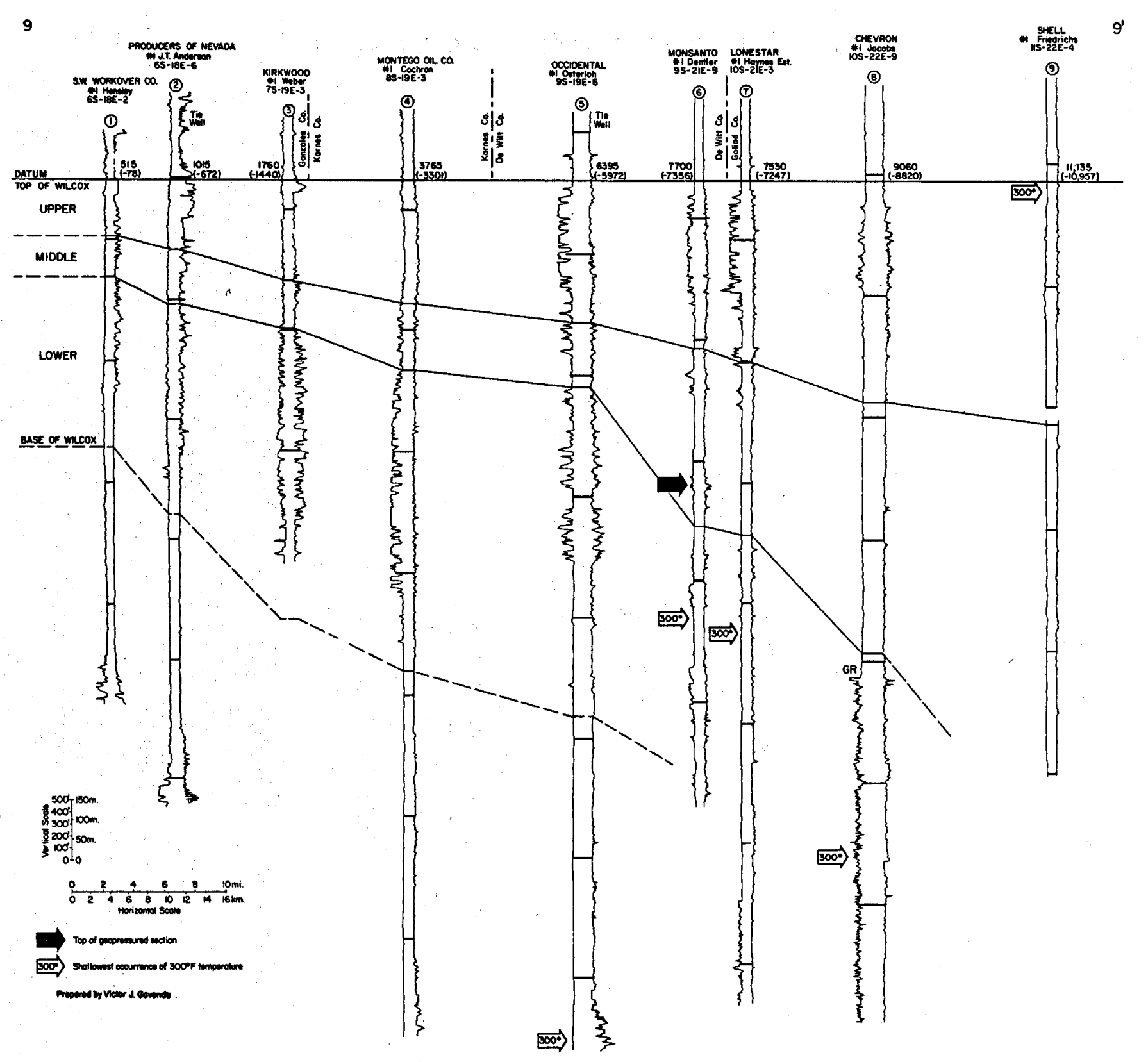

Figure 18. Stratigraphic dip section 9. 


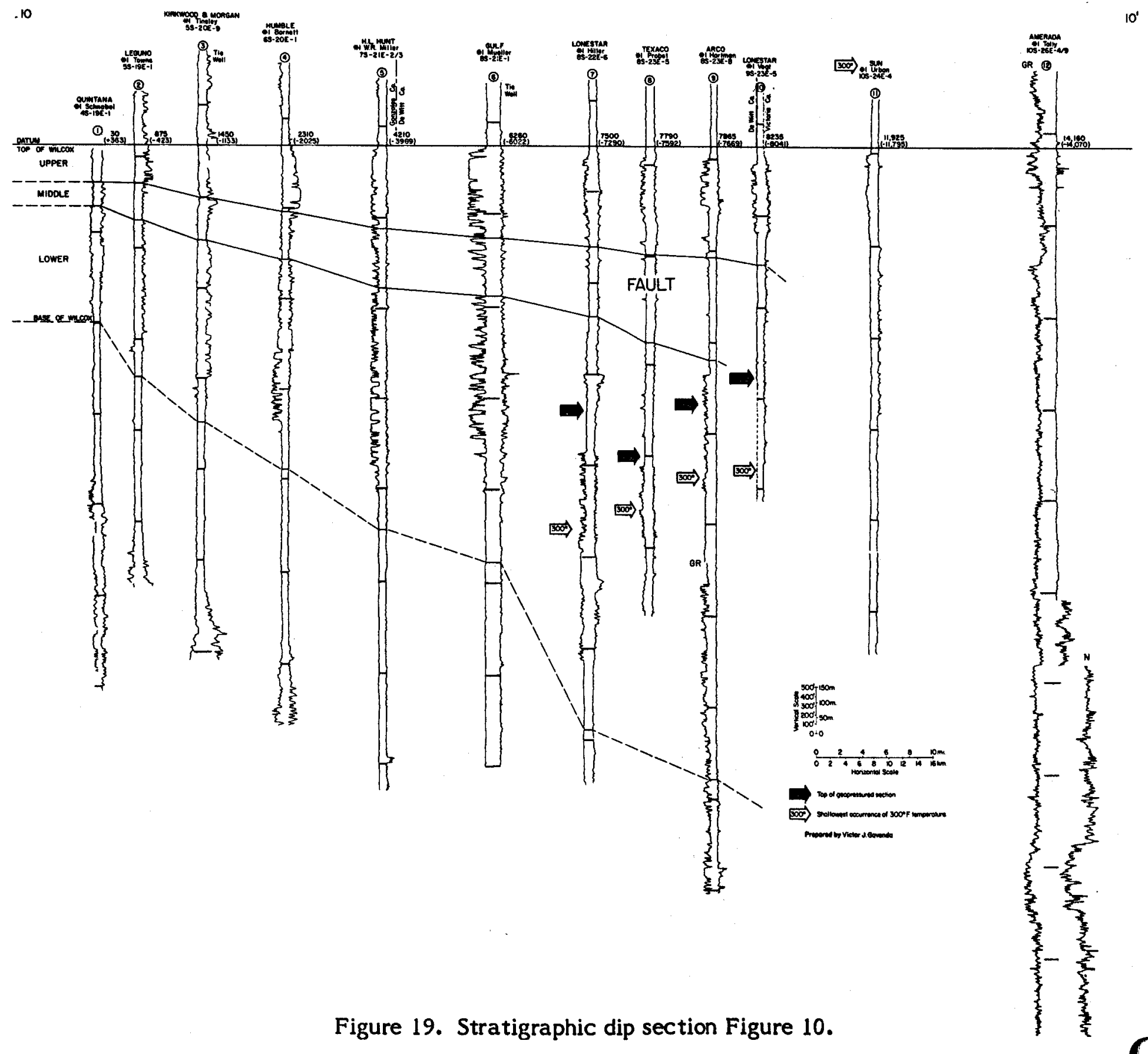


12

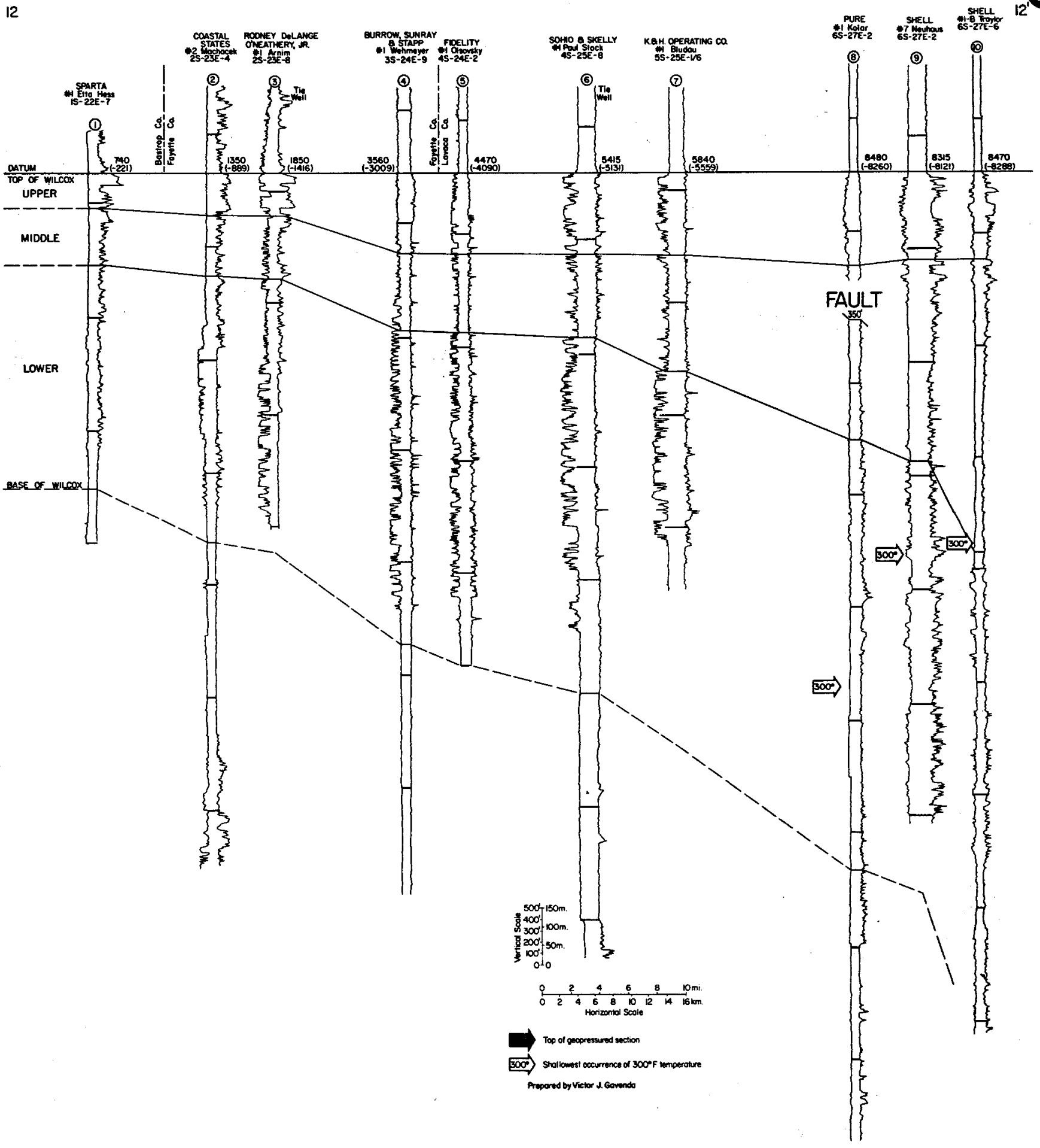

Figure 21. Stratigraphic dip section Figure 12. 
14

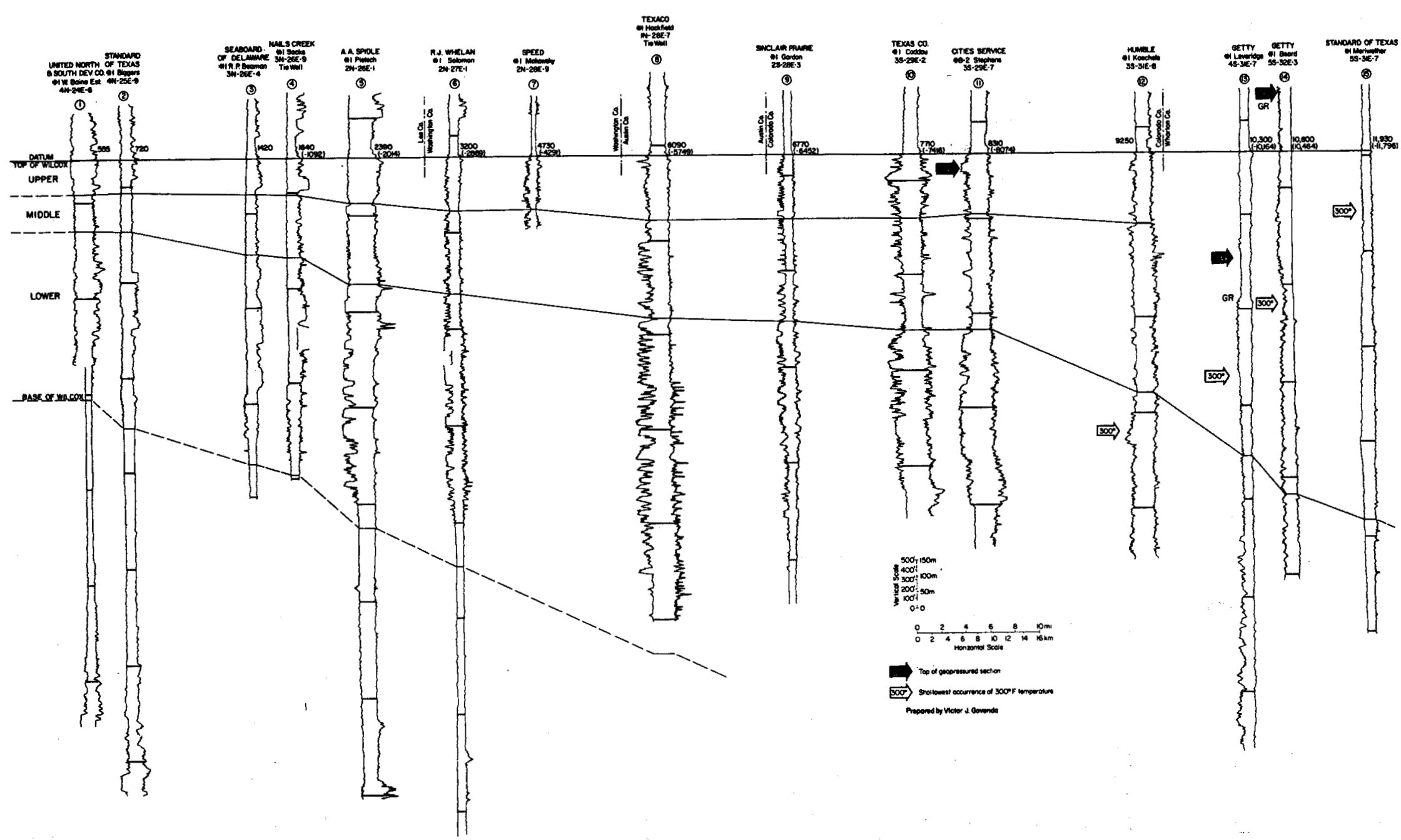

Figure 23. Stratigraphic dip section Figure 14. 


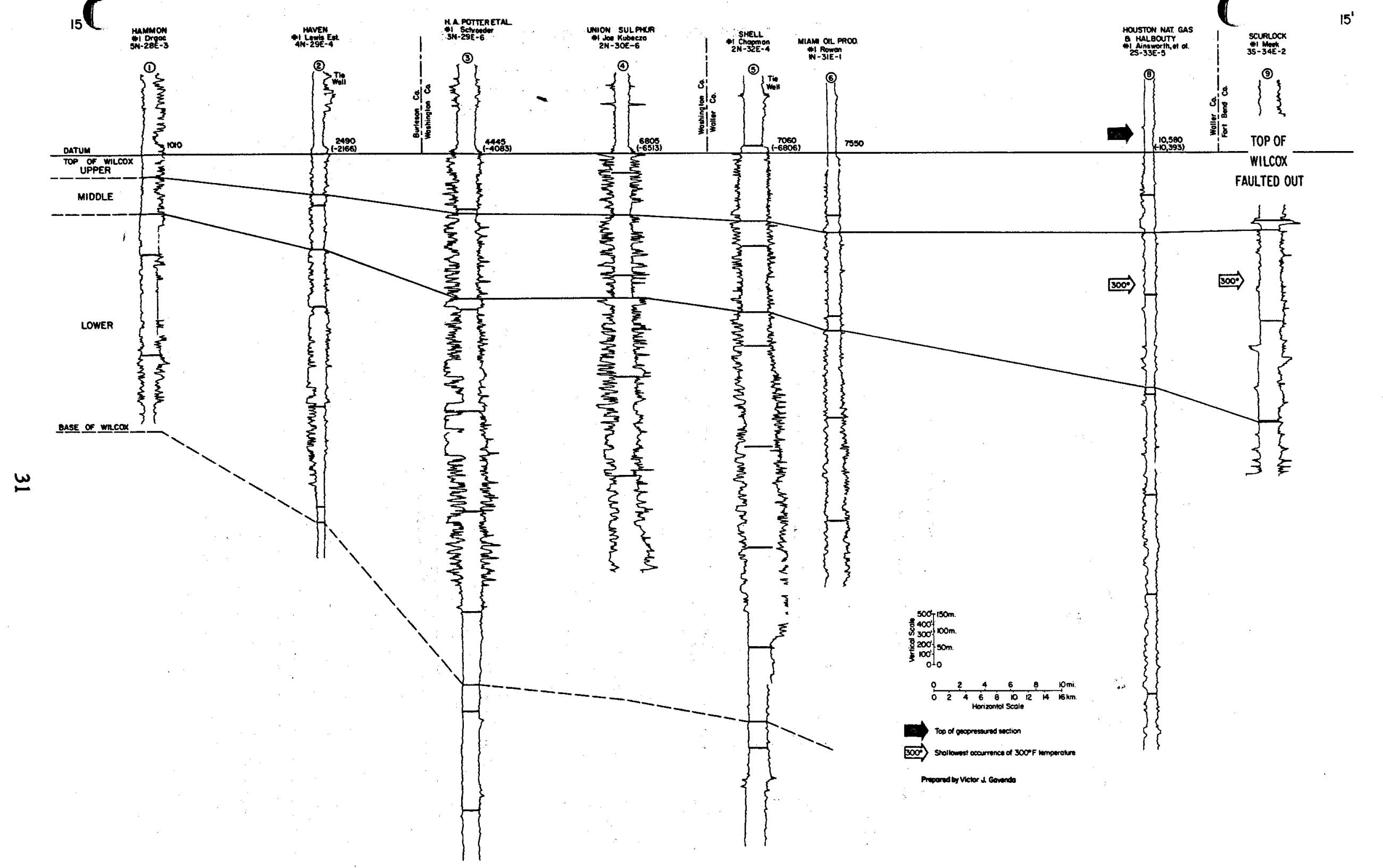

Figure 24. Stratigraphic dip section Figure 15. 


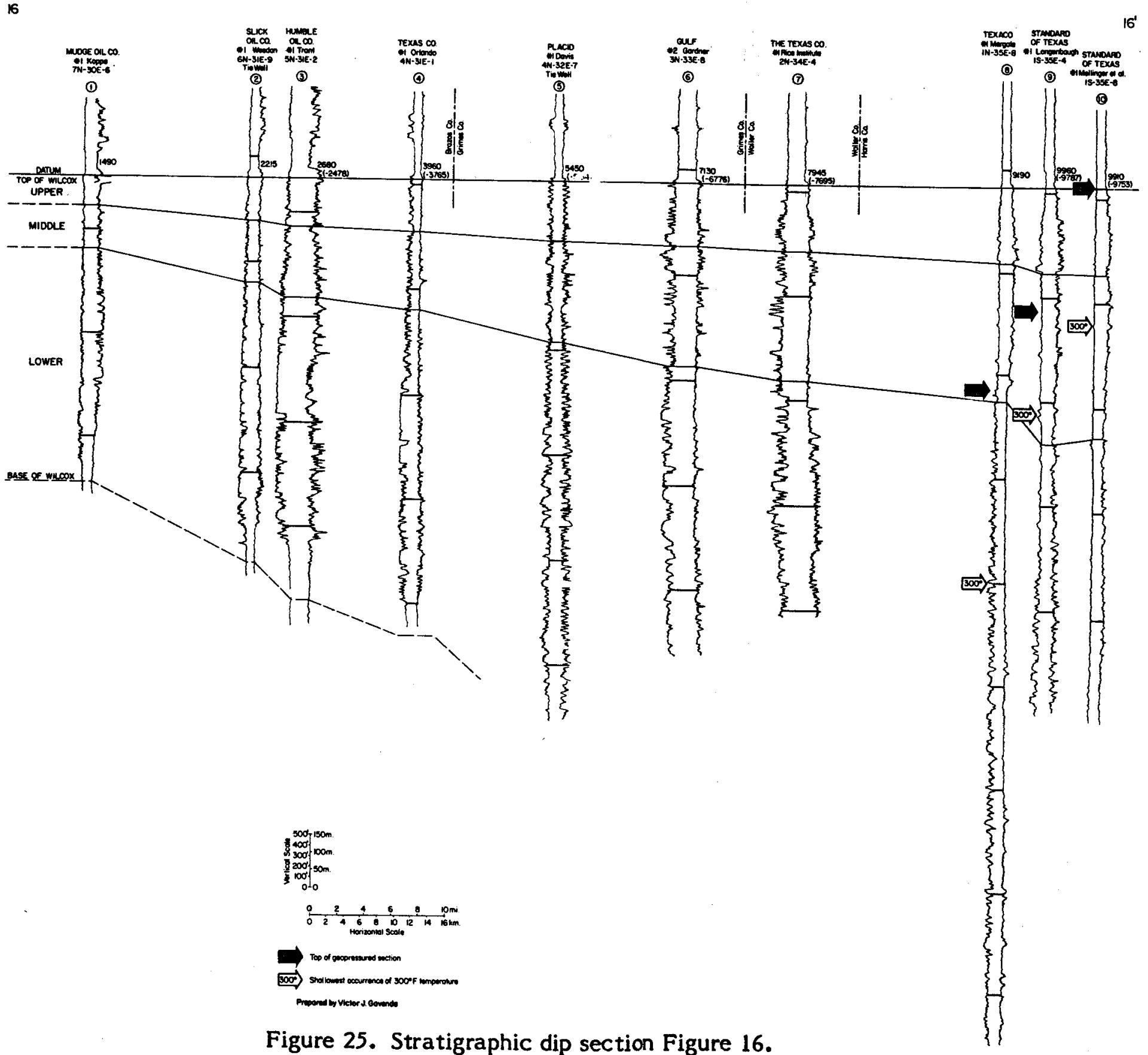




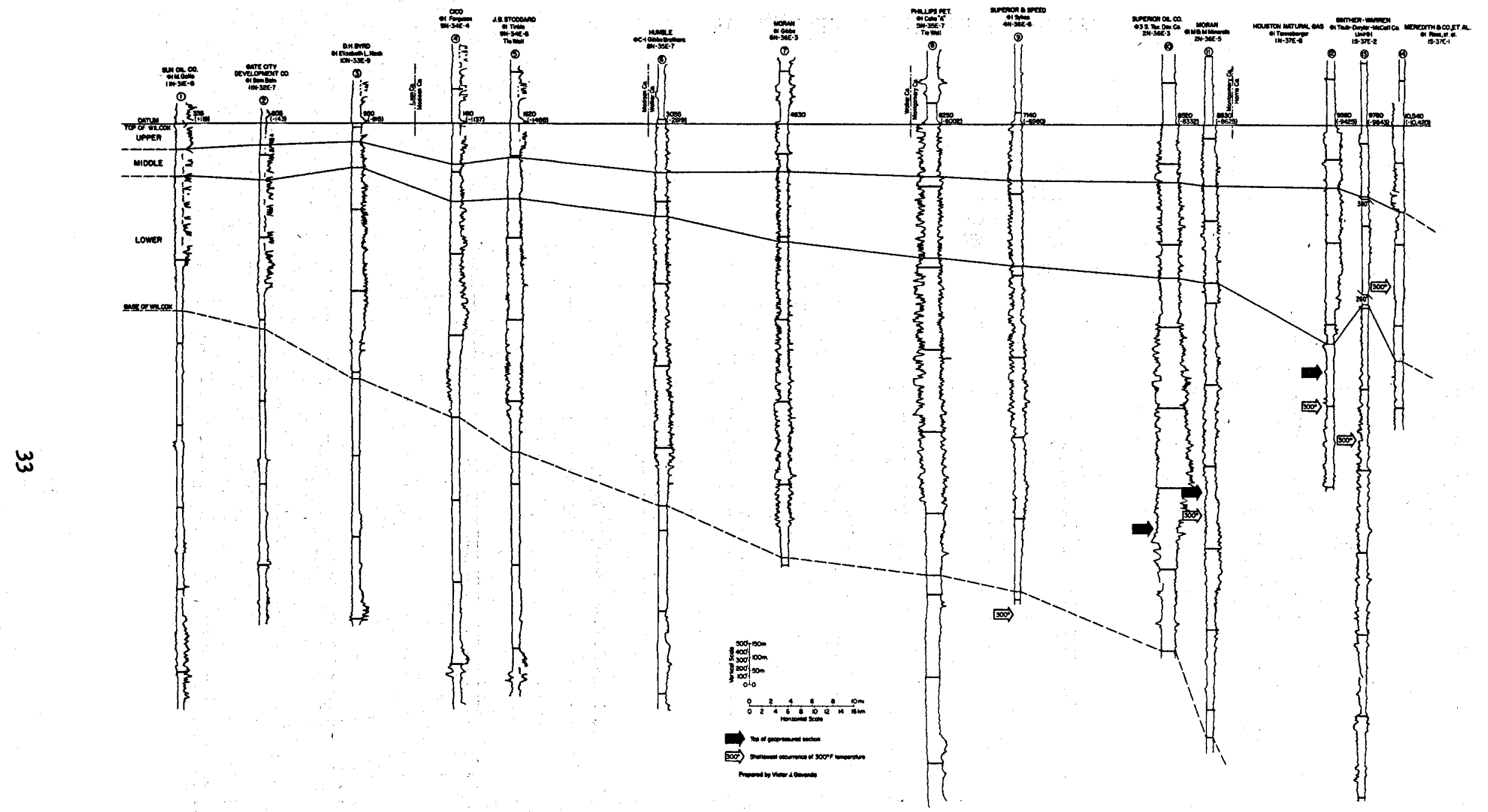

Figure 26. Stratigraphic dip section Figure 17. 


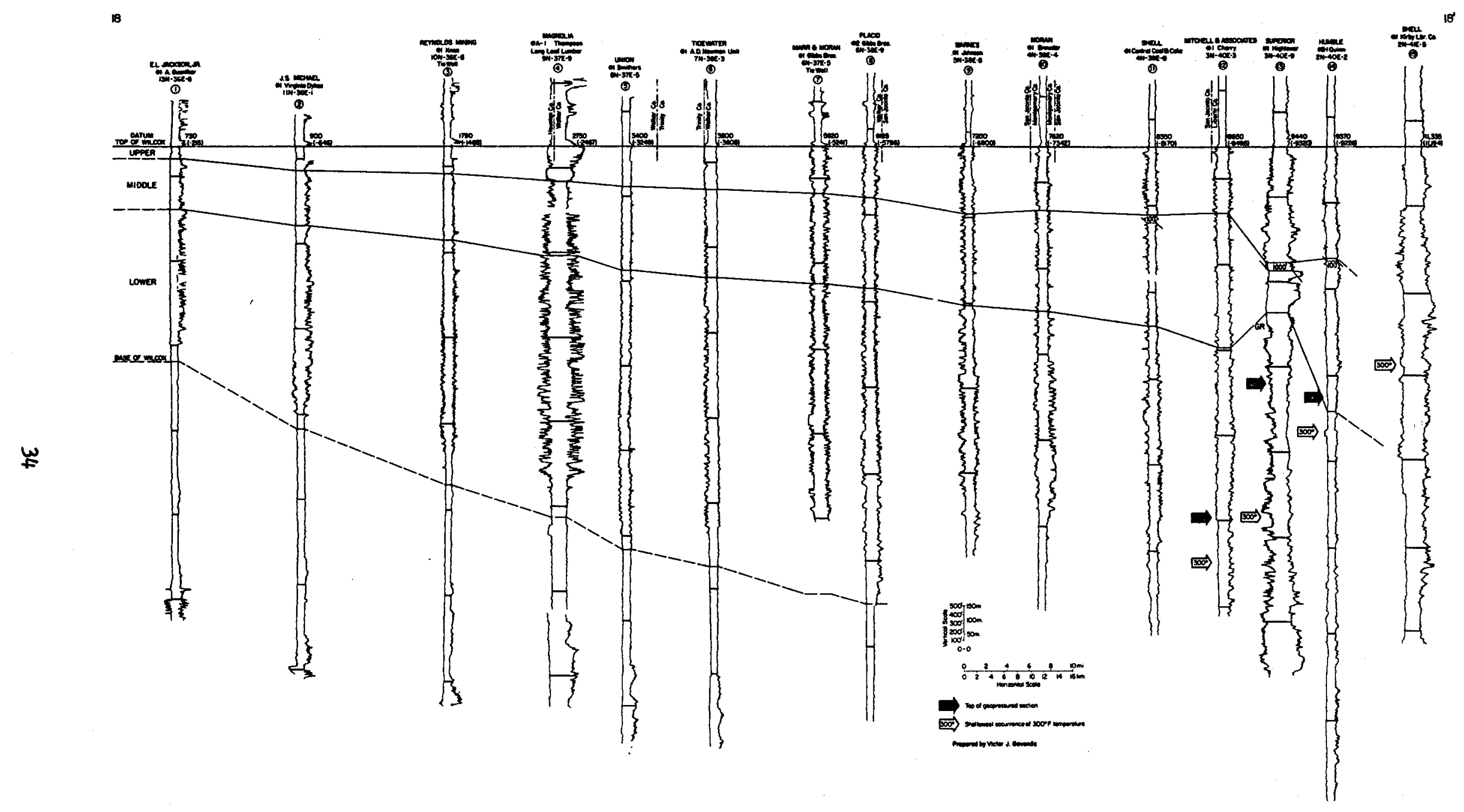

Figure 27. Stratigraphic dip section Figure 18. 


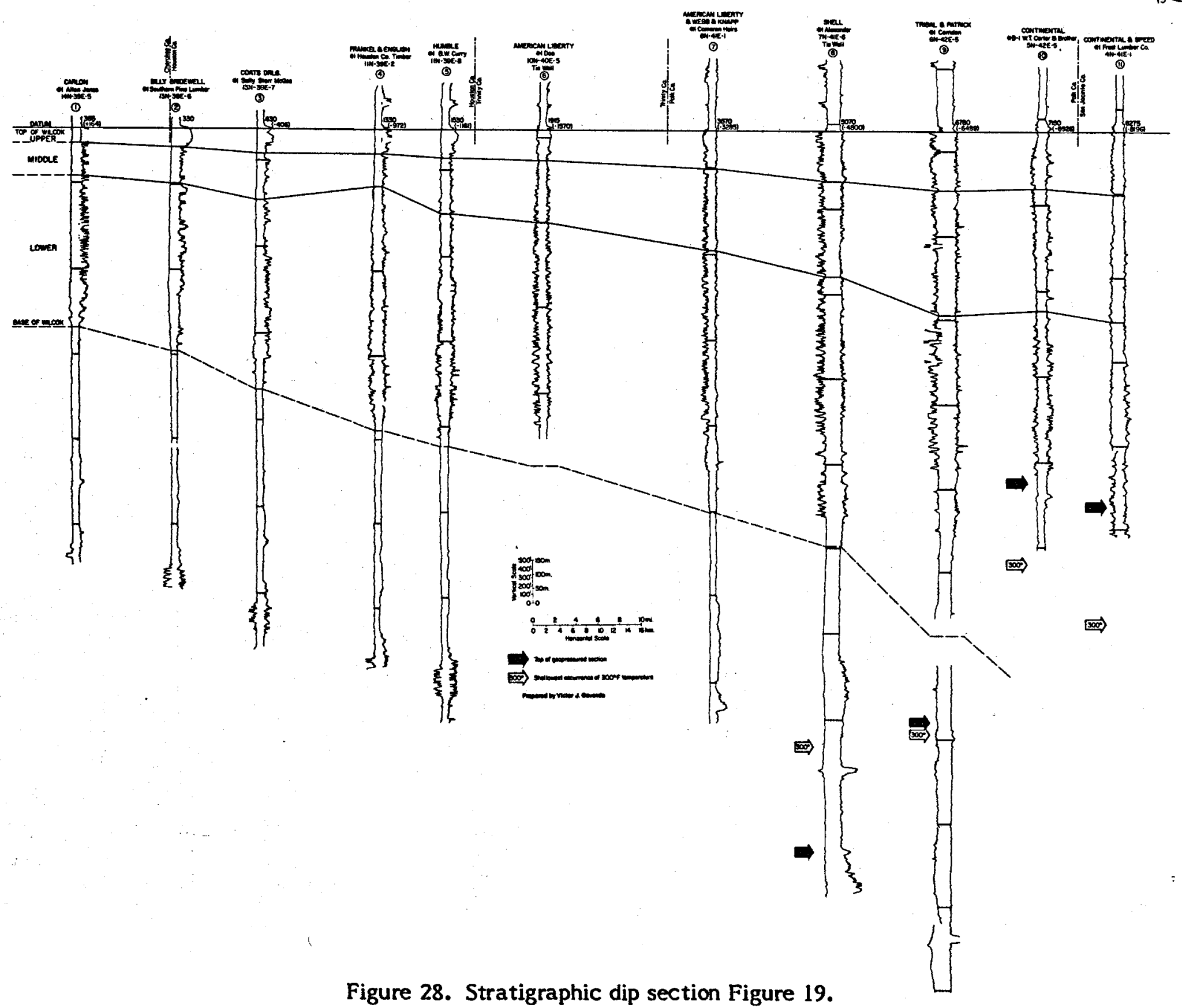




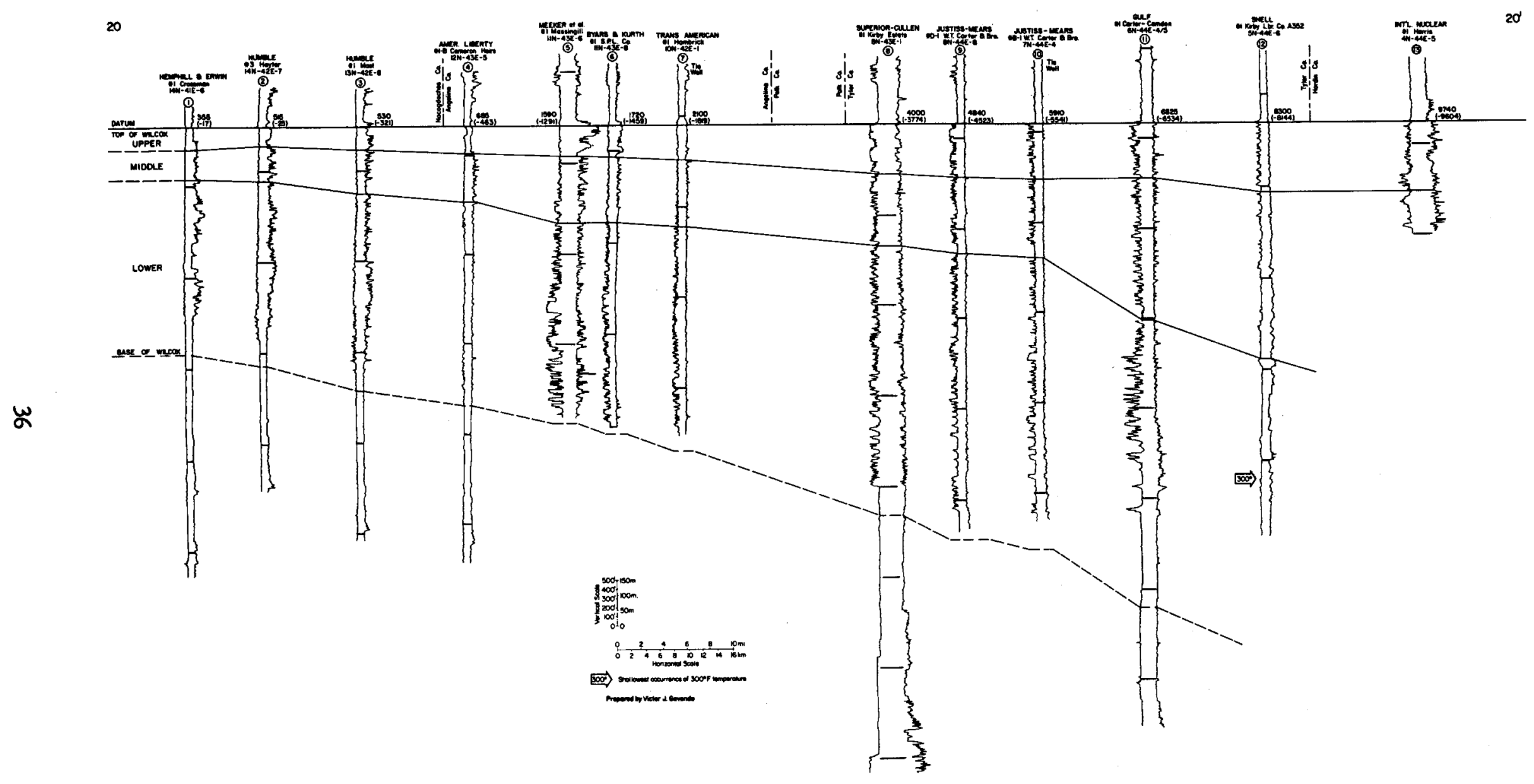

Figure 29. Stratigraphic dip section 20. 


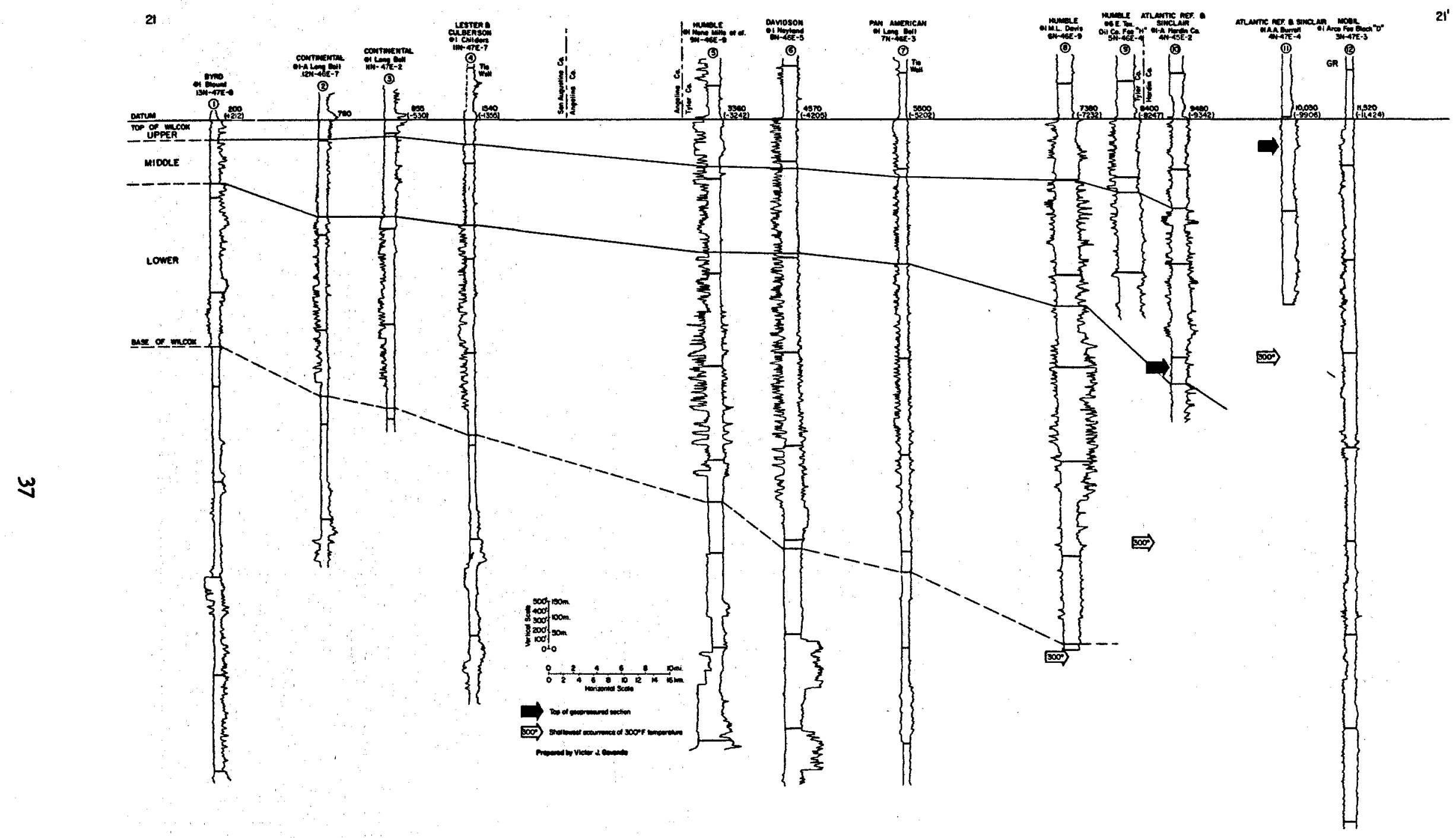

Figure 30. Stratigraphic dip section 21. 


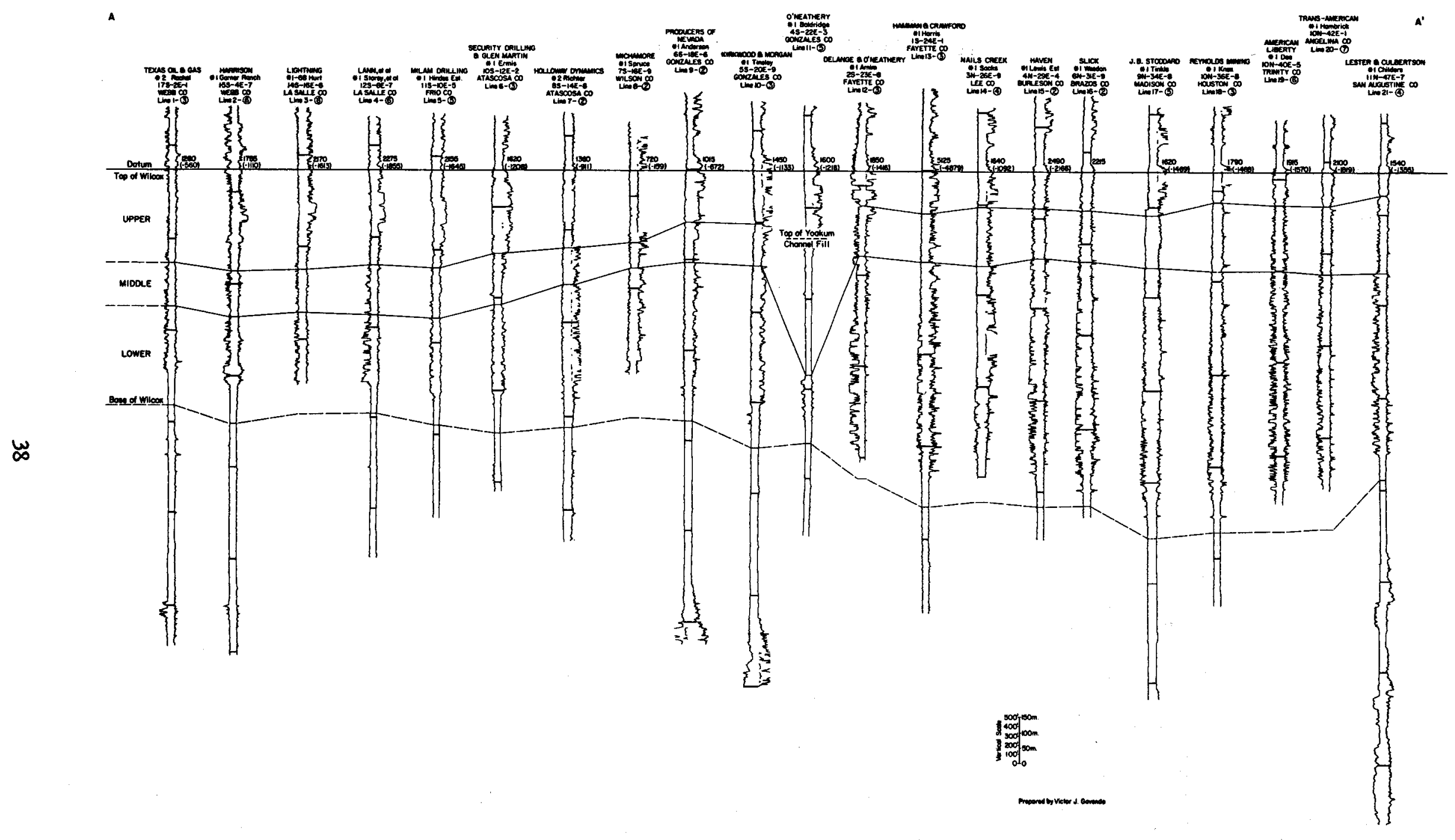

Figure 31. Stratigraphic strike section A. 


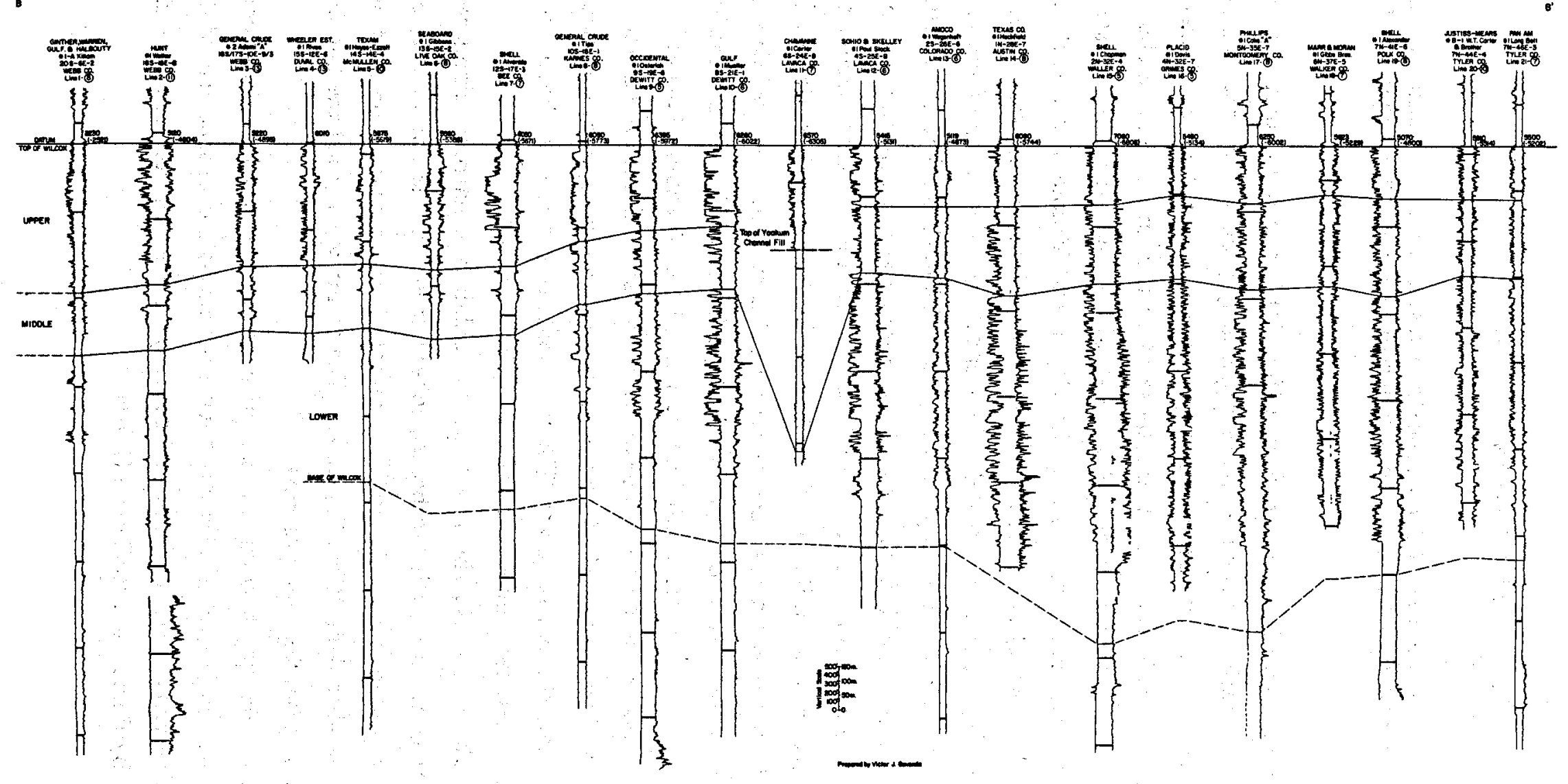

Figure 32. Stratigraphic strike section B. 
LOWER WILCOX SANDSTONE DISTRIBUTION

The regional net-sandstone map outlines a sandstone trend which is broad and lobate along the Upper and Middle Texas Gulf Coast and narrow and elongate along the Lower Texas Gulf Coast.

The net-sandstone map of the lower Wilcox (fig. 33) is based on control provided by wells used in this investigation and by maps previously prepared by the Bureau of Economic Geology as part of an extensive study of the lower Wilcox (Fisher and McGowen, 1967). The maps in this report and those of Fisher and McGowen show that areas of maximum net sandstone trend subparallel to the modern Gulf Coast. The sandstone trends are broad and lobate along the Upper and Middle Texas Gulf Coast (up to $29 \mathrm{~km}$, or $80 \mathrm{mi}$, wide) and narrow and elongate along the Lower Texas Gulf Coast (approximately $32 \mathrm{~km}$, or $20 \mathrm{mi}$, wide). Net-sandstone values range from greater than $610 \mathrm{~m}(2,000 \mathrm{ft})$ to the north to slightly more than $122 \mathrm{~m}(400 \mathrm{ft})$ to the south.

Along the northern two-thirds of the Wilcox trend, the net-sandstone map (fig. 33) exhibits a lobate pattern fom DeWitt County on the south to Sabine County on the north. This lobate pattern is similar to that mapped by Fisher and McGowen (1967) who interpreted it to represent a high-constructive delta system (the Rockdale Delta System). The southernmost delta lobe, the Guadalupe Delta of Fisher and McGowen, was subsequently cut by a large erosional feature named the Yoakum Channel by Hoyt (1959). Fisher and McGowen believe the Yoakum Channel is a submarine canyon which resulted from density flow of reworked deltaic sediments down depositional slope. In the axis of the channel, the entire lower Wilcox sandstone section has been removed and replaced by a dominantly shale section (figs. 31,32 ).

South from DeWitt County, the lower Wilcox exhibits a narrow, elongate netsandstone trend that contrasts with the broad, lobate trend to the north. Fisher and McGowen (1967) suggested that this strike-dominated trend was deposited within strandplain and barrier-bar depositional systems. The trend was named the San Marcos Strandplain and Cotulla Barrier-Bar Systems.

The emphasis of this geothermal assessment is directed toward the most downdip Wilcox sandstone units where reservoirs exist with potential for production of $149^{\circ} \mathrm{C}$ $\left(300^{\circ} \mathrm{F}\right)$ geothermal water. The sandstone lobes of the lower Wilcox coincide closely with interpretation by Fisher and McGowen (1967). 




Figure 33. Net sandstone, lower Wilcox. 
The upper Wilcox is very thick along the Lower Texas Gulf Coast due to extensive growth faulting; in contrast, along the Middle and Upper Texas Gulf Coast, it is relatively thin and unaffected by growth faulting.

The upper Wilcox along the Lower Texas Gulf Coast consists of sandstone and shale and thickens gradually from the outcrop toward the Gulf of Mexico (fig. 34). Downdip, across a distance of about 16 to $24 \mathrm{~km}$ (10 to $15 \mathrm{mi}$ ), the upper Wilcox abruptly thickens as a result of deposition contemporaneous with growth faulting. Along the Middle and Upper Texas Gulf Coast, on the other hand, the upper Wilcox is thinner and not extensively growth faulted (fig. 34). This difference in development of the upper Wilcox is related to the depositional and structural history of the underlying lower Wilcox.

During lower Wilcox deposition, great volumes of sand and mud were transported into the basin in the enormous Rockdale Delta System of the Middle and Upper Texas Gulf Coast (Fisher and McGowen, 1967). However, the Lower Texas Gulf Coast was the site of a large embayment with comparatively modest progradation into the basin. The coastal sediments deposited along this embayment were termed by Fisher and McGowen (1967) as the San Marcos Strandplain Bay System and the Cotulla BarrierBar System; the embayment was bordered toward the Gulf Basin by the South Texas Shelf System, composed predominantly of mud facies. Fisher and McGowen (1967) also identified a shelf-edge sand facies, which was presumed to occur at the seaward margin of the South Texas Shelf System. However, this linear trend, an important gas trend in Lower Texas, is not lower Wilcox; it consists of upper Wilcox deposits which have been growth faulted to great depths.

Consequently, along the Lower Texas Gulf Coast, the upper Wilcox deltas prograded over muddy, unstable sediments of the lower Wilcox shelf margin and were extensively affected by growth faulting. Along the Middle and Upper Texas Gulf Coast, in contrast, upper Wilcox deltas prograded over relatively sandy lower Wilcox deposits which, although themselves extensively growth faulted, provided a stable platform; thus, in these areas, upper Wilcox strata are not extensively growth faulted in the area of well control and the deltas do not appear to have transported appreciable quantities of sand to the lower Wilcox shelf margin.

The upper Wilcox growth fault zone is about 16 to $24 \mathrm{~km}$ (10 to $15 \mathrm{mi}$ ) wide, and dip sections transect many faults. Just updip of the fault zone, the top of the Wilcox is generally at a depth of about $1,800 \mathrm{~m}(6,000 \mathrm{ft})$. In this zone, the upper Wilcox 
ranges in thickness from $430 \mathrm{~m}(1,400 \mathrm{ft})$ in the north to $580 \mathrm{~m}(1,900 \mathrm{ft})$ in the south. Across the fault zone, the top of the Wilcox occurs at depths as great as 2,750 to $3,660 \mathrm{~m}$ $(9,000$ to $12,000 \mathrm{ft})$. Downdip, total thickness for the upper Wilcox cannot be determined because of the lack of sufficiently deep wells, but correlation of selected intervals of the upper part of the Wilcox indicates growth ratios ranging from about 6 to 10 and the deepest downdip wells penetrate $1,800 \mathrm{~m}(6,000 \mathrm{ft})$ of upper Wilcox.

A strike stratigraphic section from Zapata to Karnes Counties relates the sandstone-bearing intervals of the three fairways in South Texas (fig. 35). The section shows that the high-sandstone areas of the fairways extend 21 to $100 \mathrm{~km}$ (13 to $60 \mathrm{mi}$ ) along strike, and that the prospective sandstones present in the fairways developed at different times and do not correlate. Thus, the oldest sandstone unit, situated in the lower part of the upper Wilcox, occurs in the Duval Fairway, below marker Du3. The intermediate sandstone, situated in the middle part of the upper Wilcox, occurs in the Zapata Fairway, between markers $Z 2$ and $Z 3$. The youngest sandstone, at the top of the upper Wilcox, occurs in the Live Oak Fairway, above marker L2.

Along strike to the northeast in Karnes County, the upper Wilcox is commonly developed as a massive sandstone, with only minor, thin shale intervals. The homogeneous development renders long-distance correlation impossible. As mentioned earlier, these sandstone-rich sequences in the upper Wilcox of central and eastern areas rapidly shale out downdip across the growth-faulted zone. In contrast to this, sandstone and shale intervals in the upper Wilcox of South Texas are comparatively easy to correlate. Downdip, across the growth-fault zone, shales become more dominant, but this generally occurs at great depth. Detailed examination of logs from both sides of major growth faults shows that the sandstone/shale ratio is not appreciably altered by the growth faults, even where the thickness is increased by a factor of two or more.

The geographic restriction of sandstone depocenters along strike indicates that the dispersal system was not strike oriented on a regional scale. Furthermore, evidence against strike-transport of sediment from a Middle to Upper Texas Gulf Coast source is provided by the dominance of volcanic over metamorphic rock fragments in Lower Texas Wilcox sandstones, the reverse of which is observed in Middle and Upper Texas Gulf Coast. These volcanic rock fragments were probably derived from volcanic centers in Northern Mexico and West Texas (Loucks, Bebout, and Galloway, 1977). In updip areas, log patterns generally show a blocky pattern with sudden changes laterally, and the sediments are interpreted as having been deposited in distributary channels. In contrast, sediments in downdip areas which show coarsening-upward trends are interpreted as having been deposited as delta-front and distributary-mouth bar facies. 


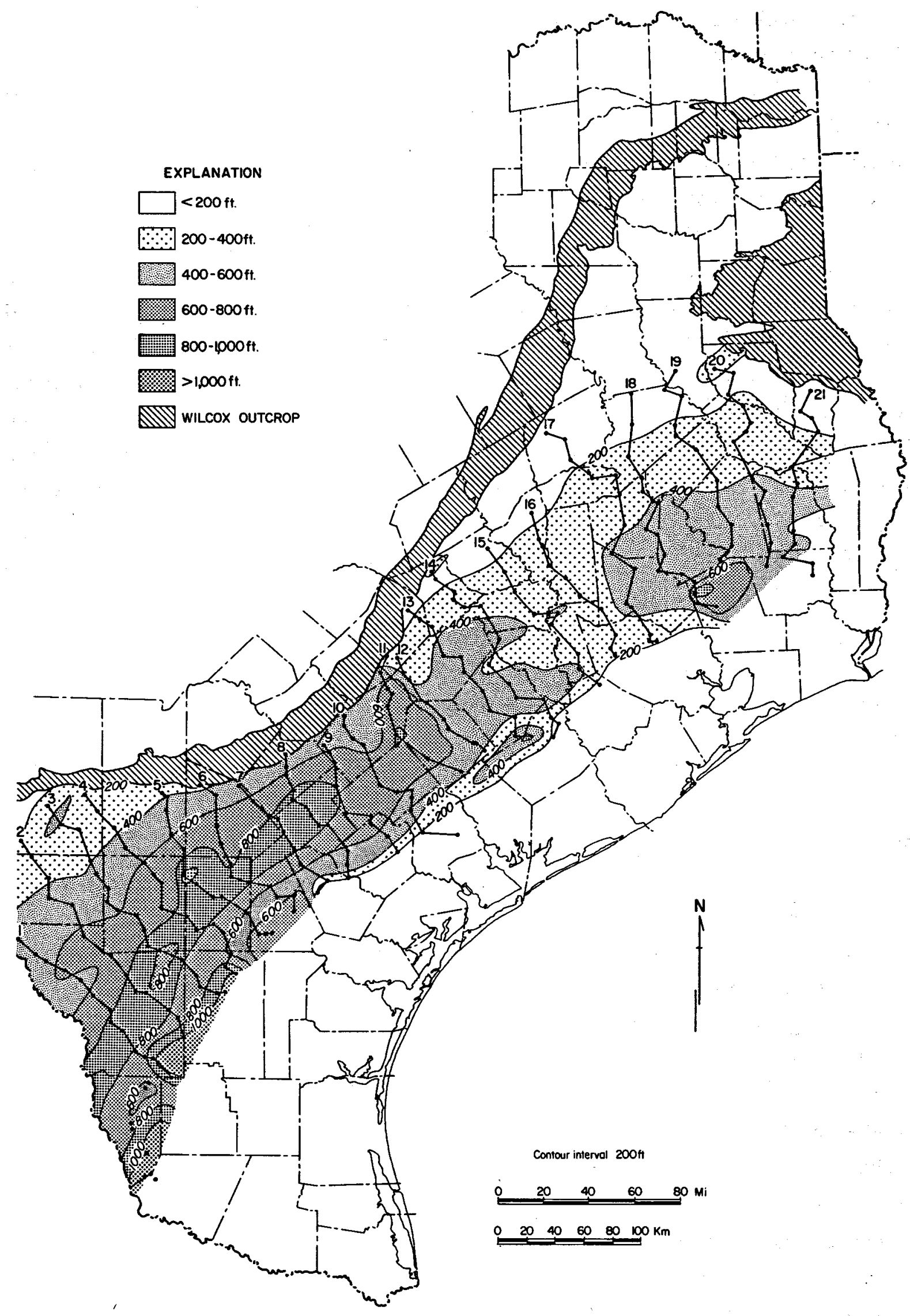

Figure 34. Net sandstone, upper Wilcox. 


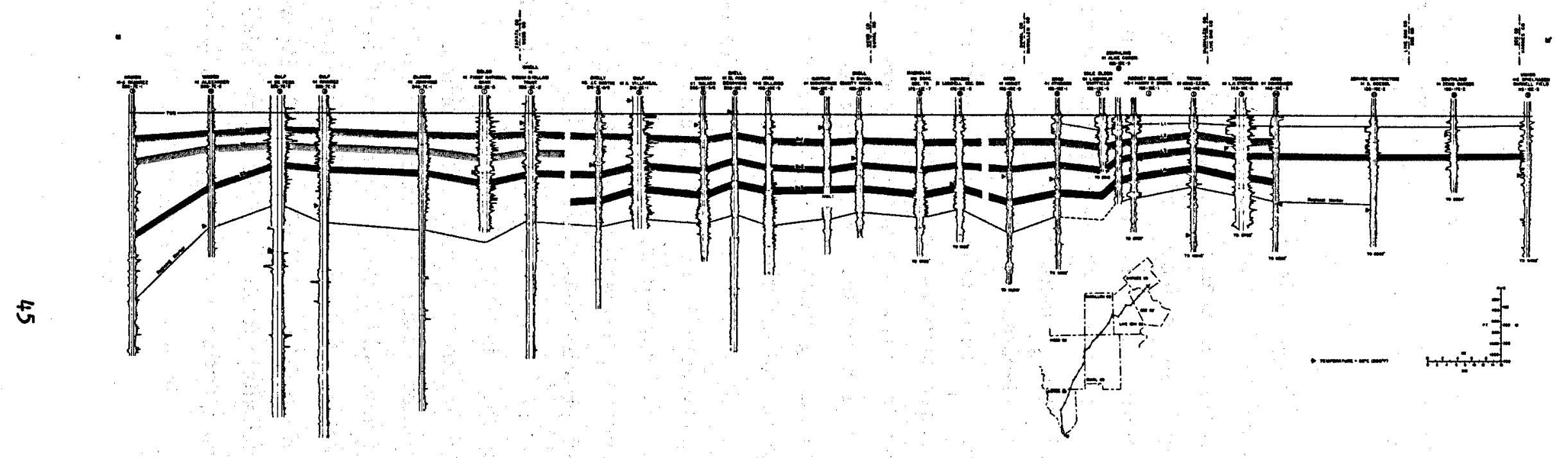

Figure 35. Stratigraphic strike section of the upper Wilcox, Lower Texas Gulf Coast. 
The top of geopressure, determined from resistivity logs and drilling-mud weights, occurs at depths of 2,400 to 3,000 $\mathrm{m}(8,000$ to $10,000 \mathrm{ft})$ in areas where the Wilcox is dominantly shale and at depths of 3,400 to $4,000 \mathrm{~m}(11,000$ to $13,000 \mathrm{ft})$ where the Wilcox is dominantly sandstone.

Bottom-hole shut-in pressure (BHSIP) data from drill-stem tests (DST) obtained from completion cards are available only from producing wells. To supplement these measured pressure data, fluid pressure in shales was determined primarily by using data from resistivity logs. Detection and evaluation of geopressured formations using the short-normal curve or amplified short-normal curve of the electrical log (Hottmann and Johnson, 1965) relies on the observation that, under conditions of normal compaction, shale resistivity $\mathrm{R}_{\text {sh }}$ increases with depth as the porosity and water content of shales decrease. Geopressured shale resistivities depart from the normal trend and lower values of $\mathbf{R}_{\text {sh }}$ are recorded because of the increased porosity and water content of the geopressured shales. The amount of divergence of $R_{\text {sh }}$ from the established normal compaction trend is a measure of the pore-fluid pressure in the shale and adjacent sandstone. Normal procedure for detecting geopressures involves a semilog plot with $\mathbf{R}_{\text {sh }}$ plotted on the logarithmic scale and depth on the linear scale (fig. 36). Shale with higher than normal resistivity (cap rock) is frequently observed above the top of geopressure. This transition zone from hydropressured to geopressured conditions may be sharp and definitive or gradual and equivocal.

Divergence of $\mathbf{R}_{\text {sh }}$ from the normal compaction trend is related to the observed pressure gradient in adjacent sandstone formations. A plot of the gradient for ratio $R_{\text {sh }}$ (normal)/ $R_{\text {sh }}$ (observed) versus pressure (observed) for Eocene formations (fig. 37) was developed for DeWitt County. Using this curve, geopressure profiles can be constructed for individual wells in the area.

Top of geopressure in the Wilcox was interpreted primarily by analysis of resistivity logs (fig. 38). Supplementary data from sonic logs and drill-stem tests were also used. To establish the trend line, only shales greater than $10 \mathrm{~m}(30 \mathrm{ft})$ thick were picked; silty, calcareous, and washed-out shales were avoided. Resistivity data for shales at depths less than 1,200 to $1,500 \mathrm{~m}(4,000$ to $5,000 \mathrm{ft})$ were disregarded because these shallow formations contain fresh water with high resistivity values that cannot be used to establish the compaction trend; the presence of gas-cut mud or mud containing additives to combat lost circulation also contributes to spurious resistivity 
data. Other discontinuities observed in the trend line may be caused by an abrupt change in lithology (such as bentonitic shales), difference in the geologic age with consequent drastic changes in shale properties, or major changes in bit size. Shales located near salt masses were avoided because their low resistivity (high salinity) may falsely indicate higher than normal pressure.

Mud weight versus depth recorded on resistivity plots (fig. 36) provides a first approximation of the location of the transition zone. Although mud weights alone are inaccurate and can be misleading for picking geopressure tops, a mud weight of 14.8 to $16.0 \mathrm{kPa} / \mathrm{m}$ (12.6 to $13.6 \mathrm{lbs} / \mathrm{gal})$ is used to first approximate the depth of the transition zone when the quality of well log data is questionable. Depth to geopressure top can then be adjusted after correlations with suitable logs and pressure data from nearby wells. Mud weights from well logs are not recommended for quantitative evaluation of geopressure.

In fresh-water zones, sonic logs are considered more reliable than electrical logs for locating and evaluating geopressures. By plotting on semilog paper shale transit time-versus-depth (fig. 36), the normal compaction curve (NNC) is established and the geopressure top is located at the depth where shale transit time departs from the normal trend. Usually there is good correlation between top of geopressure picked from shale resistivity and from shale interval-transit times. In the example from the Atlantic No. 1 Kerlick, however, the pick from the transit time plot is about $183 \mathrm{~m}$ $(600 \mathrm{ft})$ above the pick from shale resistivity.

In this report, top of geopressure was picked from bottom-hole pressure data for county areas and from shale-resistivity data for individual wells. The possibility of ambiguity exists because definitions of top of geopressure differ for the two cases depending on the intended application. Top of geopressure from bottom-hole shut-in pressures refers to an average pressure gradient of $10.5 \mathrm{kPa} / \mathrm{m}(0.465 \mathrm{psi} / \mathrm{ft})$ determined by least squares fit to data for wells located in a given area. Other average pressure gradients can also be determined from the curve (fig. 140). Top of geopressure from shale-resistivity data (fig. 36a) refers to the depths at which $R_{\text {sh }}$ is reduced to values which fall to the left of the normal compaction curve. If a cap rock is present, top of geopressure is picked at its base. At this point pressure gradients average $15.8 \mathrm{kPa} / \mathrm{m}(0.7 \mathrm{psi} / \mathrm{ft})$ and are large enough to provide driving forces that will produce geothermal waters. A pressure gradient of $10.5 \mathrm{kPa} / \mathrm{m}(0.465 \mathrm{psi} / \mathrm{ft})$ occurs at the top of the cap rock. 


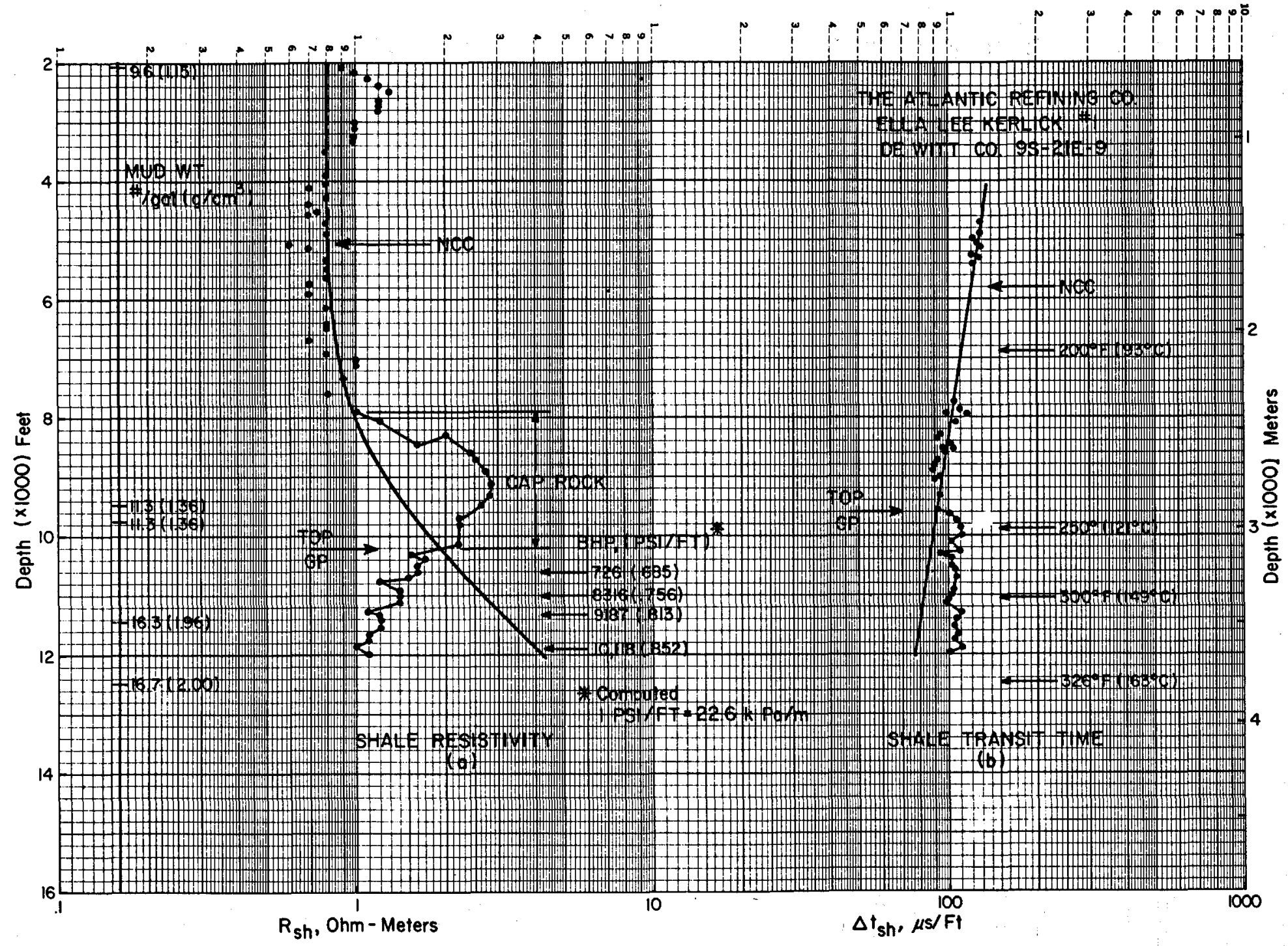

Figure 36. Top of geopressure picked from shale resistivity and transit times for a well in De Witt County. 


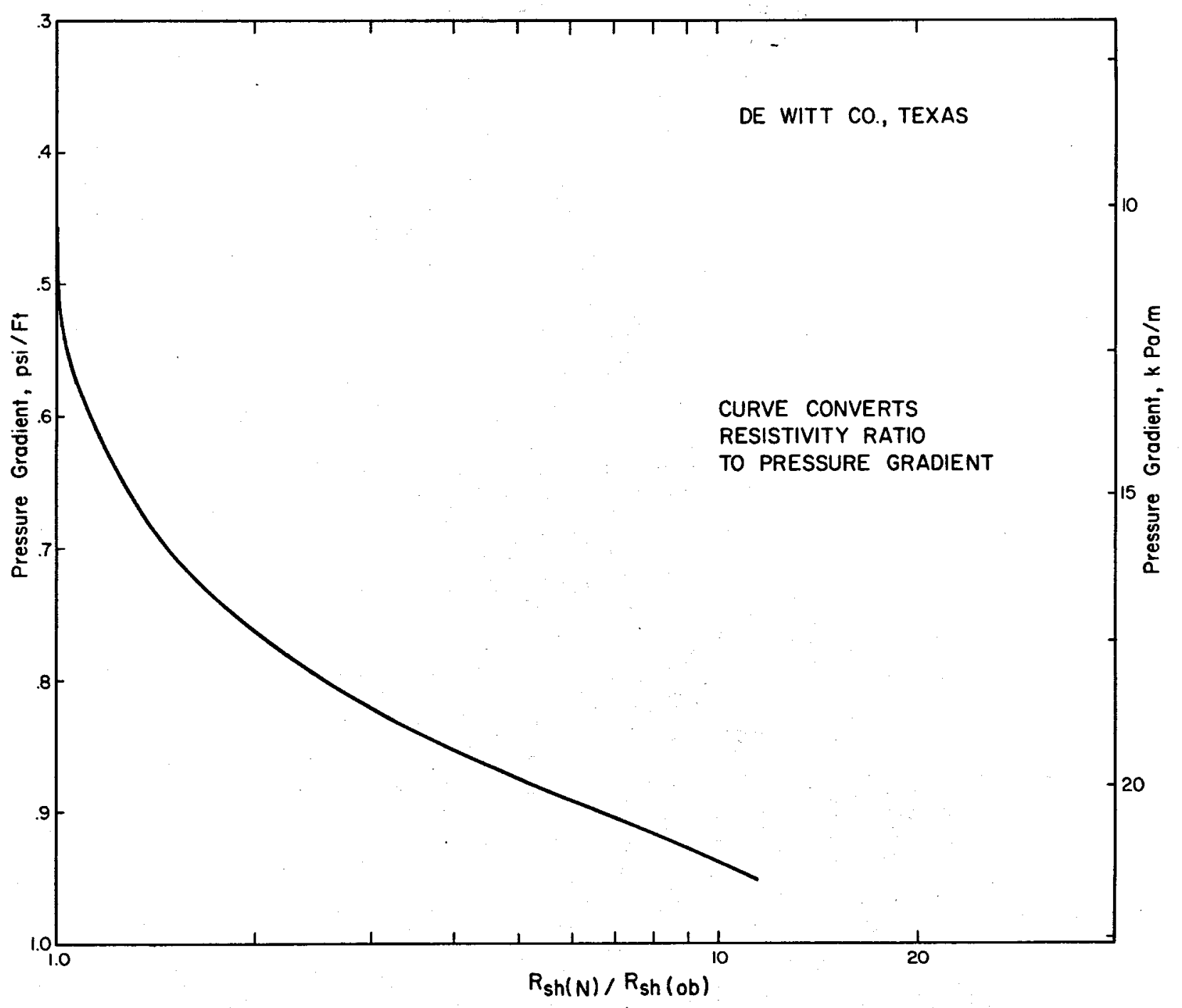

Figure 37. Shale resistivity ratio curve obtained for De Witt County. 


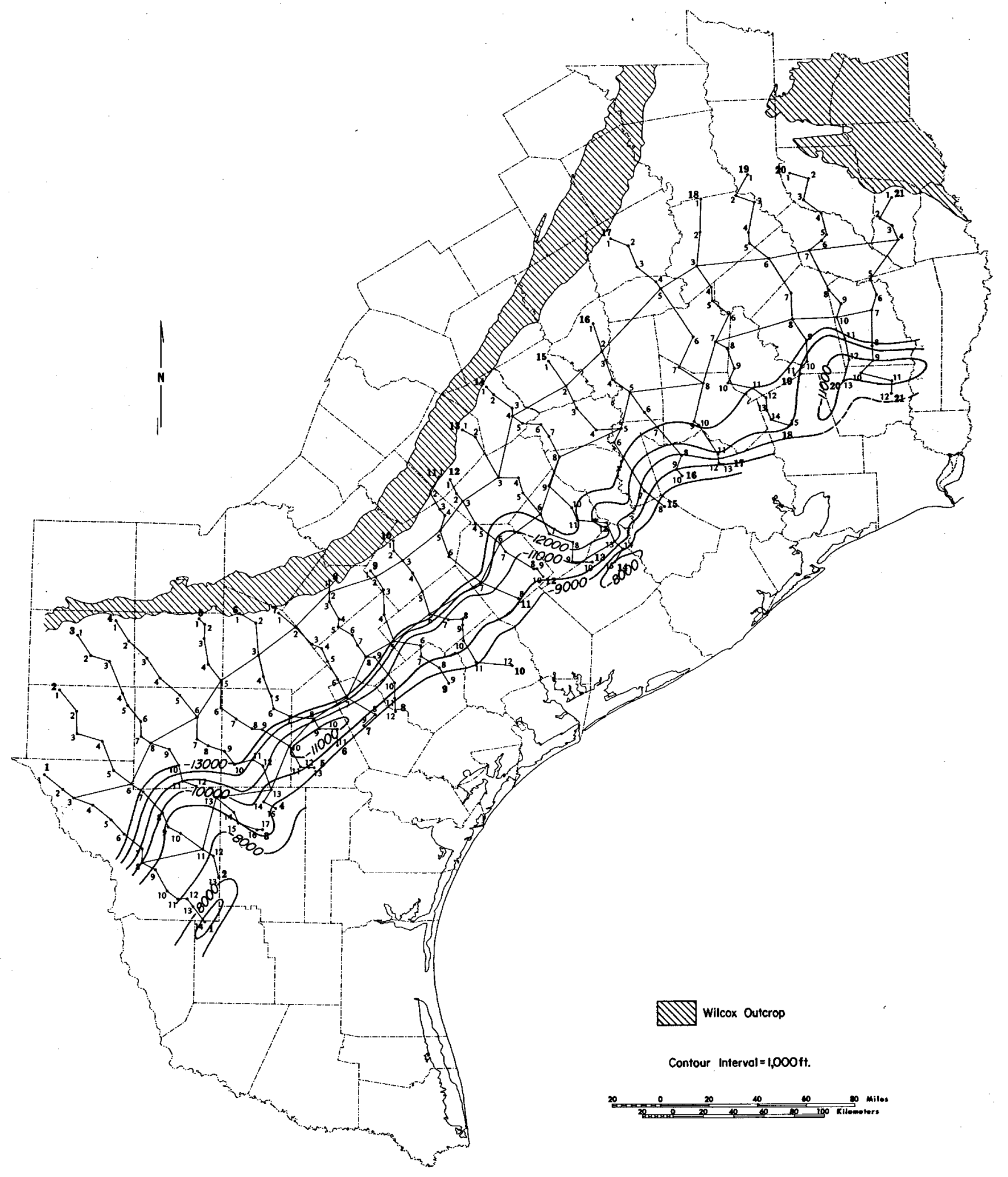

Figure 38. Top of geopressure within the Wilcox Group, Texas Gulf Coast. 
Geothermal fairways are areas in which thick sandstones occur deeper than the depth at which formation temperatures are $149^{\circ} \mathrm{C}\left(300^{\circ} \mathrm{F}\right)$.

Formation temperatures have been recorded in this study primarily as a tool to delineate areas where thick sandstone reservoirs have temperatures greater than $149^{\circ} \mathrm{C}\left(300^{\circ} \mathrm{F}\right)$. However, knowledge of the formation temperatures is also essential in calculating the amount of methane in solution in the water and in studying the changes in diagenesis of the sandstone, shale, and organic material with depth (Burst, 1959, 1969; Dow, 1978). Thus, temperature has a profound effect on controls of porosity, permeability, and elastic properties of prospective reservoir rocks.

The depth below which subsurface temperatures exceed $149^{\circ} \mathrm{C}\left(300^{\circ} \mathrm{F}\right)$ is indicated on all wells on the stratigraphic sections (figs. 10 to 32). Geothermal fairways were identified by plotting the $149^{\circ} \mathrm{C}\left(300^{\circ} \mathrm{F}\right)$ isotherm on the net-sandstone maps of lower and upper Wilcox (figs. 39 and 40). Minimum thickness of sandstone penetrated by deep wells with temperatures higher than $149^{\circ} \mathrm{C}\left(300^{\circ} \mathrm{F}\right)$ are shown gulfward of this isotherm. Six fairways have been outlined in this manner (fig. 41)Harris, Colorado, DeWitt, Live Oak, Duval, and Zapata.

Plots showing the geothermal gradient of wells in these fairways along the Wilcox trend illustrate three changes of slope with depth, referred to here as shallow, medium, and deep (figs. 42 to 44). In addition, gradients increase and higher temperatures occur shallower toward the southwest along the Wilcox trend.

Temperature data used to obtain gradients for this report were taken from well logs and corrected to approximate thermal equilibrium by the empirical relation developed by Kehle (1971).

$T_{E}=T_{L}-8.819 \times 10^{-12} D^{3}-2.143 \times 10^{-8} D^{2}+4.375 \times 10^{-3} D-1.018$ where

$T_{E}=$ equilibrium temperature, ${ }^{\circ} \mathrm{F}$

$T_{L}=$ bottom-hole temperature from well logs, ${ }^{\circ} \mathrm{F}$ and

$\mathrm{D}=$ depth, feet 


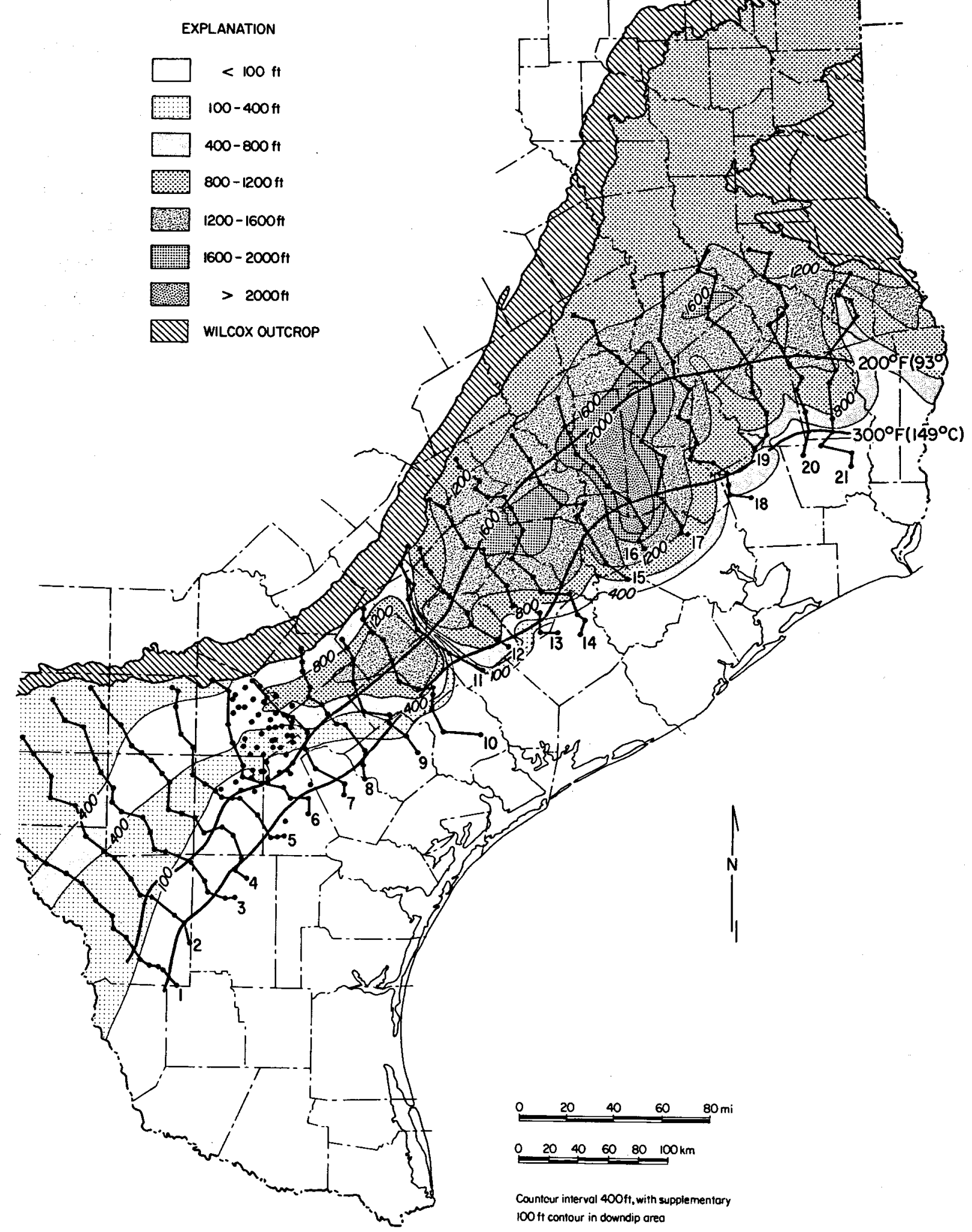

Figure 39. Net sandstone of the lower Wilcox with the 93 and $149^{\circ} \mathrm{C}\left(200\right.$ and $\left.300^{\circ} \mathrm{F}\right)$ isotherms. 
EXPLANATION

] $<200 \mathrm{ft}$.

$\because \because 200-400 \mathrm{ft}$

400-600 ft.

600-800ft.

800-1000ft.

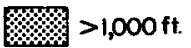

WILCOX OUTCROP

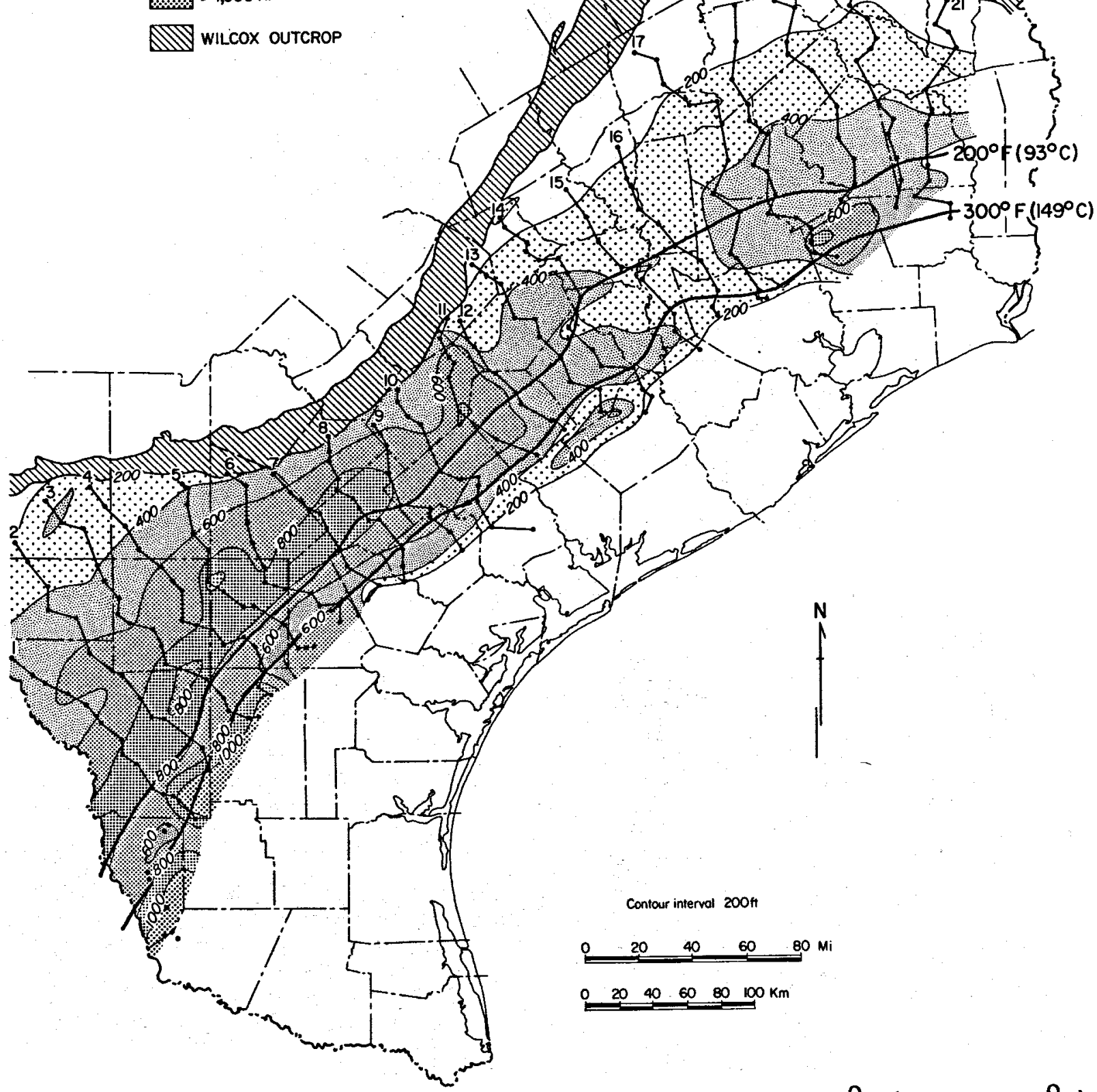

Figure 40. Net sandstone of the upper Wilcox with the 93 and $149^{\circ} \mathrm{C}\left(200\right.$ and $\left.300^{\circ} \mathrm{F}\right)$ isotherms. 


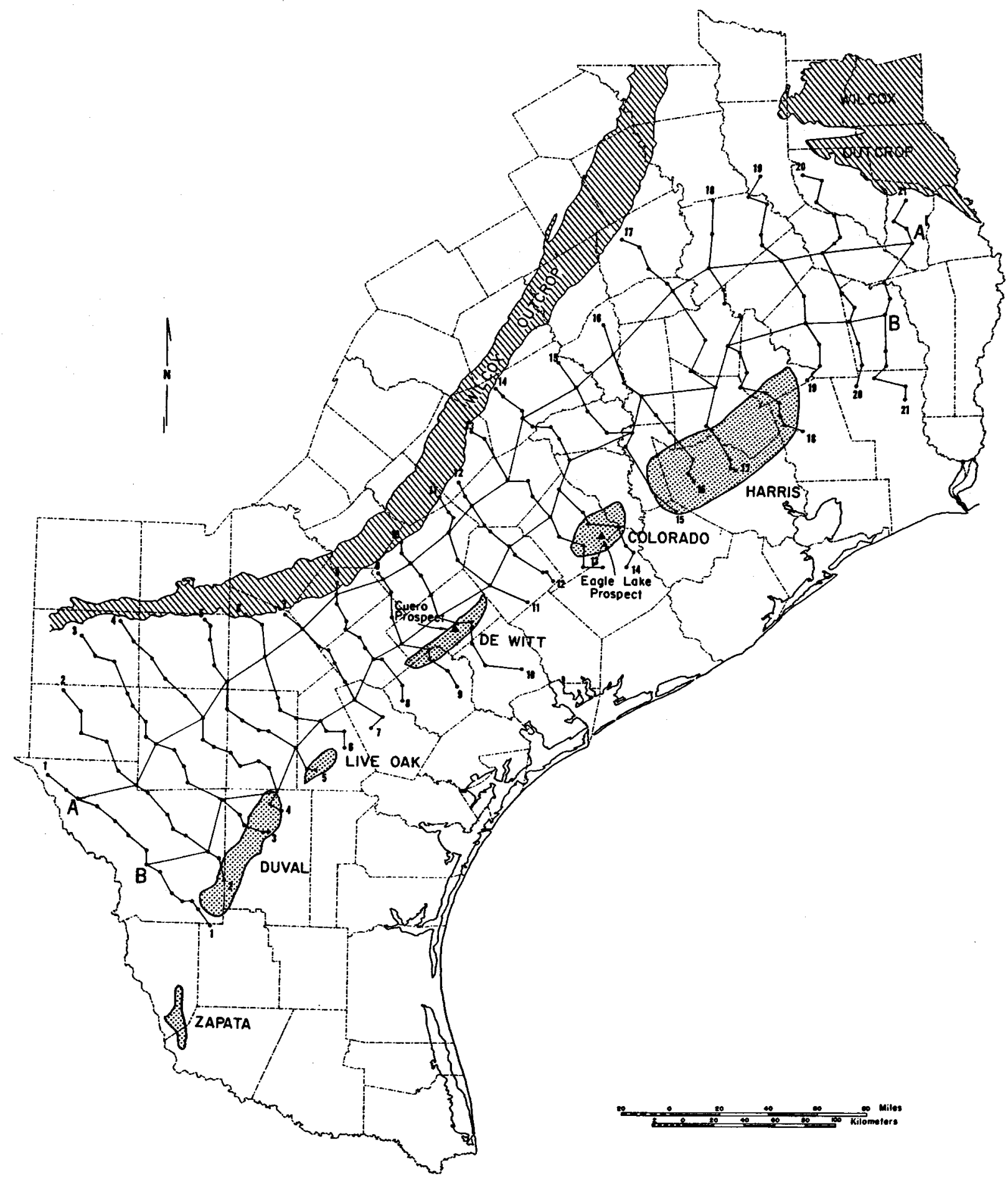

Figure 41. Wilcox geothermal fairways. 


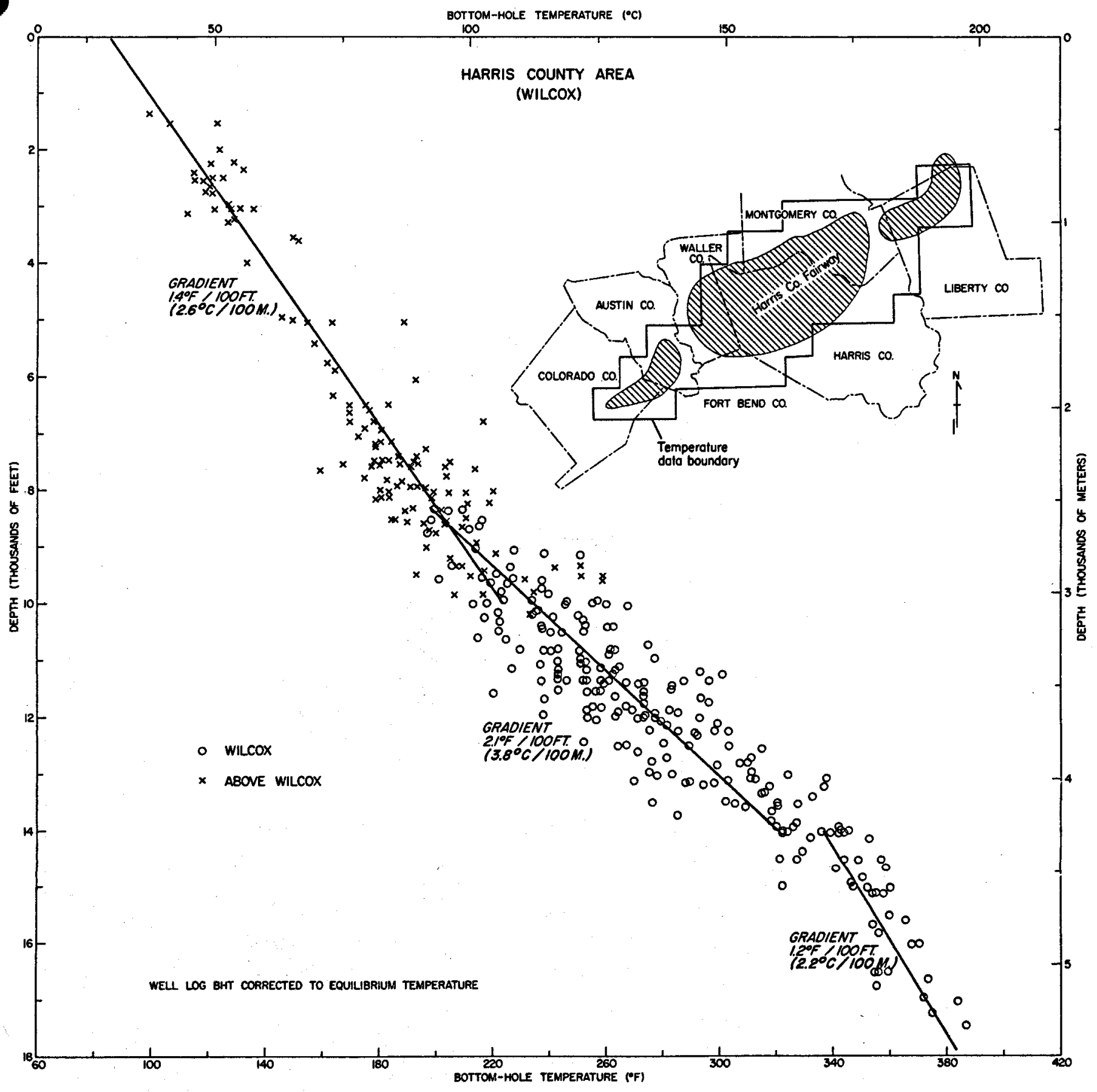

Figure 42. Temperatures and geothermal gradients for the Harris County Fairway area. 


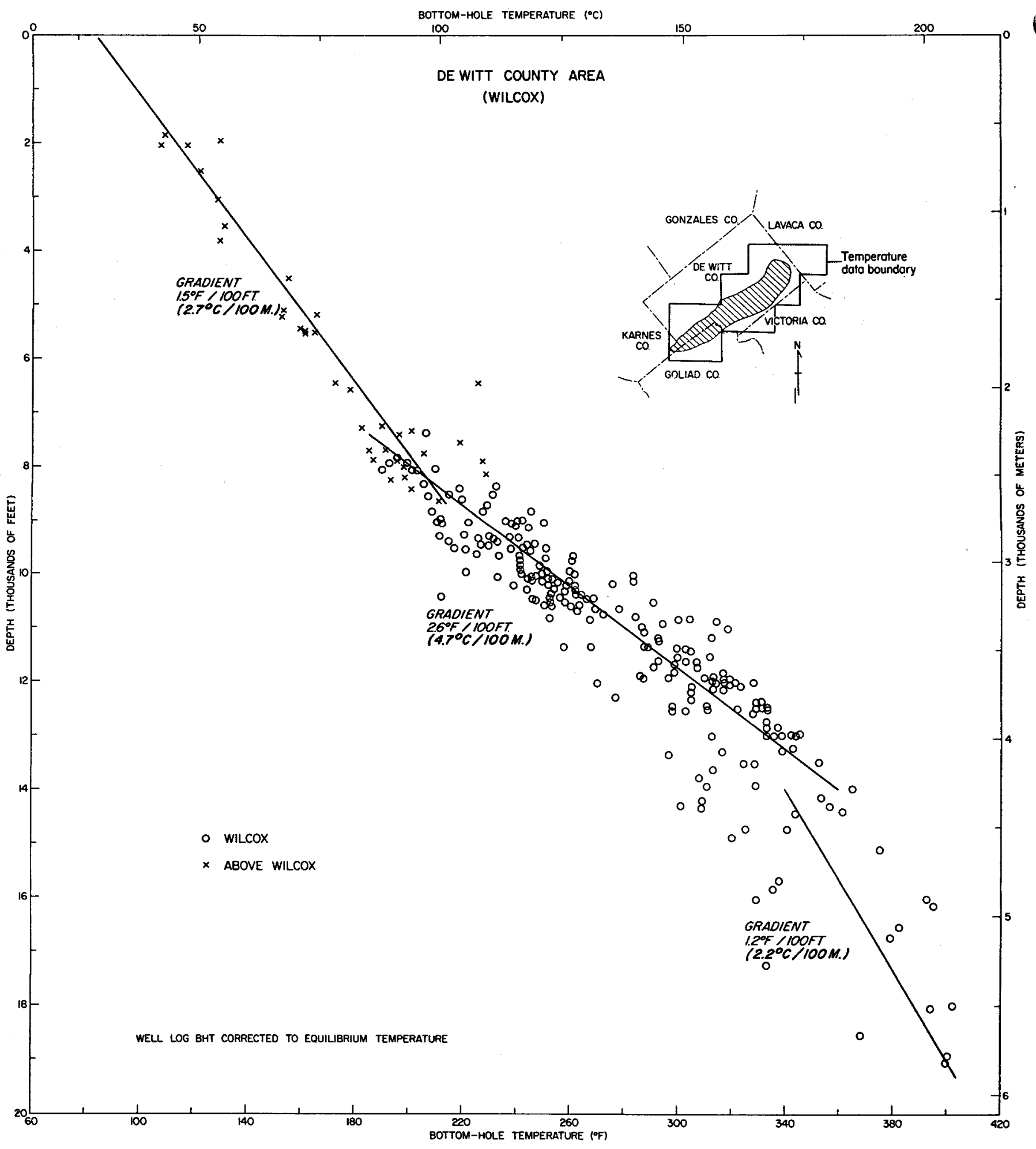

Figure 43. Temperatures and geothermal gradients for the De Witt County Fairway area. 


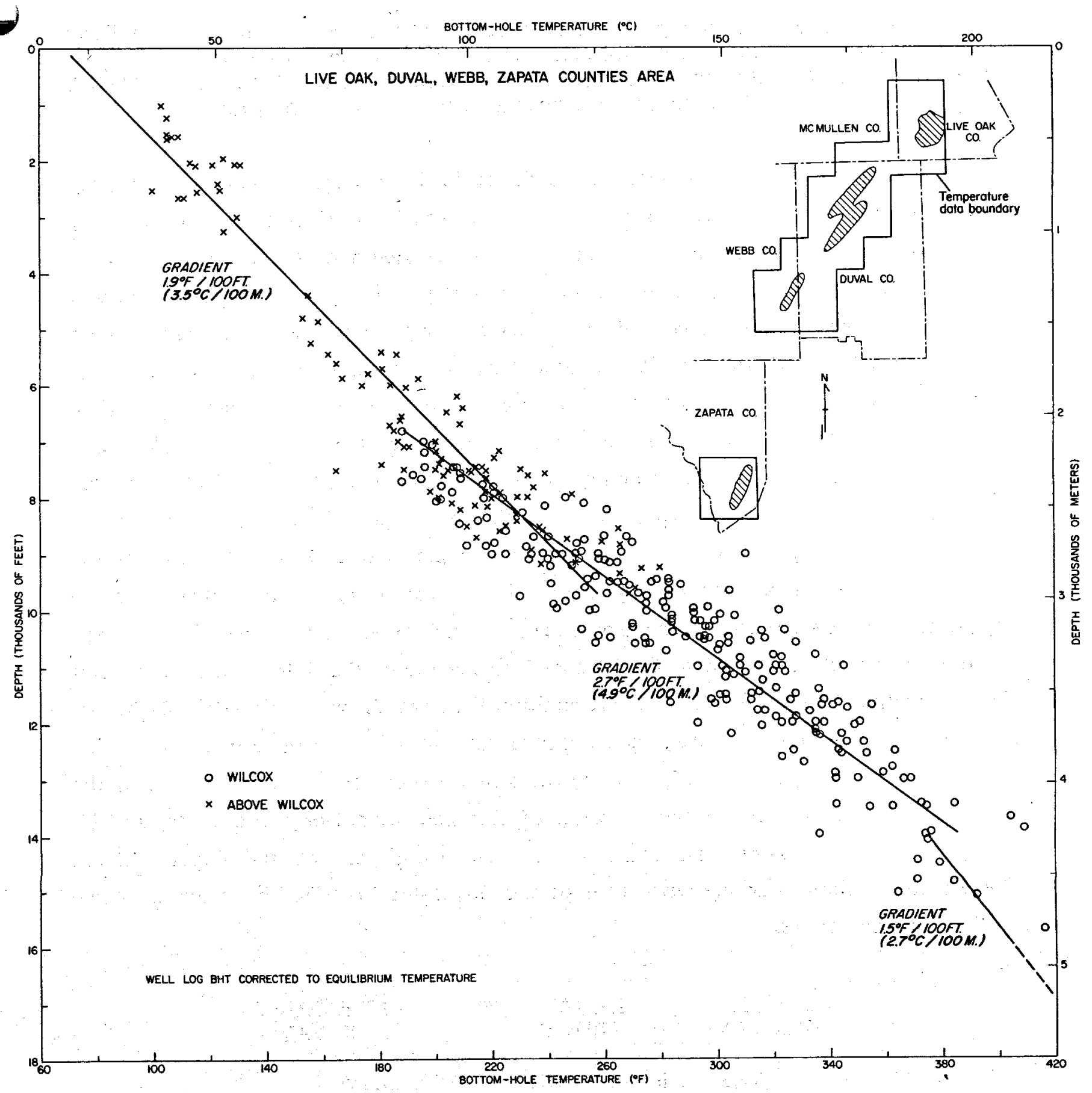

Figure 44. Temperatures and geothermal gradients for the area including parts of Live Oak, McMullen, Duval, Webb, and Zapata Counties. 
In the Zapata Fairway several prospective geothermal reservoirs in the upper Wilcox have been identified which are laterally extensive along the down-faulted side of major growth faults and which contain fluid temperatures greater than $149^{\circ} \mathrm{C}\left(300^{\circ} \mathrm{F}\right)$; however, all core analyses indicate porosity and permeability are very low.

The Zapata Fairway, elongated north-south, is located primarily in Zapata County but also extends to the south into Starr County (figs. 45 and 46 ). The fairway is approximately $43 \mathrm{~km}(27 \mathrm{mi})$ long and $10 \mathrm{~km}(6 \mathrm{mi})$ wide and has an area of $285 \mathrm{~km}^{2}$ $\left(110 \mathrm{mi}^{2}\right)$. The fairway was delineated as an area of possible geopressured geothermal reservoirs during regional study of the Wilcox Group along the Texas Gulf Coast (Bebout, Gavenda, and Gregory, 1978). Selection of this study area was based on the presence of considerable thickness of sandstone with fluid temperatures higher than $149 \mathrm{C}\left(300^{\circ} \mathrm{F}\right)$. The sandstones of the Zapata Fairway are from the upper Wilcox and are part of a general, gradual coarsening-upward sequence about $610 \mathrm{~m}(2,000 \mathrm{ft})$ thick.

This sequence was subdivided and correlated in the fairway area using many correlation markers; only five are shown in this report (figs. 47 to 49). Most of the markers are in sections with rapidly alternating sandstone and shale, some of which appear to be persistent over large areas. The two principal markers, which have been correlated throughout the Texas Gulf Coast, are the top of the Wilcox and the base of the upper Wilcox (fig. 35). Three additional markers are shown: (1) marker Z1 occurs at the top of the main sandstone-bearing interval and below an uppermost shale-rich interval (fig. 47); (2) marker $\mathrm{Z2}$ is above the sandstone units in the middle part of the upper Wilcox, which are the prime target of this geothermal-oriented study; and (3) the $\mathrm{Z3}$ marker is below the main sandstone-bearing part of the upper Wilcox. Correlation of these markers with those of the Duval and Live Oak Fairways is shown on the following chart.

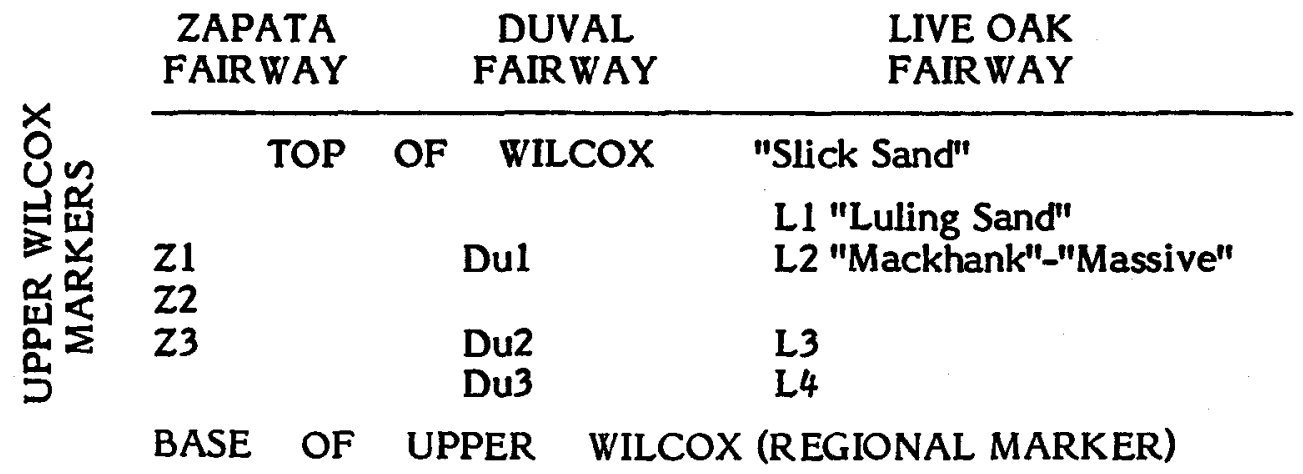


The prospective reservoirs of the Zapata Fairway are two distinct sandstone bodies which occur immediately below marker $Z 2$. These sandstones range from about $85 \mathrm{~m}(280 \mathrm{ft})$ to $200 \mathrm{~m}(620 \mathrm{ft})$ thick and occur at depths of $2,375 \mathrm{~m}(7,800 \mathrm{ft})$ to $3,090 \mathrm{~m}$ $(10,150 \mathrm{ft})$. Wells farthest downdip show some shaling out of the sandstone bodies.

The Zapata Fairway is located on the growth-faulted upper Wilcox shelf edge which includes two to three major growth faults, with displacements of up to $900 \mathrm{~m}$ $(3,000 \mathrm{ft})$ at the level of the $Z 2$ marker, and more than 10 other smaller faults. The zone of growth faulting is at least $21 \mathrm{~km}(13 \mathrm{mi})$ wide. Sedimentary units in the upper part of the Wilcox increase in thickness by a factor of three because of this contemporaneous faulting during sedimentation.

The top of geopressure, chosen where the pressure gradient exceeds the hydrostatic pressure gradient of $10.5 \mathrm{kPa} / \mathrm{m}(0.465 \mathrm{psi} / \mathrm{ft})$, occurs at an average depth of $1,829 \mathrm{~m}(6,000 \mathrm{ft})$ in Zapata County (fig. 50). However, some reservoirs as deep as $3,260 \mathrm{~m}(10,700 \mathrm{ft})$ are not geopressured. The gradient of $15.8 \mathrm{kPa} / \mathrm{m}(0.7 \mathrm{psi} / \mathrm{ft})$, referred to as the operational top of geopressure in previous reports (Bebout, Dorfman, and Agagu, 1975; Bebout, Agagu, and Dorfman, 1975; Bebout, Loucks, Bosch, and Dorfman, 1976; Bebout, Loucks, and Gregory, 1978), occurs at an average depth of $2,743 \mathrm{~m}(9,000 \mathrm{ft})$. Maximum pressure gradients of about $19.2 \mathrm{kPa} / \mathrm{m}(0.85 \mathrm{psi} / \mathrm{ft})$, determined from shut-in pressures measured during drill-stem tests, are found in a few reservoirs (fig. 50) below 3,048 $\mathrm{m}(10,000 \mathrm{ft}$ ). Maximum gradients up to $21.7 \mathrm{kPa} / \mathrm{m}$ $(0.96 \mathrm{psi} / \mathrm{ft})$ are indicated by geopressure profiles computed for individual wells (fig.51).

Temperatures of $93^{\circ} \mathrm{C}\left(200^{\circ} \mathrm{F}\right)$ and $149^{\circ} \mathrm{C}\left(300^{\circ} \mathrm{F}\right)$ occur at average depths of $2,134 \mathrm{~m}(7,000 \mathrm{ft})$ and 3,474 $\mathrm{m}(11,400 \mathrm{ft})$, respectively (fig. 52). Geothermal gradients of $2.9^{\circ} \mathrm{C} / 100 \mathrm{~m}\left(1.59^{\circ} \mathrm{F} / 100 \mathrm{ft}\right)$ are common above $2,438 \mathrm{~m}(8,000 \mathrm{ft})$ and $3.83^{\circ} \mathrm{C} / 100$ $\mathrm{m}\left(2.1^{\circ} \mathrm{F} / 100 \mathrm{ft}\right)$, below $2,438 \mathrm{~m}$.

Salinity of shallow reservoir waters varies widely from 10,000 to $75,000 \mathrm{ppm}$ $\mathrm{NaCl}$. Upper Wilcox sandstones in Zapata County have water salinities which range from 17,000 to 60,000 and average $40,000 \mathrm{ppm} \mathrm{NaCl}$, based on computations for five wells (fig. 53).

Few core analyses are available for Zapata County, but sidewall-core data for limited depth intervals in two wells are listed on the following page. 


\begin{tabular}{lccc}
$\begin{array}{l}\text { DEPTH } \\
\text { Meters }\end{array}$ & \multicolumn{1}{c}{$\begin{array}{c}\text { PERMEABILITY } \\
\text { (feet) }\end{array}$} & $\begin{array}{c}\text { POROSITY } \\
10^{-3} \mu \mathrm{m}^{2}(\mathrm{md})\end{array}$ & $\begin{array}{c}0 \text { to } 2.9 \\
\text { (ave. } 0.5)\end{array}$ \\
\hline $2,900-2,913$ & $(9,153-9,558)$ & $\begin{array}{c}17 \text { to } 21 \\
\text { (ave. 18.0) }\end{array}$ \\
$3,056-3,241$ & $(10,027-10,634)$ & $\begin{array}{c}0 \text { to } 6.6 \\
\text { (ave. } 2.0)\end{array}$ & $\begin{array}{c}18 \text { to } 22 \\
\text { (ave. 20.0) }\end{array}$ \\
3,200 & $(10,498-10,499)$ & 8 to 19 & 18 to 20
\end{tabular}




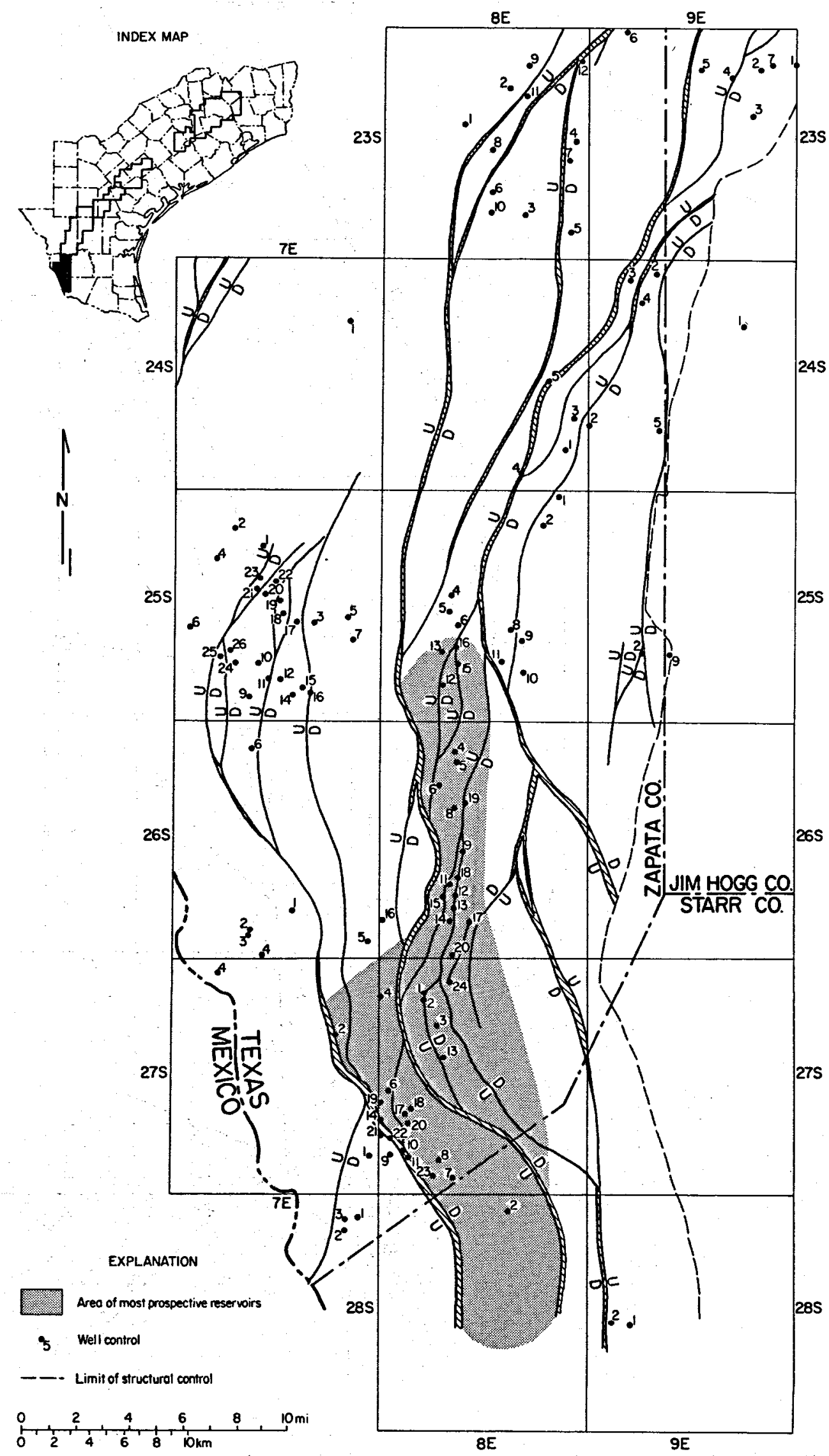

Figure 45. Well control, faults at the top of the Wilcox, and area of prospective reservoir sandstones, Zapata Fairway. 


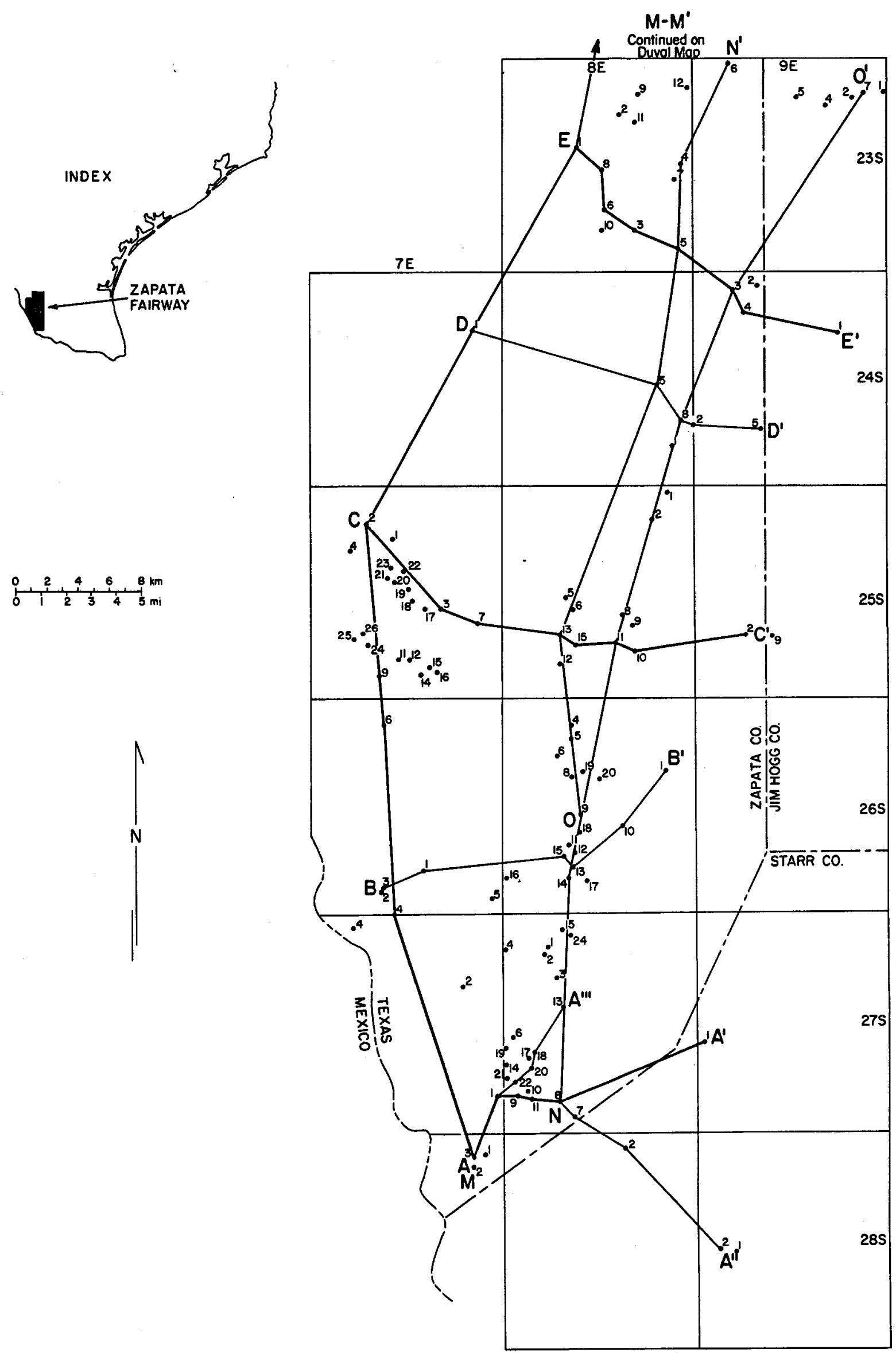

Figure 46. Well control and lines of stratigraphic and structural sections, Zapata Fairway. Heavy line indicates the section included in this report. 


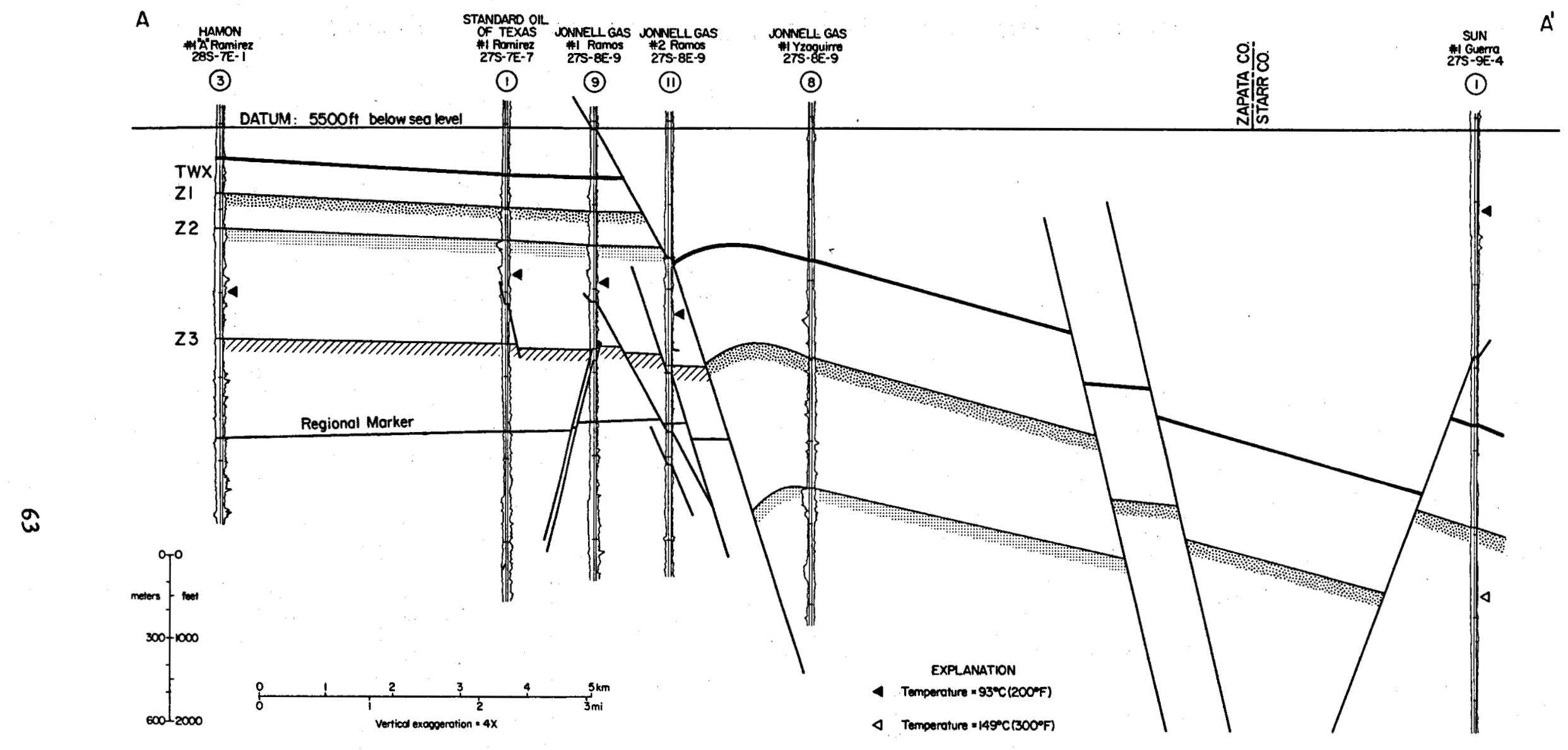

Figure 47. Structural dip section AA', southern part of the Zapata Fairway. 


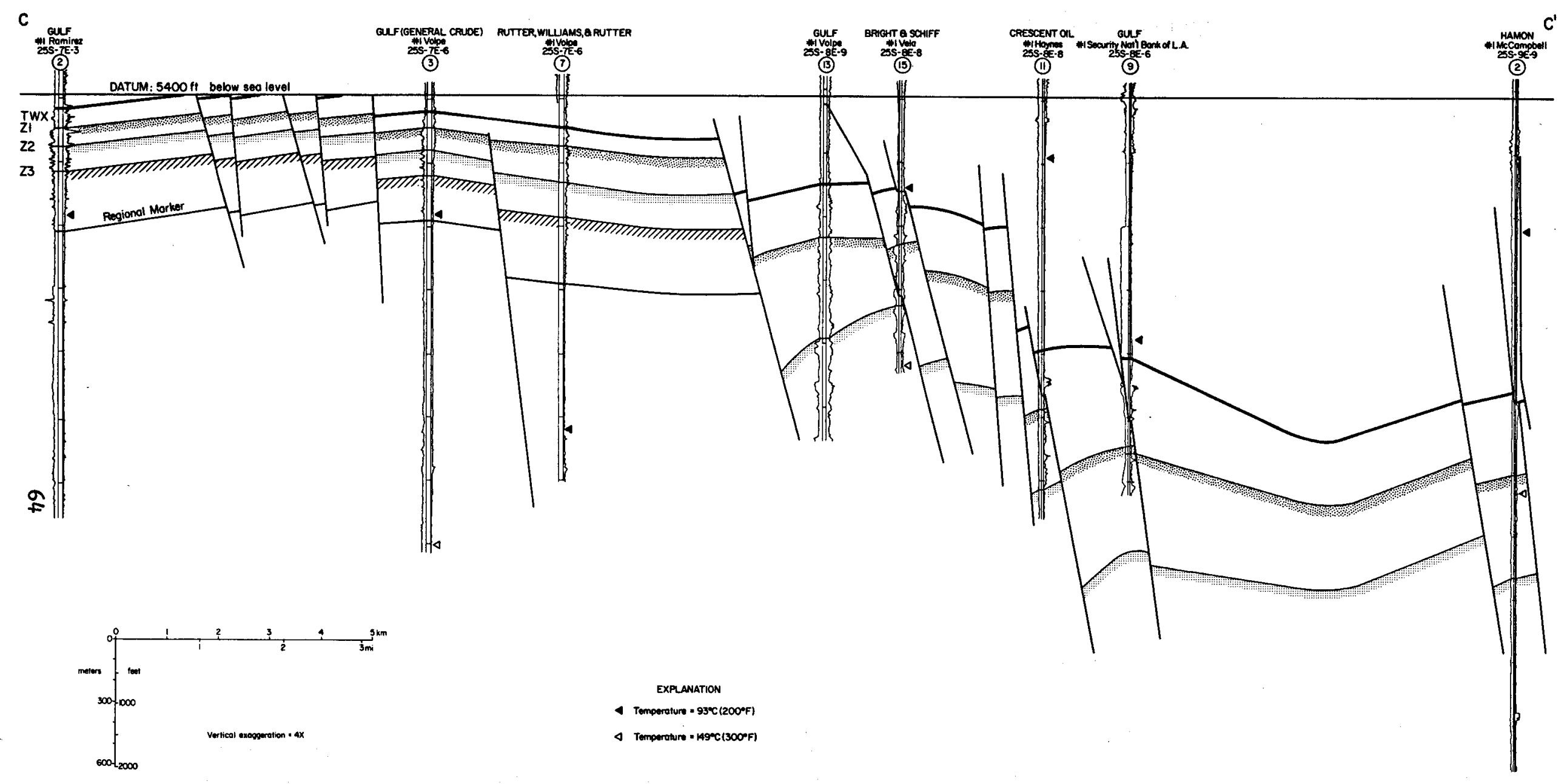

Fıgure 48. Structural dip section CC', central part of the Zapata Fairway. 


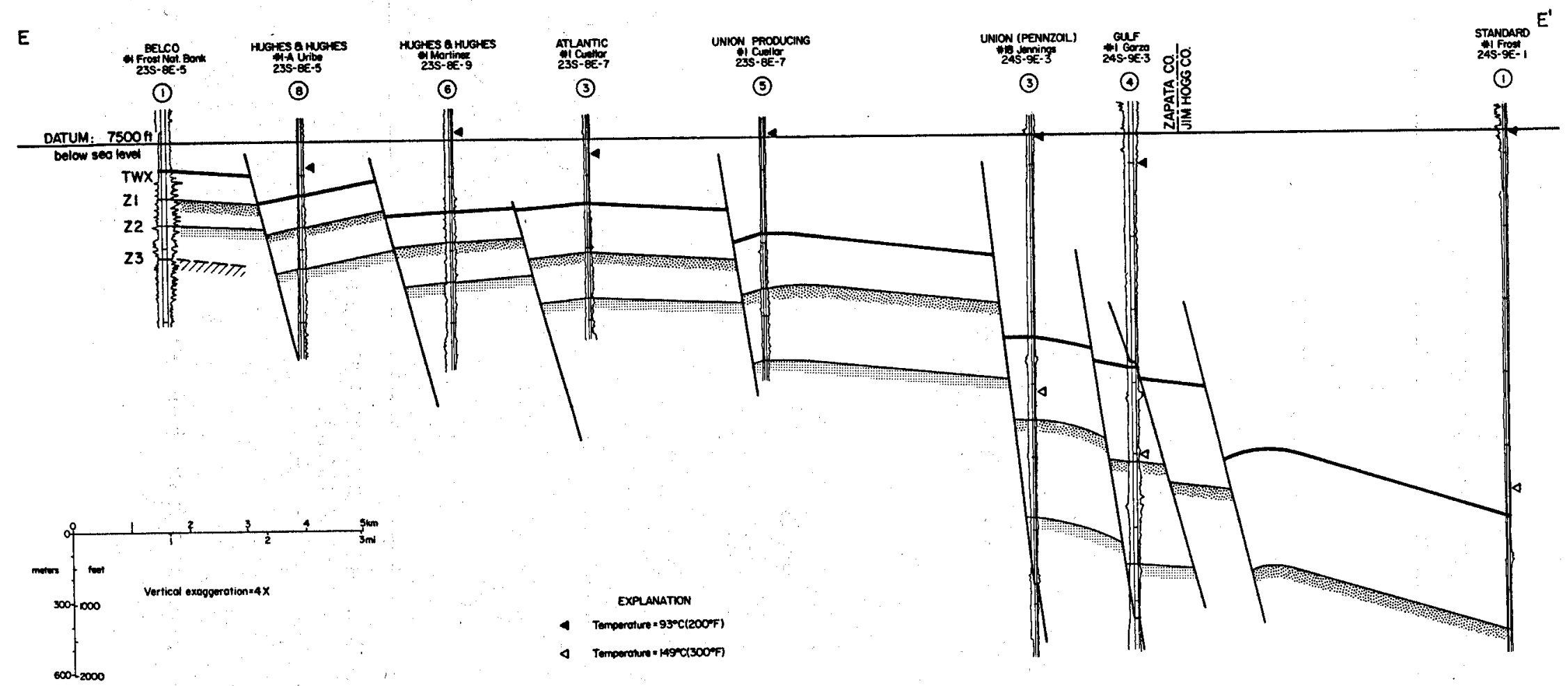

Figure 49. Structural dip section EE', northern part of the Zapata Fairway. 


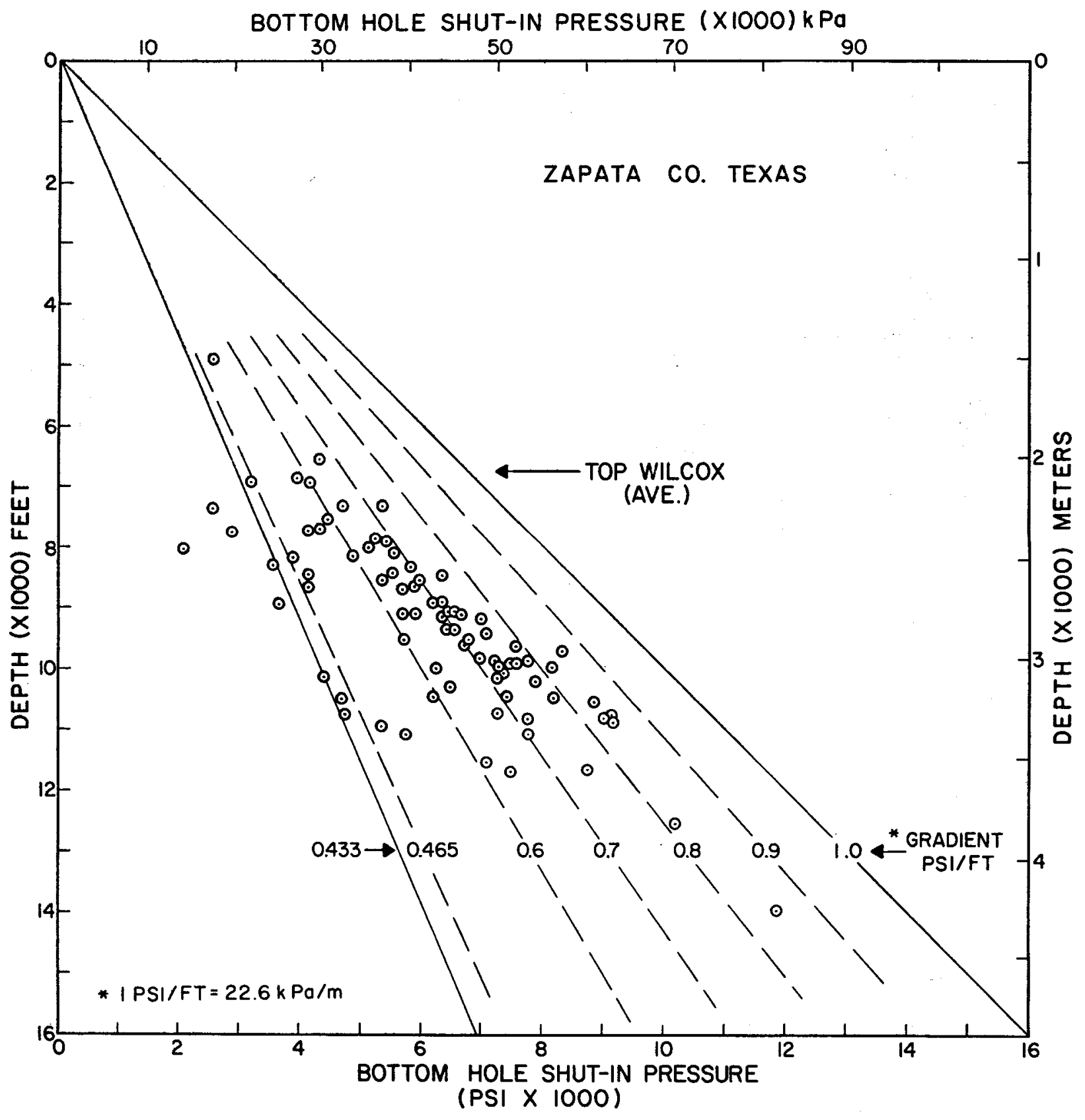

Figure 50. Bottom-hole shut-in pressures from drill stem tests as a function of depth for Zapata County. 


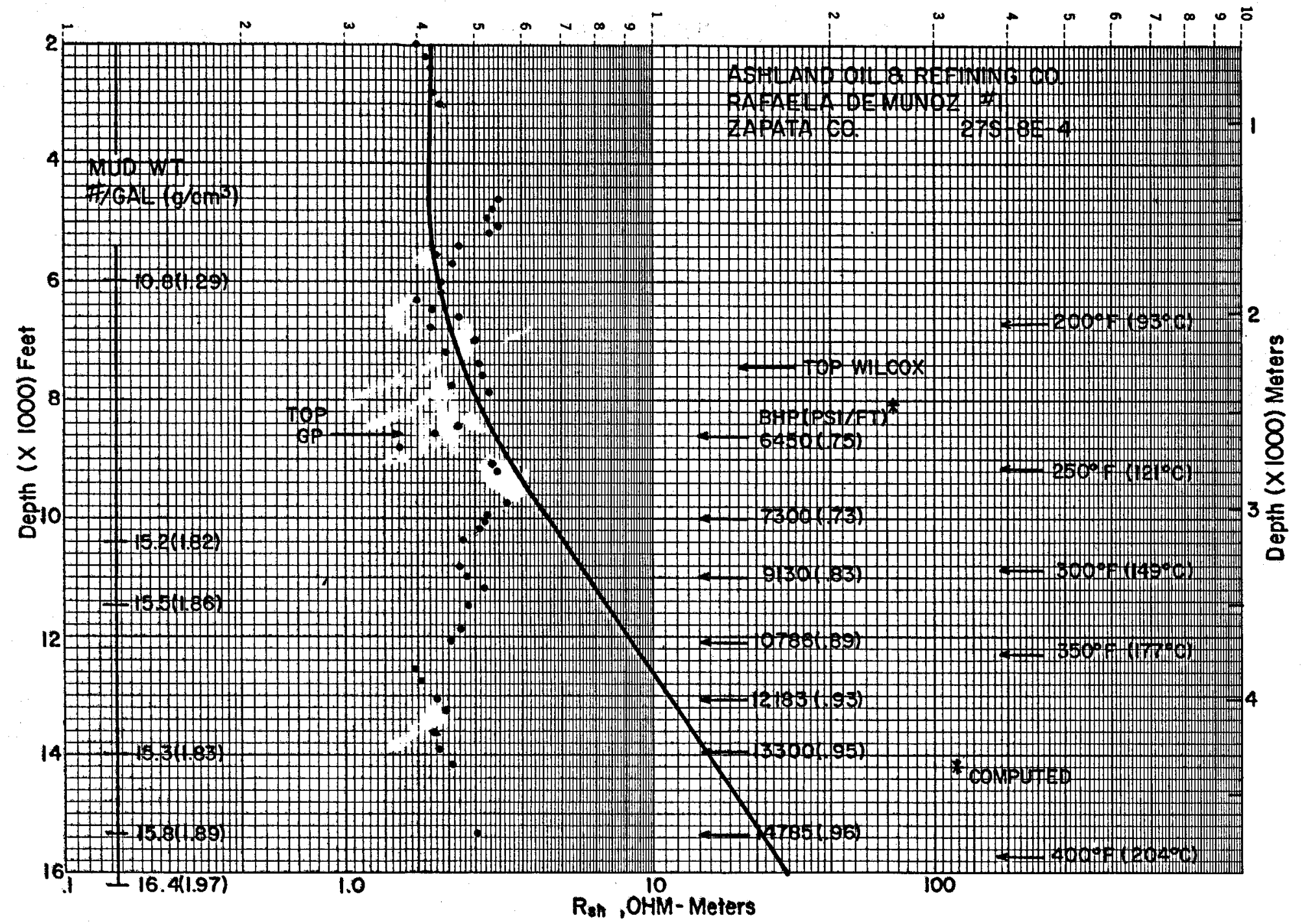

Figure 51. Top of geopressure and geopressure gradients from shale resistivity data for a well in Zapata County. 


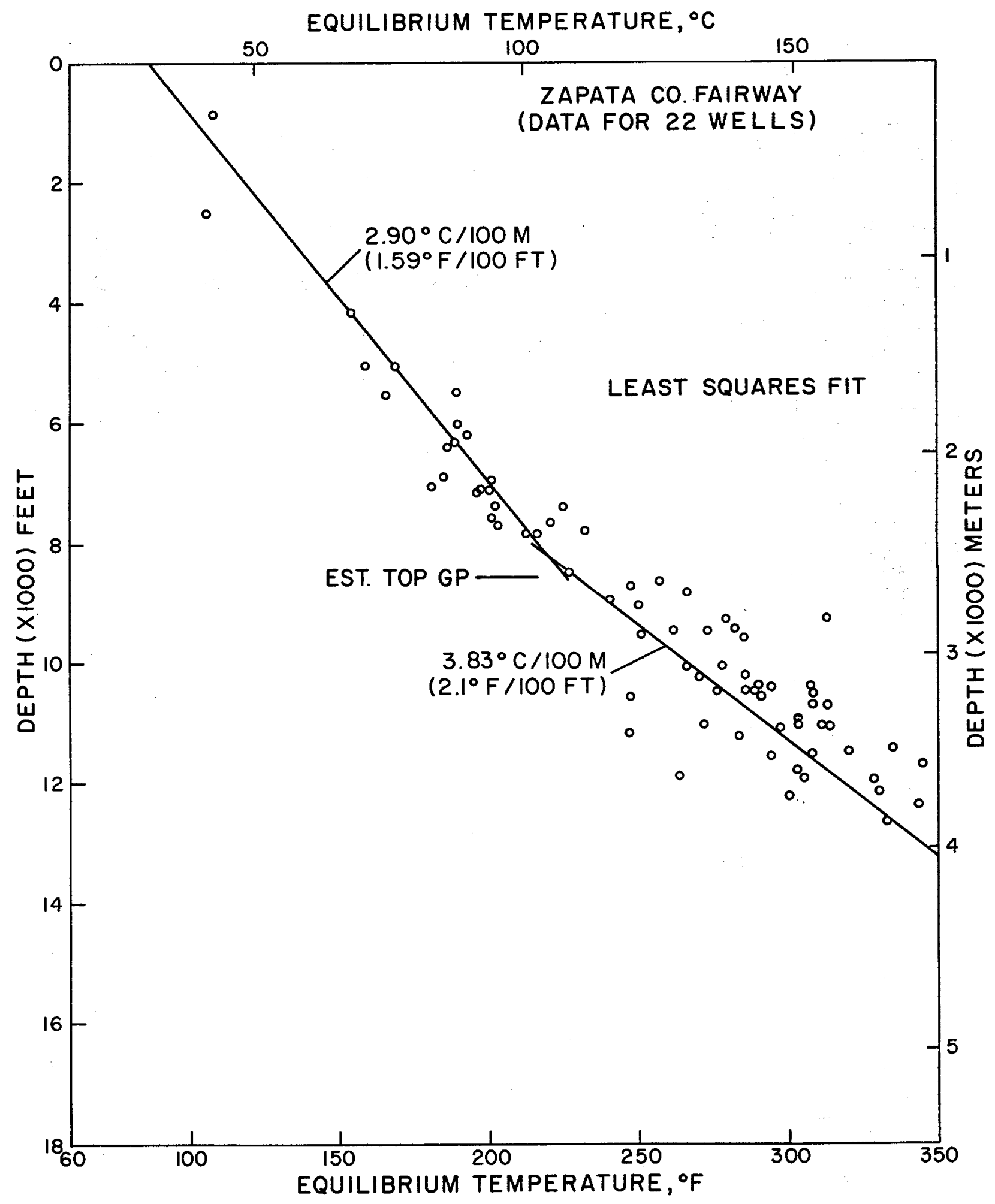

Figure 52. Temperatures and geothermal gradients for Zapata County Fairway area. 


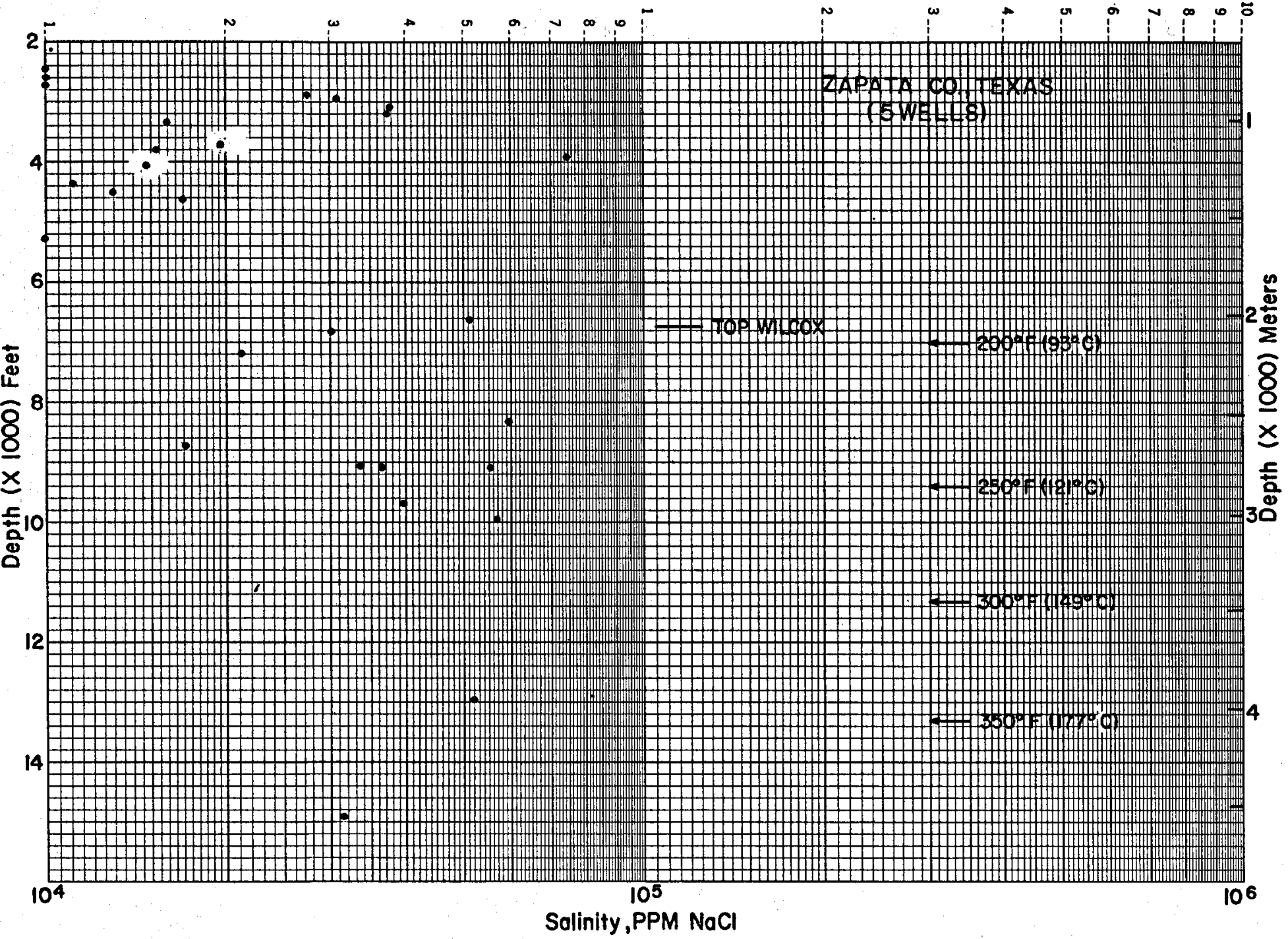

Figure 53. Salinity versus depth for five wells in Zapata County. 


\section{DUVAL FAIRWAY}

The Duval Fairway contains thick, laterally extensive sandstone units in the geopressured zone with fluid temperatures higher than $149^{\circ} \mathrm{C}\left(300^{\circ} \mathrm{F}\right)$, but porosity and permeability are generally very low.

The Duval Fairway is a southwest-trending elongate area located principally in Duval and Webb Counties but also extending south into Jim Hogg County and north into McMullen County (figs. 54 and 55). The fairway, which was originally designated as two separate fairways (Duval and Webb) as a result of the regional geopressured geothermal study of the Texas Gulf Coast Wilcox Group (Bebout, Gavenda, and Gregory, 1978), is approximately $97 \mathrm{~km}(60 \mathrm{mi})$ long and $15 \mathrm{~km}(9 \mathrm{mi})$ wide. During the course of the present study, it was determined that these two areas form one continuous stratigraphic unit of geopressured Wilcox sandstones with fluid temperatures greater than $149 \mathrm{C}\left(300^{\circ} \mathrm{F}\right)$.

In the Duval Fairway area, the prospective thick sandstones occur in the lower part of the upper Wilcox; shallower sandstones are relatively thin. The Rosita and Seven Sisters gas fields are located along this trend. In updip areas, the upper Wilcox is about $610 \mathrm{~m}(2,000 \mathrm{ft})$ thick and increases downdip to at least $1,829 \mathrm{~m}(6,000 \mathrm{ft})$. In the fairway area, the upper Wilcox was subdivided and correlated with three markers (Du1, Du2, Du3), in addition to the top and base of the upper Wilcox (fig. 56). All of these markers have been correlated into those of the Zapata and Live Oak Fairways as follows:

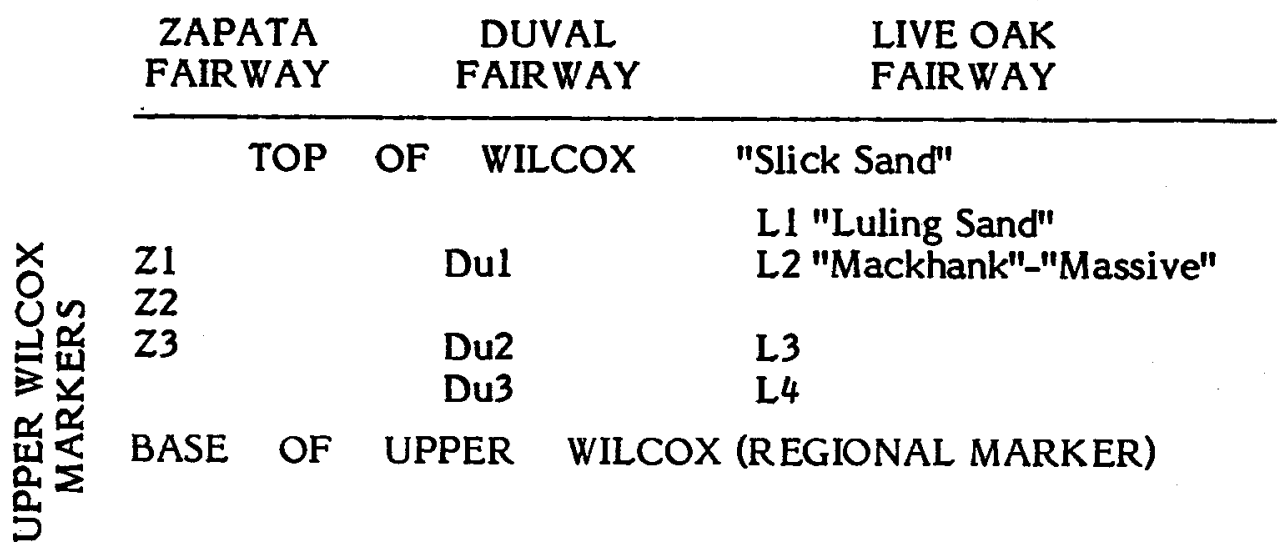


The most important marker in the Duval Fairway is the Du3 marker, which occurs at the top of the main sandstone-bearing interval. This interval, which extends downward to the regional marker at the base of the upper Wilcox, comprises very massive sandstones over a large part of the updip area of the fairway. Downdip, the sandstones are separated by thick shale sequences and are arranged into coarseningupward sequences.

The prospective sandstones of the Duval Fairway occur in the Rosita Field area at a depth of about $3,353 \mathrm{~m}(11,000 \mathrm{ft})$ and continue down to at least 4,572 $\mathrm{m}(15,000$ $\mathrm{ft}$ ) in the Du2 - Du3 interval. At least $183 \mathrm{~m}(600 \mathrm{ft})$ of sandstone in this fairway contain fluids with temperatures greater than $149^{\circ} \mathrm{C}\left(300^{\circ} \mathrm{F}\right)$. Wells farthest downdip do not show significant shaling out of sandstone bodies.

The elongate trend of the Duval Fairway approximately coincides with the belt of linear to arcuate growth faults which developed along the upper Wilcox shelf edge contemporaneous with deposition (fig. 54). This hinge-zone includes five to seven faults along any dip-oriented cross section with displacement at the level of the Du2 and Du3 markers attaining 610 to $914 \mathrm{~m}$ (2,000 to 3,000 ft). With present well control, the growth-faulted zone appears to be 18 to $23 \mathrm{~km}$ ( $11 \mathrm{ko} 14 \mathrm{mi}$ ) wide, but the downdip limit of the fairway is poorly outlined. The upper Wilcox increases in thickness across the growth-faulted zone by a factor of approximately six as a result of these growth faults. Lack of adequate well control in the Duval Fairway is a serious limitation to proper evaluation of this area as a potential geopressured geothermal prospect.

The top of geopressure, defined as the depth at which the pressure gradient exceeds $10.5 \mathrm{kPa} / \mathrm{m}(0.465 \mathrm{psi} / \mathrm{ft})$, occurs at an average depth of $2,620 \mathrm{~m}(8,600 \mathrm{ft})$ in Duval County (fig. 57); the gradient of $15.8 \mathrm{kPa} / \mathrm{m}(0.7 \mathrm{psi} / \mathrm{ft}$ ) occurs at an average depth of $3,048 \mathrm{~m}(10,000 \mathrm{ft})$. Gradients reach $20.4 \mathrm{kPa} / \mathrm{m}(0.9 \mathrm{psi} / \mathrm{ft})$ at $3,597 \mathrm{~m}(11,800$ $\mathrm{ft}$ ). Top of geopressure from shale resistivity plots for three wells in Duval County is picked between depths of 2,484 and 2,987 m (8,150 and 9,800 ft) (figs. 58, 59, and 60).

In Duval County (fig. 61) the geothermal gradient is $2.9^{\circ} \mathrm{C} / 100 \mathrm{~m}\left(1.6^{\circ} \mathrm{F} / 100 \mathrm{ft}\right)$ above $2,438 \mathrm{~m}(8,000 \mathrm{ft})$; below $2,438 \mathrm{~m}$ the gradient increases to $5.7^{\circ} \mathrm{C} / 100 \mathrm{~m}\left(3.1^{\circ}\right.$ $\mathrm{F} / 100 \mathrm{ft})$ in the geopressured zone, and is higher than the average gradient of $4.9^{\circ}$ $\mathrm{C} / 100 \mathrm{~m}$ found in the fairway area (fig. 44). A temperature of $149^{\circ} \mathrm{C}\left(300^{\circ} \mathrm{F}\right)$ occurs at an average depth of $3,277 \mathrm{~m}(10,750 \mathrm{ft})$. 
Salinities ranging from 10,000 to $55,000 \mathrm{ppm} \mathrm{NaCl}$ were calculated from water resistivities derived from the SP log from five wells in Duval County (fig. 62).

Diamond-core data from five wells in Duval County are listed below.

Depth

Meters

$2,896-2,905$

$3,208-3,213$

$3,463-3,465$

$3,613-3,668$

$3,698-3,759$

$4,206-4,267$
Permeability

Porosity

(Feet)

$10^{-3} \underset{\text { (ave.) }}{\mu \mathrm{m}^{2} \text { (md) }}$ Percent (ave.)

$(9,500-9,530)$

253

23.5

$(10,524-10,542)$

2

15

$(11,362-11,368)$

5 to 44

8 to 14

$(11,853-12,033)$

0.17

6.8

$(12,133-12,333)$

0.29

12.6

$(13,800-14,000)$

0.1

12.0 


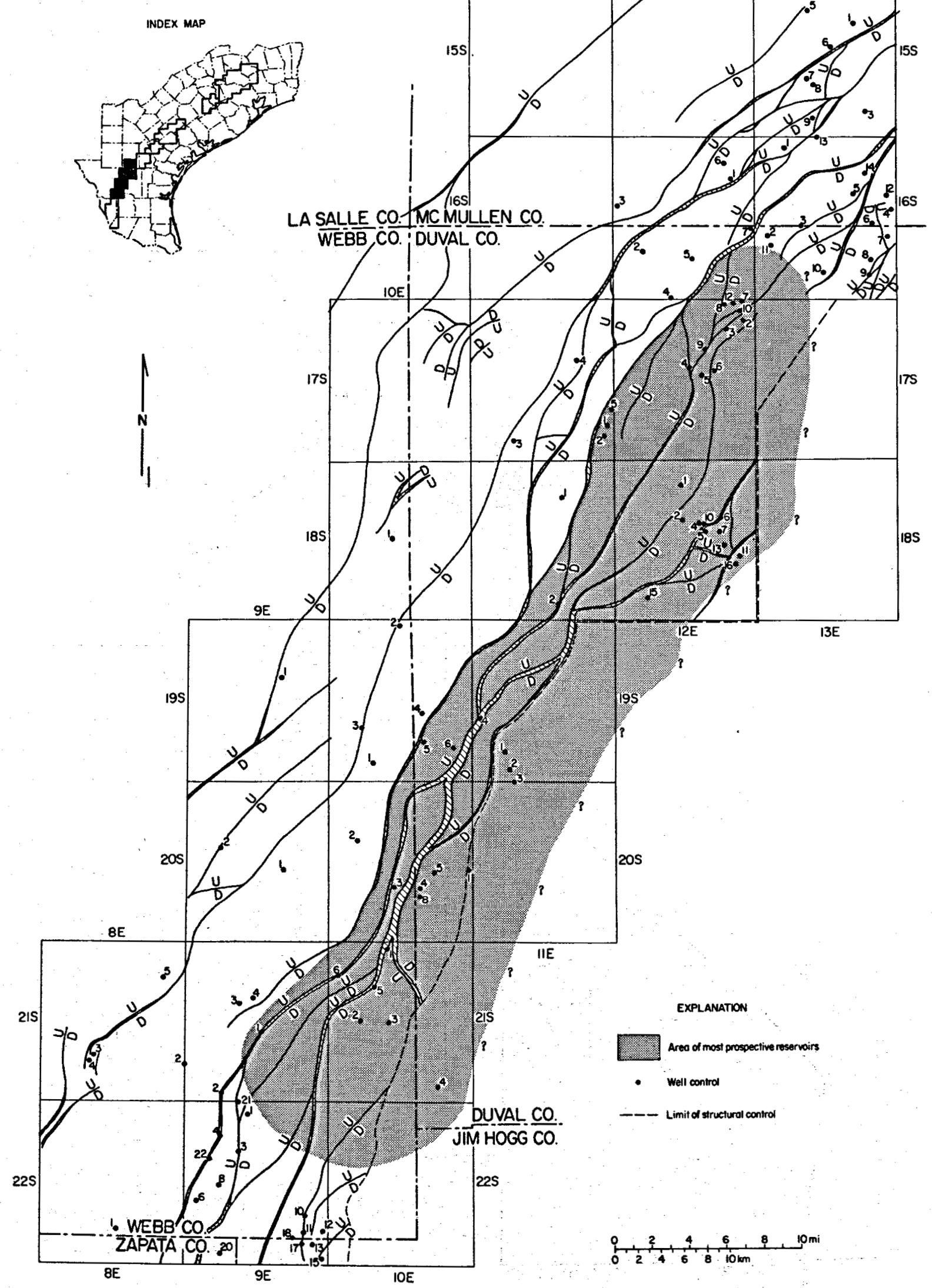

Figure 54. Well control, faults at the top of the Wilcox, and area of prospective reservoirs, Duval Fairway. 


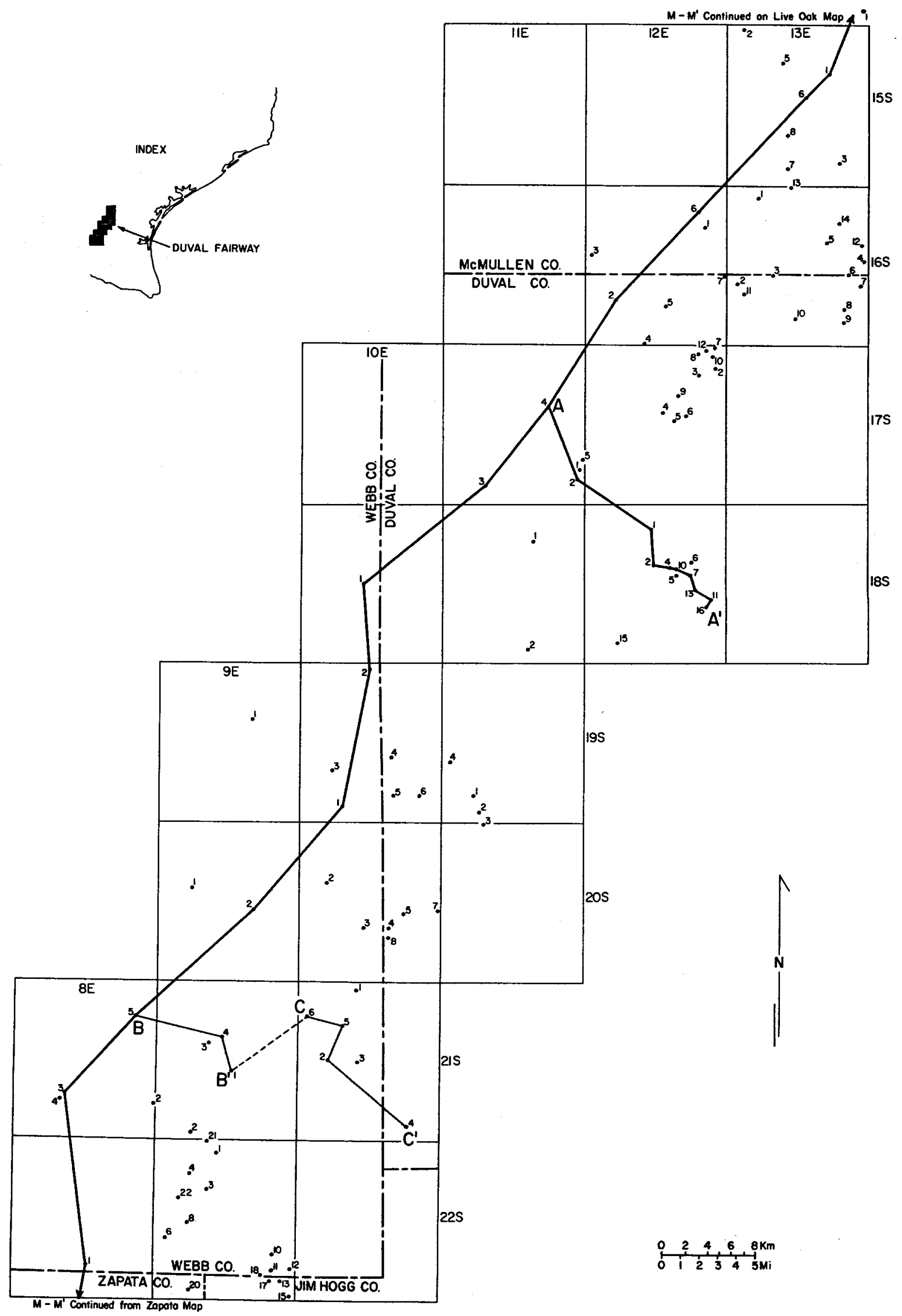

Figure 55. Well control and lines of stratigraphic and structural sections, Duval Fairway. Heavy lines indicate the section included in this report. 


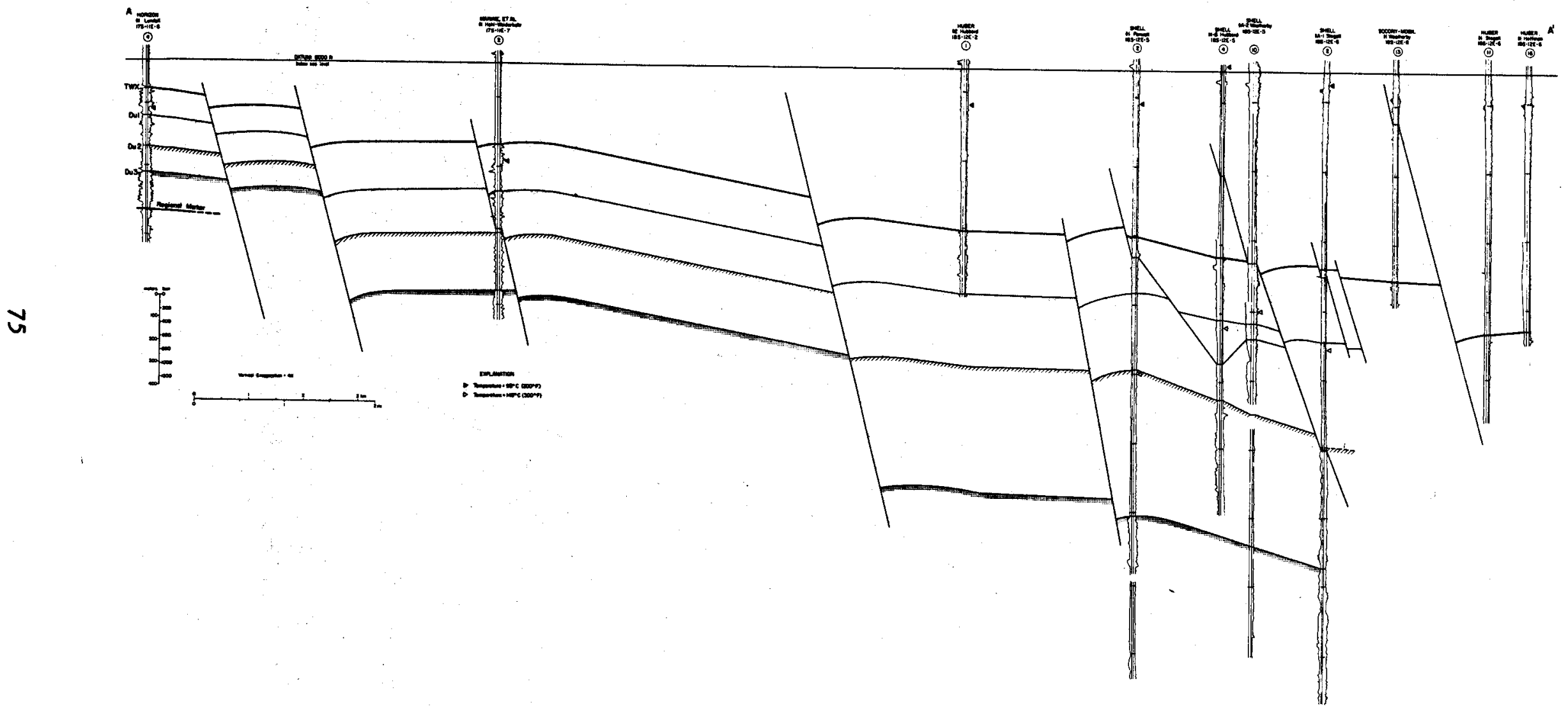

Figure 56. Structural dip section AA', Duval Fairway. 


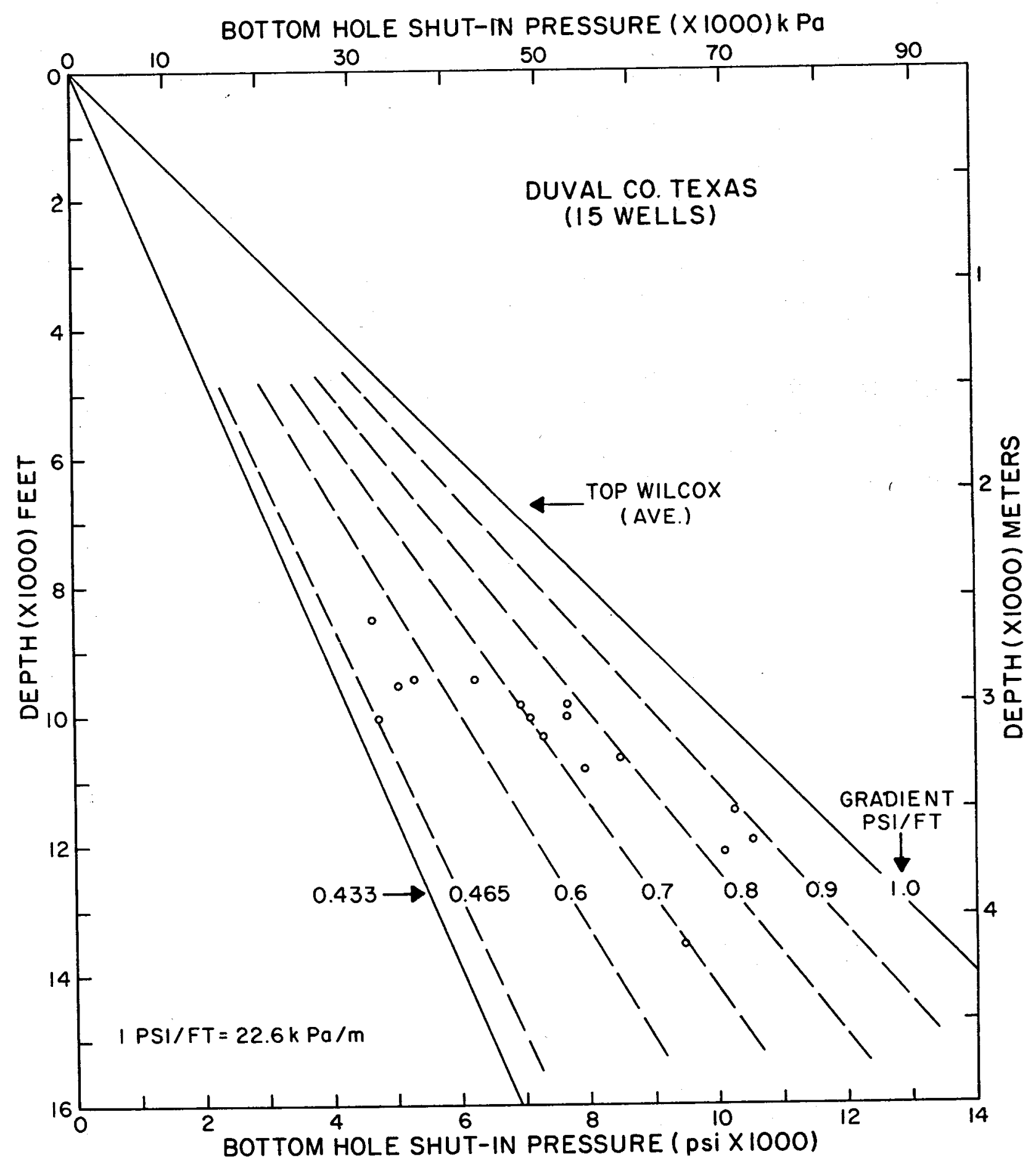

Figure 57. Bottom-hole shut-in pressures from drill stem tests as a function of depth for Duval County. 


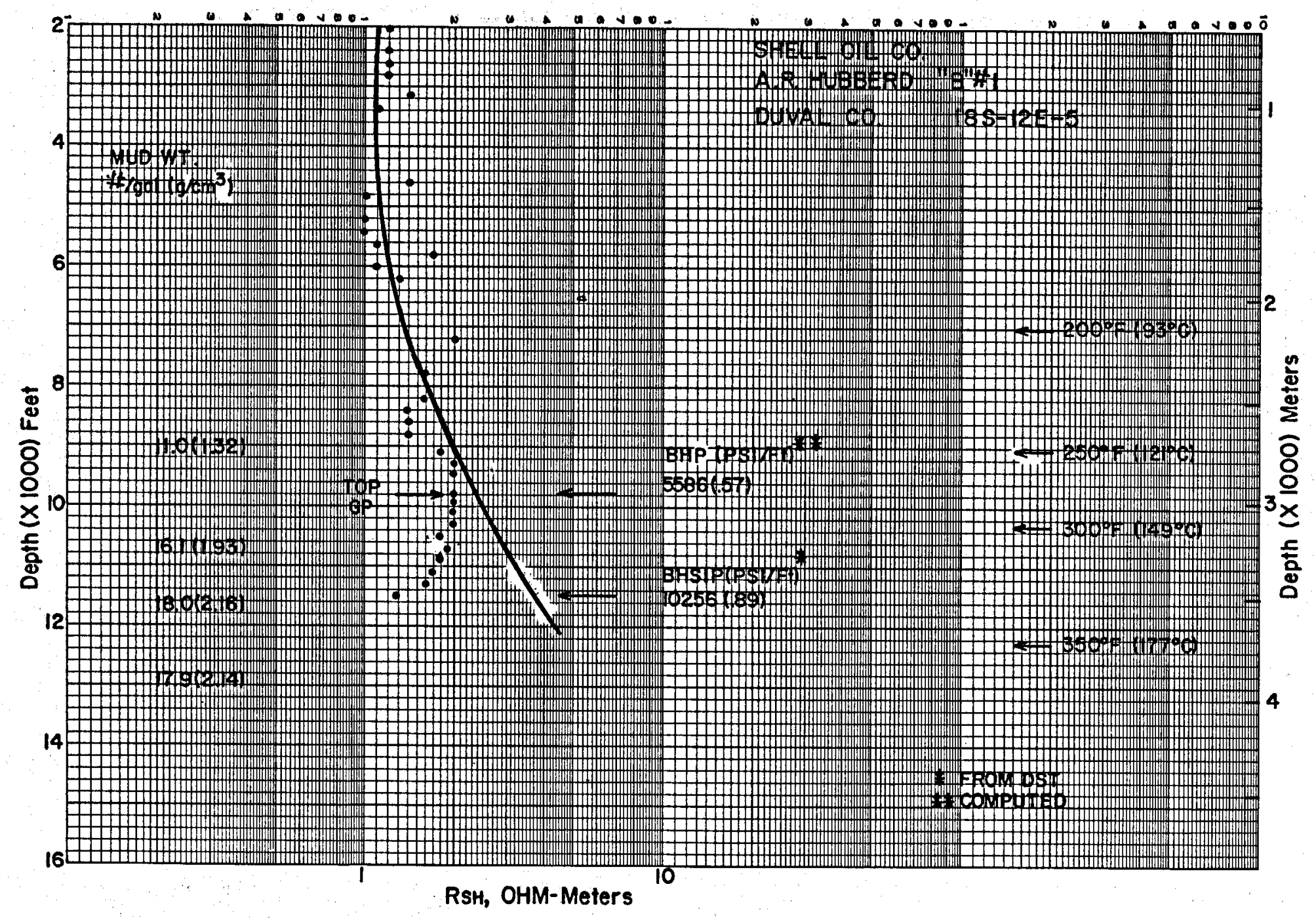

Figure 58. Top of geopressure and geopressure gradients from shale resistivity data for a well on section AA', (fig. 56), Duval County. 


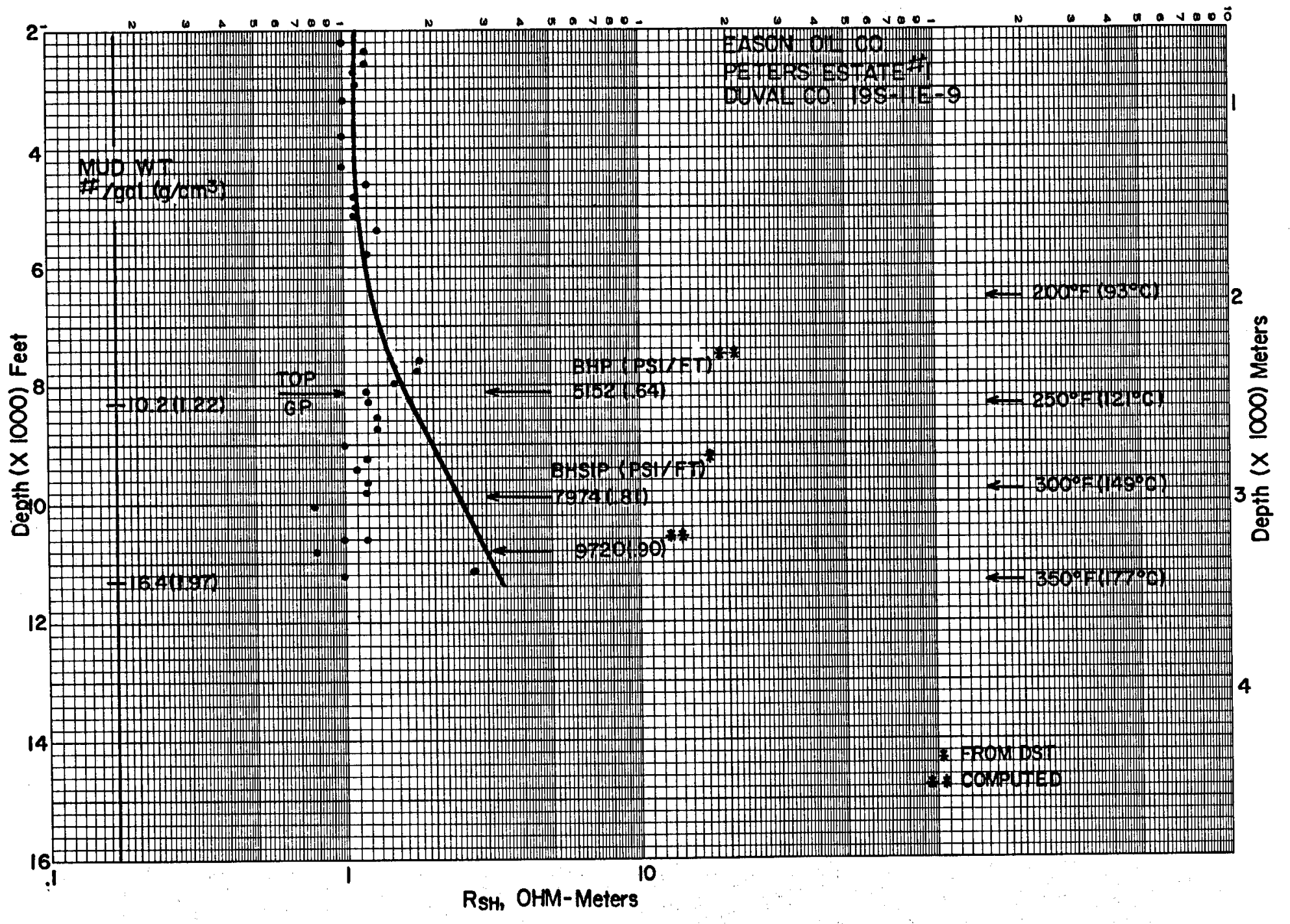

Figure 59. Top of geopressure and geopressure gradients from shale resistivity for a well in Duval County. 


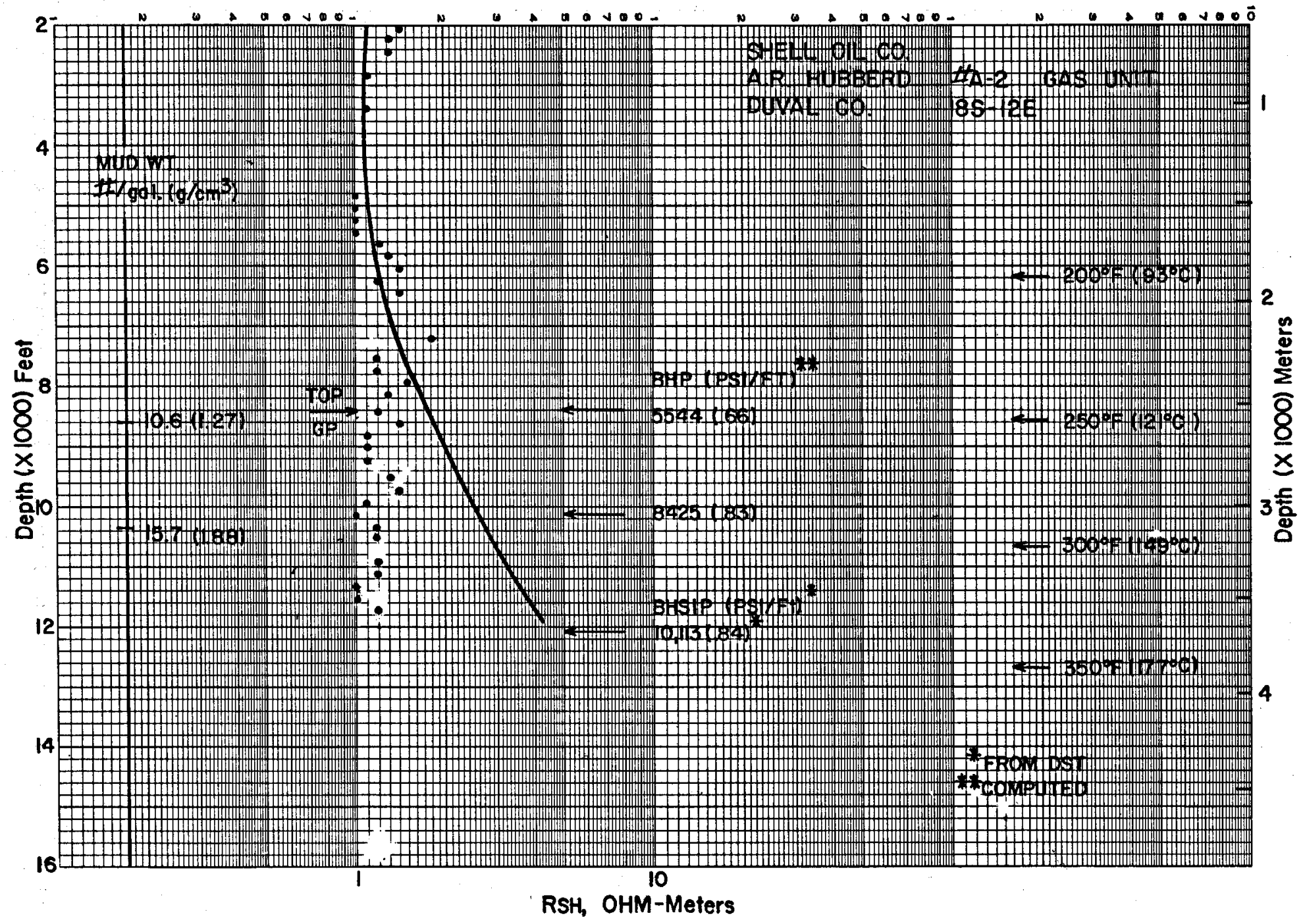

Figure 60. Top of geopressure and geopressure gradients from shale resistivity data for a well in Duval County. 


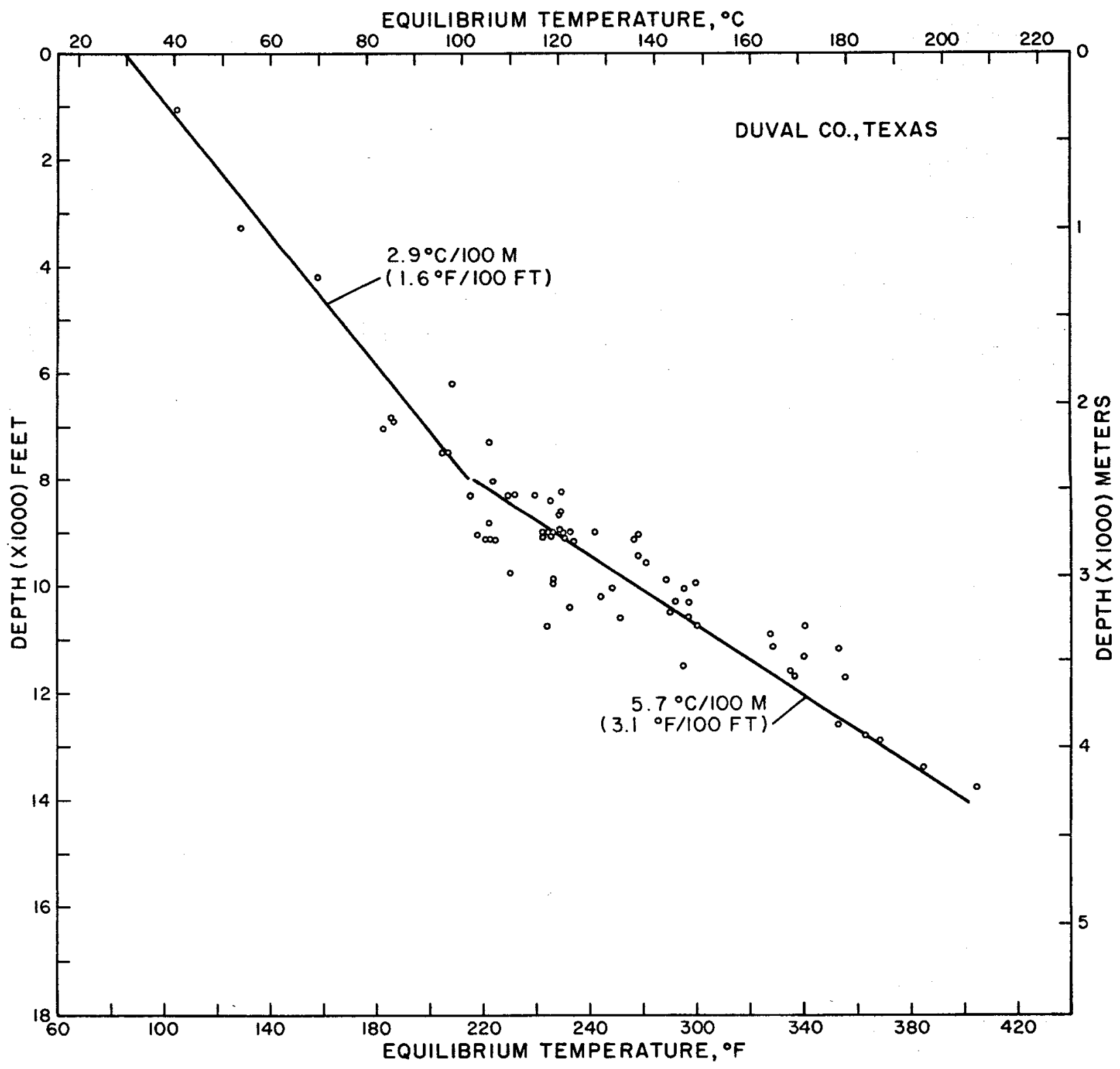

Figure 61. Temperatures and geothermal gradients for Duval County. 


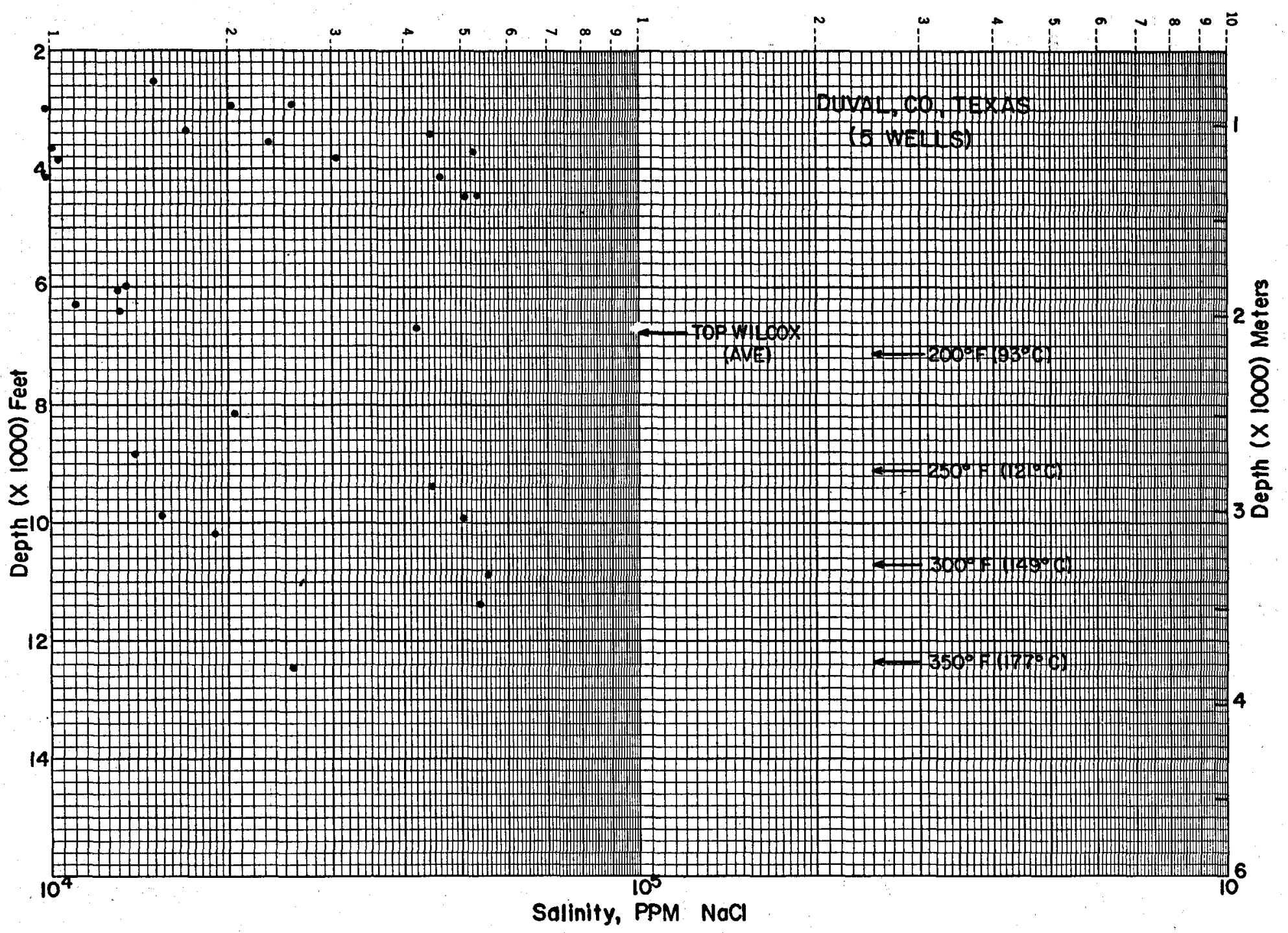

Figure 62. Salinity versus depth for five wells in Duval County. 
The Live Oak Fairway contains several laterally extensive sandstone units with a net thickness exceeding $180 \mathrm{~m}(600 \mathrm{ft})$, but temperatures are mostly lower than $149^{\circ} \mathrm{C}$ $\left(300^{\circ} \mathrm{F}\right)$, and porosity and permeability are very low.

The Live Oak Fairway, Live Oak County, Texas (figs. 63 and 64), is approximately $21 \mathrm{~km}(13 \mathrm{mi})$ long and $10 \mathrm{~km}(6 \mathrm{mi})$ wide and has an area of approximately $180 \mathrm{~km}^{2}$ $\left(70 \mathrm{mi}^{2}\right)$. This fairway was delineated as an area of possible geopressured geothermal reservoirs through the regional study of the Texas Gulf Coast Wilcox Group (Bebout and others, 1978) on the basis of the presence of thick, laterally extensive sandstones with fluid temperatures greater than $149^{\circ} \mathrm{C}\left(300^{\circ} \mathrm{F}\right)$ in the geopressured zone.

Most of the prospective sandstones occur in the upper Wilcox; updip the upper Wilcox is about $400 \mathrm{~m}(1,300 \mathrm{ft})$ thick and downdip, where only the uppermost part of the upper Wilcox has been penetrated, it is at least $900 \mathrm{~m}(3,000 \mathrm{ft})$ thick (figs. 65 through 67). Important fields producing hydrocarbons from the upper Wilcox in this area include the Tom Lyne Field updip and the Katz-Slick Field downdip. In the Live Oak Fairway, four markers were used to subdivide the upper Wilcox; two of the markers ( $L 1$ and L2) are near the top of the Wilcox and have been correlated throughout the fairway, and two lower markers (L3 and L4) have been identified only in updip wells. Additional markers are the top of the Wilcox and base of the upper Wilcox regional markers.

Several of the correlation markers identified during this study have been recognized by industry and have been assigned names; the correlation of these markers with industry names and with the correlation markers of the other fairways is as follows:

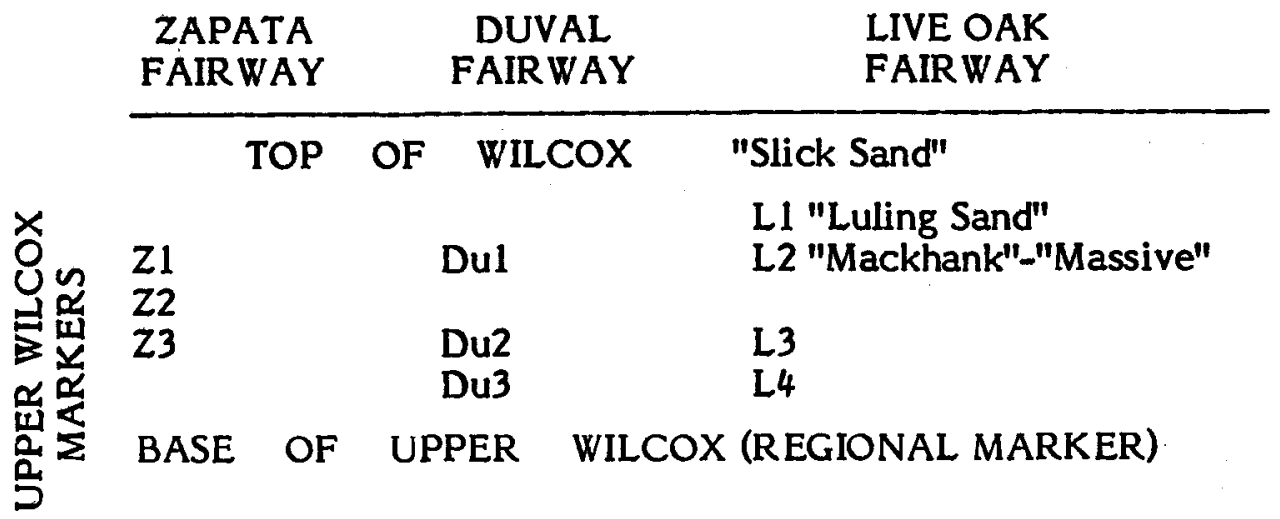


Only the top of the upper Wilcox has been penetrated in downdip parts of the Live Oak Fairway. Together, the sandstones from the top of the Wilcox to the $\mathrm{L2}$ marker comprise the prospective reservoirs for the Live Oak Fairway (figs. 68 through 70). Most of the sandstone units occur as complex coarsening-upward sequences. The well farthest downdip suggests appreciable shaling out of sandstones at the very top of the Wilcox.

The $\mathrm{L} 2$ sandstone is $90 \mathrm{~m}$ ( $300 \mathrm{ft}$ ) thick in updip wells and has not been penetrated downdip. Marker 44 occurs at the top of another section containing sandstones and shales developed into coarsening-upward sequences, but in that section the sandstone units are thicker than in the overlying interval.

In the downdip parts of the Live Oak Fairway, the prospective sandstone-bearing interval begins at the top of the Wilcox at approximately $2,800 \mathrm{~m}(9,200 \mathrm{ft})$ to $3,230 \mathrm{~m}$ $(10,600 \mathrm{ft})$, and extends downward at least $1,220 \mathrm{~m}(4,000 \mathrm{ft})$ and possibly as much as $2,440 \mathrm{~m}(8,000 \mathrm{ft})$. However, only the upper part of this interval has been penetrated, where it contains $180 \mathrm{~m}(600 \mathrm{ft})$ of sandstone.

The Live Oak Fairway is developed in an area characterized by a series of arcuate growth faults, probably developed at the margin of a rapidly prograding lobate delta (fig. 64). The growth-faulted zone has a total known width of about $25 \mathrm{~km}$ (16 $\mathrm{mi}$ ), but the downdip margin is poorly known and the largest faults occur in the central and downdip areas. Approximately nine faults are present across this zone. Passing from the updip to the downdip margin of the growth-faulted zone, the upper part of the Wilcox (the "Slick" sands) increases in thickness from $43 \mathrm{~m}$ (140 ft) to $430 \mathrm{~m}(1,400$ $\mathrm{ft}$ ) indicating an unusually large growth factor of 10 caused by faulting and subsidence contemporaneous with sedimentation (figs. 68 through 70 ).

The top of geopressure, where geopressure gradients exceed $10.5 \mathrm{kPa} / \mathrm{m}(0.465$ psi/ft), occurs from 2,134 to $2,438 \mathrm{~m}(7,000$ to $8,000 \mathrm{ft})$, based on bottom-hole shut-in pressures from drill stem tests for 26 wells in Live Oak County (fig. 71). A gradient of $15.8 \mathrm{kPa} / \mathrm{m}(0.7 \mathrm{psi} / \mathrm{ft})$ occurs at an average depth of $3,033 \mathrm{~m}(9,950 \mathrm{ft})$. The maximum pressure gradient observed was about $17.6 \mathrm{kPa} / \mathrm{m}(0.78 \mathrm{psi} / \mathrm{ft})$ at $3,185 \mathrm{~m}$ $(10,450 \mathrm{ft})$.

Top of geopressure picked from shale-resistivity plots (figs. 72 through 74 ) for three wells on the cross section $\mathrm{AA}^{\prime}$ (fig. 75) demonstrate that some of these wells were not geopressured. Tops of isopiestic gradient surfaces along cross section AA' show that only the two wells farthest downdip penetrate highly geopressured zones (fig. 75). 
The geothermal gradient shallower than $2,740 \mathrm{~m}(8,990 \mathrm{ft})$ in the Live Oak County (fig. 76$)$ is $3.5^{\circ} \mathrm{C} / 100 \mathrm{~m}\left(1.9^{\circ} \mathrm{F} / 100 \mathrm{ft}\right)$. Deeper than $2,740 \mathrm{~m}$ in the geopressured zone the gradient increases to $5.8^{\circ} \mathrm{C} / 100 \mathrm{~m}\left(3.2^{\circ} \mathrm{F} / 100 \mathrm{ft}\right)$, higher than the average gradient of $4.9^{\circ} \mathrm{C} / 100 \mathrm{~m}\left(2.7^{\circ} \mathrm{F} / 100 \mathrm{ft}\right)$ for the larger fairway area including parts of Live Oak, McMullen, Duval, Webb, and Zapata Counties (fig. 77). Temperature-versus-depth plots and isothermal surfaces of $93^{\circ} \mathrm{C}\left(200^{\circ} \mathrm{F}\right), 121^{\circ} \mathrm{C}$ $\left(250^{\circ} \mathrm{F}\right)$, and $149^{\circ} \mathrm{C}\left(300^{\circ} \mathrm{F}\right)$ are shown for control wells in cross section $\mathrm{AA}^{\prime}$ (fig. 75).

Salinities of formation waters in the six wells on cross section $\mathrm{AA}^{\prime}$ increase to a maximum value of $150,000 \mathrm{ppm} \mathrm{NaCl}$ (figs. 78 and 75) at a depth of $1,341 \mathrm{~m}(4,400 \mathrm{ft}$ ). Limited data showing low salinities between 1,341 and 2,377 $\mathrm{m}(4,400$ and 7,800 ft) are of doubtful quality. Below $2,377 \mathrm{~m}$, salinities decrease to an average value of about $38,000 \mathrm{ppm} \mathrm{NaCl}$ at 3,353 $\mathrm{m}(11,000 \mathrm{ft})$.

Porosities computed from formation-resistivity factors for six wells on cross section $\mathrm{AA}^{\prime}$ (figs. 79 and 75$)$ decrease from about 35 percent at $914 \mathrm{~m}(3,000 \mathrm{ft})$ to about 10 percent at 3,353 $\mathrm{m}(11,000 \mathrm{ft})$. Limited diamond-core data from two wells in Live Oak County show an average porosity of 21 percent and permeability of $20 \times 10^{-3}$ $\mu \mathrm{m}^{2}(20 \mathrm{md})$ in the $5-\mathrm{m}$ sandstone interval from 2,433 to $2,438 \mathrm{~m}(7,982$ to 8,000 ft). From 3,191 to 3,194 $\mathrm{m}$ the porosity and permeability average 16 percent and $8 \mathrm{x}$ $10^{-3} \mu \mathrm{m}^{2}(8 \mathrm{md})$. Sidewall cores from 3,048 to $3,658 \mathrm{~m}(10,000$ to $12,000 \mathrm{ft})$ indicated a porosity range of 17 to 24 percent and a permeability range of $5 \times 10^{-3} \mu \mathrm{m}^{2}$ (5 to $40 \mathrm{md})$. 


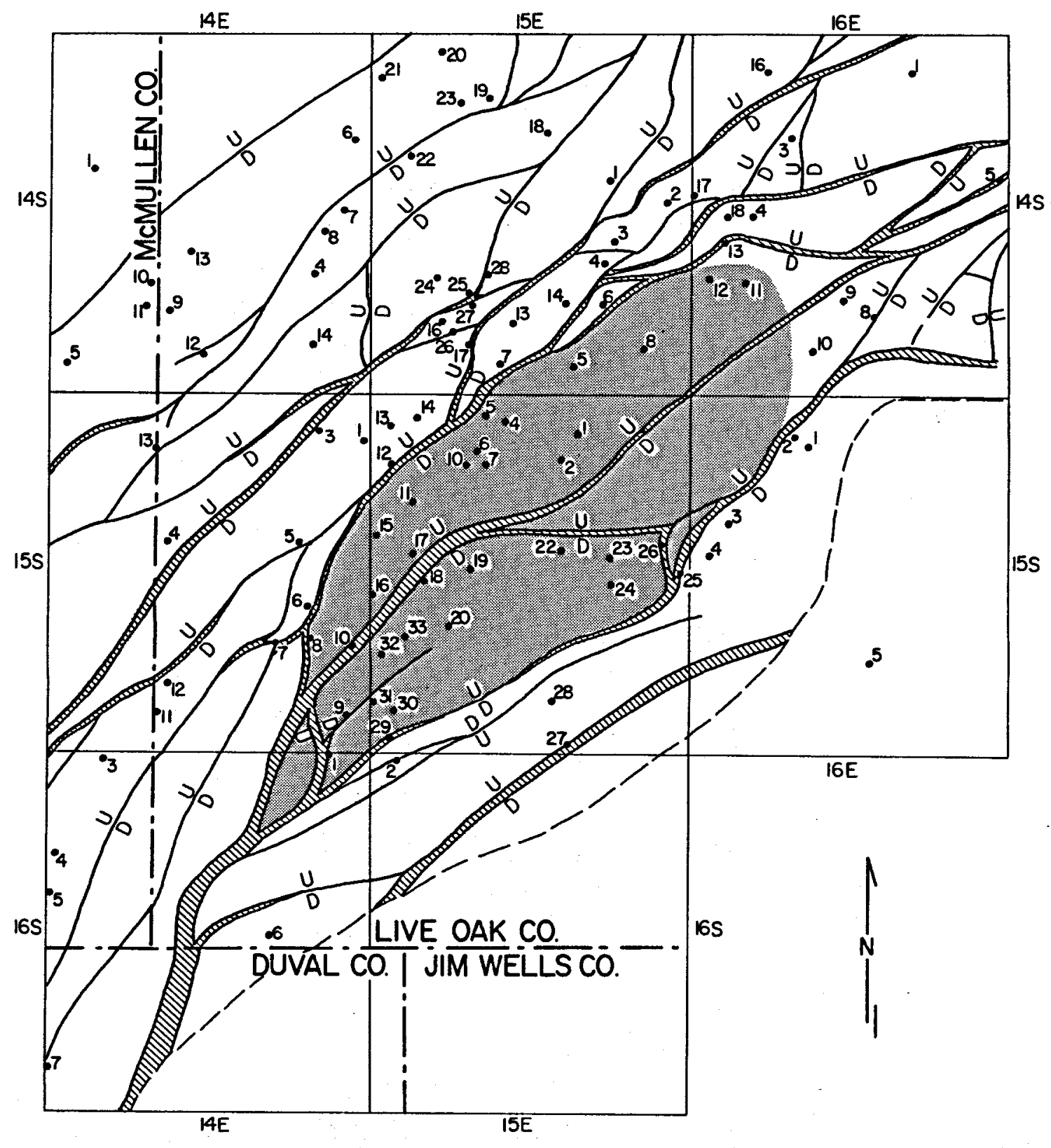

EXPLANATION

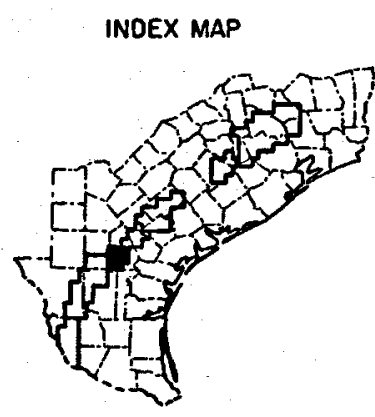

Areo of most prospective reservoirs

- Well control

- Limit of structural conlrol

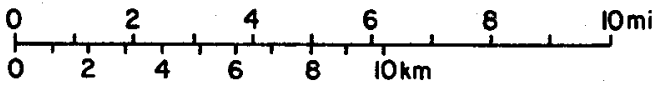

Figure 63. Well control, faults at the top of the Wilcox, and area of prospective sandstones, Live Oak Fairway. 


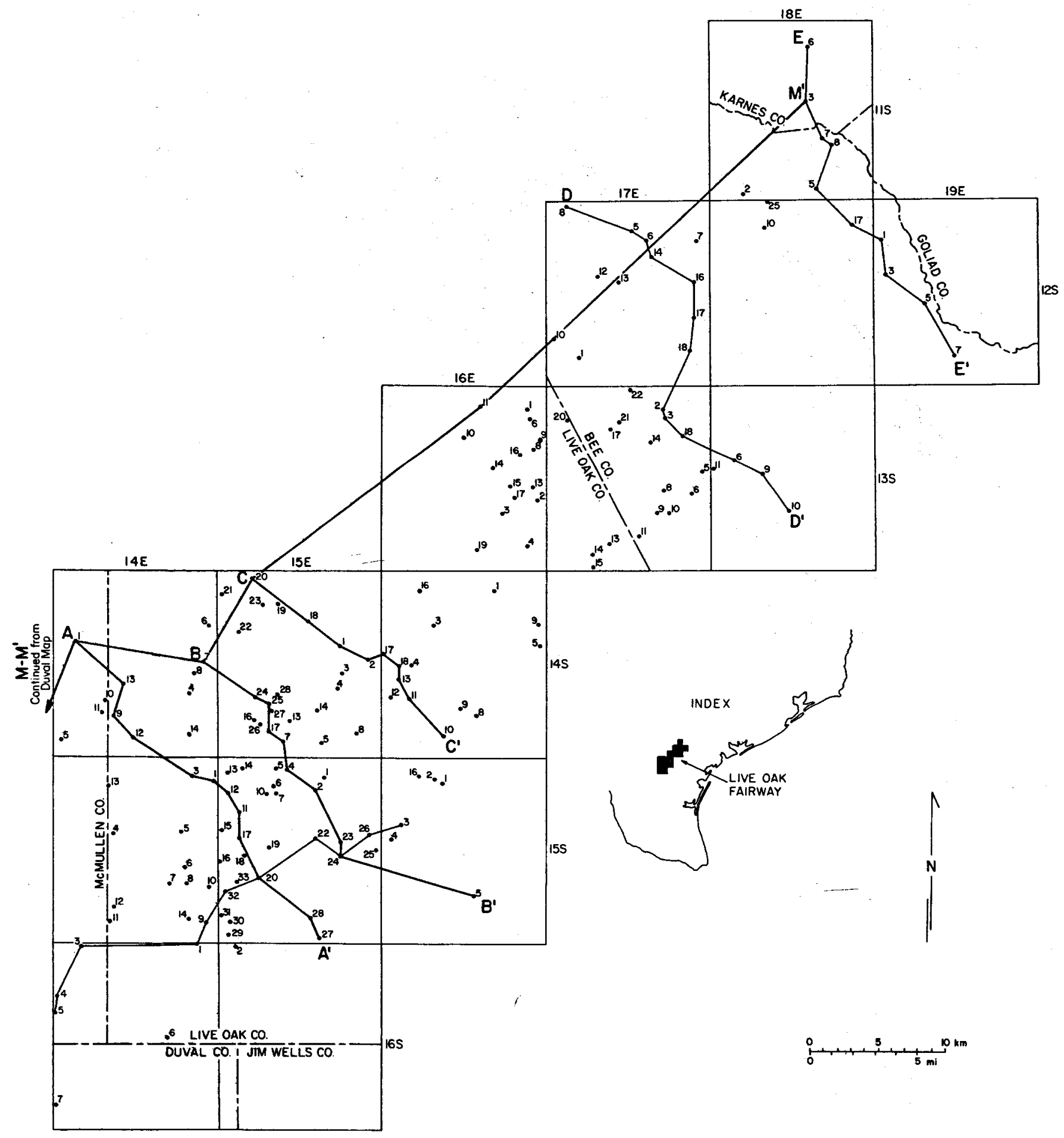

Figure 64. Well control and lines of stratigraphic and structural sections, Live Oak Fairway and area to the northeast. Heavy lines indicate the sections included in this report. 


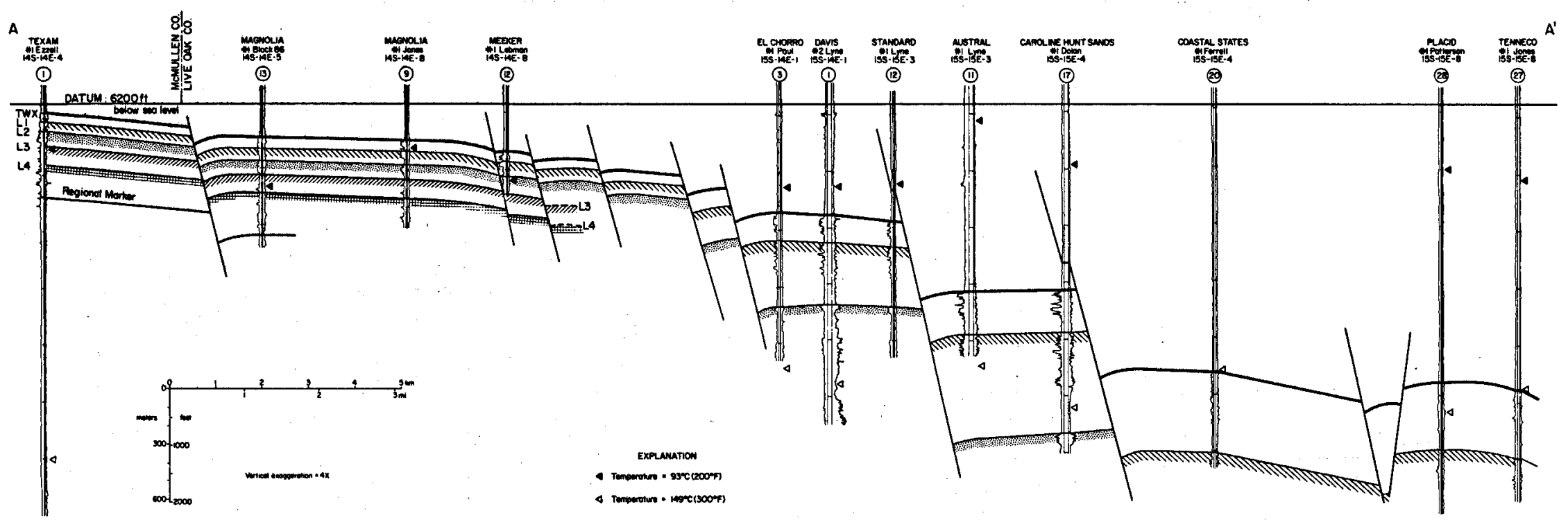

Figure 65. Structural dip section AA, southern part of the Live Oak Fairway. 


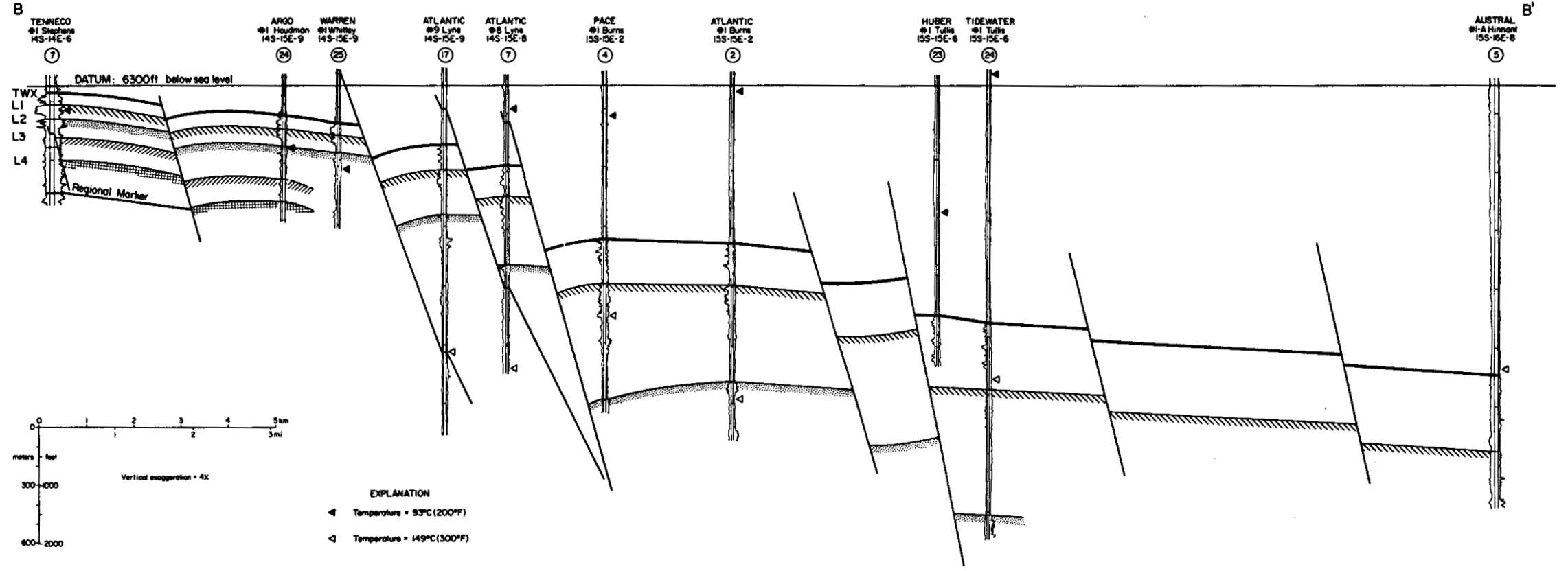

Figure 66. Structural dip section BB', central part of the Live Oak Fairway. 
C

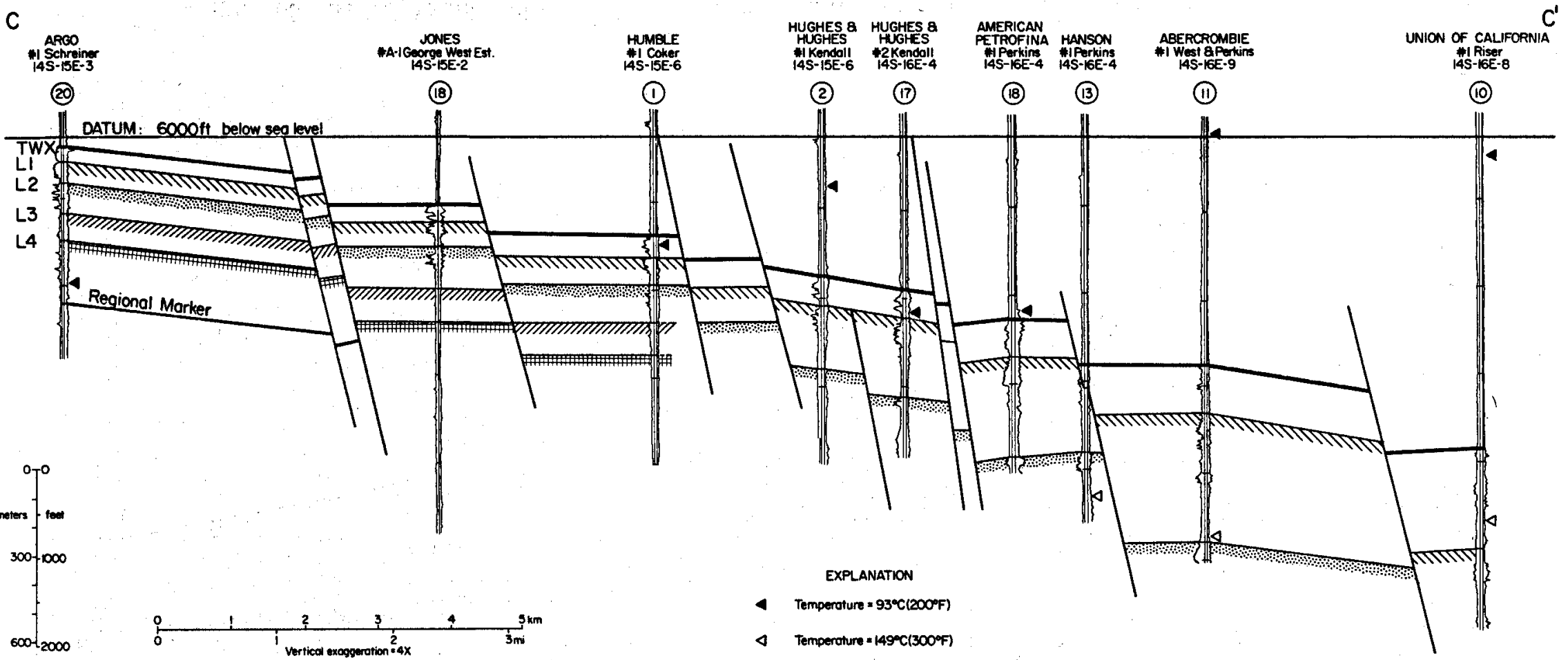

Figure 67. Structural dip section $C^{\prime}$, northern part of the Live Oak Fairway. 
A
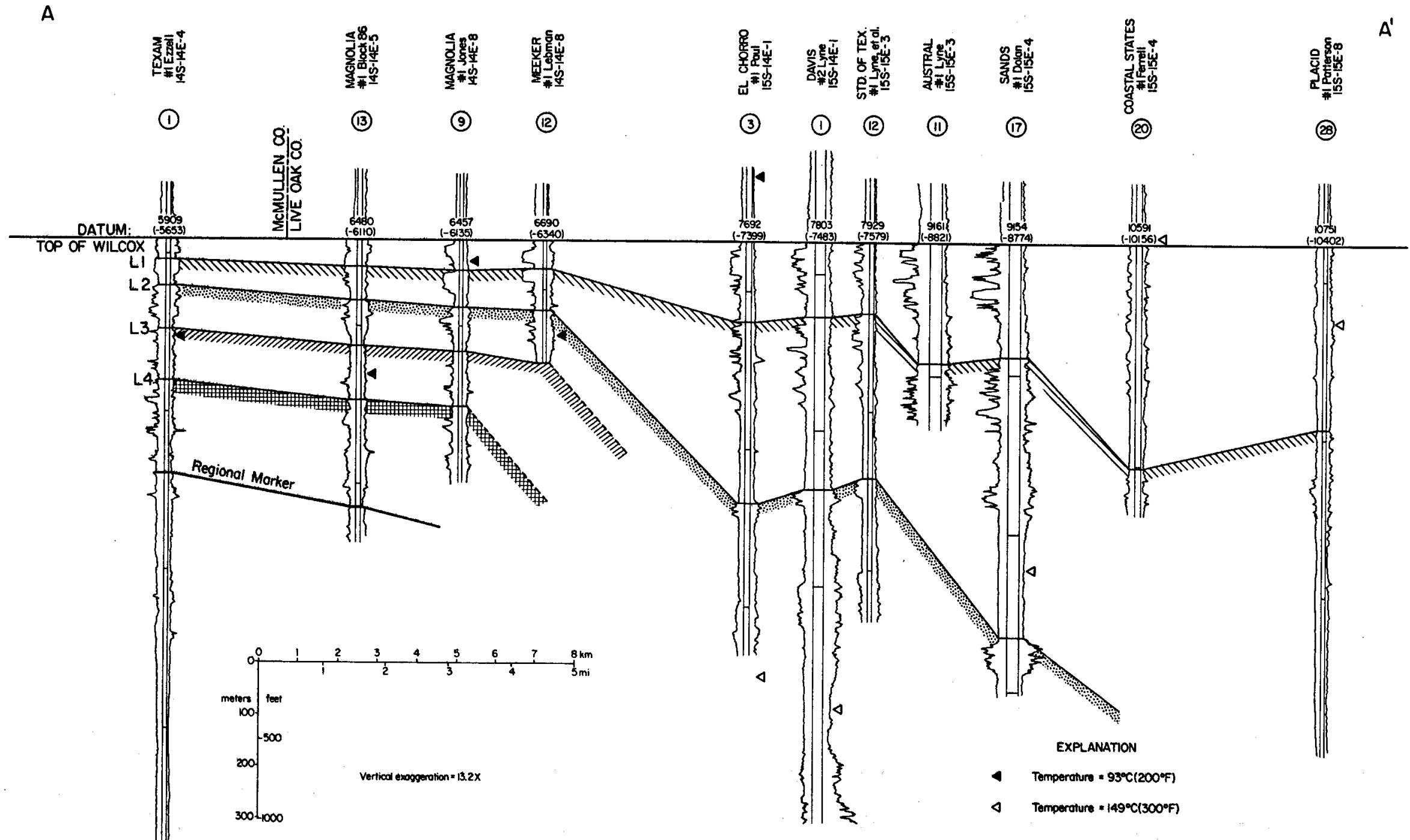

Figure 68. Stratigraphic dip section $A A^{\prime}$, southern part of the Live Oak Fairway. Growth faults are not shown in order to better show correlation between wells. 


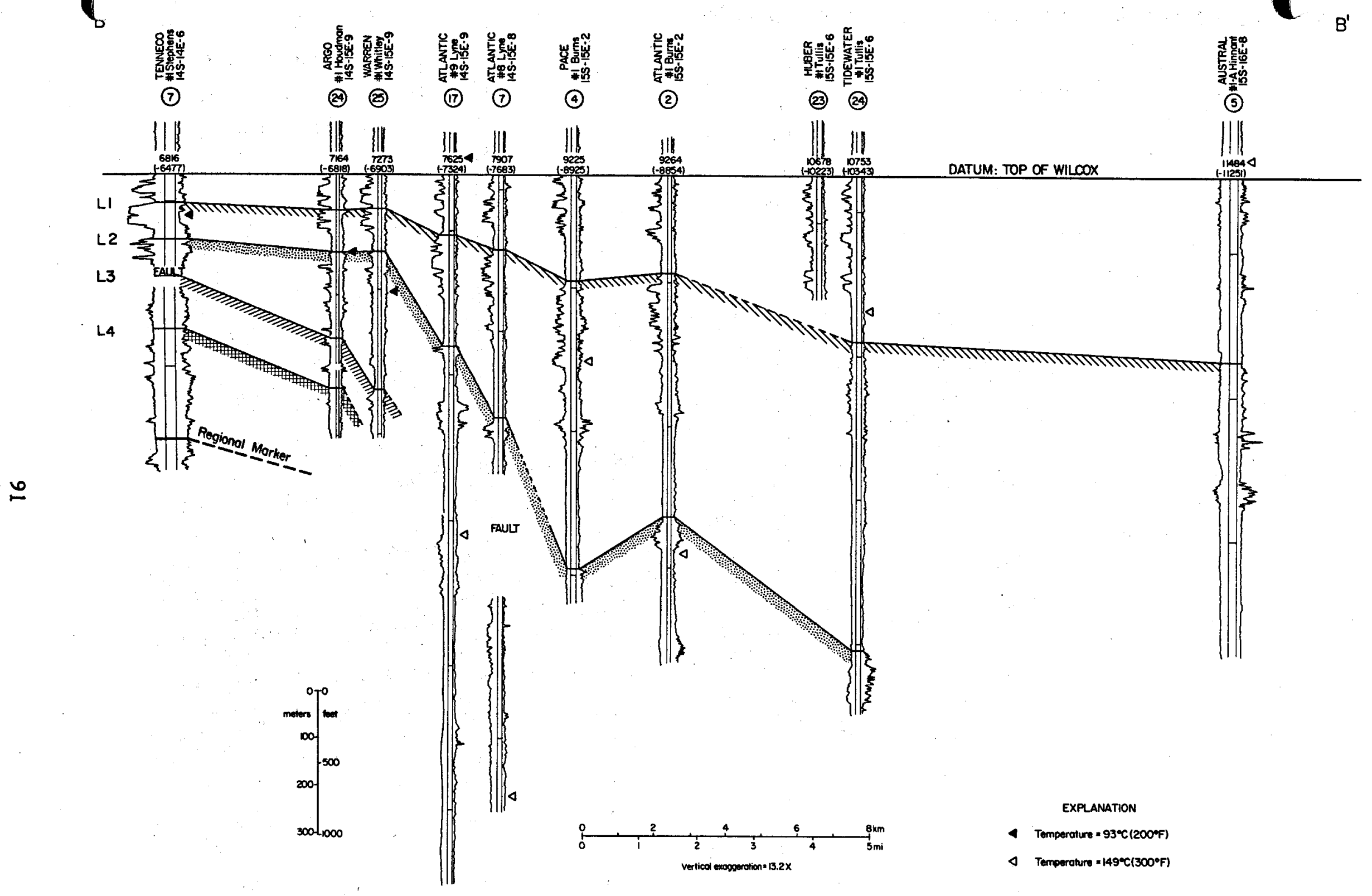

Figure 69. Stratigraphic dip section BB', central part of the Live Oak Fairway. 
C

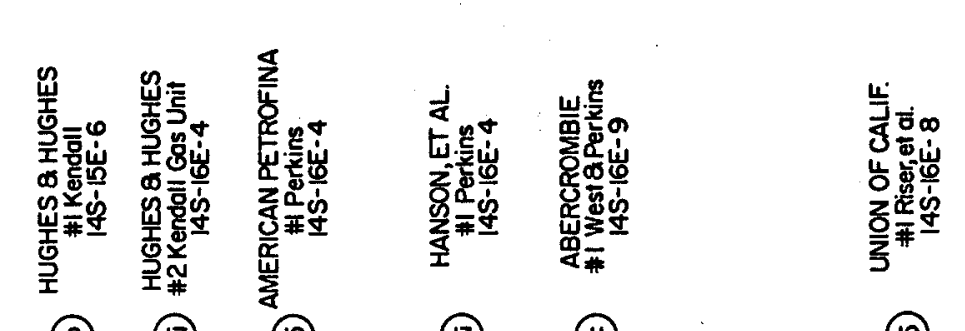

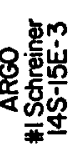

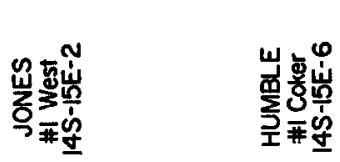

(2) (17)

(18)

(13)

(II)

(10)

(20)

(18)

(1)

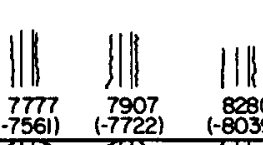

6.648 1 DATI3) DATU: TOP OF WILCOX

$\|_{\substack{7060 \\ 6732)}}$

III III 3.-7561) $\frac{7408}{877371}$

LI

L2

L3

L4
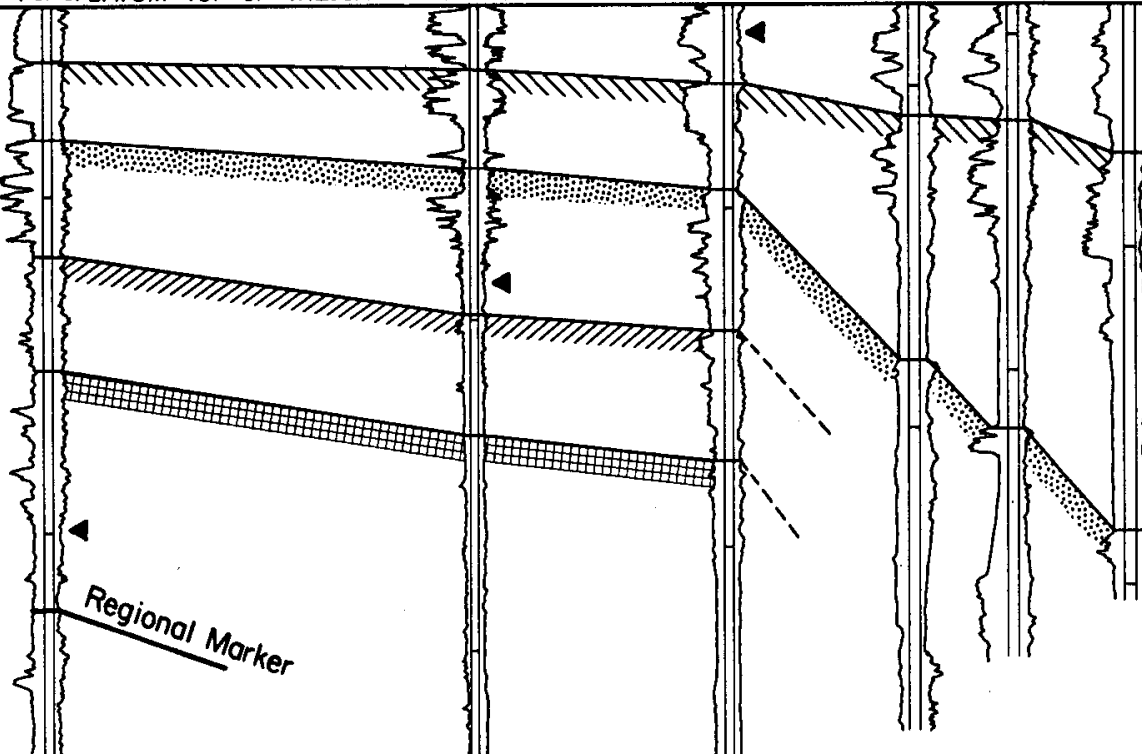

NIIIIIIIII

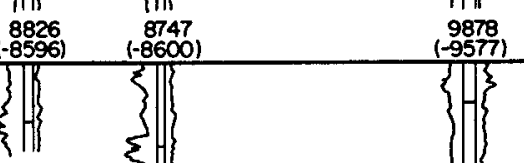

EXPLANATION

- Temperafure $=93^{\circ} \mathrm{C}\left(200^{\circ} \mathrm{F}\right)$

$\triangle$ Temperature $=149^{\circ} \mathrm{C}\left(300^{\circ} \mathrm{F}\right)$, 


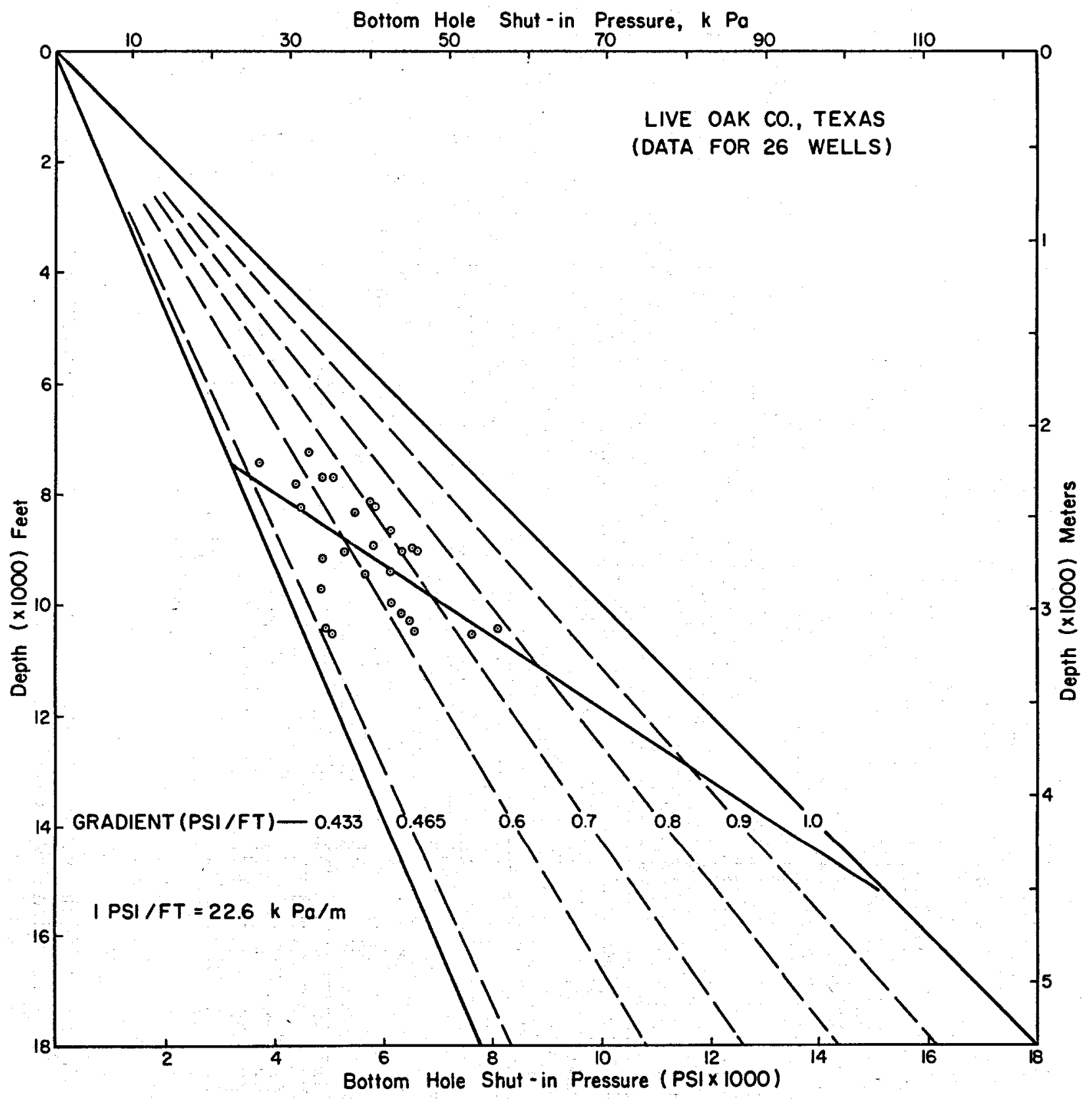

Figure 71. Bottom-hole shut-in pressures from drill-stem tests as a function of depth for 26 wells in Live Oak County. 


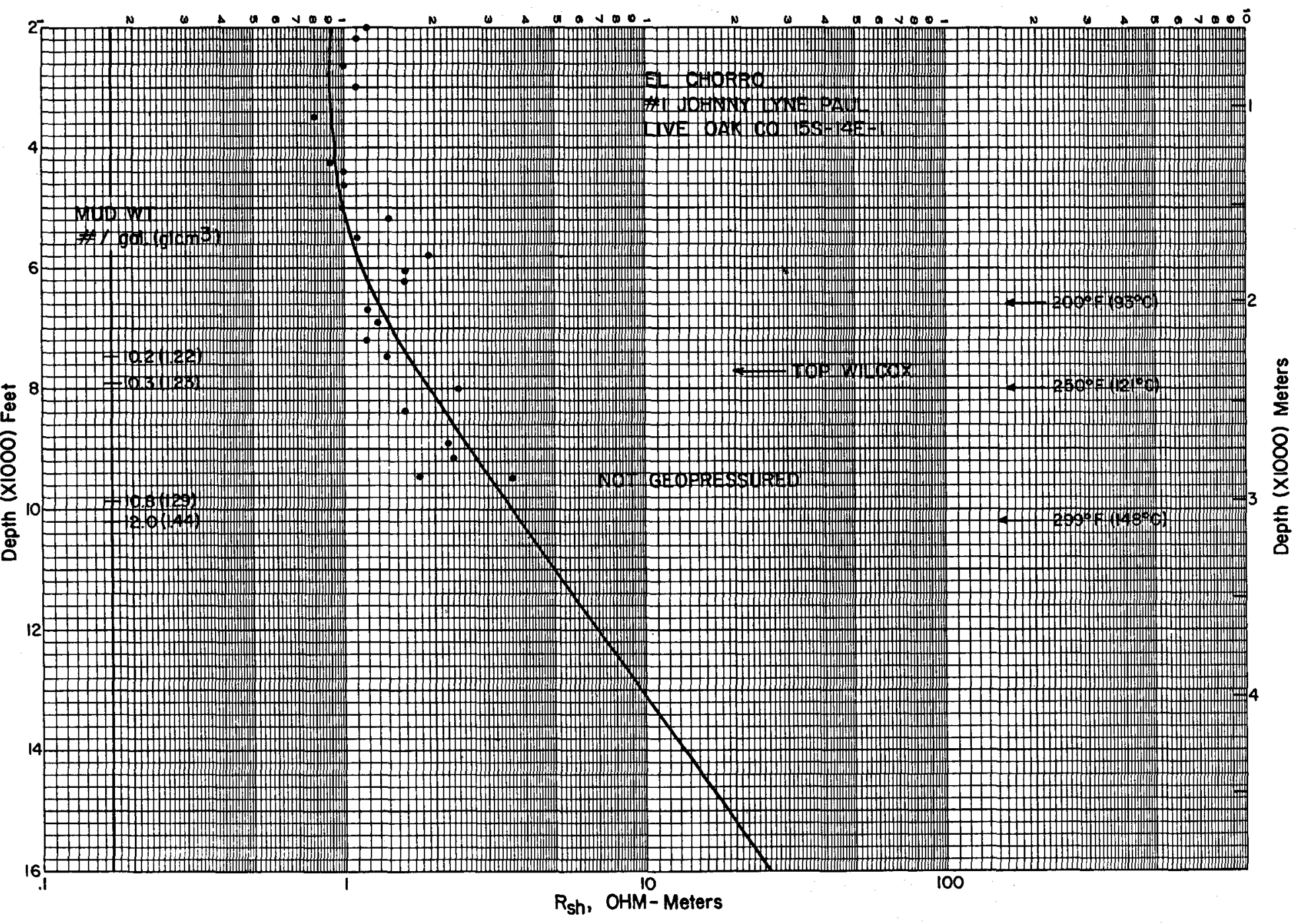

Figure 72. Shale resistivity-versus-depth plot for a non-geopressured well located updip on section $A A^{\prime}$, Live Oak County. 


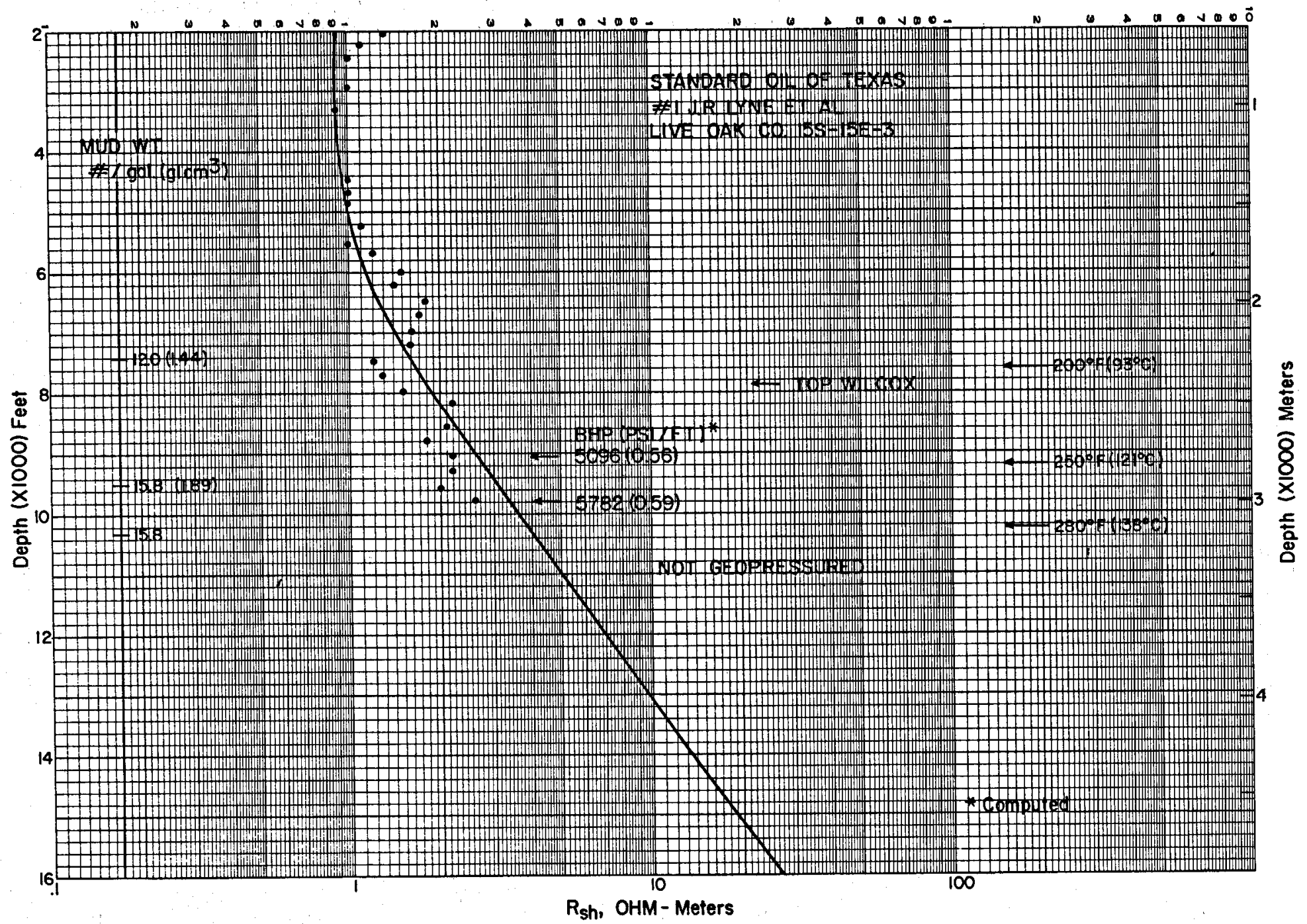

Figure 73. Shale resistivity-versus-depth plot for a non-geopressured well located on section AA', Live Oak County. 


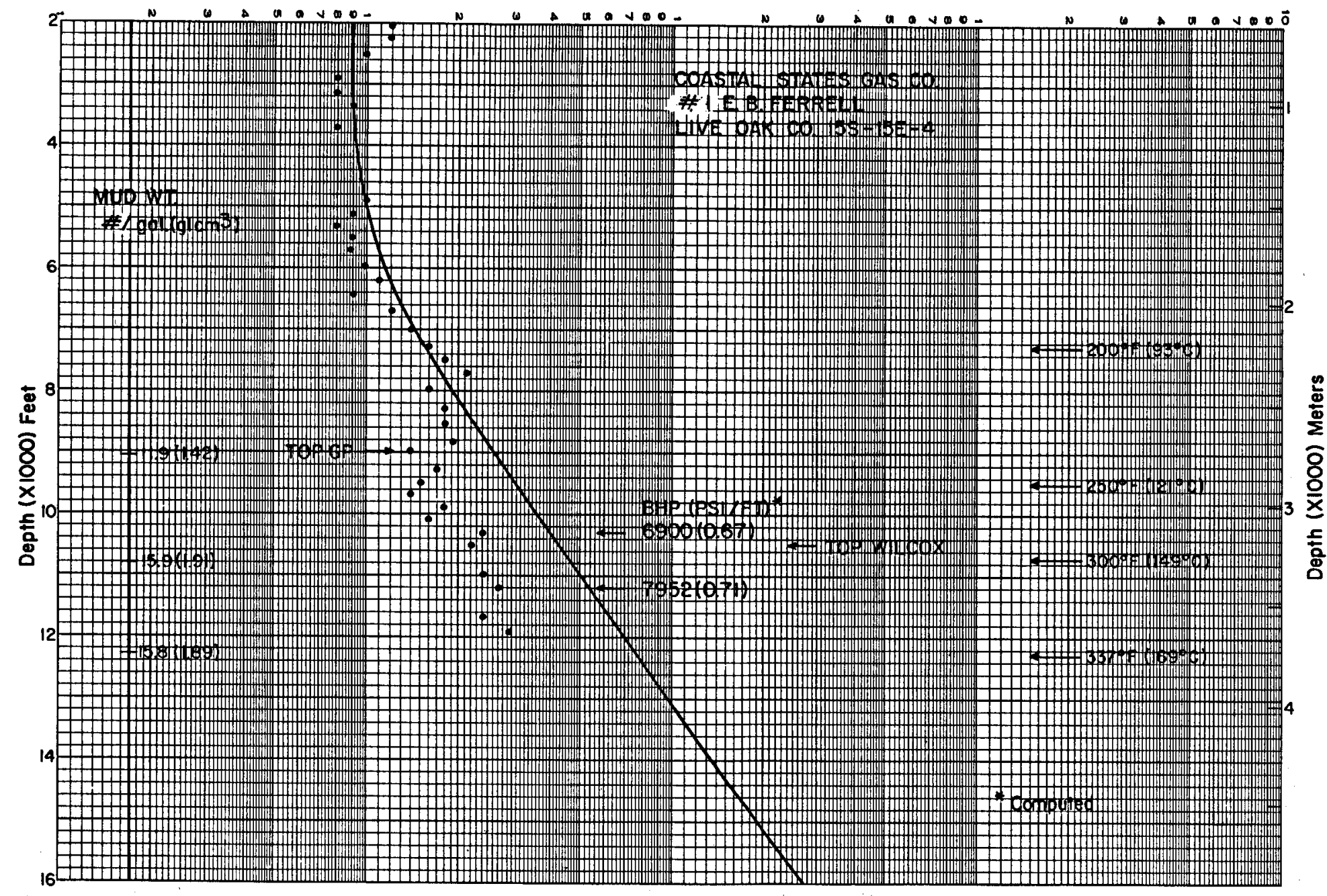

$\mathbf{R}_{\text {sh }}$, OHM-Meters

Figure 74. Top of geopressure and geopressure gradients from shale resistivity for a well on section AA', Live Oak County. 
A

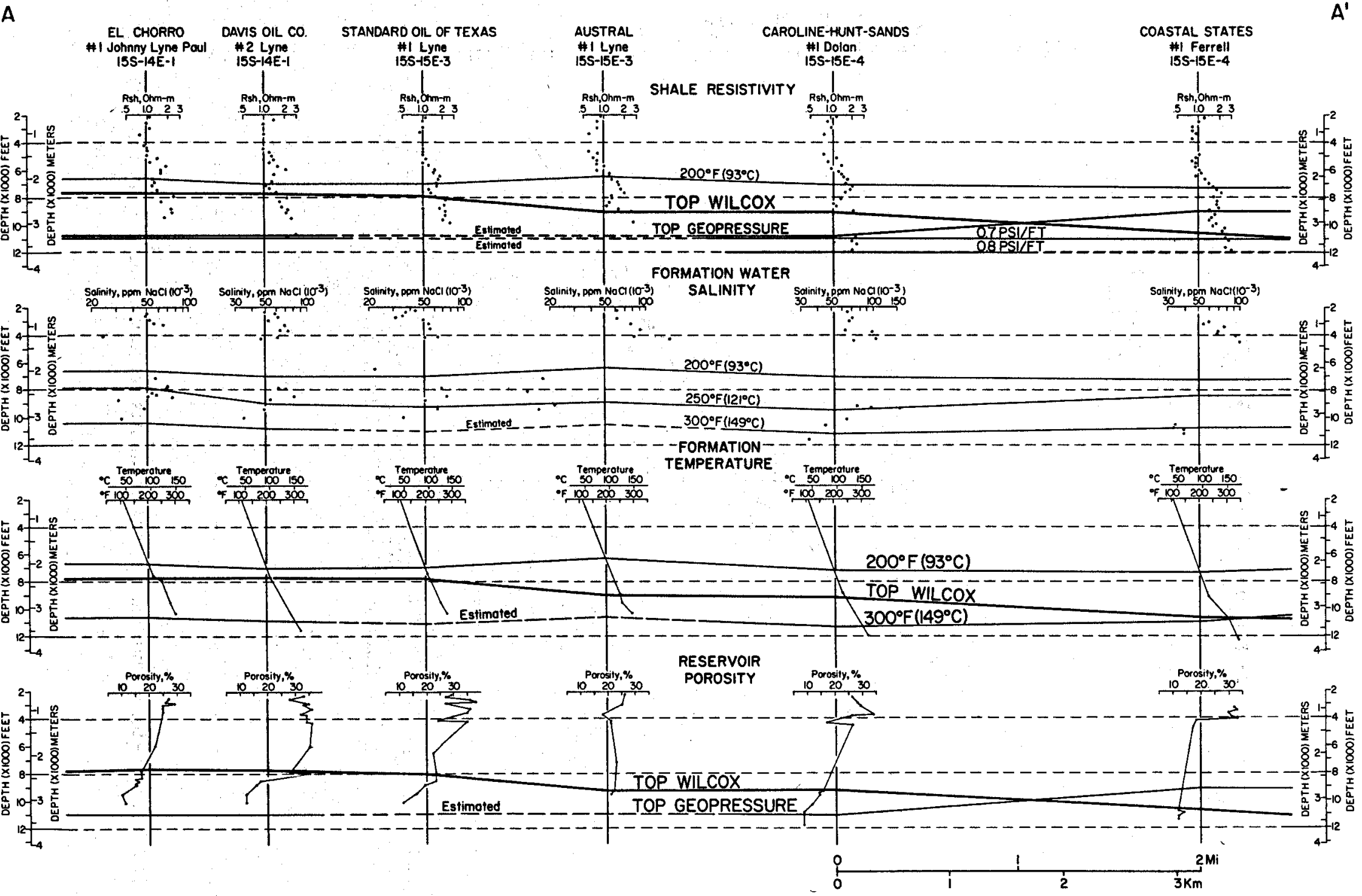

Figure 75. Parameter well profile plots showing variation of formation and fluid properties along section AA', Live Oak County. 


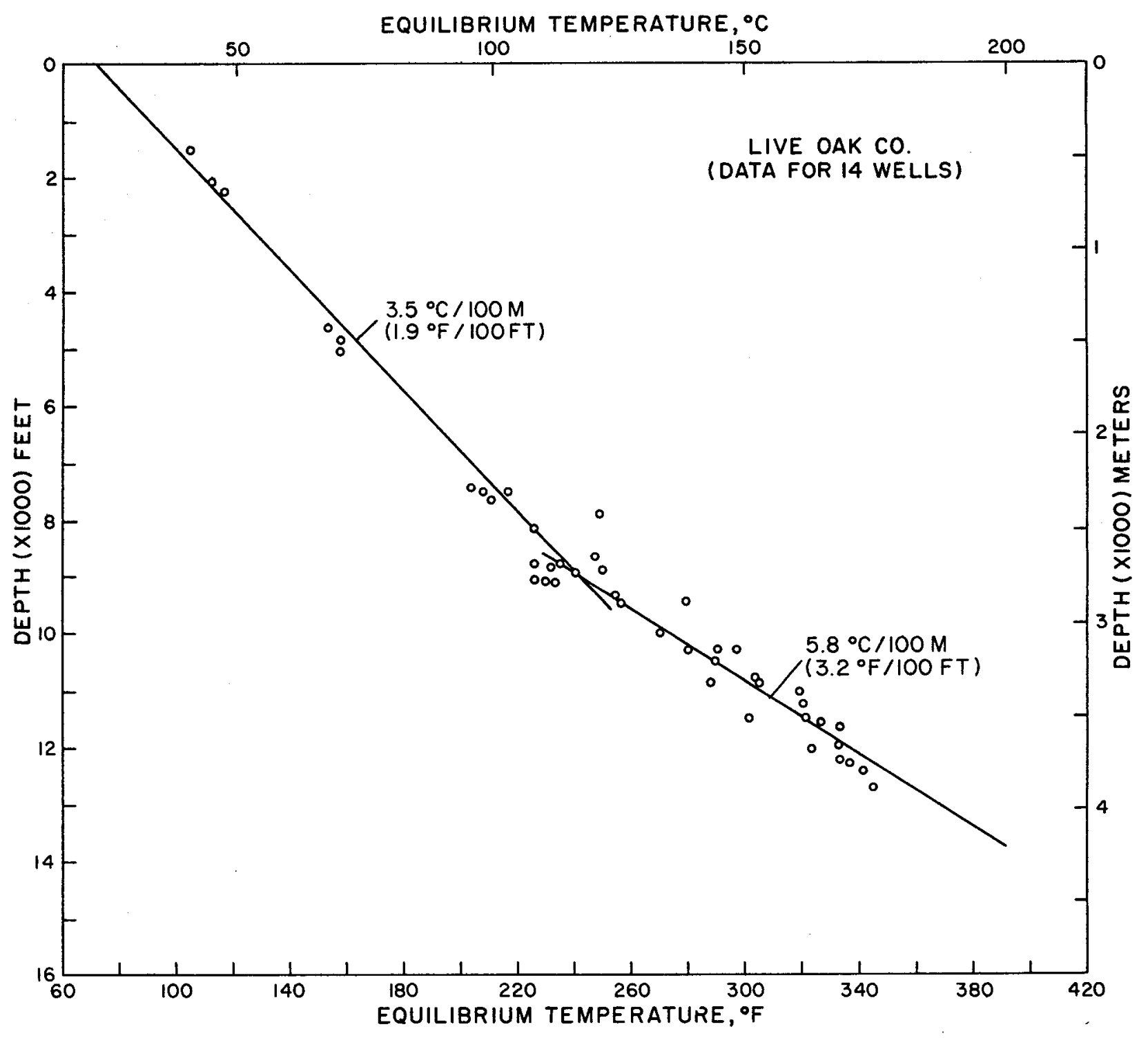

Figure 76. Temperatures and geothermal gradients for Live Oak County Fairway area. 


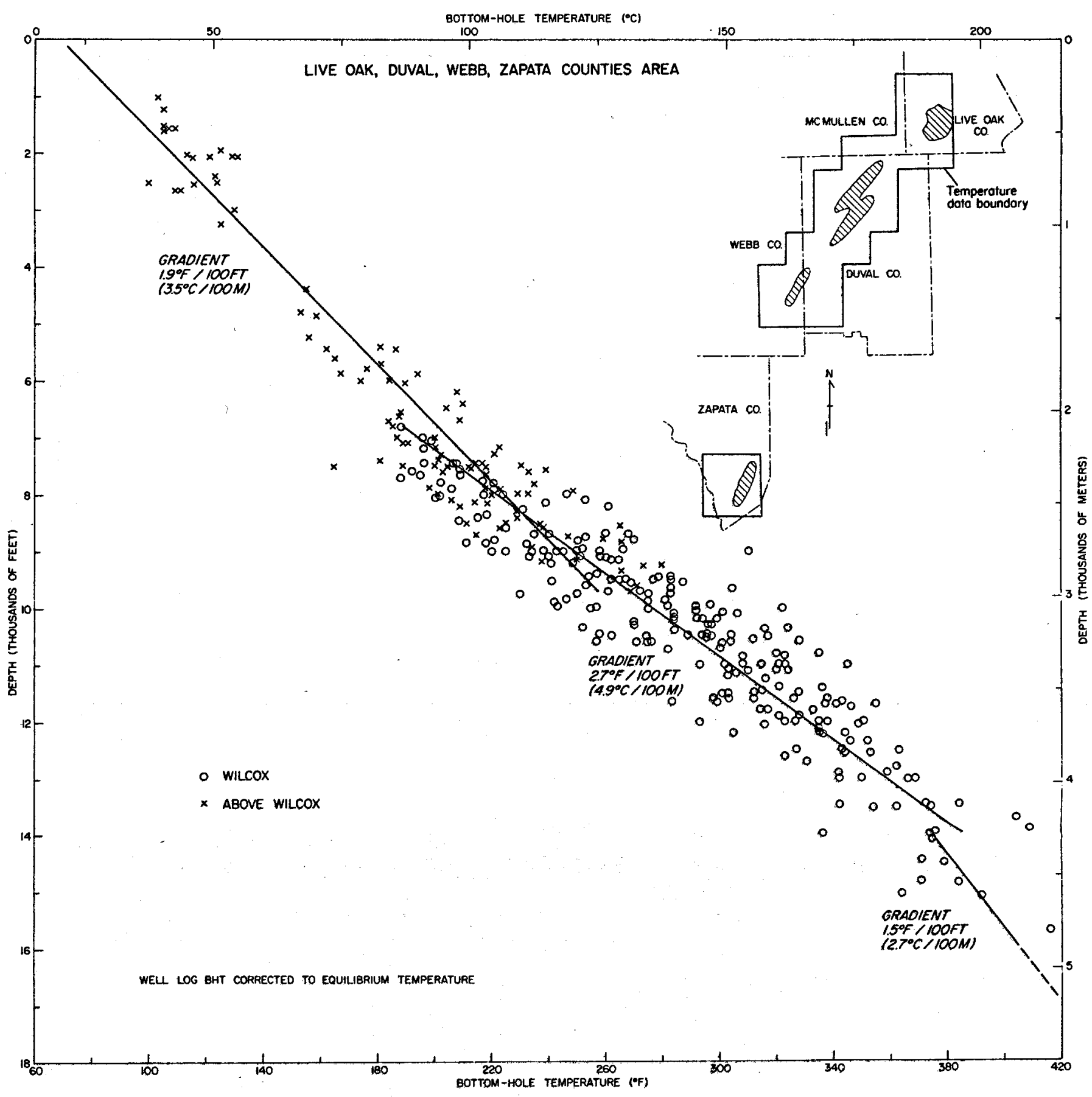

Figure 77. Temperatures and geothermal gradients for fairway area including parts of Live Oak, McMullen, Duval, Webb, and Zapata Counties. 


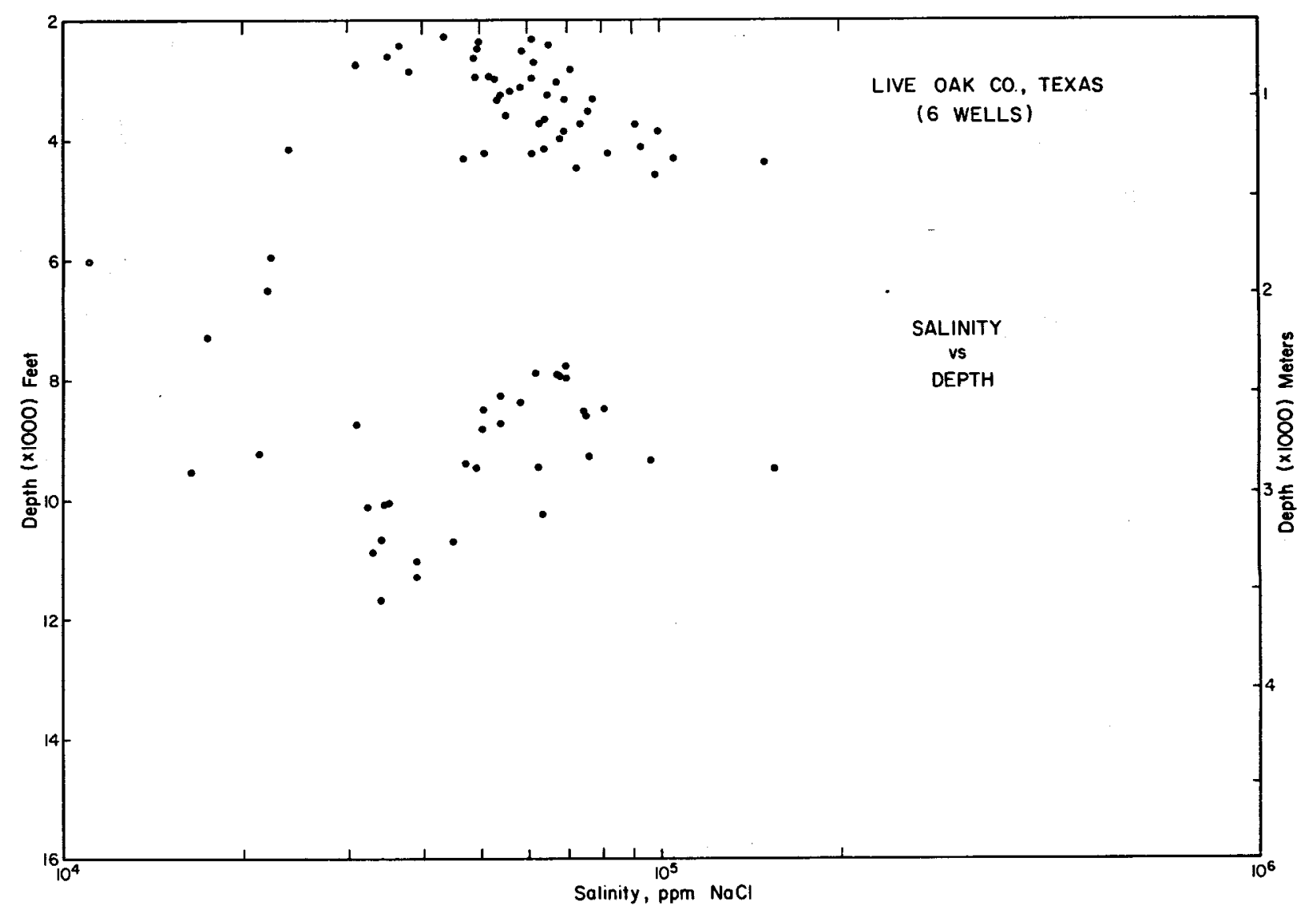

Figure 78. Salinity versus depth for six wells in Live Oak County. 


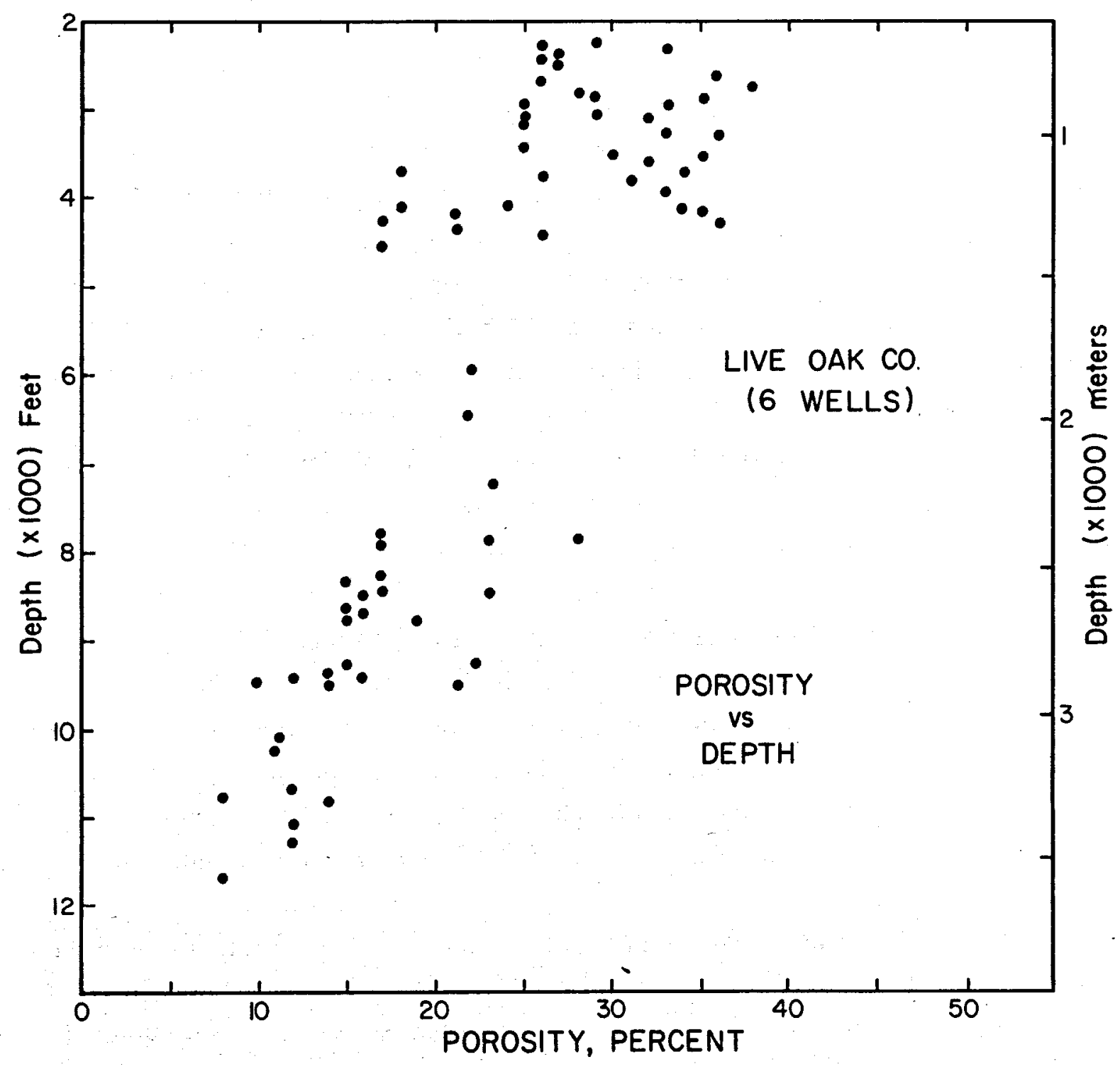

Figure 79. A plot of porosity versus depth for six wells in Live Oak County. 


\section{DE WITT FAIRWAY - DEPOSITIONAL AND STRUCTURAL STYLE}

The prospective geopressured geothermal reservoirs in the De Witt Fairway occur in the lower Wilcox in the complexly growth-faulted portion of the trend just downdip of the Lower Cretaceous Stuart City Trend.

The De Witt Fairway, located in southeastern De Witt County (fig. 80), is $64 \mathrm{~km}$ $(40 \mathrm{mi})$ long northeast-southwest and $10 \mathrm{~km}(6 \mathrm{mi})$ wide and was first recognized with widely spaced well control on the regional cross sections. Detailed study of the De Witt Fairway is based on analysis of electrical logs from all wells which penetrate the lower Wilcox (fig. 80). Five stratigraphic dip sections and one stratigraphic strike section established the correlation grid into which all well logs were correlated; only

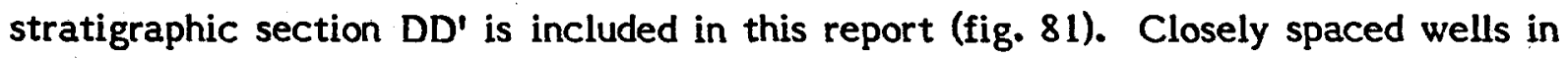
the fairway can be correlated with confidence with electrical logs primarily by means of resistivity markers within the shale and siltstone sections. Several of these markers have been carried across the entire fairway area and are the basis for subdividing the formation into five units in the De Witt Fairway. Two of these markers (DL and D2) are considered regional markers and have been carried throughout the Wilcox trend in Texas as indicated on the regional cross sections (figs. 10 through 32). The others are local to this fairway and do not correspond to markers used in the other fairways in this report. These markers do, however, provide a basis for subdividing the formation into thinner map units, which are more useful in delineating sandstone and shale trends and interpreting general depositional environments. Potential geopressured geothermal sandstone reservoirs occur beneath the D4 marker where temperatures are greater than $149^{\circ} \mathrm{C}\left(300^{\circ} \mathrm{F}\right)$.

The Wilcox Group in the De Witt Fairway is readily divisible vertically into three main parts: the lower part beneath the $\mathrm{D} 4$ marker, the middle part between the D4 and Dl markers, and the upper part from the D1 marker to the top of the Wilcox (fig. 81). The lower part is characterized by high sandstone content which is highly variable laterally as a result of rapid facies changes. The middle part consists dominantly of shale and thin sandstone units that are dominantly strike aligned (fig. 82), and persistent over a large area, and provide excellent correlation markers. The upper part is mainly massive sandstone, which, when mapped, shows a dominant dip-oriented component (fig. 83); detailed correlations are possible only in the thin sandstones and shale of the lower part. 
The depositional/structural style of the Gulf Coast Basin is controlled by growth faults which form contemporaneously with deposition. The De Witt Fairway is located in the complexly growth-faulted portion of the Wilcox trend (figs. 6 and 82) just downdip of the Lower Cretaceous Stuart City carbonate shelf edge. The faults trend northwest parallel to the carbonate shelf edge and to the strike of the Wilcox. Displacement across the faults ranges from tens of feet to several hundred feet (figs. 83 to 89), but, in general, fault displacement and section thickening is greatest in the lower part of the Wilcox deeper than the D3 marker.

Local thickening of the sandstone and shale section updip into the bounding growth fault is a characteristic feature of growth faults but is not commonly documented because of a lack of well control close to the faults. In the De Witt Fairway, thickening is particularly well documented on line EE' (fig. 89) where the section thickens between markers D1 and D3 updip from well 15 to well 11. Regional thickening of the sections on the downdip side of growth faults is common and is illustrated on all of the dip cross sections (figs. 85 through 91). 


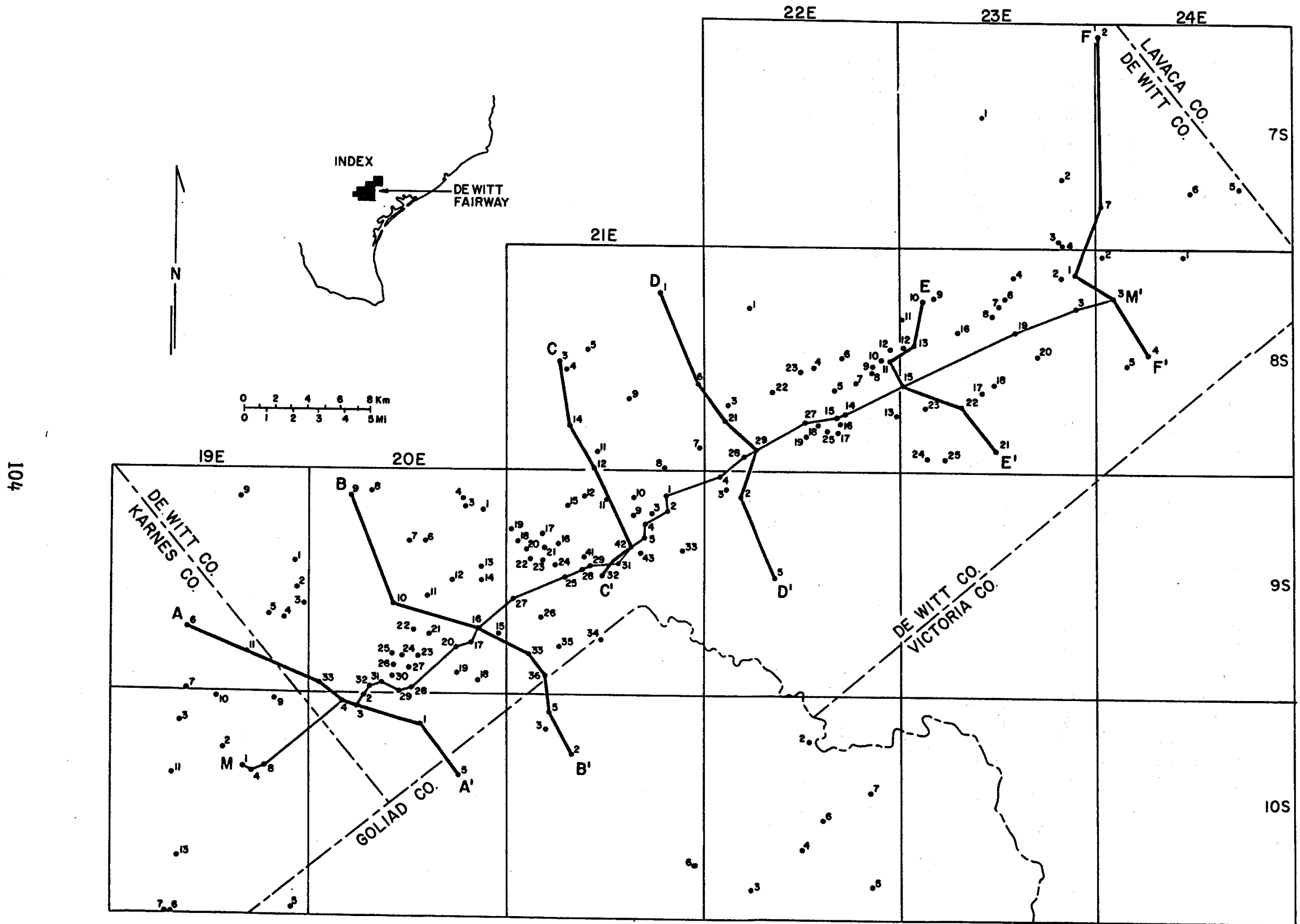

Figure 80. Location of wells and lines of section, De Witt Fairway. 
D

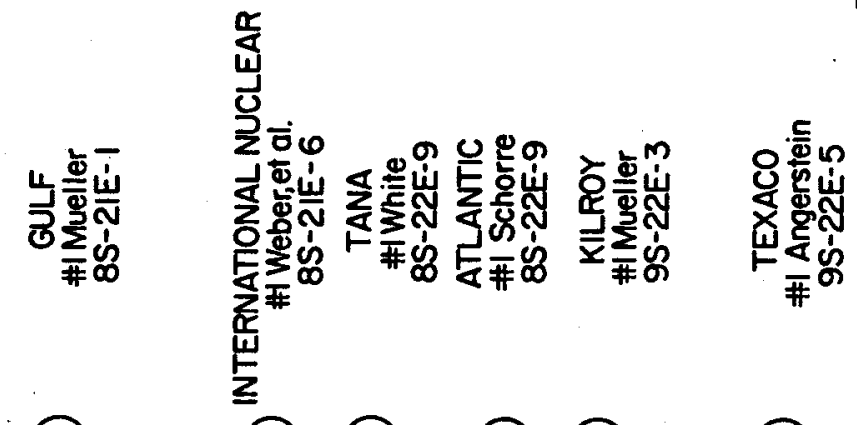
(1)
(6) (21) (29) (2)
(5)
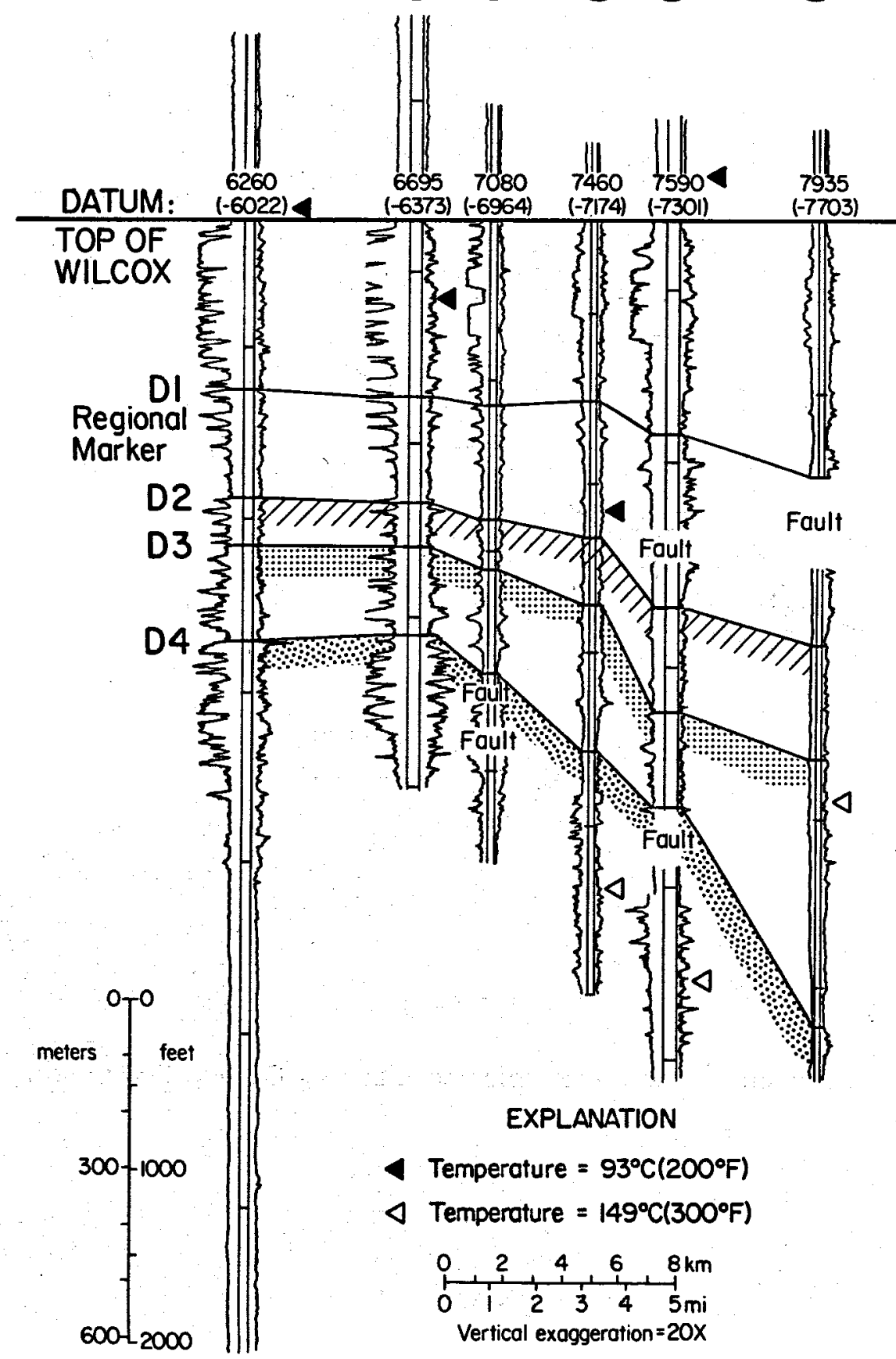

Figure 81. Stratigraphic dip section DD', De Witt Fairway. 


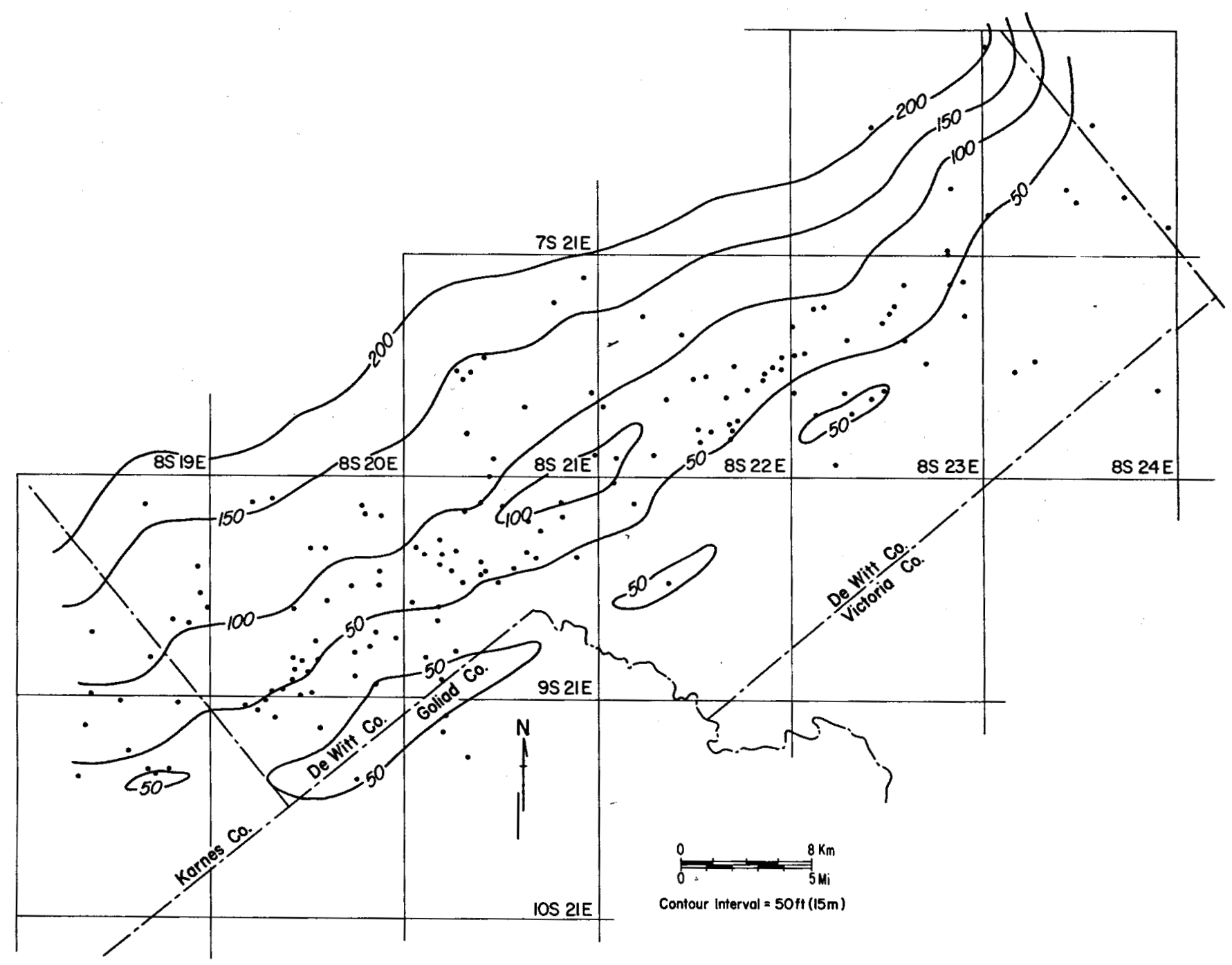

Figure 82. Net sandstone between correlation markers D2 and D3, middle Wilcox, De Witt Fairway. 


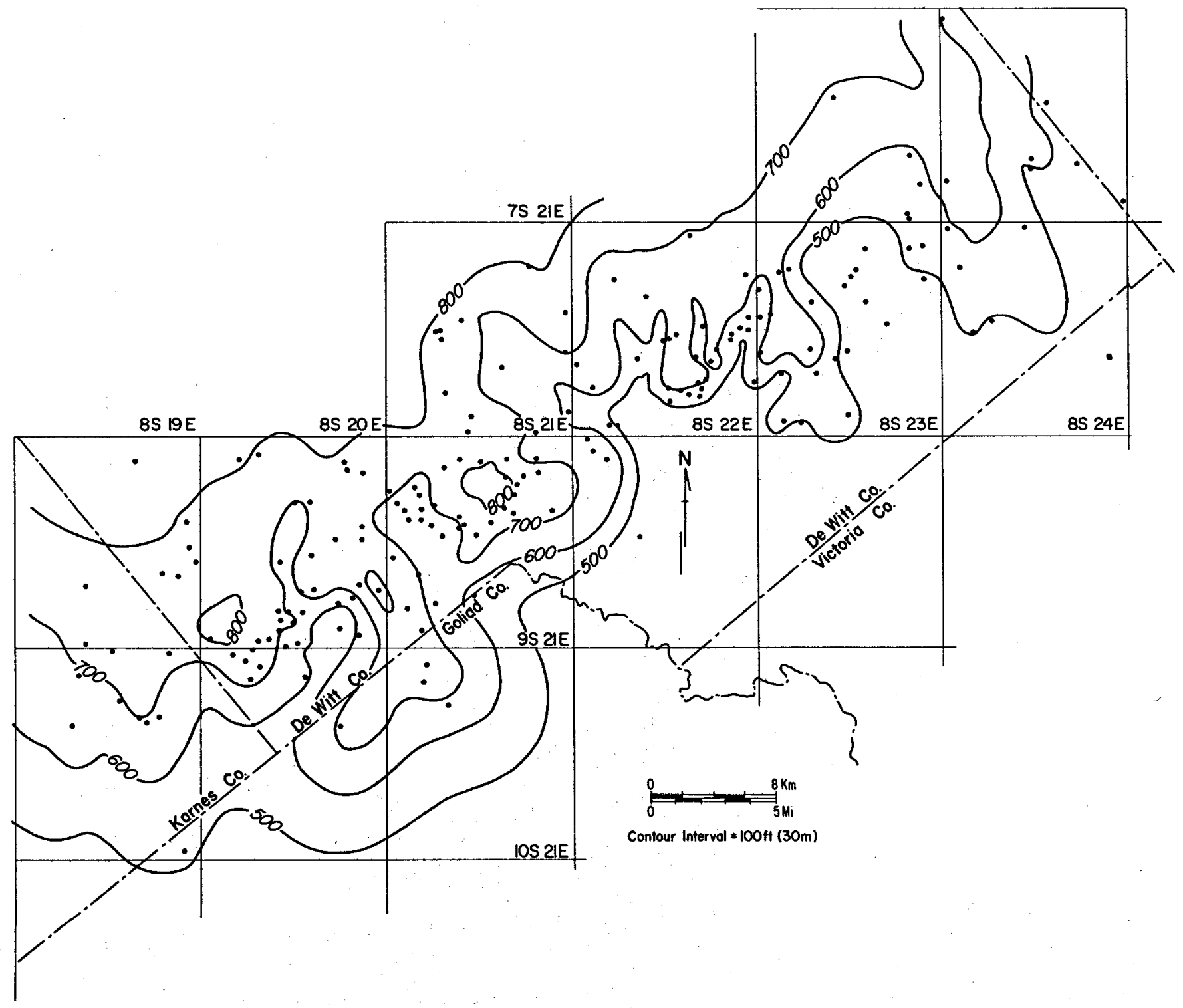

Figure 83. Net sandstone between the top of the Wilcox and the D1 marker, De Witt Fairway. 


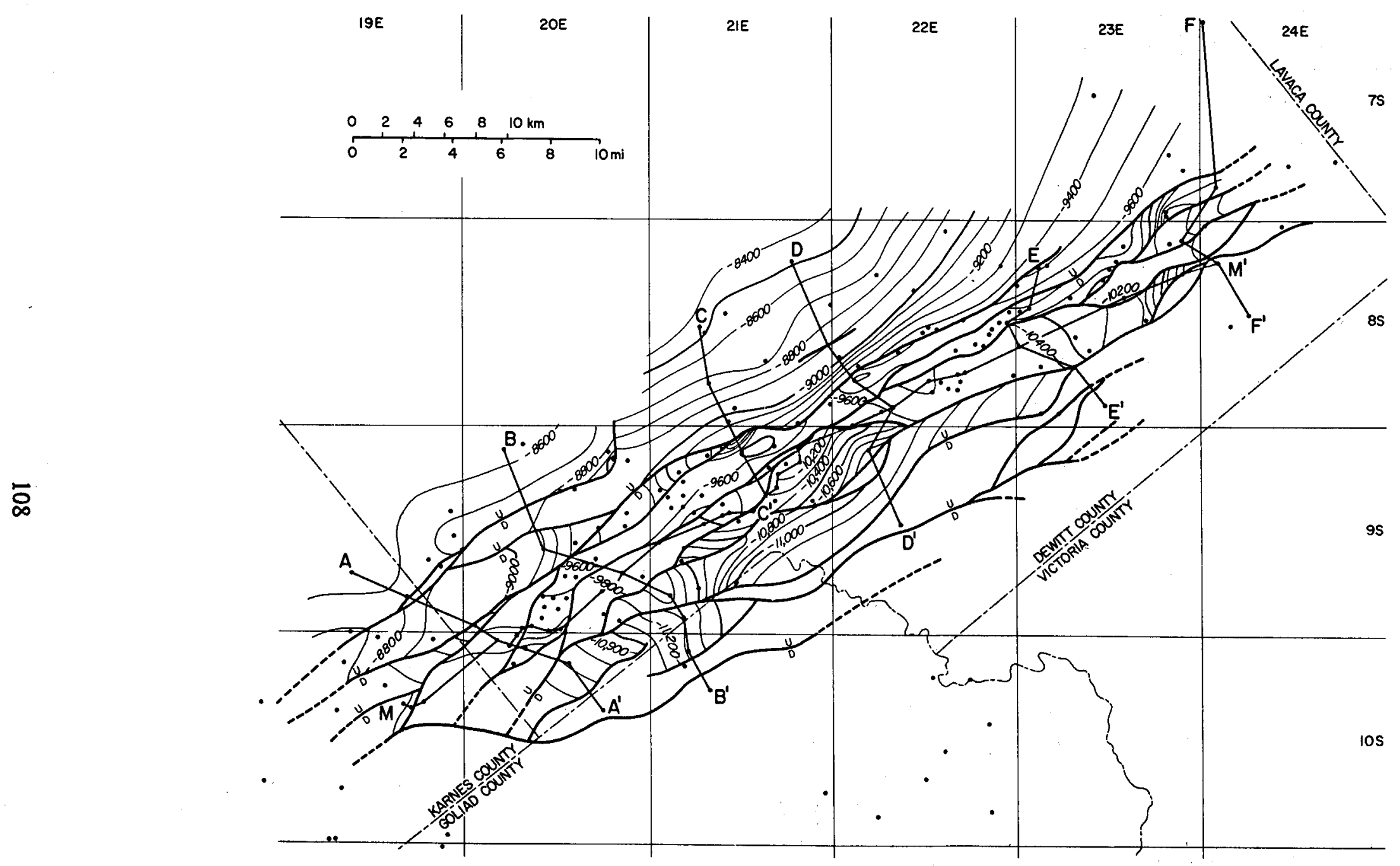

Figure 84a. Structure on top of the D4 marker, De Witt Fairway. 


\section{D}

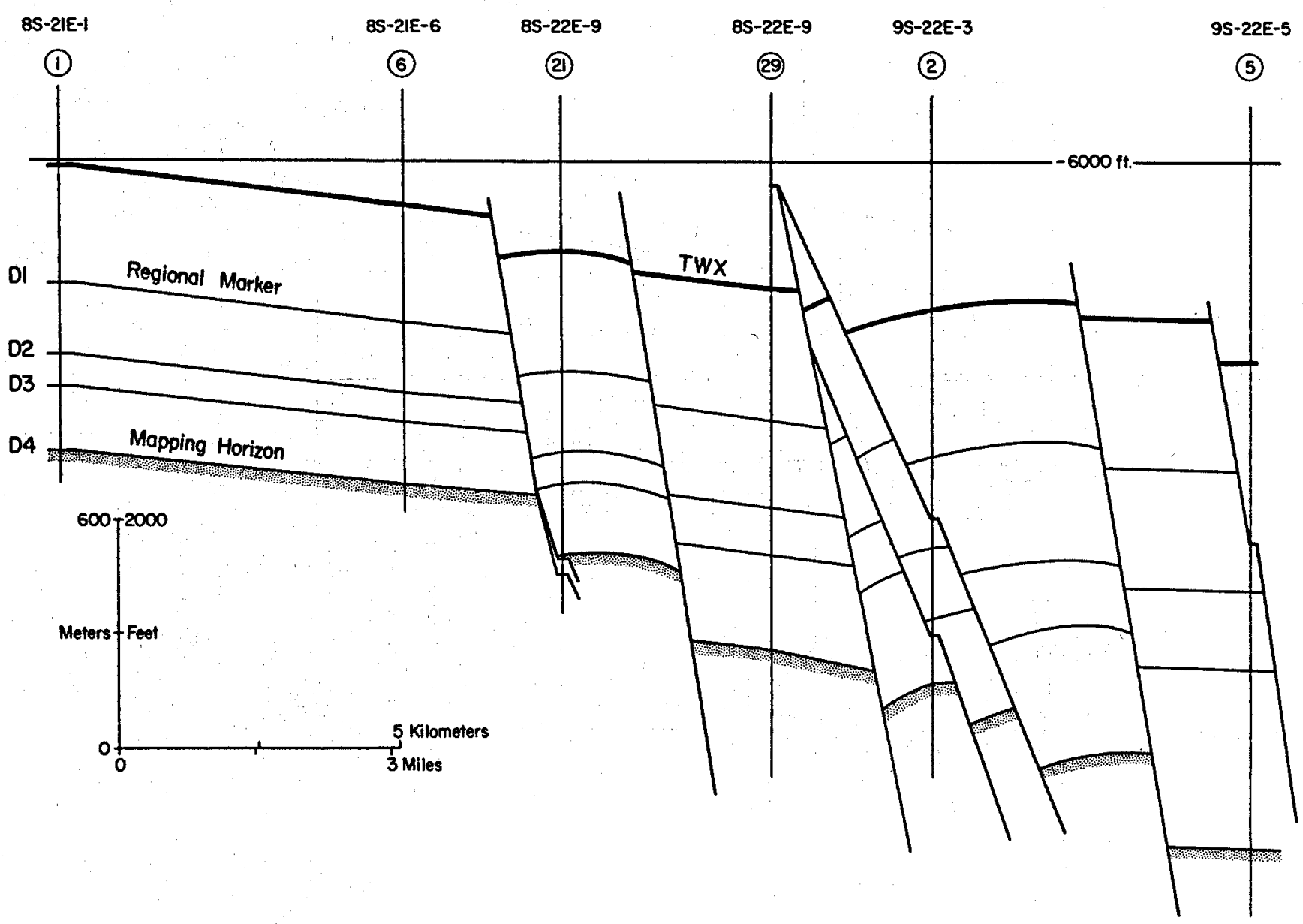

Figure 84b. Index cross section showing mapping horizon in figure $84 \mathrm{a}$. 


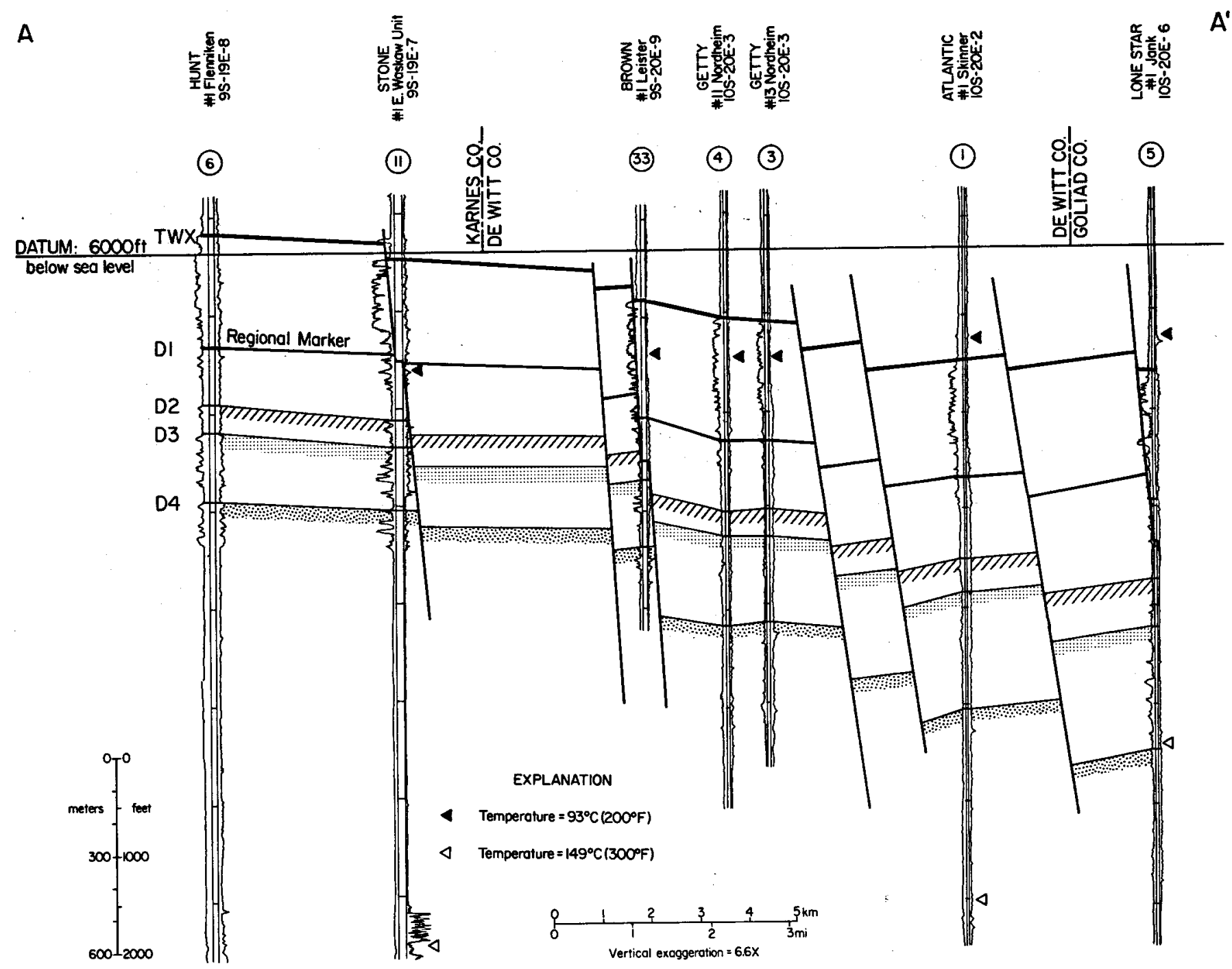

Figure 85. Structural dip section AA', De Witt Fairway. 


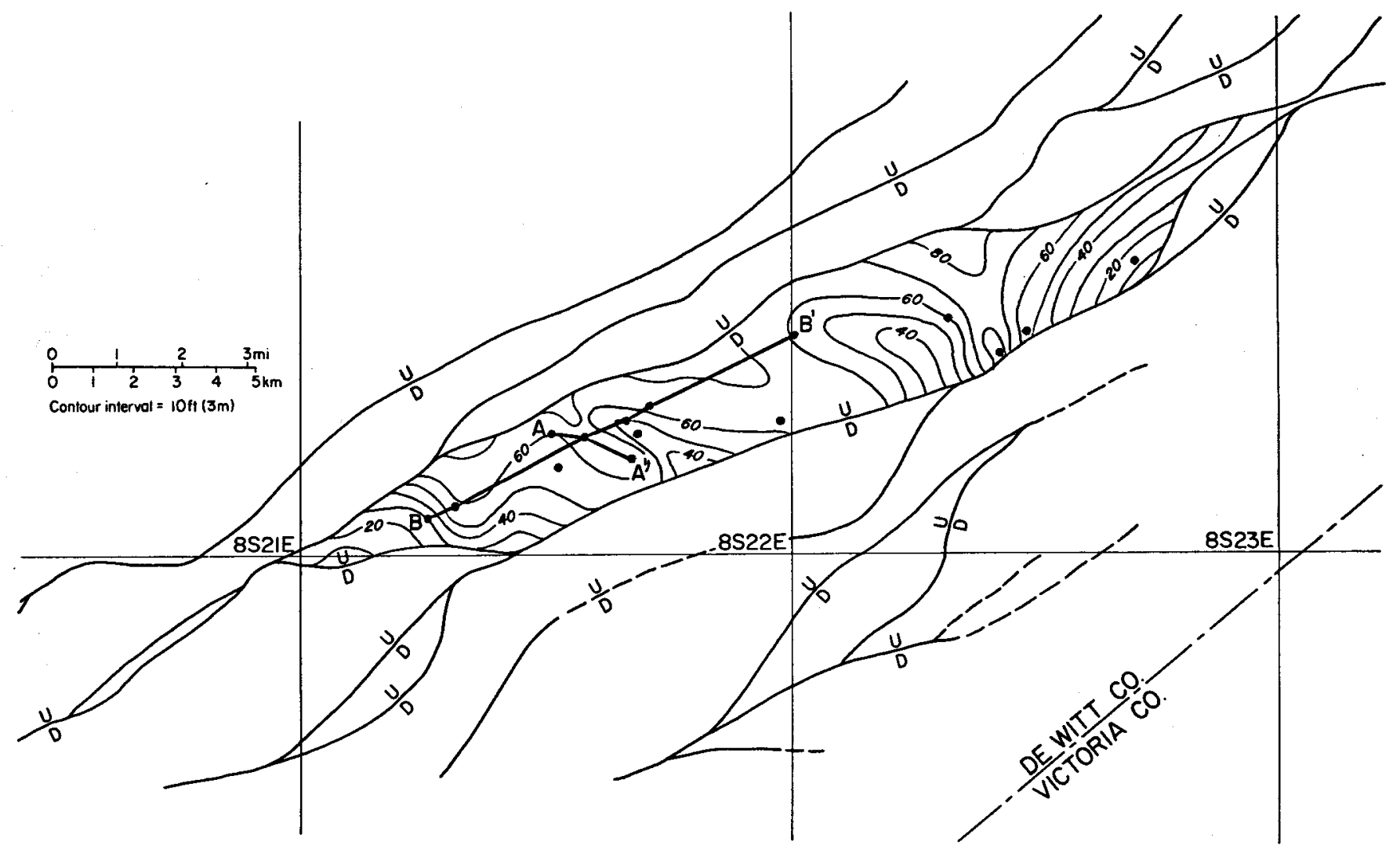

Figure 114. Net sandstone in correlation unit B, Cuero Prospect. 


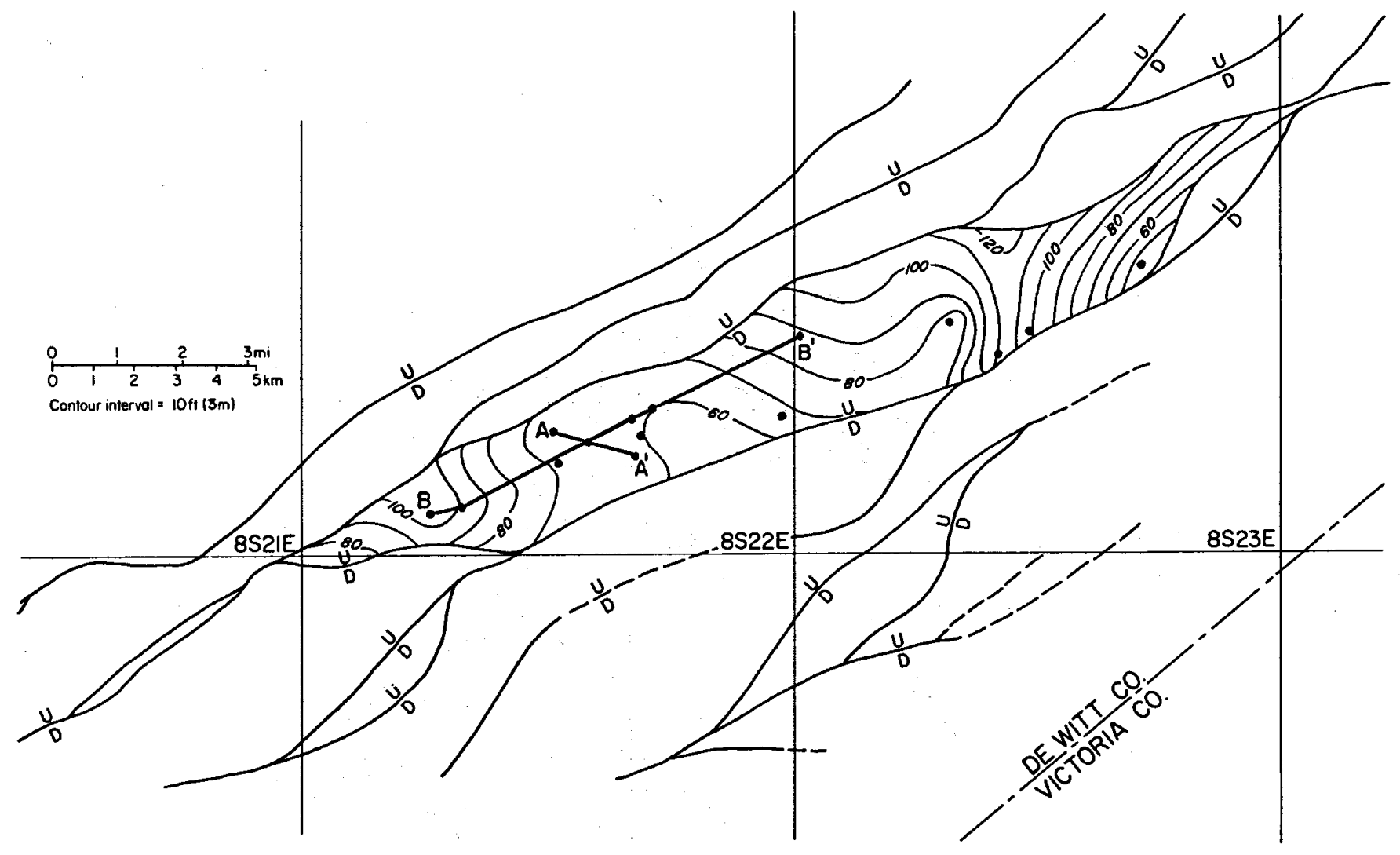

Figure 115. Net sandstone in correlation unit C, Cuero Prospect. 


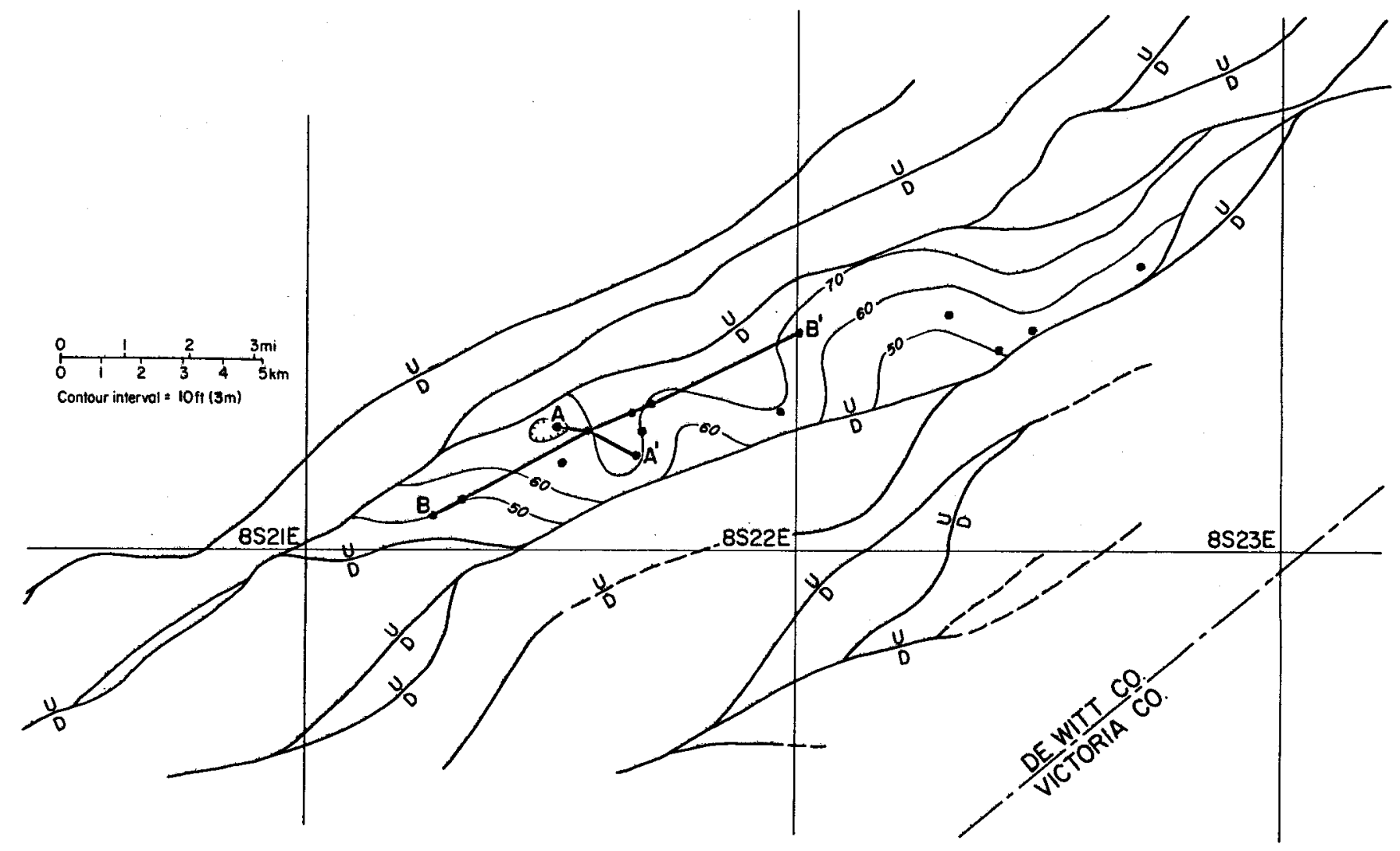

Figure 116. Net sandstone in correlation unit D, Cuero Prospect. 


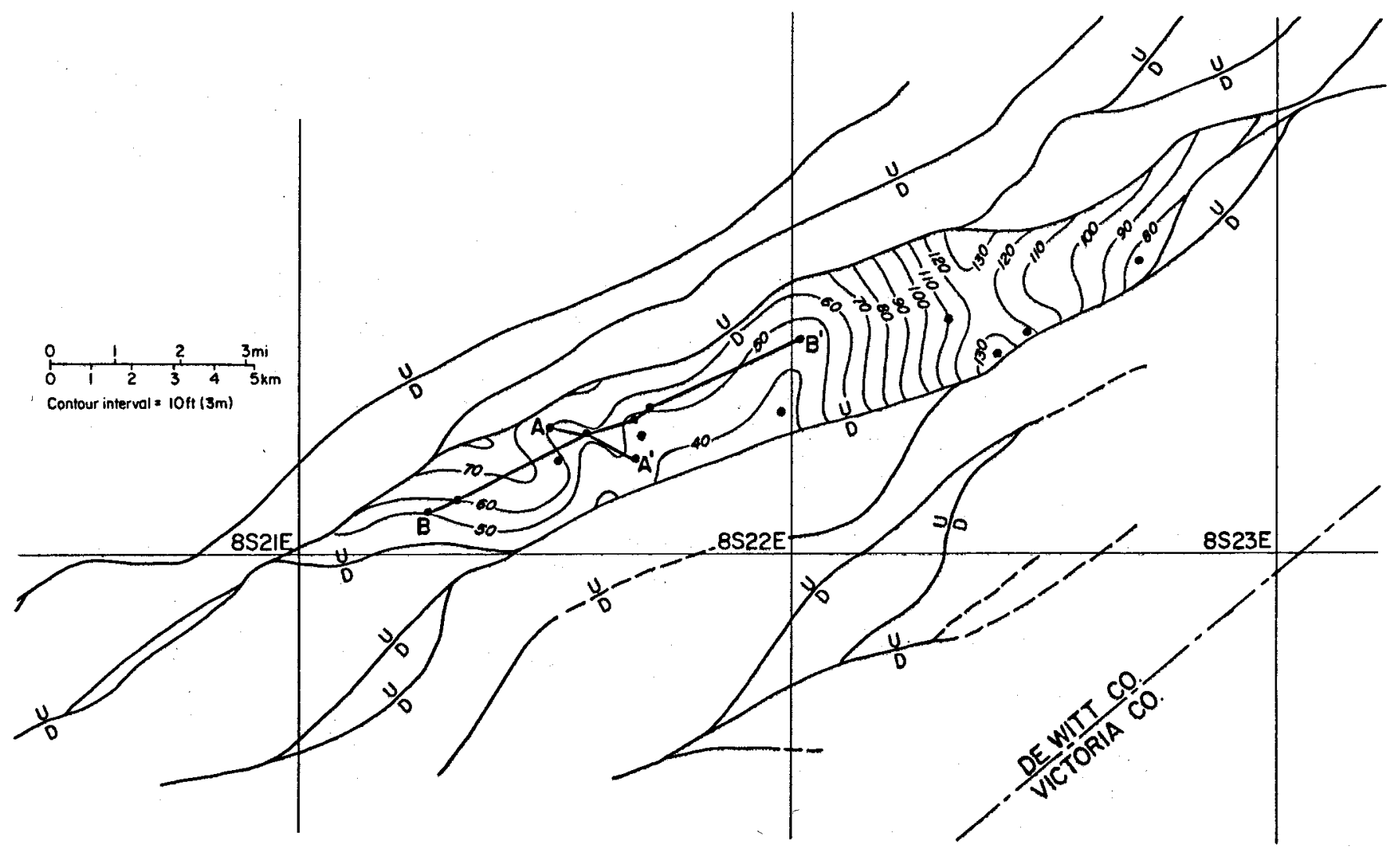

Figure 117. Net sandstone in correlation unit E, Cuero Prospect. 


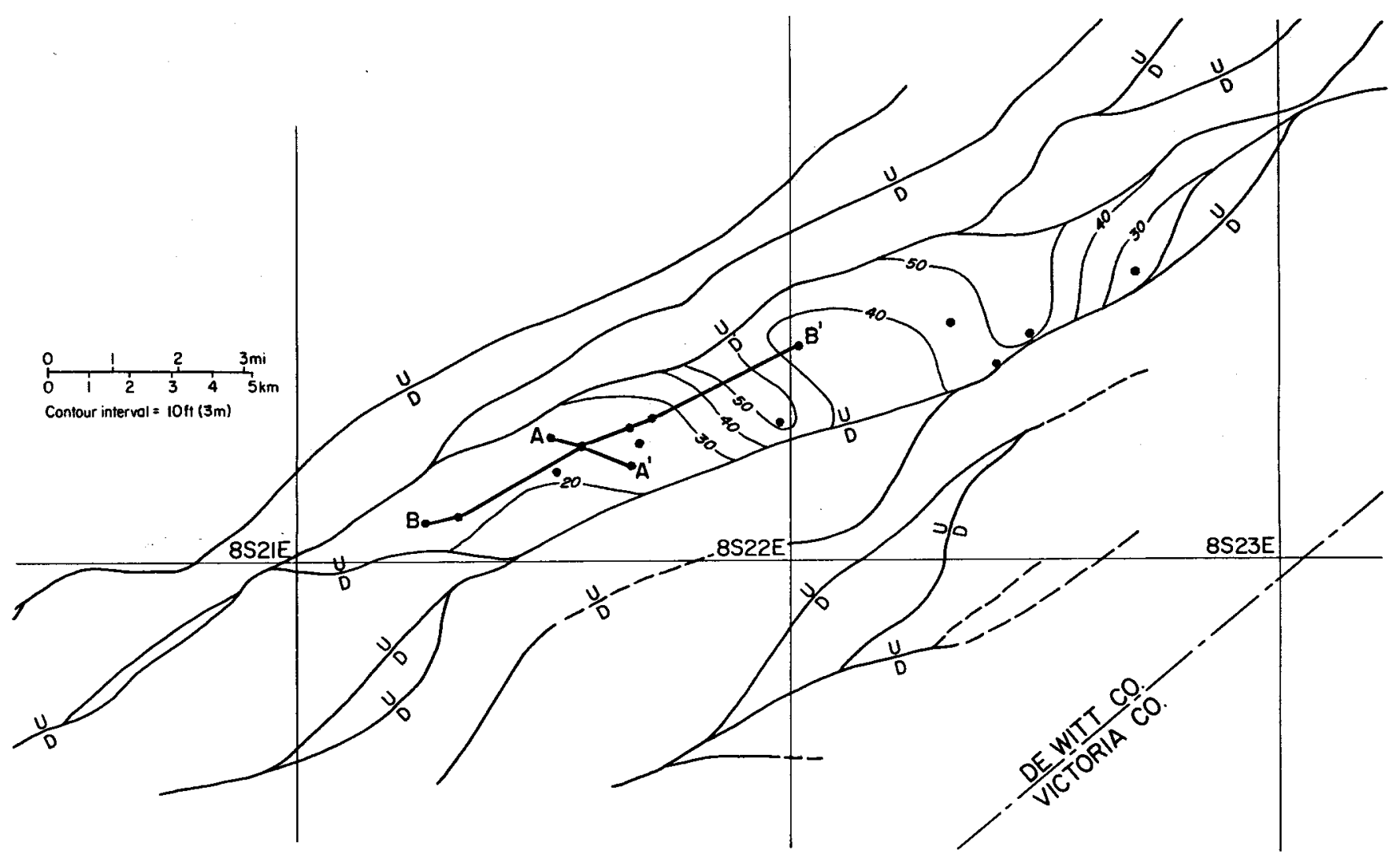

Figure 118. Net sandstone in correlation unit F, Cuero Prospect. 


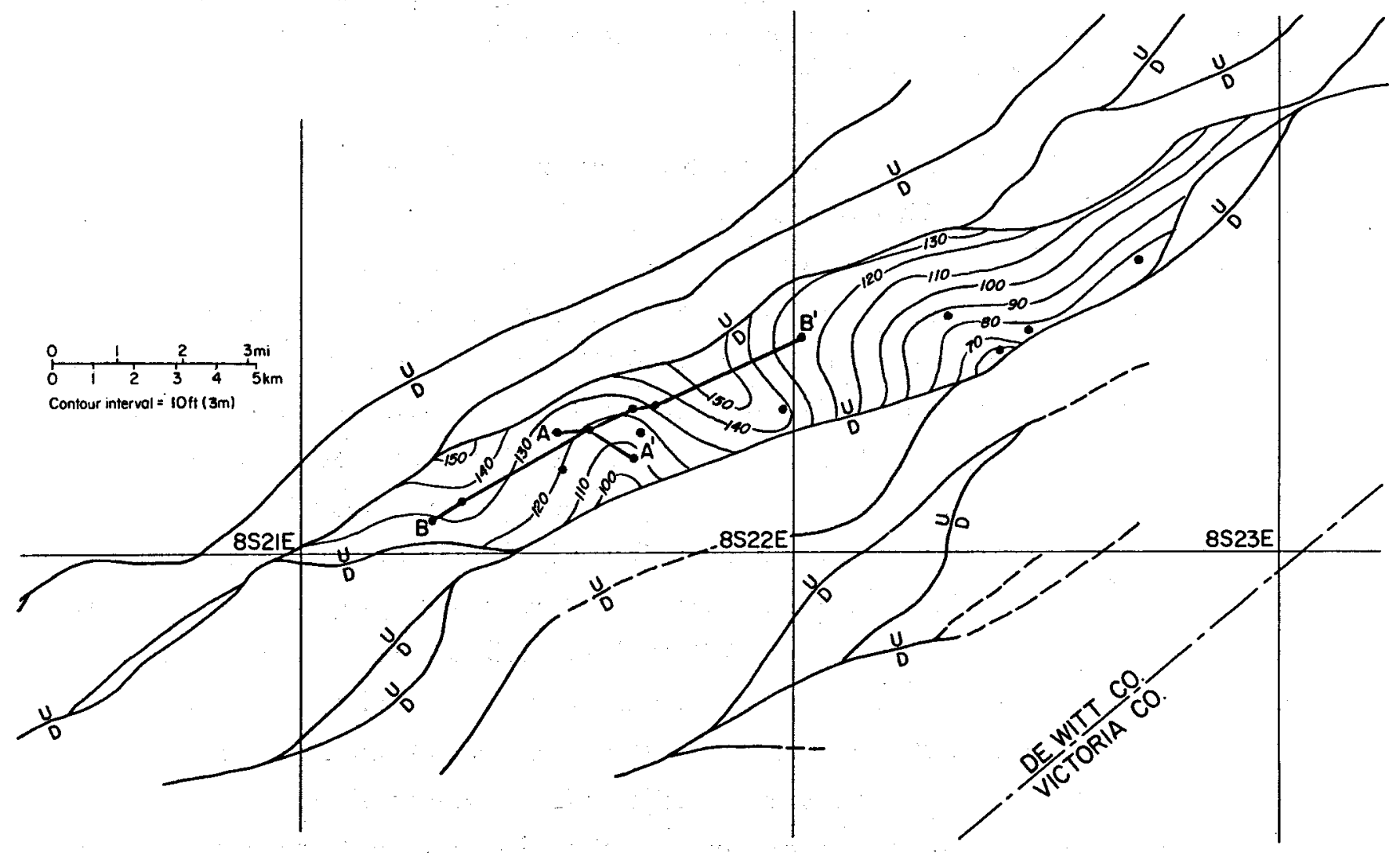

Figure 119. Net sandstone in correlation unit G, Cuero Prospect. 
The Colorado Fairway contains a number of thick, lower Wilcox sandstone units with temperatures greater than $149^{\circ} \mathrm{C}\left(300^{\circ} \mathrm{F}\right)$, but these units generally are only slightly geopressured and have low permeabilities.

The Colorado Fairway extends over approximately $1,140 \mathrm{~km}^{2}\left(440 \mathrm{mi}^{2}\right)$ in parts of Colorado, Austin, and Wharton Counties (fig. 120). The area was recognized as a geopressured geothermal fairway in the study of the Texas Gulf Coast Wilcox Group by Bebout, Gavenda, and Gregory (1978). A thick section of sandstones, with netsandstone values of 370 to $490 \mathrm{~m}(1,200$ to $1,600 \mathrm{ft})$ occurs in the lower Wilcox in parts of the fairway (fig. 33). Although most of the wells in the area do not penetrate the geopressured zone, certain wells show that the deepest sandstones of the lower Wilcox are geopressured and have fluid temperatures greater than $149^{\circ} \mathrm{C}\left(300^{\circ} \mathrm{F}\right)$.

The Wilcox section in the Colorado Fairway is similar to that of the De Witt Fairway; the upper and lower Wilcox, intervals of thick sandstones, are separated by the more shaly section of the middle Wilcox (fig. 121). A correlation marker, Cl, occurs near the base of the sandy section of the upper Wilcox and can be carried into other fairways. This marker is the "regional marker" shown on the regional cross sections (figs. 10 through 32) and is the stratigraphic equivalent of Dl in the De Witt Fairway and $\mathrm{H} 1$ in the Harris Fairway, for examples. Three other Wilcox stratigraphic markers, C2, C3, and C4 were carried within the Colorado Fairway (fig. 121); the C3 marker, which corresponds stratigraphically to the $\mathrm{H} 3$ marker in the Harris Fairway, was the only one of these three markers to be traced outside the Colorado Fairway.

The $\mathrm{C} 4$ marker occurs at depths 49 to $76 \mathrm{~m}$ (160 to $250 \mathrm{ft}$ ) above the top of the lower Wilcox shown on the regional cross sections 13 and 14 (figs. 22 and 23). Throughout most of the Colorado Fairway, the lower Wilcox shows massive sandstones. Rapid facies changes, however, in addition to faults and sparse deep well control, make the lower Wilcox section difficult to correlate. Only within the prospect area was the lower Wilcox subdivided.

Down-to-the-coast faults are common in the Colorado Fairway, as shown by the structure map of the $\mathrm{C}_{4}$ marker (fig. 122) and cross sections $A A^{\prime}, B^{\prime}$, and $C^{\prime}$ ' (figs. 123,124, and 125). The very large Wilcox growth faults characteristic of the fairways of the Lower Texas Gulf Coast, however, are lacking in the Colorado Fairway. Growth faults affecting the lower Wilcox probably exist but are not detected because of the sparse deep well control. 


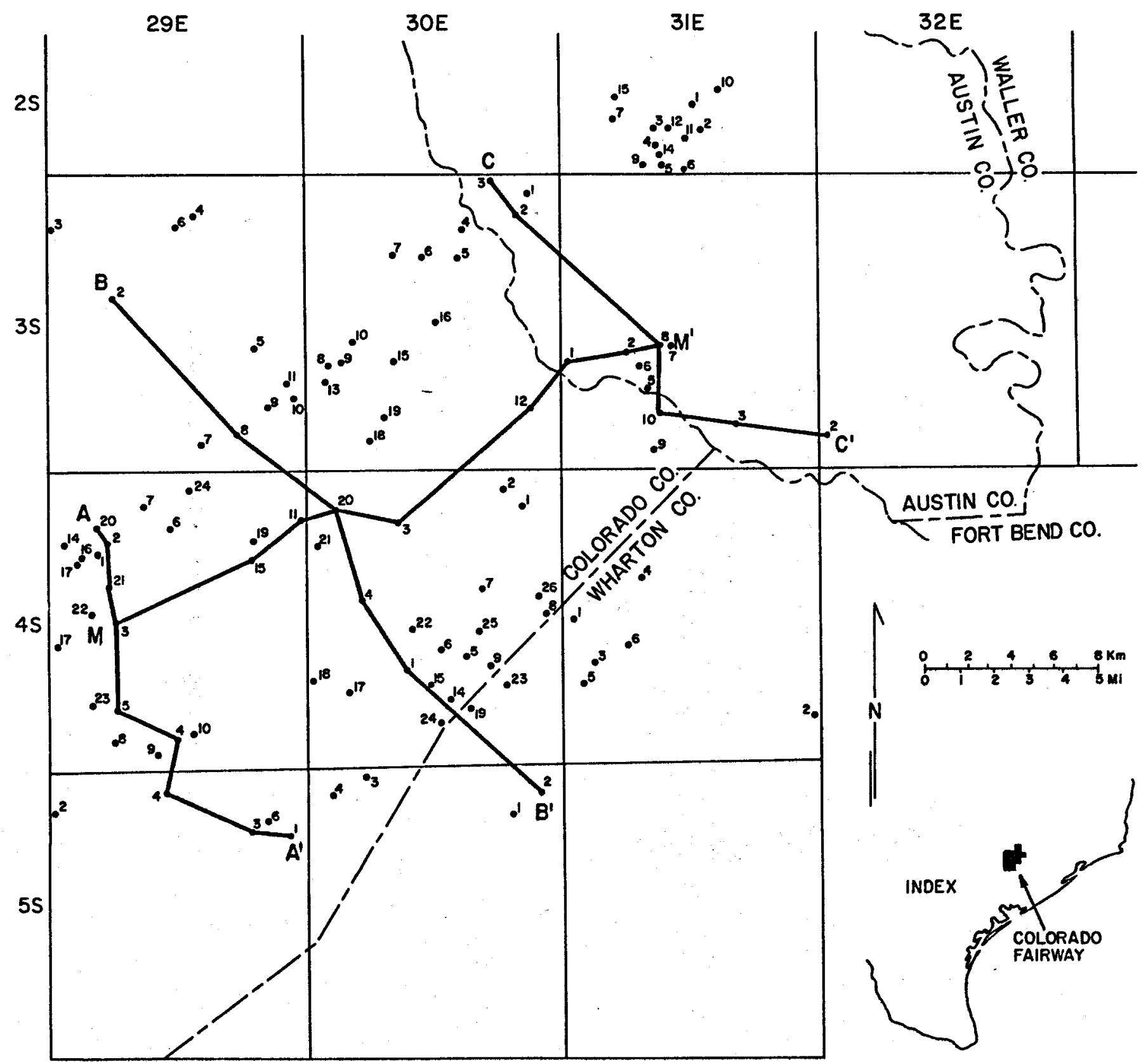

Figure 120. Location of wells and lines of section, Colorado Fairway. 


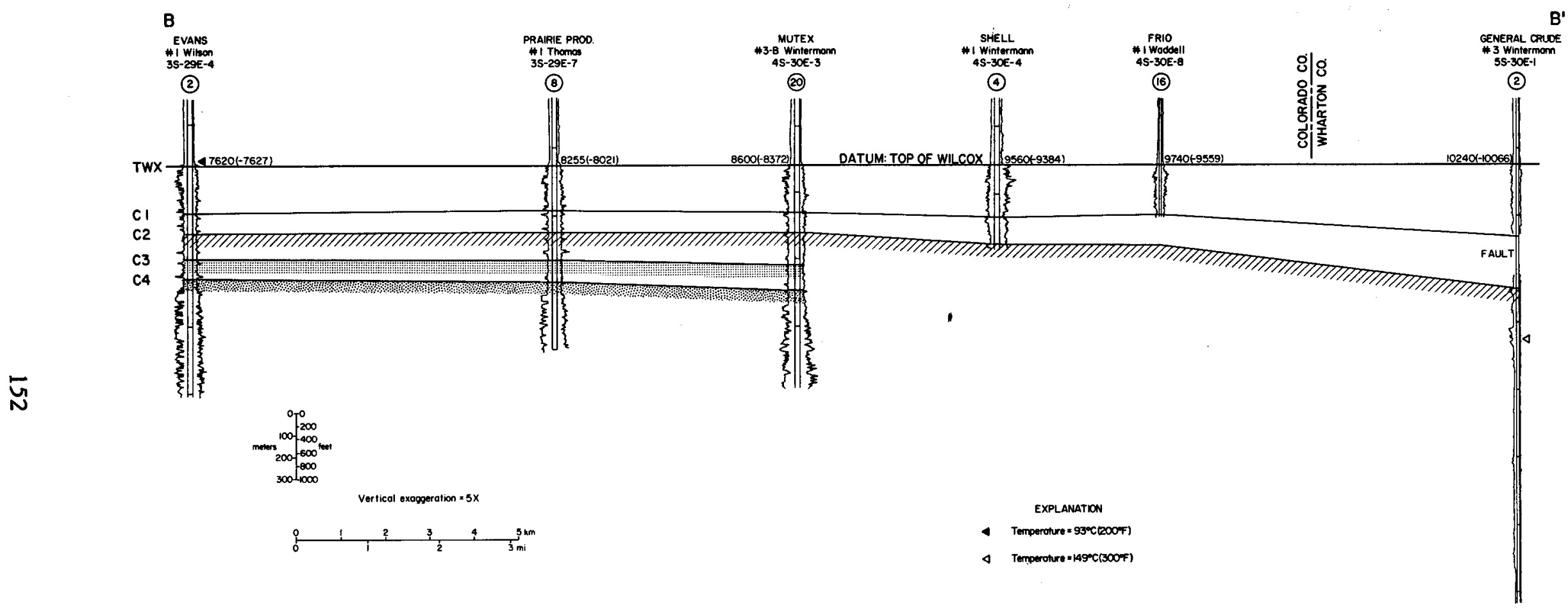

Figure 121. Stratigraphic dip section BB, Colorado Fairway. 


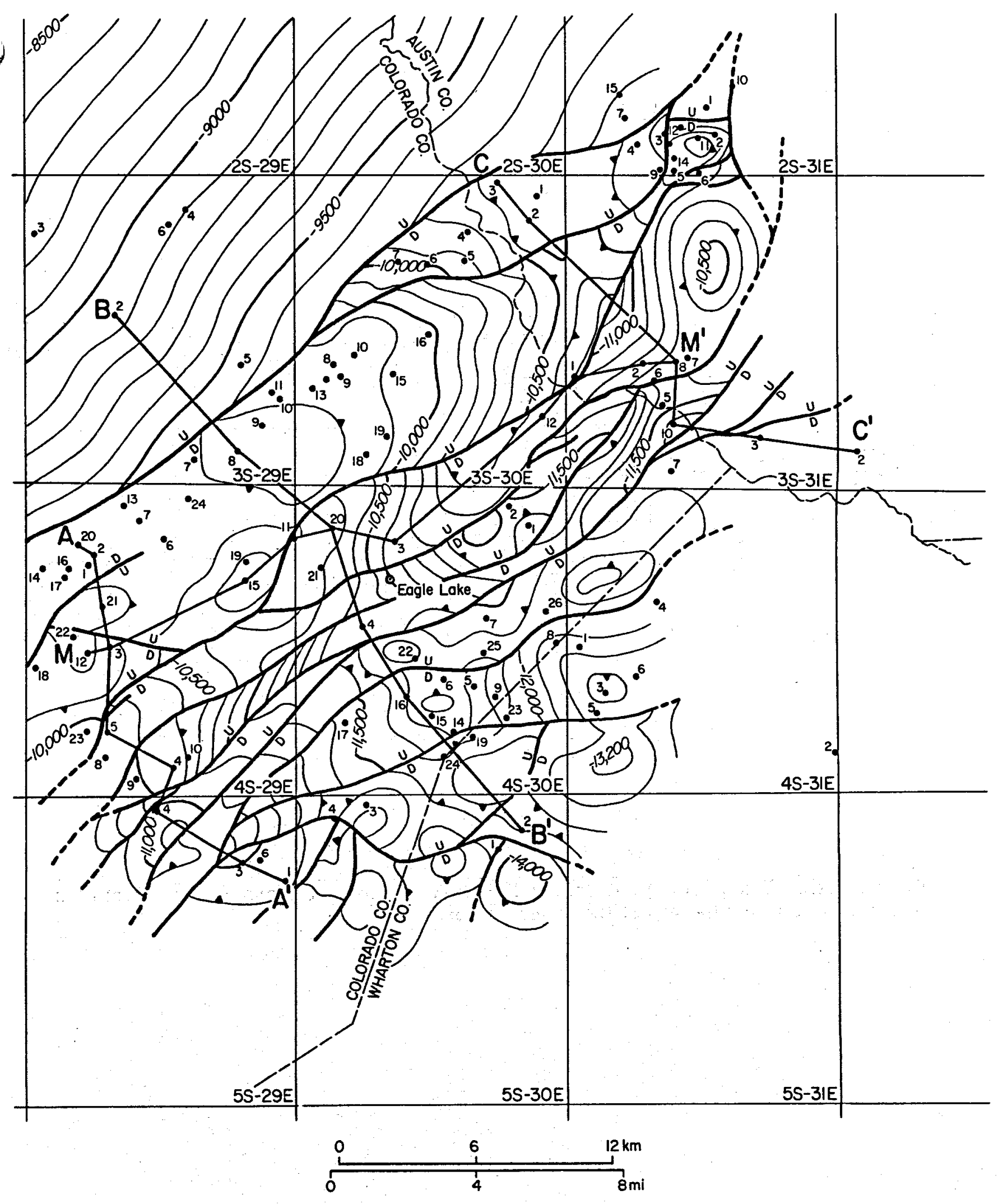

Figure 122a. Structural map, Colorado Fairway. 
B

$3 S-29 E-4$

(2) $3 S-29 E-7$

4S-30E-3

4S-3OE-4

$B^{\prime}$

(8)

(20)

(4)

4S-30E-8 :ं8

5S-3OE-1

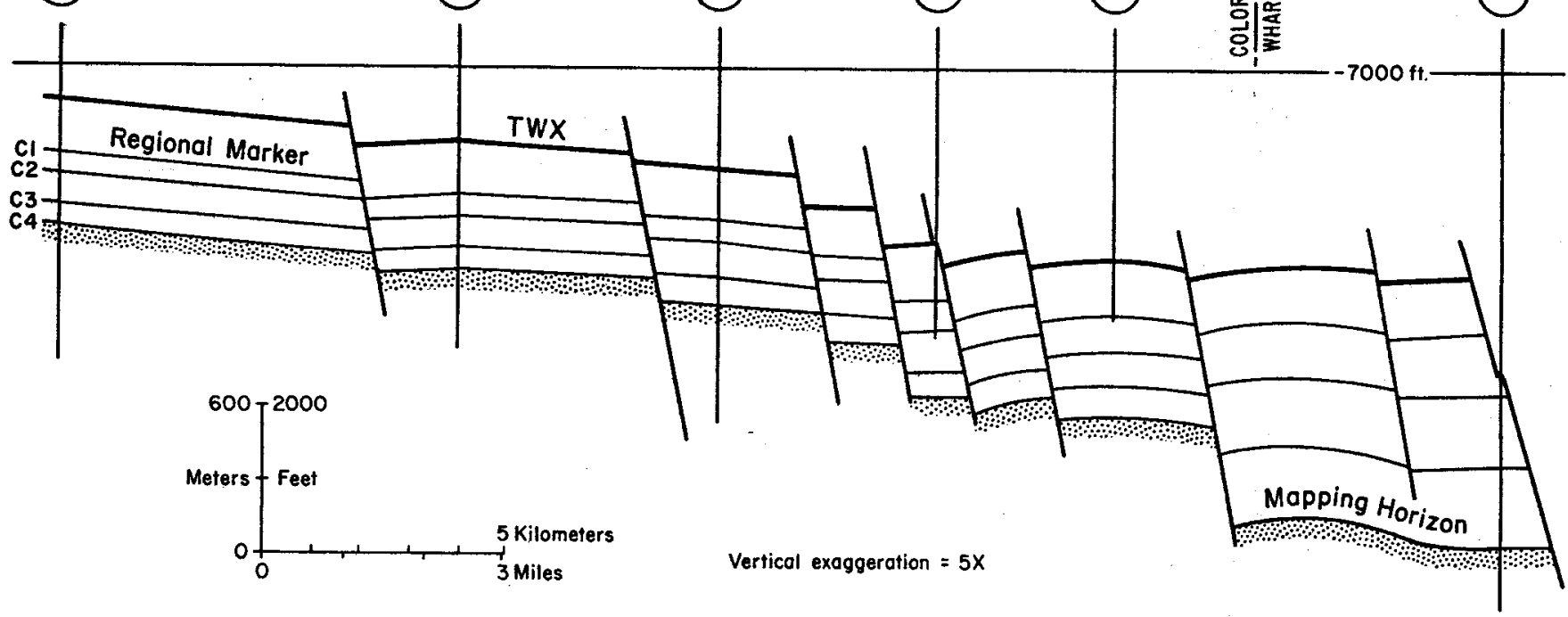

Figure 122b. Index section, Colorado Fairway. Mapping horizon is the $\mathrm{C} 4$ marker, which approximates the top of the lower Wilcox. 


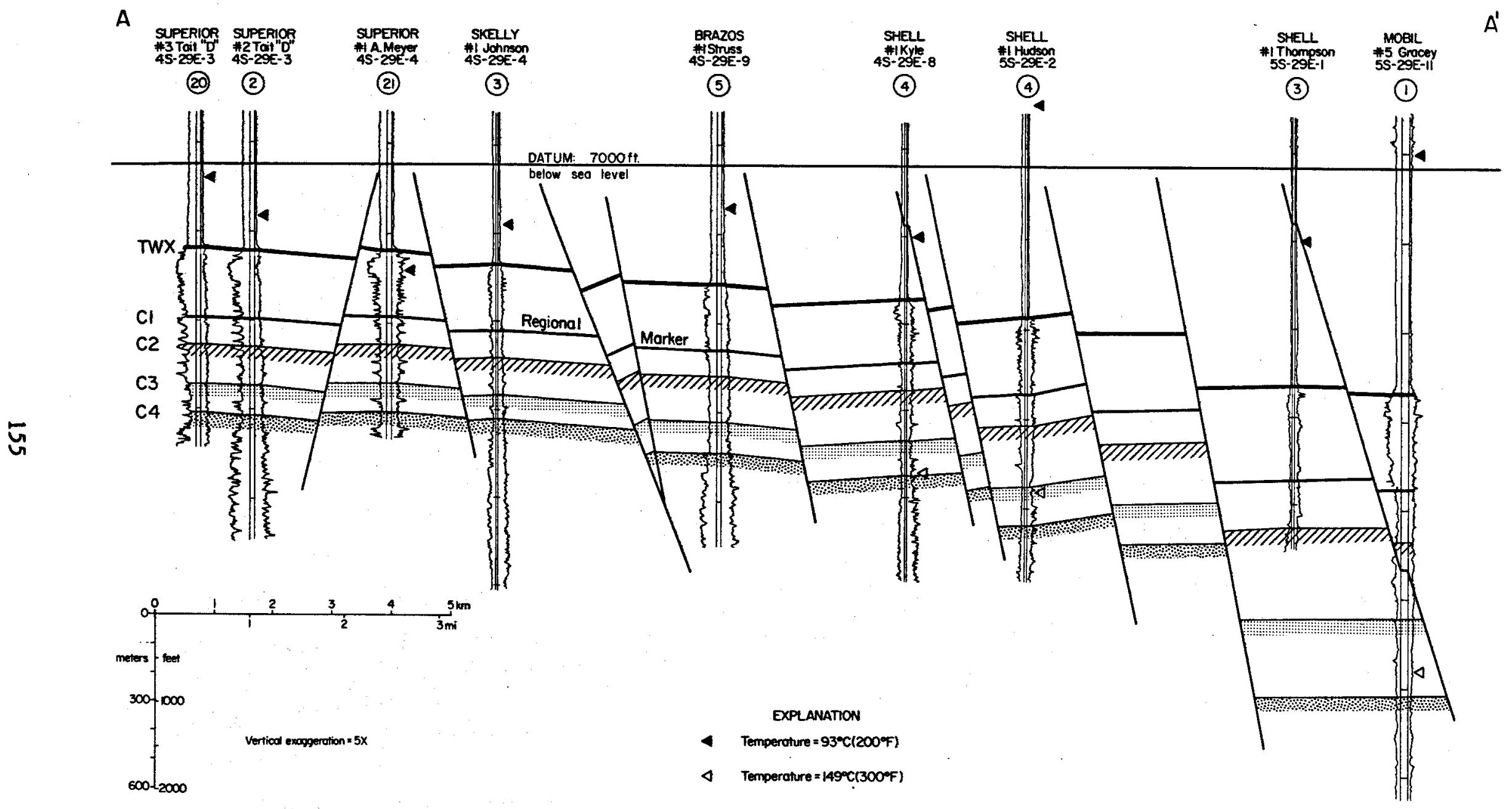

Figure 123. Structural dip section $A A^{\prime}$, Colorado Fairway. 


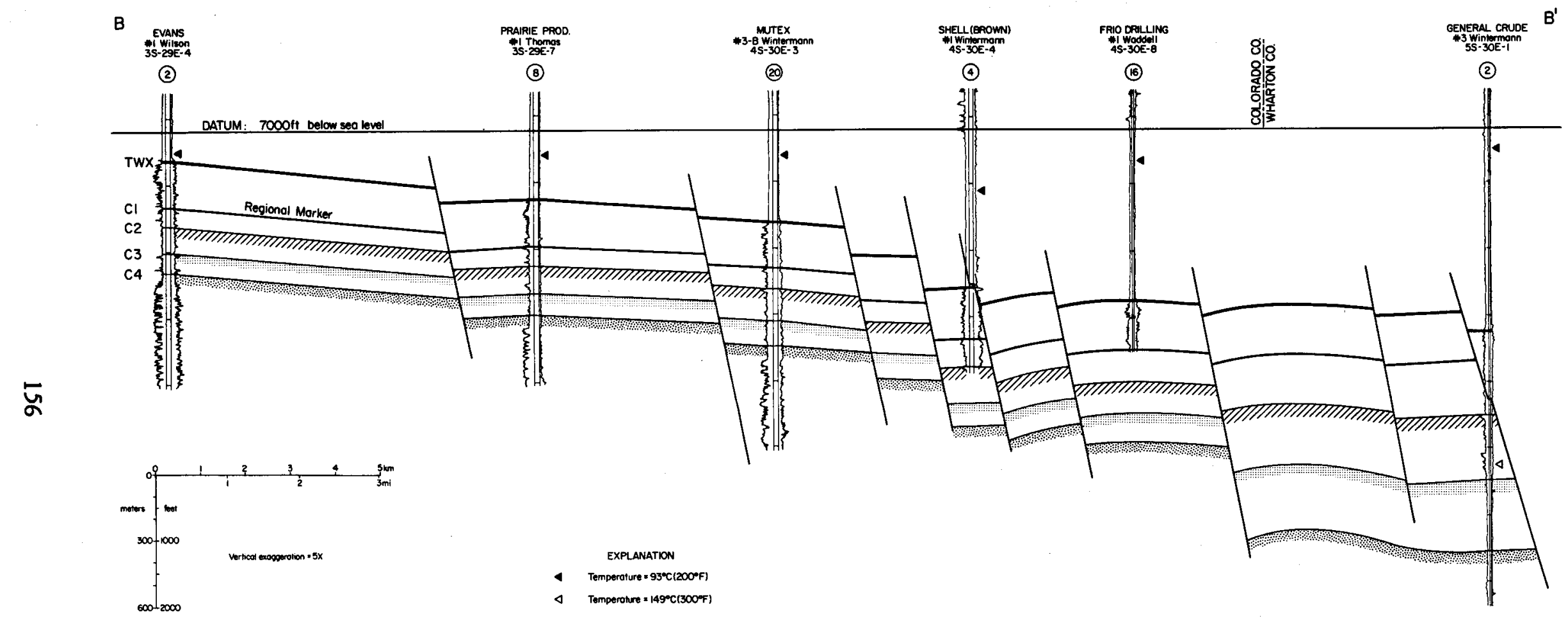

Figure 124. Structural dip section BB', Colorado Fairway.

0 


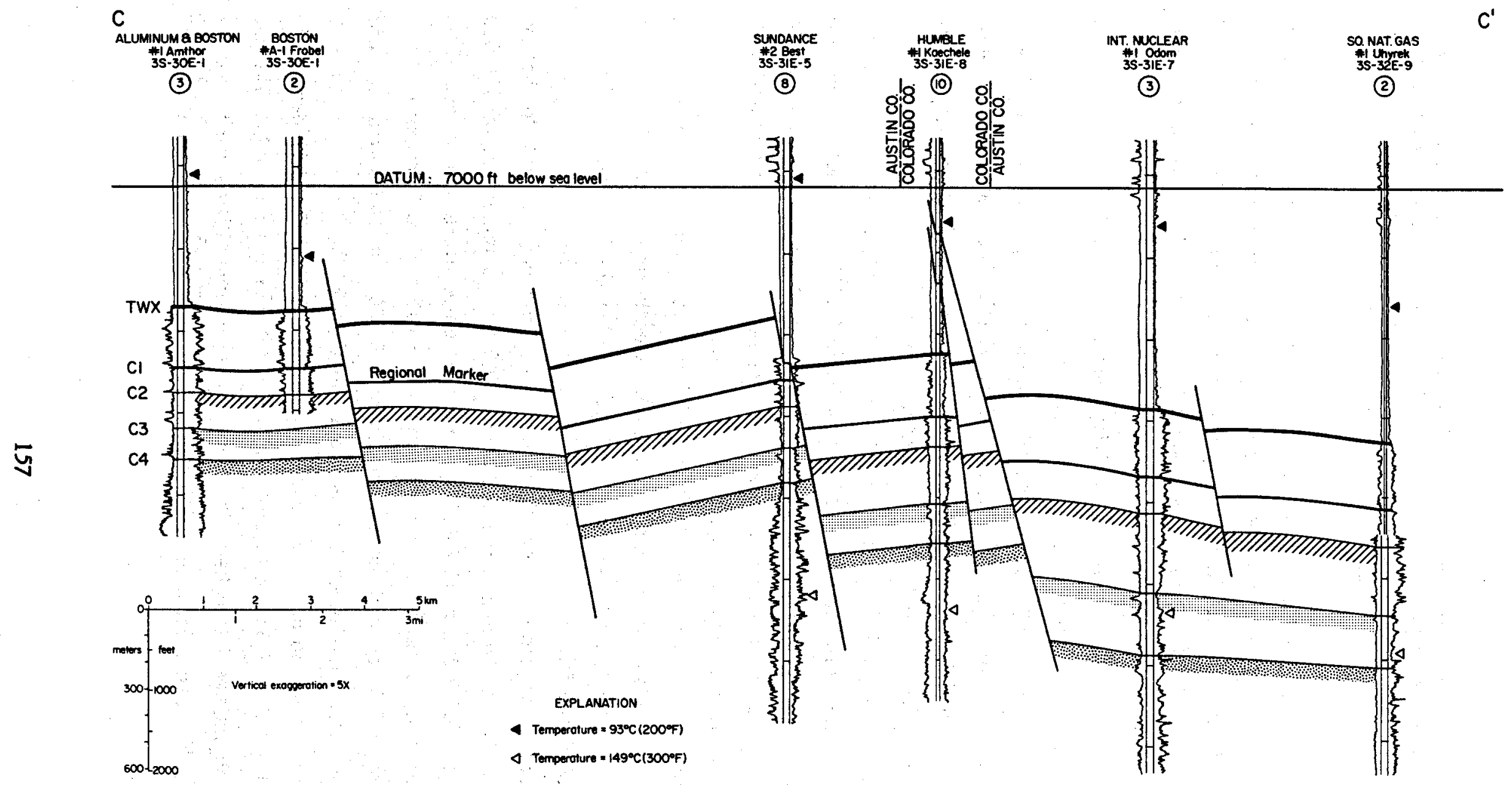

Figure 125. Structural dip section CC', Colorado Fairway. 
In the Colorado Fairway, pressure gradients are generally low, temperatures of $149^{\circ} \mathrm{C}$ $\left(300^{\circ} \mathrm{F}\right)$ occur at an average depth of $3,800 \mathrm{~m}(12,467 \mathrm{ft})$, porosities range between 4 and 30 percent, and permeabilities commonly are less than $5 \times 10^{-3} \mu^{2}(5 \mathrm{md})$ but may be over $500 \times 10^{-3} \mu^{2}(500 \mathrm{md})$ in isolated thin sandstone units.

Many wells in Colorado County are not geopressured. Some wells are only slightly geopressured, possibly because they were not drilled deep enough to penetrate formations with higher pressures. Shale resistivity-versus-depth plots for six selected wells are typical of wells in the Colorado Fairway (figs. 126 to 131). The Mutex 非-B Wintermann, located on cross section BB' (fig. 124), was a dry hole drilled to a total depth of $3,659 \mathrm{~m}(12,005 \mathrm{ft})$. Shale resistivity data show no evidence of high geopressures and this conclusion is confirmed by low mud weights used in drilling (fig. 126). The Union \#A-1 Thomas (fig. 127), located on cross section MM' (fig. 136), was also a dry hole drilled to a total depth of 3,627 $\mathrm{m}(11,901 \mathrm{ft})$. The maximum pressure gradient, based on mud weight used in this type well for the Eagle Lake Prospect, was $14.34 \mathrm{kPa} / \mathrm{m}$ (0.634 psi/ft). The Skelly \#1 Wintermann (fig. 128), located on cross section MM' (fig. 136), was drilled to a total depth of 3,390 m (11,122 ft). Evidence of a cap rock exists in the depth interval 2,591 to $3,231 \mathrm{~m}(8,500$ to $10,600 \mathrm{ft})$ but the well does not penetrate geopressured zones. Three additional wells with shale resistivity plots (figs. 129 to 131), not located on cross sections, were all drilled with low mud weights and did not encounter geopressured formations.

An equilibrium temperature of $149^{\circ} \mathrm{C}\left(300^{\circ} \mathrm{F}\right)$ occurs at an average depth of $3,801 \mathrm{~m}(12,470 \mathrm{ft}$ ) in Colorado County (fig. 132). Geothermal gradients average $2.59^{\circ} \mathrm{C} / 100 \mathrm{~m}\left(1.40^{\circ} \mathrm{F} / 100 \mathrm{ft}\right)$ to $2,438 \mathrm{~m}(8,000 \mathrm{ft})$. Below $2,438 \mathrm{~m}$ the gradient is $4.87^{\circ} \mathrm{C} / 100 \mathrm{~m}\left(2.67^{\circ} \mathrm{F} / 100 \mathrm{ft}\right)$.

Salinities were computed only for the Union \#A-1 Thomas (fig. 133). In shallow formations, values of salinity increase from about 19,000 to a maximum of 180,000 ppm $\mathrm{NaCl}$ at a depth of $2,042 \mathrm{~m}(6,700 \mathrm{ft})$ where the temperature approaches $93^{\circ} \mathrm{C}$ $\left(200^{\circ} \mathrm{F}\right)$. Below $2,042 \mathrm{~m}$, salinities decline to a minimum value of $55,000 \mathrm{ppm} \mathrm{NaCl}$ at a depth of $2,896 \mathrm{~m}(9,500 \mathrm{ft})$ then increase again to $180,000 \mathrm{ppm} \mathrm{NaCl}$ at a depth of $3,642 \mathrm{~m}(11,950 \mathrm{ft})$ where the temperature is about $150^{\circ} \mathrm{C}\left(302^{\circ} \mathrm{F}\right)$.

Porosities from diamond bit core measurements lie between 4 and 19 percent in the depth interval 3,386 to $3,554 \mathrm{~m}(11,109$ to $11,660 \mathrm{ft})$ in the Union \#A-1 Thomas (fig. 134), type well for the Eagle Lake Prospect. Most permeabilities are below $5 \times$ $10^{-3}{\mu \mathrm{m}^{2}}^{2}(5 \mathrm{md})$. However, permeabilities range from $89 \times 10^{-3}$ to $545 \times 10^{-3} \mu^{2}$ 
(89 to $545 \mathrm{md}$ ) and average $275 \times 10^{-3} \mu \mathrm{m}^{2}(275 \mathrm{md})$ in the thin sandstone interval between 3,541.8 and 3,543 $\mathrm{m}(11,620$ and $11,624 \mathrm{ft})$. There are several other isolated thin sandstones with permeabilities from $10 \times 10^{-3}$ to $100 \times 10^{-3} \mu^{2}$ (10 to $100 \mathrm{md}$ ). Average porosity and permeability in the depth interval 3,000 to $3,003.5 \mathrm{~m}(9,840$ to $9,854 \mathrm{ft}$ ) in the Shell \#1 Engstrom (5S-29E-9) $27 \mathrm{~km}(17 \mathrm{mi})$ to the southwest of the prospect area was 15.9 percent and $16.8 \times 10^{-3}{\mu \mathrm{m}^{2}}^{2}(16.8 \mathrm{md})$. Sidewall core measurements from several wells indicate porosities of 20 to 30 percent and permeabilities up to $450 \times 10^{-3} \mu^{2}(450 \mathrm{md})$ in sandstone intervals occurring between 2,438 and $3,353 \mathrm{~m}(8,000$ and $11,000 \mathrm{ft})$. 


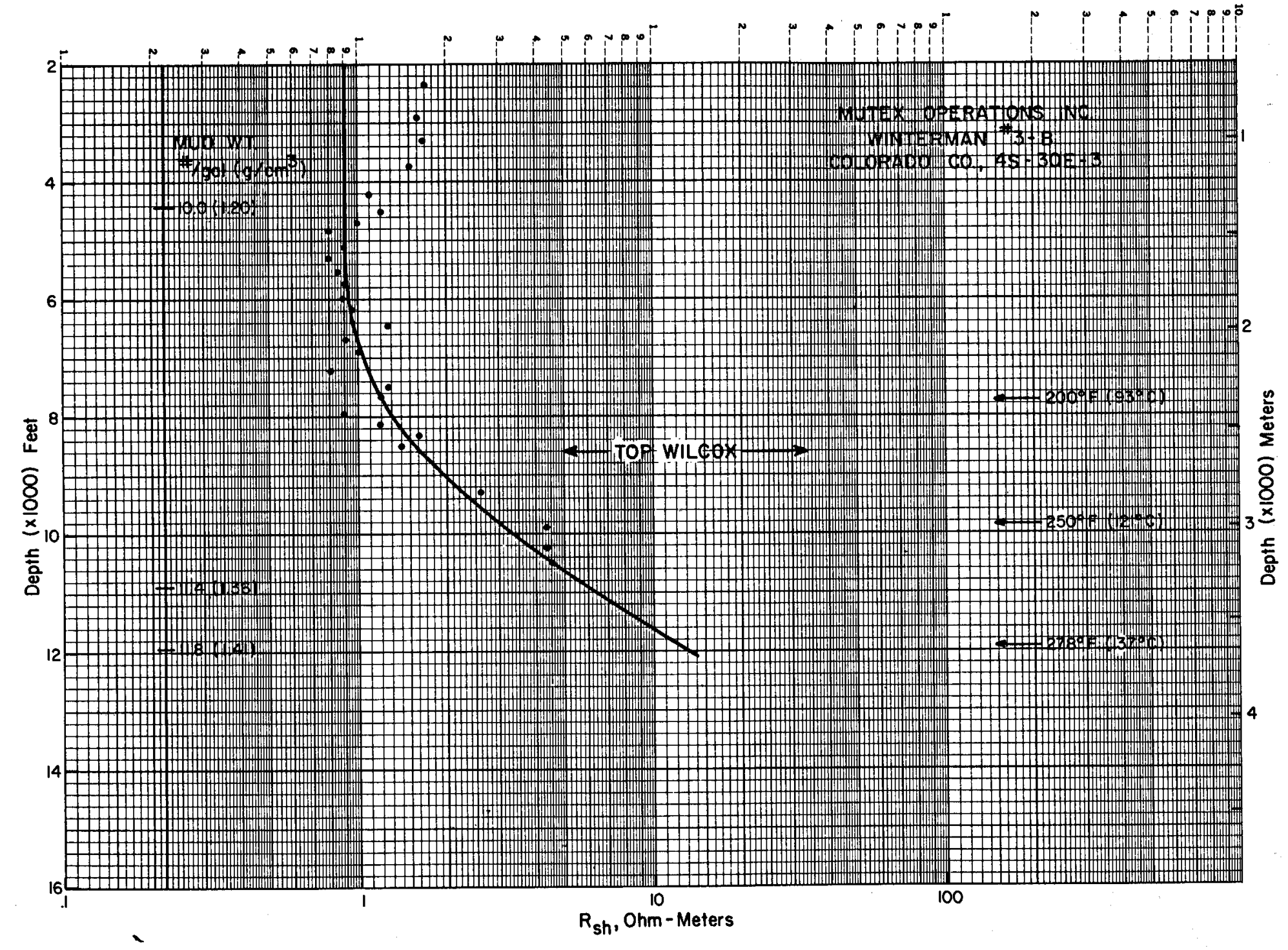

Figure 126. Shale resistivity versus depth for nongeopressured well located on section BB' (fig. 124), Colorado County. 


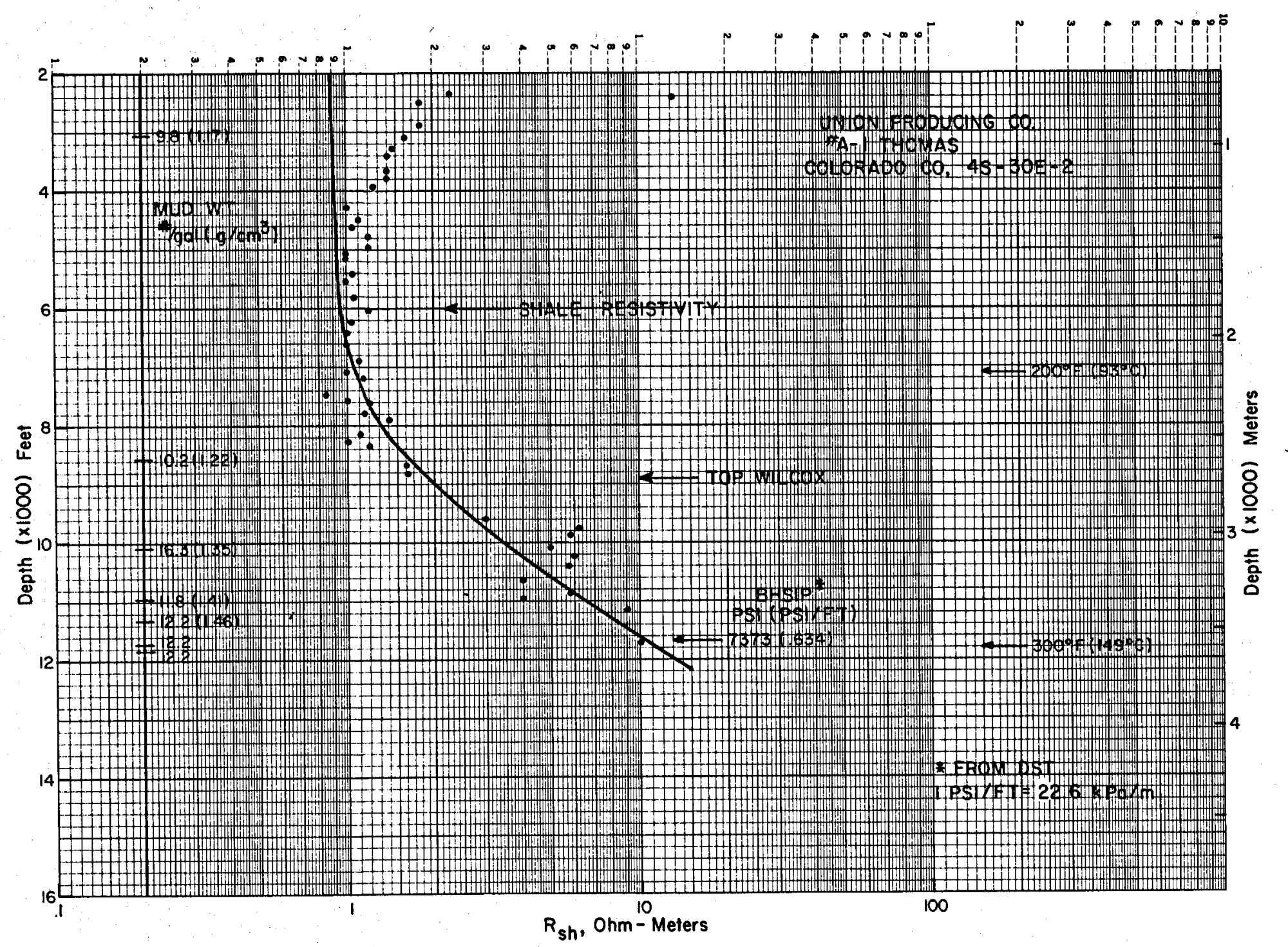

Figure 127. Shale resistivity versus depth for well located on cross section MM' (fig. 136), Colorado County. 


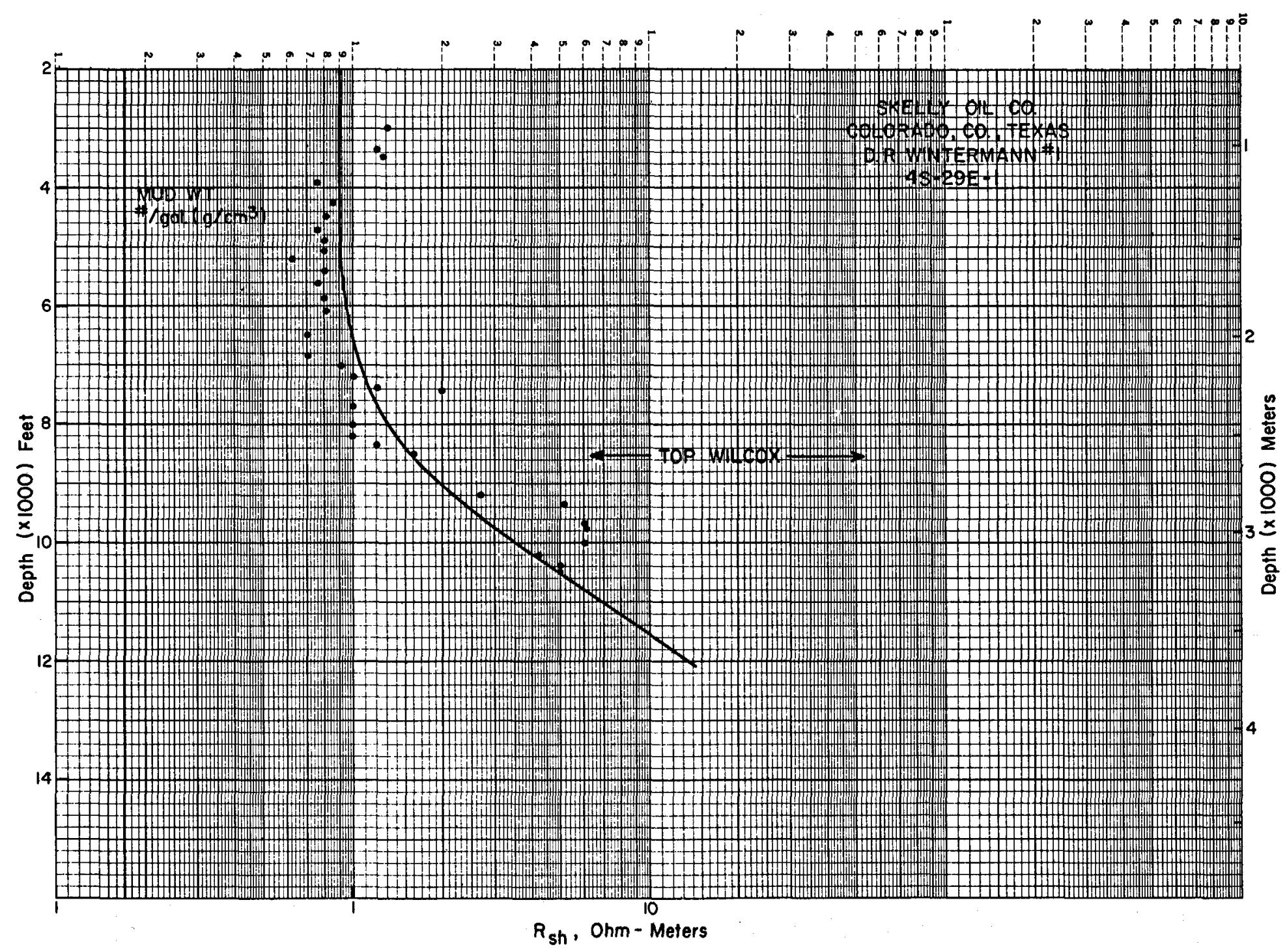

Figure 128. Shale resistivity versus depth for a nongeopressured well located on cross section MM' (fig. 136), Colorado County. 


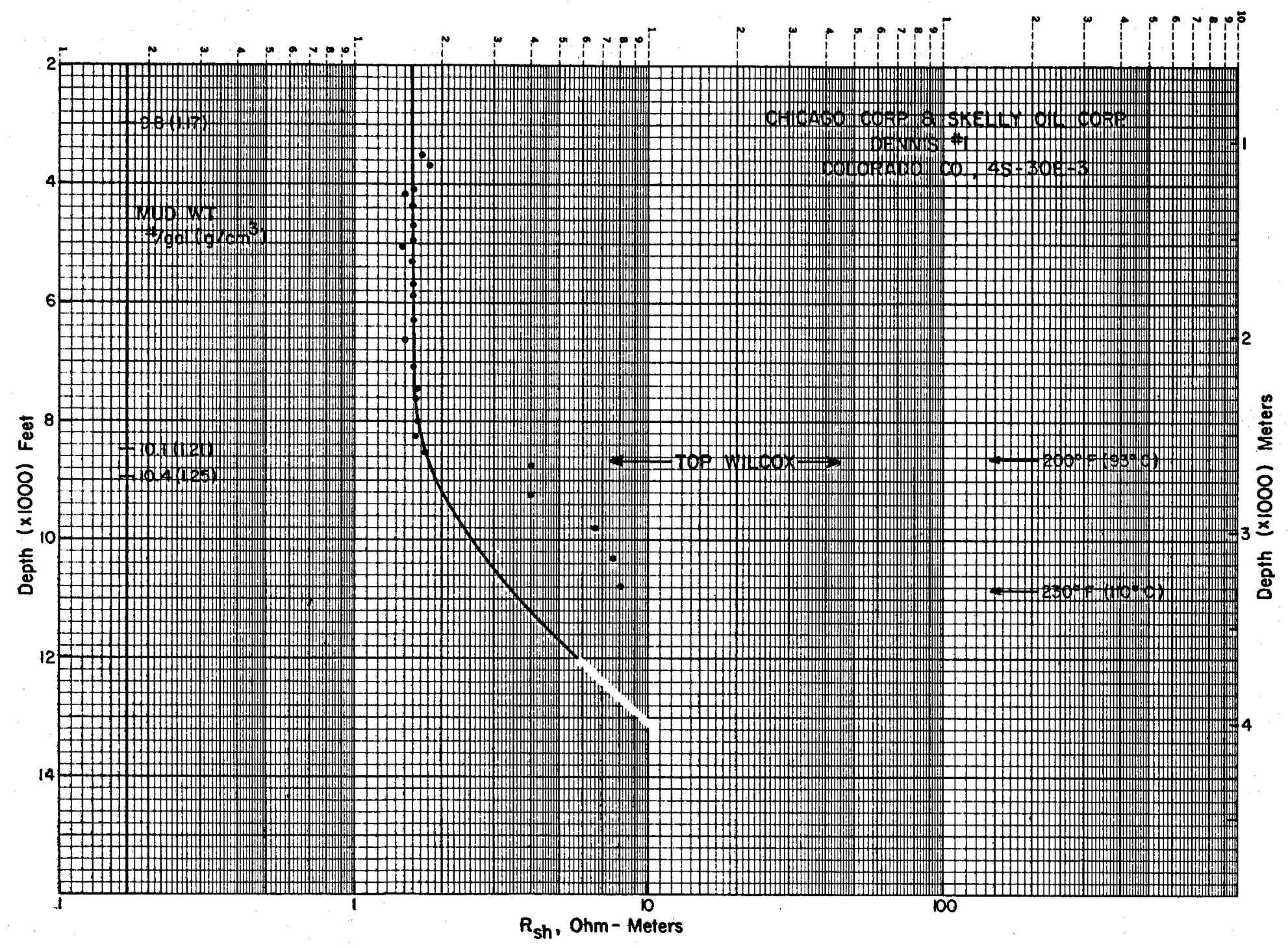

Figure 129. Shale resistivity versus depth for a nongeopressured well in Colorado County. 


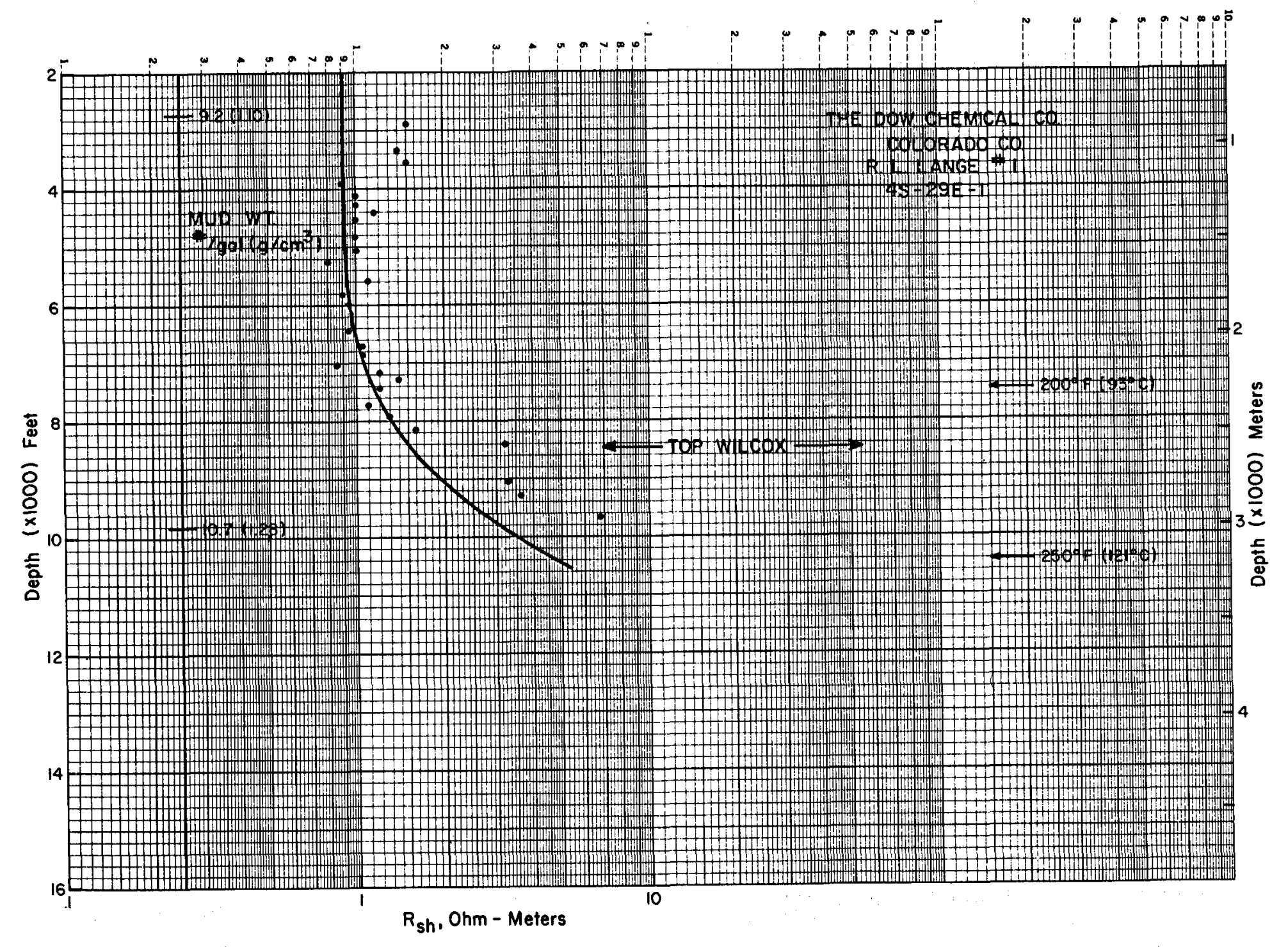

Figure 130. Shale resistivity versus depth for a nongeopressured well in Colorado County. 


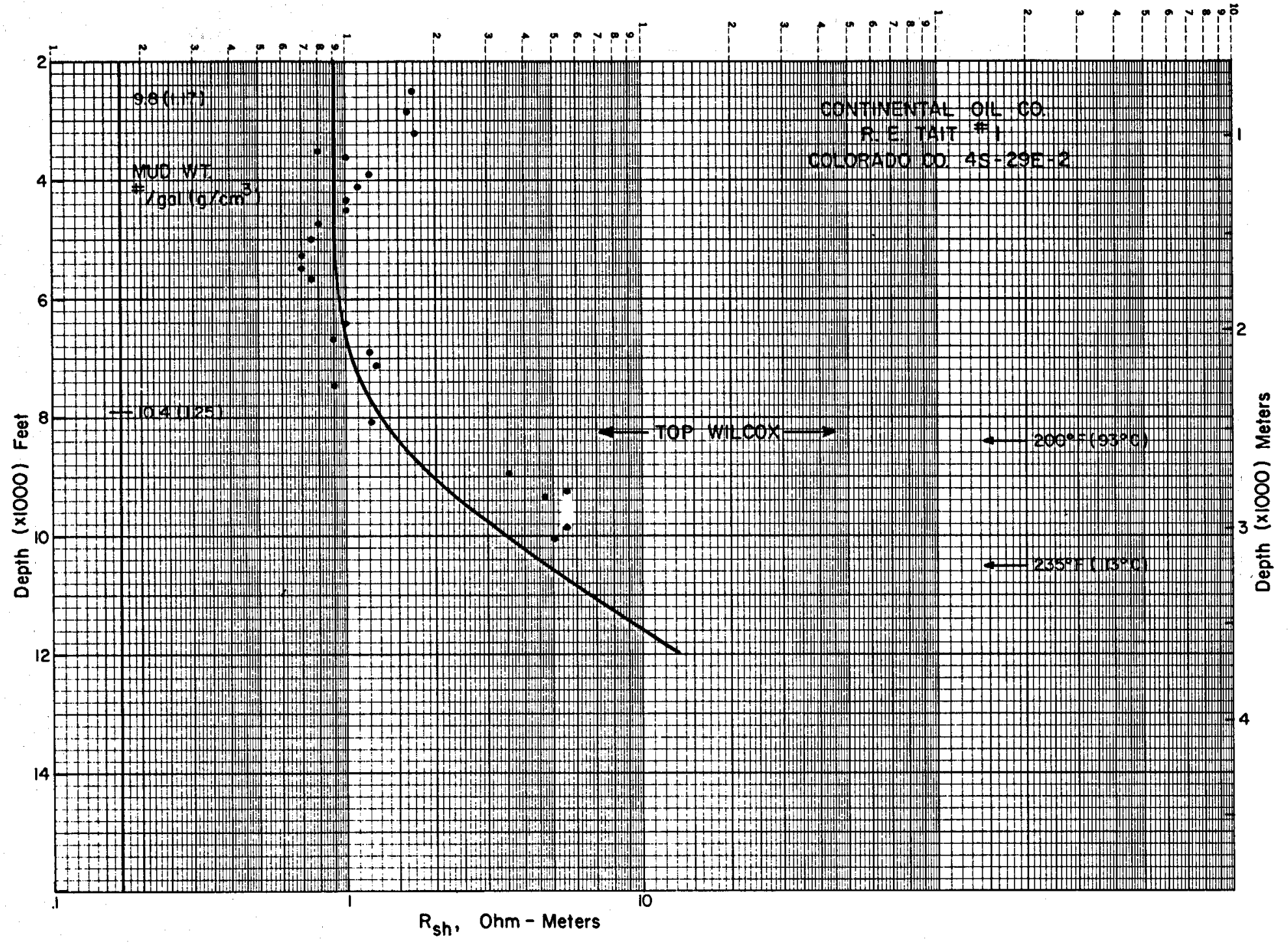

Figure 131. Shale resistivity versus depth for a nongeopressured well in Colorado County. 


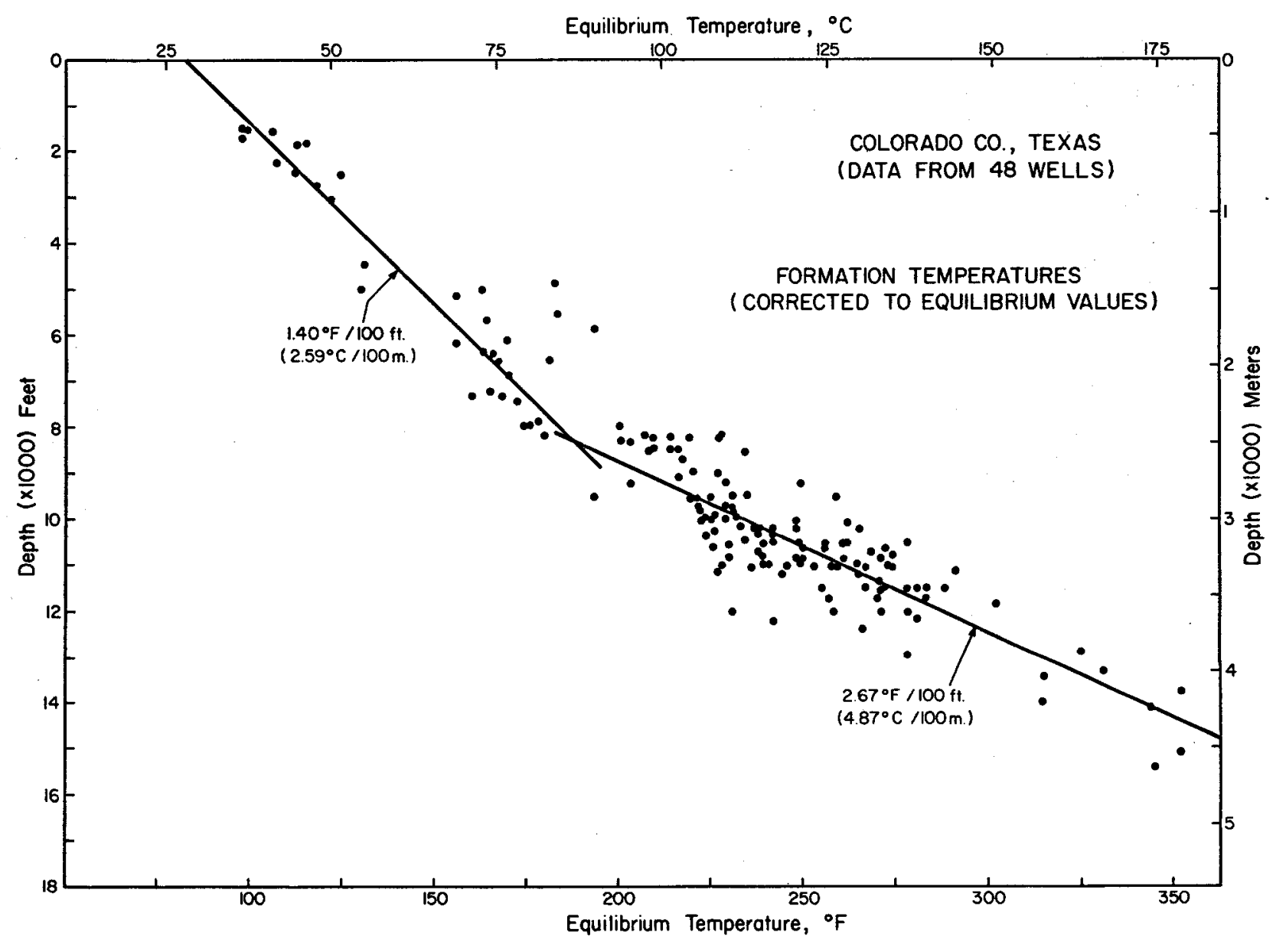

Figure 132. Temperatures and geothermal gradients for 48 wells located in Colorado County. 
2 $N$ $\omega$ n

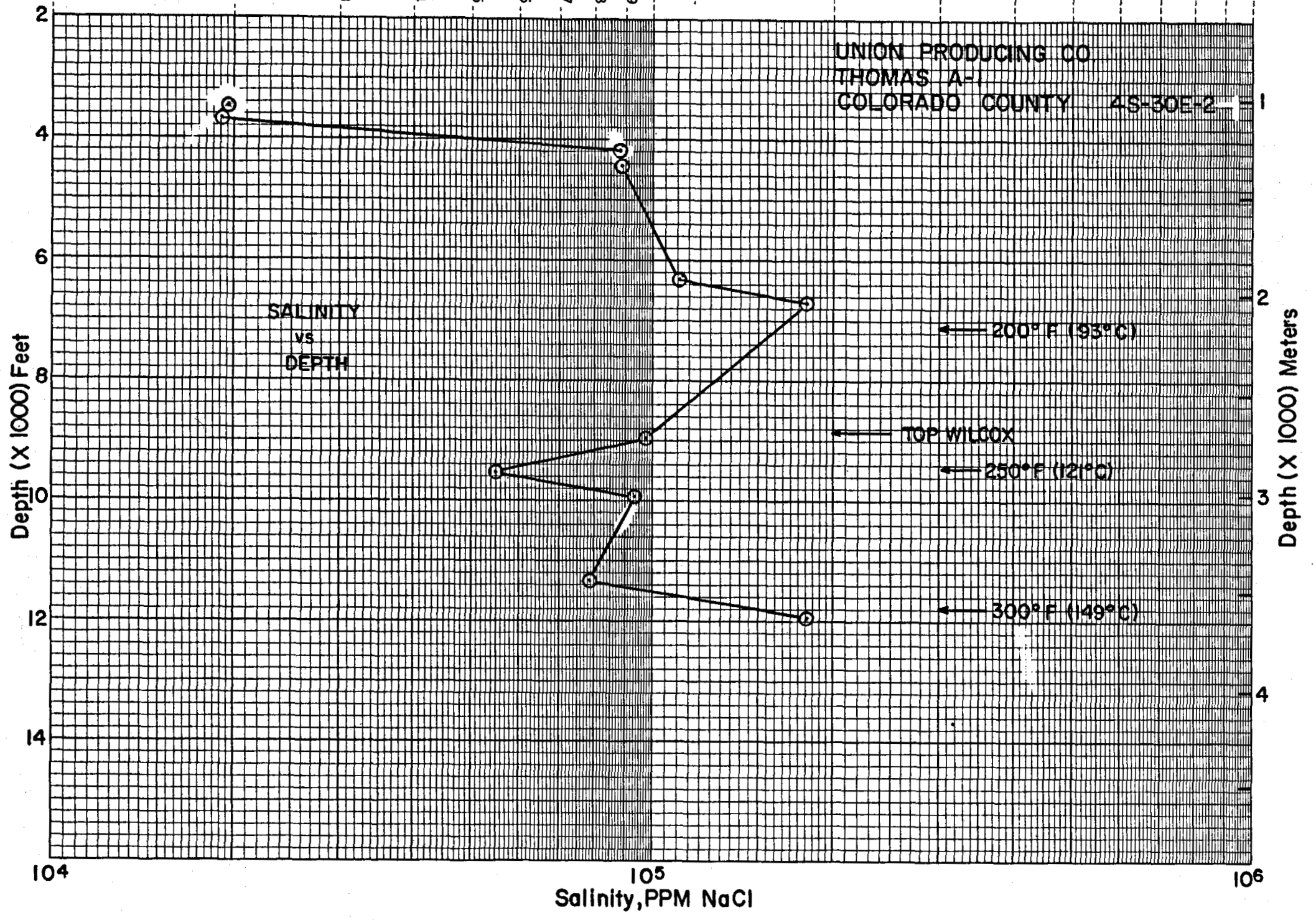

Figure 133. Salinity profile for the type well (Eagle Lake Prospect), located on cross section MM' (fig. 136), Colorado County. 


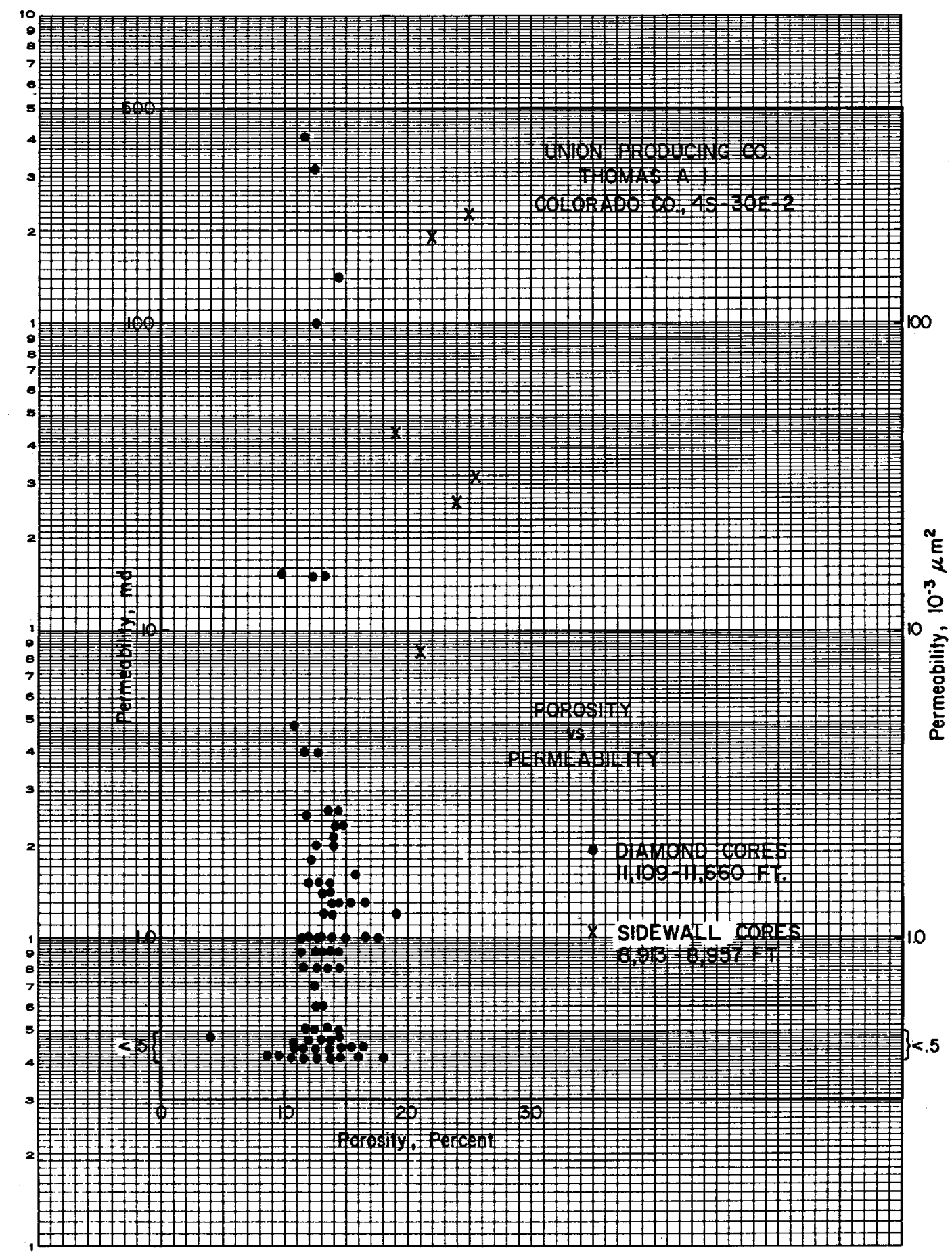

Figure 134. Porosity versus permeability for the type well (Eagle Lake Prospect) located on cross section MM' (fig. 136), Colorado County. 
In the Eagle Lake Prospect of the Colorado Fairway, a site has been selected for a geothermal test well that will have over $366 \mathrm{~m}(1,200 \mathrm{ft})$ of net sandstone in the reservoir interval, with temperatures of $138^{\circ} \mathrm{C}\left(280^{\circ} \mathrm{F}\right)$ to $163^{\circ} \mathrm{C}\left(325^{\circ} \mathrm{F}\right)$ but with generally low permeabilities and fluids that are only slightly geopressured.

The Eagle Lake Prospect extends over an elongate area of approximately $26 \mathrm{~km}^{2}$ $\left(10 \mathrm{mi}^{2}\right.$ ) within the Colorado Fairway in eastern Colorado County (fig. 135). The prospect area is bounded on the northwest and southeast by major faults and on the northeast and southwest by structural highs. A proposed test-well site is located within the Eagle Lake Prospect area 2 mi northeast of the town of Eagle Lake.

The top of the reservoir sandstone in the type well (Union \#A-1 Thomas, fig. 136) for the prospect area is at a depth of $3,410 \mathrm{~m}(11,180 \mathrm{ft})$. Within the prospect area, the top of the reservoir sandstone interval ranges in depth from $3,340 \mathrm{~m}(10,960$ $\mathrm{ft})$ to $3,475 \mathrm{~m}(11,400 \mathrm{ft})$. Although none of the existing wells in the prospect area penetrated the entire prospective interval, wells along strike but several miles from the prospect area indicate the total thickness of the prospective sandstone section to be at least $490 \mathrm{~m}(1,600 \mathrm{ft})$. Trends' of the lower Wilcox sandstone (fig. 134, units $A$ through $F$ ) thickening into the syncline in the prospect area, however, indicate that the total prospective interval may be as much as $580 \mathrm{~m}(1,900 \mathrm{ft})$ thick in the test well (fig. 137). Thus, the base of the reservoir sandstone in the prospect area should be at depths ranging from about 3,840 to $4,060 \mathrm{~m}(12,600$ to $13,300 \mathrm{ft})$. In the test well, the reservoir sandstone should occupy the interval from 3,440 to $4,020 \mathrm{~m}(11,280$ to 13,180 ft).

On the basis of the sandstone percentage in the prospective interval of the type well, the total interval thickness in adjacent areas, and thickening of the section into the syncline, the net sandstone in the prospective reservoir of the test well is expected to be approximately $380 \mathrm{~m}(1,240 \mathrm{ft})$. The sandstone beds range in thickness from 2.5 to $21 \mathrm{~m}(8$ to $70 \mathrm{ft})$, and the intervening shale beds are from 1.5 to $12 \mathrm{~m}(5$ to $40 \mathrm{ft}$ ) thick.

Whole-core analyses from the prospective interval in the type well show that porosity ranges from 4 to 19 percent and averages 13 percent. Most of the reservoir sandstone section is characterized by low permeabilities less than $5 \times 10^{-3} \mu \mathrm{m}^{2}(5 \mathrm{md})$; high permeabilities up to $545 \times 10^{-3} \mu \mathrm{m}^{2}(545 \mathrm{md})$ are found only in the core taken from $3,536 \mathrm{~m}(11,600 \mathrm{ft})$ to $3,554 \mathrm{~m}(11,660 \mathrm{ft})$. 
In the type well, fluid temperatures of $93^{\circ} \mathrm{C}\left(200^{\circ} \mathrm{F}\right)$ and $149^{\circ} \mathrm{C}\left(300^{\circ} \mathrm{F}\right)$ occur at depths of $1,860 \mathrm{~m}(6,100 \mathrm{ft})$ and $3,590 \mathrm{~m}(11,780 \mathrm{ft})$, respectively. Temperatures in the reservoir section of the type well range from $135^{\circ} \mathrm{C}\left(275^{\circ} \mathrm{F}\right)$ calculated for the top of the reservoir interval at $3,408 \mathrm{~m}(11,180 \mathrm{ft})$ to $150^{\circ} \mathrm{C}\left(302^{\circ} \mathrm{F}\right)$ recorded at the total depth of $3,605 \mathrm{~m}(11,826 \mathrm{ft})$. In the test well, temperatures should range from approximately $138^{\circ} \mathrm{C}\left(280^{\circ} \mathrm{F}\right)$ at the top of the reservoir interval to $163^{\circ} \mathrm{C}\left(325^{\circ} \mathrm{F}\right)$ at the base.

As determined from mud weights, the highest pressure gradient in the type well is $14.34 \mathrm{kPa} / \mathrm{m}(0.634 \mathrm{psi} / \mathrm{ft})$, which was reached at a depth of $3,444 \mathrm{~m}(11,300 \mathrm{ft})$. Bottom-hole pressure was calculated to be $49,394 \mathrm{kPa}(7,164 \mathrm{psi})$ on the basis of that gradient. In the test well, the top of geopressure is expected to be at $3,660 \mathrm{~m}(12,000$ $\mathrm{ft})$.

Salinities computed for the type well, Union \#A-1 Thomas, were discussed in the previous section on formation and fluid properties of the Colorado Fairway. The test well is expected to have a similar salinity profile. 


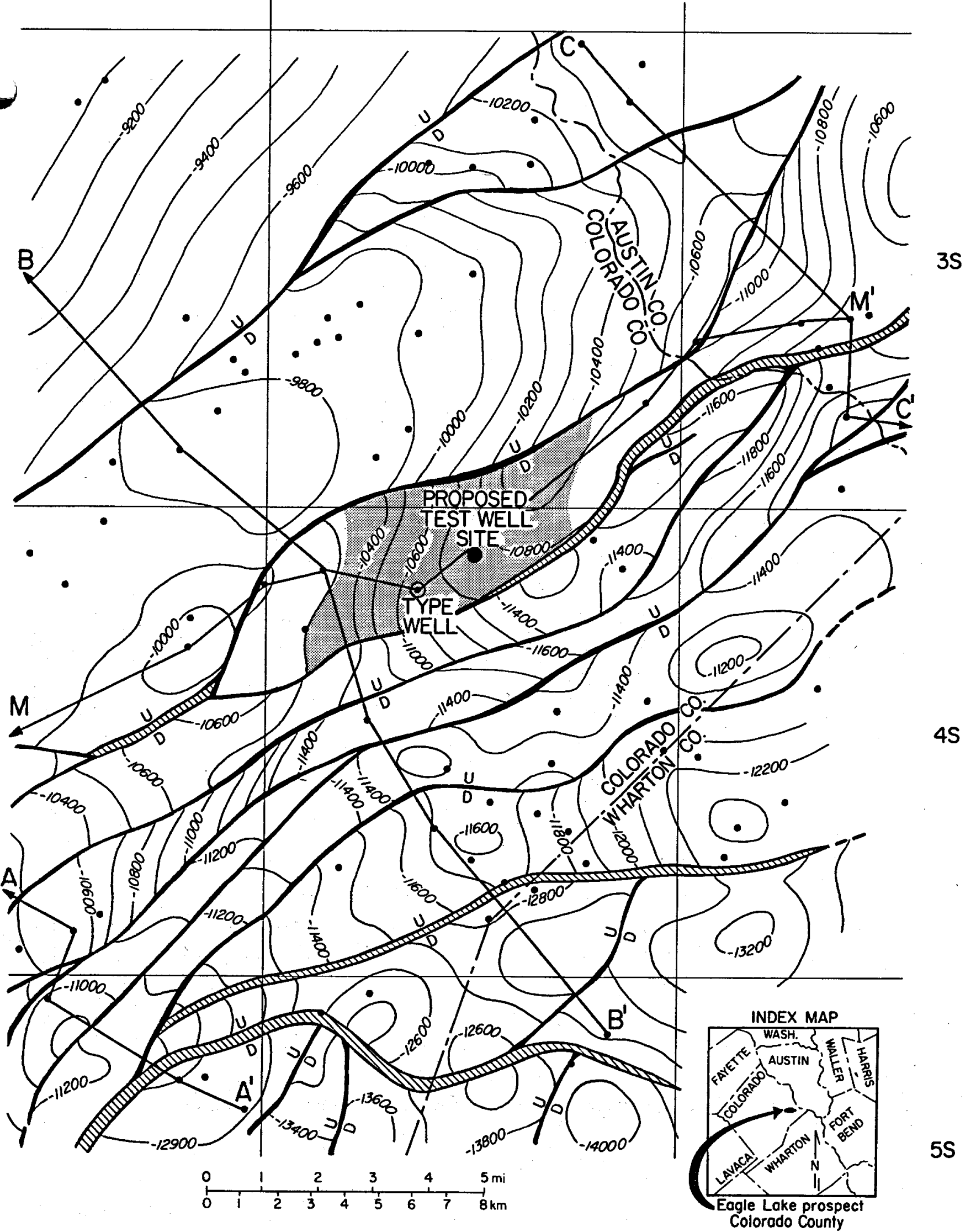

Figure 135. Eagle Lake Prospect, type-well site, and proposed test-well site, Colorado Fairway. Mapping horizon is the $\mathrm{C} 4$ marker, which approximates the top of the lower Wilcox. Contour interval is $30 \mathrm{~m}(100 \mathrm{ft})$. 


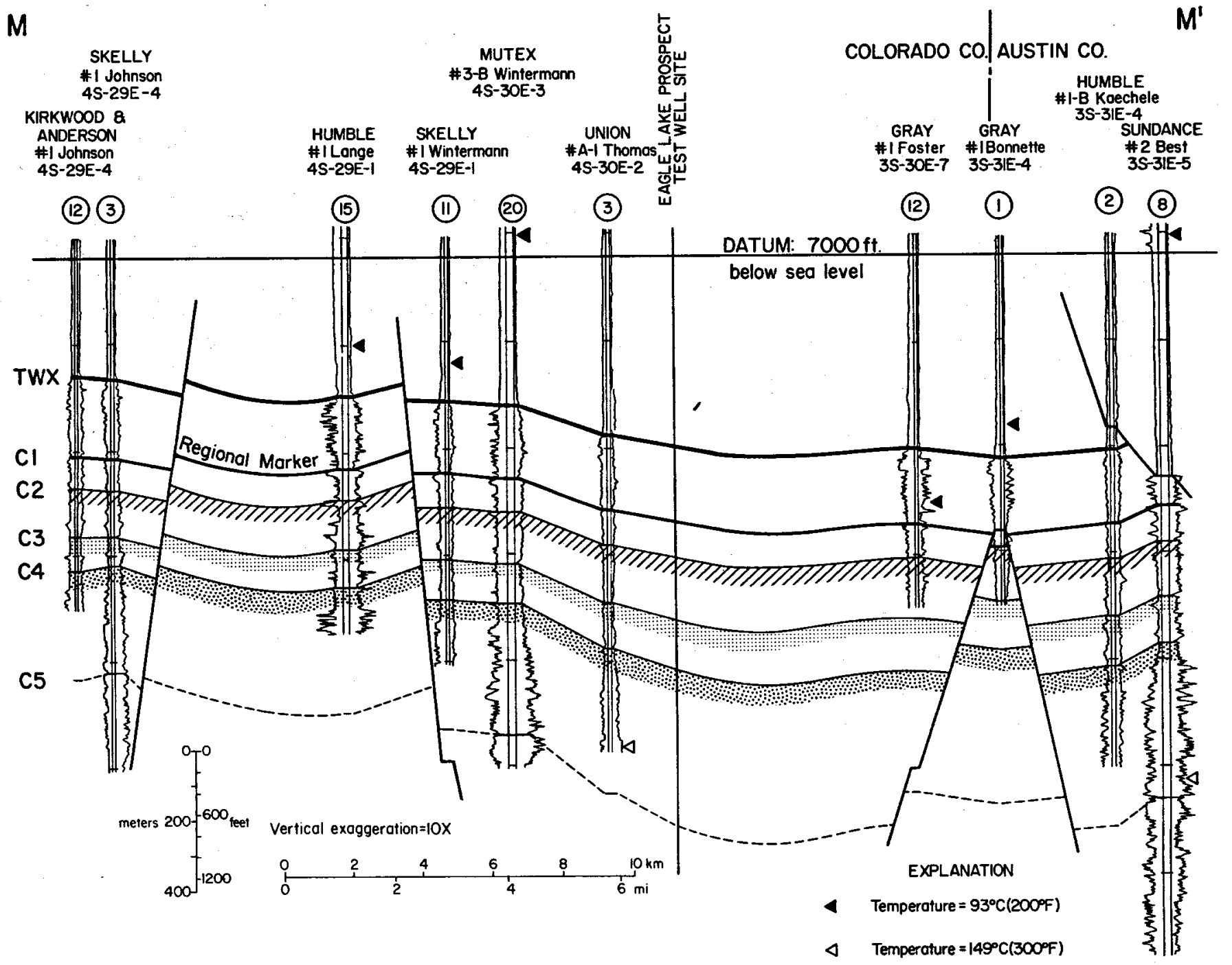

Figure 136. Structural strike section MM', Colorado Fairway. 
M
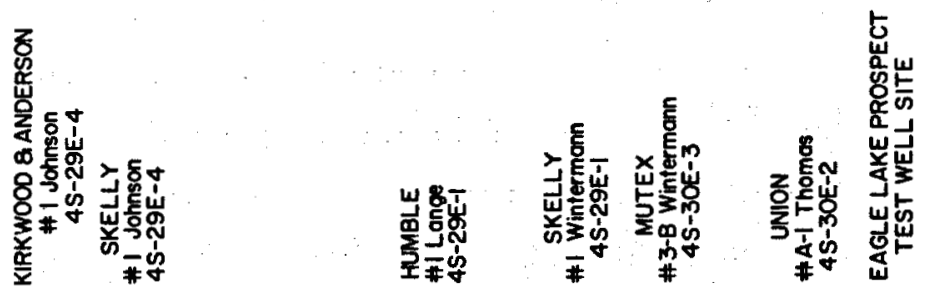

(12) (3)

(15)

(11) (20)

(3)

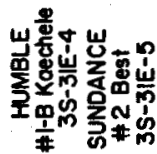

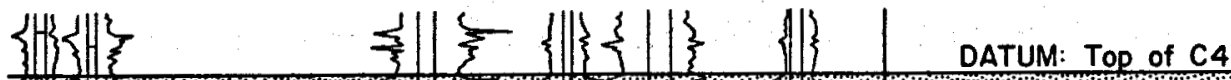

(2) ()

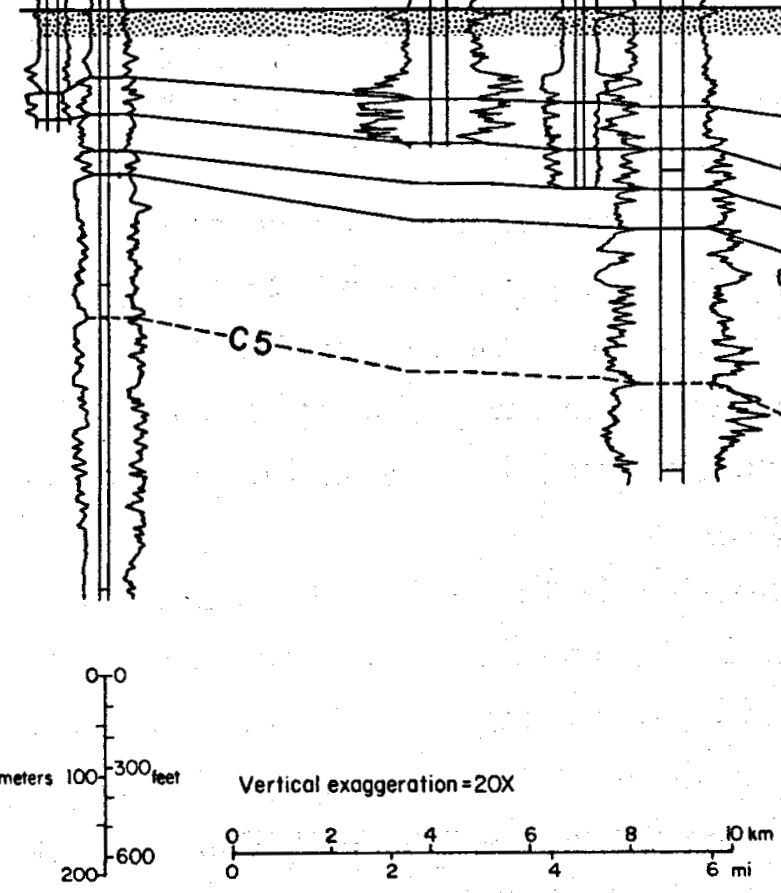

EXPLANATION

4

Temperoture $=149^{\circ} \mathrm{C}\left(300^{\circ} \mathrm{F}\right)$

A

$E$

$\mathbf{F}$
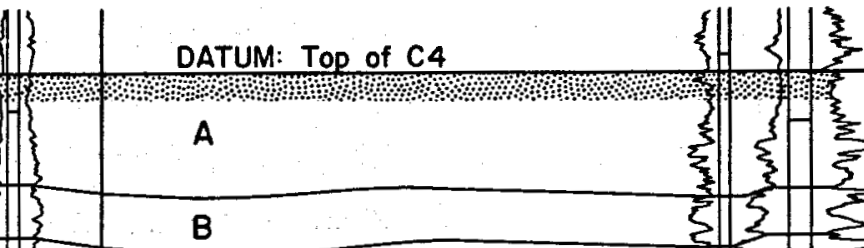

Figure 137. Stratigraphic strike section MM', Colorado Fairway. Datum is the C4 marker. The reservoir section below the $\mathrm{C} 4$ marker is correlated in detail (units $\mathrm{A}$ through F). 
The Harris Fairway contains thick geopressured sandstone units with temperatures greater than $149^{\circ} \mathrm{C}\left(300^{\circ} \mathrm{F}\right)$, but permeabilities in these units are consistently less than $1 \times 10^{-3} \mu \mathrm{m}^{2}(1 \mathrm{md})$.

The Harris Fairway, trending northeastward, extends over parts of Waller, Fort Bend, Harris, Grimes, Montgomery, Liberty, and San Jacinto Counties (fig. 138). The fairway study area is approximately $123 \mathrm{~km}(77 \mathrm{mi})$ long and $54 \mathrm{~km}(34 \mathrm{mi})$ wide. This fairway was delineated as an area of potential geopressured-geothermal reservoirs during the regional study of the Texas Gulf Coast Wilcox Group (Bebout, Gavenda, and Gregory,-1978). Selection of this area for study was made on the basis of the great thickness of massive sandstones in the lower Wilcox. Maximum net-sandstone values (more than $610 \mathrm{~m}$, or 2,000 ft) for the lower Wilcox of Texas occur within the Harris Fairway (fig. 33). Much of the lower Wilcox sandstone in the downdip parts of this area is geopressured and shows temperatures greater than $149^{\circ} \mathrm{C}\left(300^{\circ} \mathrm{F}\right)$.

The Harris study area extends farther updip than do the Colorado or De Witt study areas. The Wilcox in these updip parts of the Harris area is sandy throughout, as shown by the logs of wells farthest updip on the stratigraphic section DD' (fig. 139). Downdip, however, the Wilcox section in the Harris Fairway is similar to that in the Colorado and De Witt Fairways; the middle Wilcox section is shaly, and the upper and lower Wilcox sandy intervals are much more distinct.

The upper Wilcox is characterized by massive sandstone over the entire Harris Fairway. The H1 marker occurs near the base of this upper sandstone-rich section of the Wilcox (fig. 139) and can be correlated into other fairways. This marker is the "regional marker" shown on the regional cross sections (figs. 10 through 32) and is equivalent to $\mathrm{Cl}$ in the Colorado Fairway and D1 in the De Witt Fairway, for examples. Three other Wilcox stratigraphic markers, $\mathrm{H} 2, \mathrm{H} 3$, and $\mathrm{H} 4$, have been recognized within the Harris Fairway (fig. 139); the H3 marker, which corresponds stratigraphically to the C3 marker in the Colorado Fairway (fig. 121) was the only one of these three markers to be traced outside the Harris Fairway.

The $\mathrm{H} 4$ marker occurs at depths of 12 to $110 \mathrm{~m}$ ( 40 to $360 \mathrm{ft}$ ) below the top of the lower Wilcox shown on the regional cross sections 15 through 19 (figs. 24 through 28). Throughout most of the Harris Fairway, the lower Wilcox shows massive sandstones. As in the De Witt and Colorado Fairways, however, rapid facies changes, faults, and sparse deep well control make the lower Wilcox section difficult to 
correlate. Thus, the thick section of interest for geopressured-geothermal reservoirs could not be subdivided for more detailed study and construction of meaningful netsandstone maps. Cross sections, however, indicate areas of maximum sandstone. Lower Wilcox intervals of thick net sandstone, all or much of it geopressured and with fluid temperatures greater than $149^{\circ} \mathrm{C}\left(300^{\circ} \mathrm{F}\right)$, are shown on the Humble $\# 31$ Katy Gas Field well $\log$ on cross section $\mathrm{DD}^{\prime}$ (fig. 140) and the Texaco \#1 Mergele and Texaco \# 1 Sweeney Estate logs on section EE' (fig. 141).

The Harris Fairway is an area of salt domes and salt withdrawal basins. Parts of the middle and upper Wilcox section thin over a few of the domes. The thinning was most probably the result of lack of deposition rather than erosion. Therefore, growth of some of the domes had begun during or before Wilcox deposition, while others did not affect Wilcox structure until after deposition and burial. Unfortunately, few wells on the domes are deep enough to penetrate the lower Wilcox, thus hampering detailed study of the effect of the domes on lower Wilcox deposition.

Down-to-the-coast faults are common in the Harris Fairway, but large Wilcox growth faults are much rarer than in most of the other fairways to the southwest. The upper and middle Wilcox show no differential growth caused by fault movement except in the areas farthest downdip (southeastward). Stratigraphic section DD' (fig. 139) illustrates the gradual downdip thickening of the intervals defined by the various correlation markers. Examples of growth faults occurring in the most basinward part of the fairway are shown on the Scurlock 非 1 Meek well log on structural cross section DD' (fig. 140) and on the Superior \#1 Hightower well log on section HH' (fig. 142). Growth faults affecting the lower Wilcox within the fairway may be more numerous and of greater magnitude but are much more difficult to analyze because of the sparse deep well control.

Average depths to the top of geopressure gradients 10.5 and $15.8 \mathrm{kPa} / \mathrm{m}(0.465$ and $0.70 \mathrm{psi} / \mathrm{ft}$ ) are 2,790 and $3,520 \mathrm{~m}(9,150$ and $11,550 \mathrm{ft}$ ), respectively (fig. 143) based on bottom-hole shut-in pressure measurements for 23 wells in Harris County. Pressure gradients increased with depth to a maximum of $19.0 \mathrm{kPa} / \mathrm{m}(0.84 \mathrm{psi} / \mathrm{ft})$ at a depth of $4,070 \mathrm{~m}(13,350 \mathrm{ft})$. Top of geopressure was picked from shale resistivity plots (figs. 144 through 150) for selected wells on geological cross sections DD', EE', and $\mathrm{HH}^{\prime}$ (figs. 140 to 142 ). Wells with shale resistivities that fall on or to the right of the normal compaction curve (NCC) were not considered to be geopressured in this report (figs. 144, 146, and 148). Geopressure profiles were computed for wells with shale resistivity values that were less than normal. Wells with highly geopressured 
formations include the Humble \#W-21 Katy Gas Field, Unit \#1 (fig. 145), Texaco \#1 J. J. Sweeney Estate (fig. 147), and Superior Oil Co., \#1 T. J. Hightower (fig. 150).

Equilibrium temperatures and geothermal gradients have been calculated for an area that includes parts of Harris, Liberty, Austin, and Colorado Counties and portions of adjacent counties (fig. 151). The geothermal gradient in the upper Wilcox is about $3.8^{\circ} \mathrm{C} / 100 \mathrm{~m}\left(2 \cdot 10^{\circ} \mathrm{F} / 100 \mathrm{ft}\right)$ in the depth interval 2,530 to $4,267 \mathrm{~m}(8,300$ to $14,000 \mathrm{ft})$. The lower Wilcox from 4,267 to $5,486 \mathrm{~m}(14,000$ to $18,000 \mathrm{ft})$ has a gradient of about $2.2^{\circ} \mathrm{C} / 100 \mathrm{~m}\left(1.20^{\circ} \mathrm{F} / 100 \mathrm{ft}\right)$. Formations above the Wilcox from 0 to $3,048 \mathrm{~m}(0$ to $10,000 \mathrm{ft}$ ) have a geothermal gradient of about $2.6^{\circ} \mathrm{C} / 100 \mathrm{~m}\left(1.40^{\circ} \mathrm{F} / 100 \mathrm{ft}\right)$. A subsurface temperature of $150^{\circ} \mathrm{C}\left(302^{\circ} \mathrm{F}\right)$ occurs at $3,978 \mathrm{~m}(13,050 \mathrm{ft})$ below sea level.

Temperature versus depth plotted (fig. 152) for wells on geological cross sections DD', EE', and HH' have a distribution of data points with a geothermal gradient of $2.88^{\circ} \mathrm{C} / 100 \mathrm{~m}\left(1.58^{\circ} \mathrm{F} / 100 \mathrm{ft}\right)$ from 0 to $3,658 \mathrm{~m}(0$ to $12,000 \mathrm{ft})$. A gradient of $3.94^{\circ} \mathrm{C} / 100 \mathrm{~m}\left(2.16^{\circ} \mathrm{F} / 100 \mathrm{ft}\right)$ is found in deeper formations down to $5,335 \mathrm{~m}(17,500$ $\mathrm{ft})$. A temperature of $149^{\circ} \mathrm{C}\left(300^{\circ} \mathrm{F}\right)$ occurs at about $3,960 \mathrm{~m}(12,990 \mathrm{ft})$.

Data for 14 wells located in the Harris County Geothermal Fairway (fig. 153) show a trend of decreasing salinity from 2,316 to $3,962 \mathrm{~m}(7,600$ to $13,000 \mathrm{ft})$. Maximum salinities of $197,000 \mathrm{ppm} \mathrm{NaCl}$ occur at $2,590 \mathrm{~m}(8,500 \mathrm{ft})$ and minimum values of 11,500 to $20,000 \mathrm{ppm} \mathrm{NaCl}$ occur at depths between 3,232 and 4,400 $\mathrm{m}$ $(10,600$ and $14,450 \mathrm{ft})$. Few salinity values were calculated for shallow sandstones, but the normal trend is one of increasing salinity from 600 to about $2,500 \mathrm{~m}(2,000$ to $8,200 \mathrm{ft})$.

Available whole-core data for several wells in Harris County show that most permeabilities of sandstones in the deep subsurface are less than $5 \times 10^{-3} \mu \mathrm{m}^{2}(5 \mathrm{md})$ and many are less than $1 \times 10^{-3} \mu^{2}(1 \mathrm{md})$. Moderately good permeabilities of $1.5 \mathrm{x}$ $10^{-3}$ to $19 \times 10^{-3} \mu^{2}(1.5$ to $19 \mathrm{md})$ are found in a few thin sandstone intervals at depths exceeding $4,000 \mathrm{~m}(13,120 \mathrm{ft})$.

Porosities in these thin sandstones average about 15 percent. Sidewall cores from the same wells have measured average permeabilities and porosities of $241 \times 10^{-3}$ $\mu \mathrm{m}^{2}(241 \mathrm{md})$ and 32 percent in the depth interval 1,957 to $2,073 \mathrm{~m}(6,420$ to 6,800 ft). 




Figure 138. Location of wells and lines of section, Harris Fairway. 


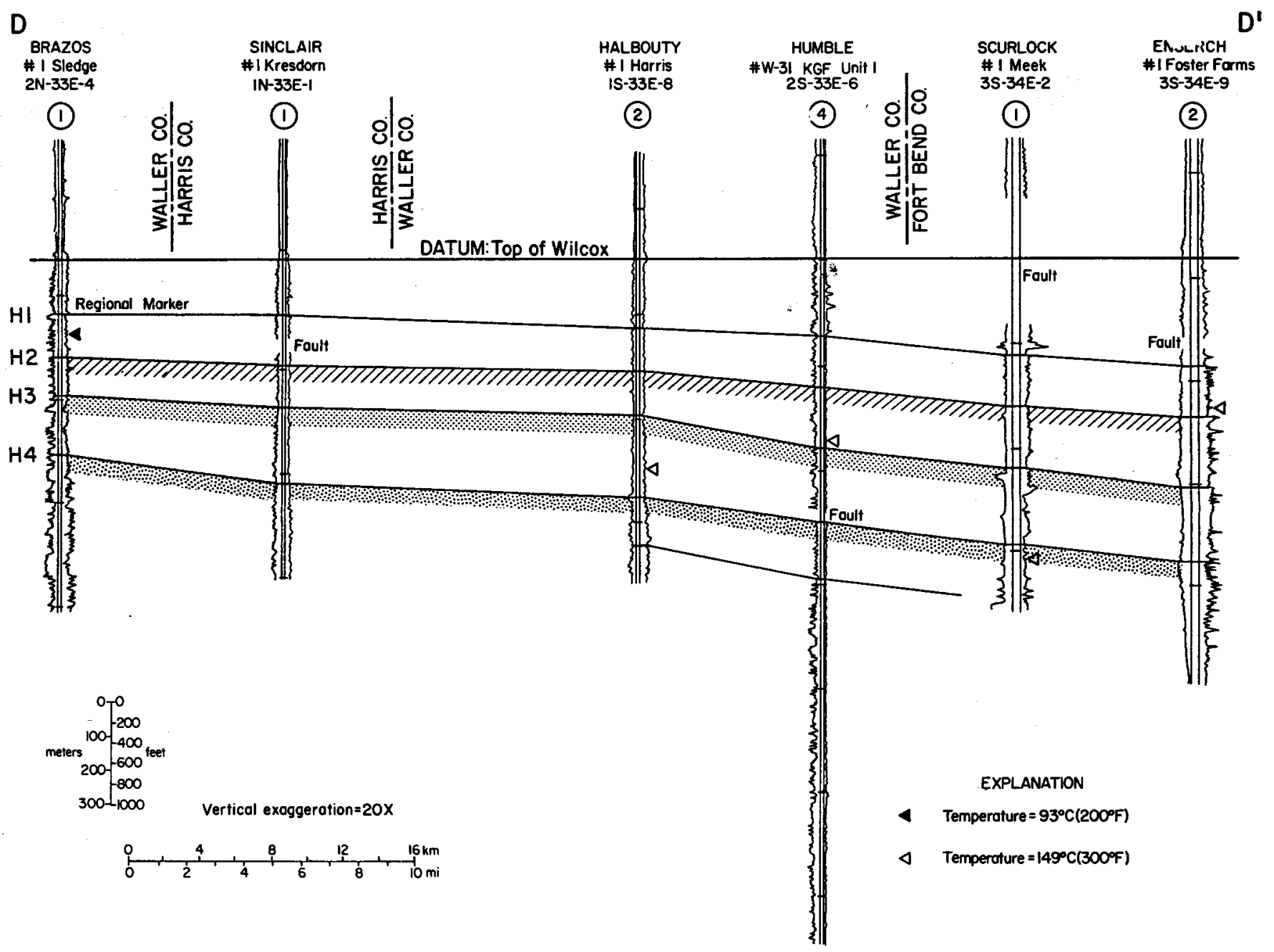

Figure 139. Stratigraphic dip section DD', Harris Fairway. 


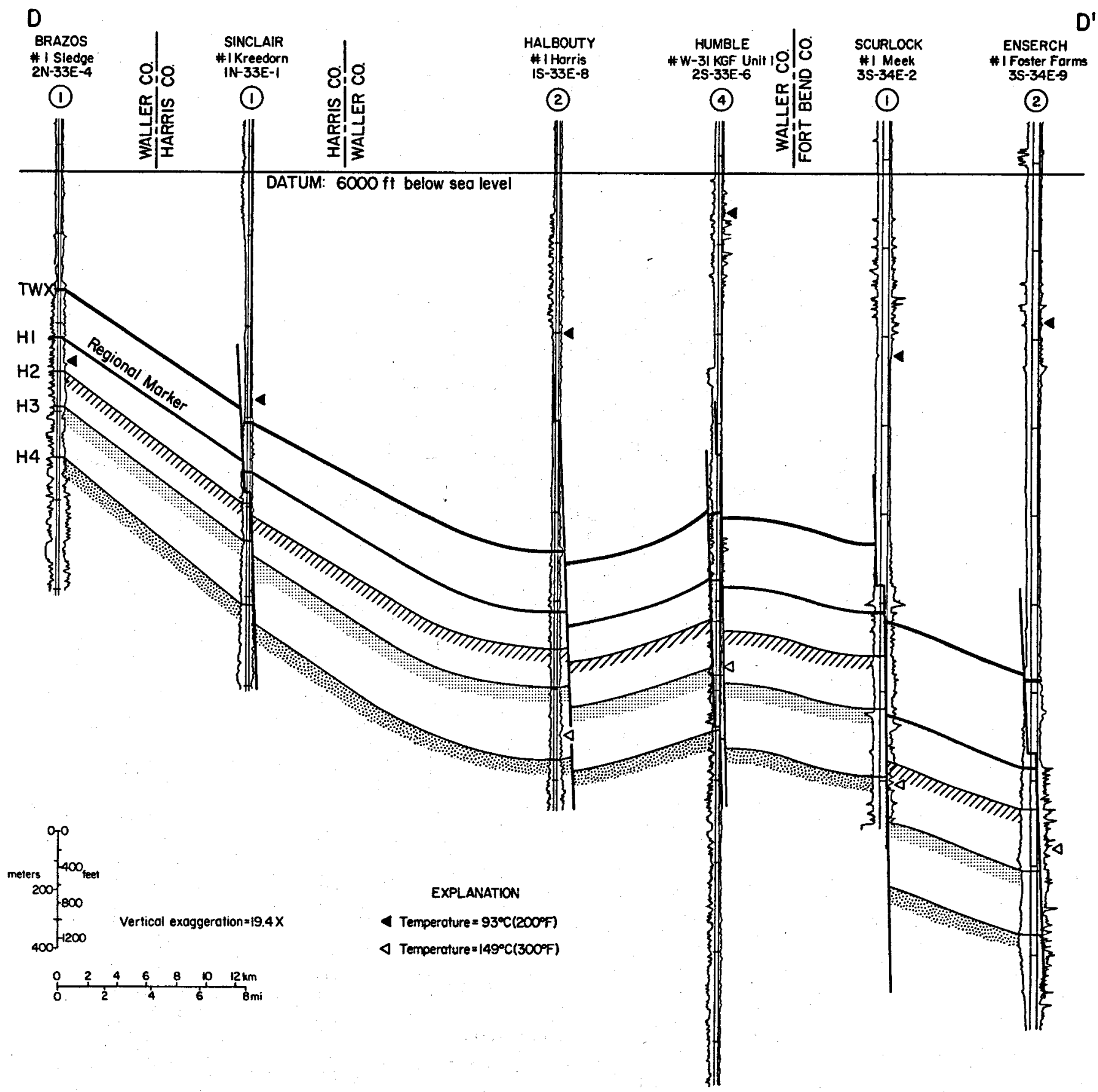

Figure 140. Structural dip section DD', Harris Fairway. 
$E$

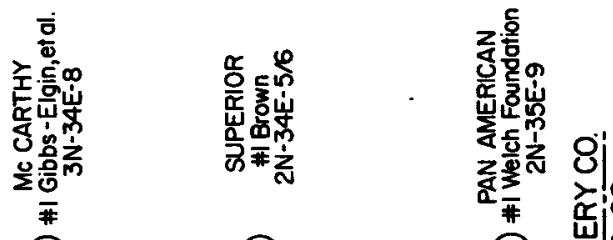

(3)

(6)

(24)

DATUM: 6000 密
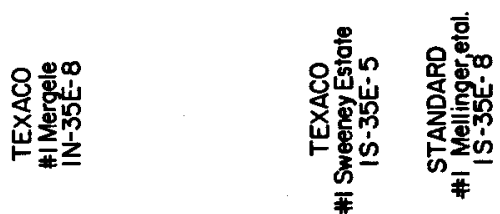

$E^{\prime}$

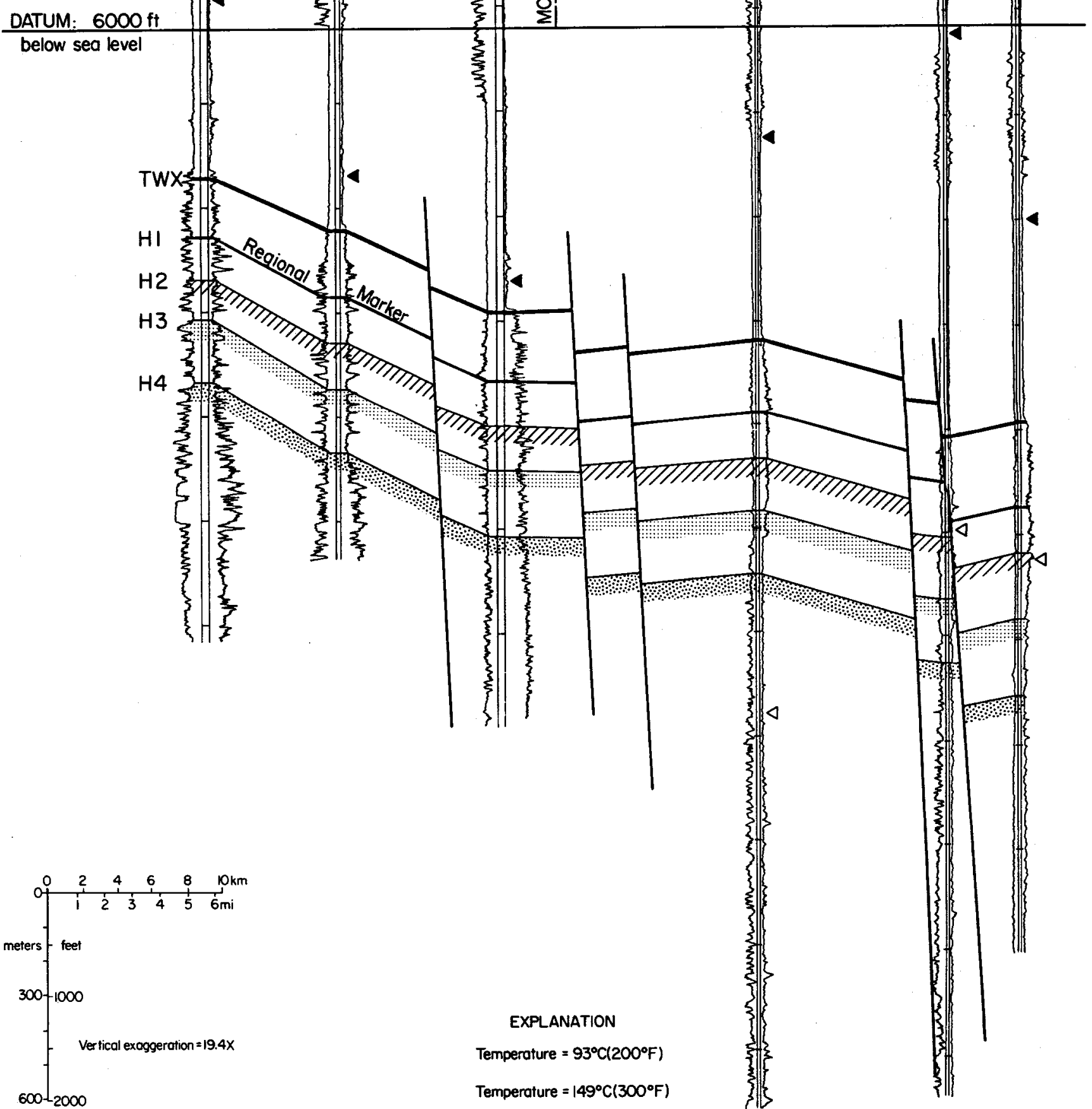

Figure 141. Structural dip section EE', Harris Fairway. 
H

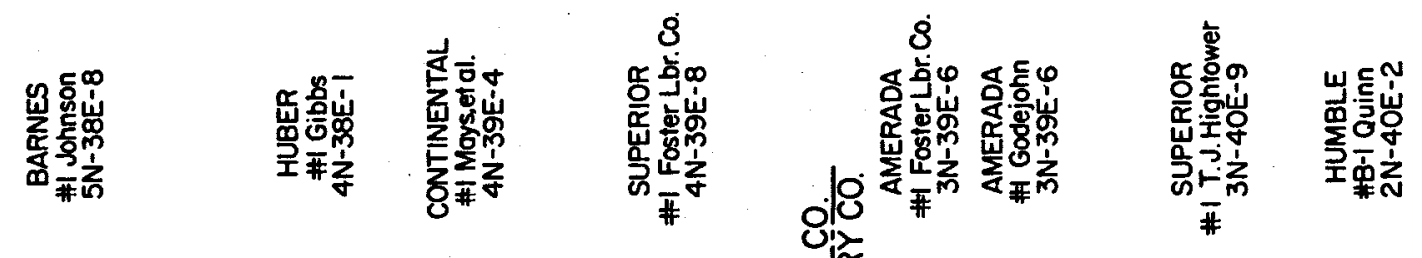

(2)

(3) (3) (8)

(10) (15)

(11) (1)

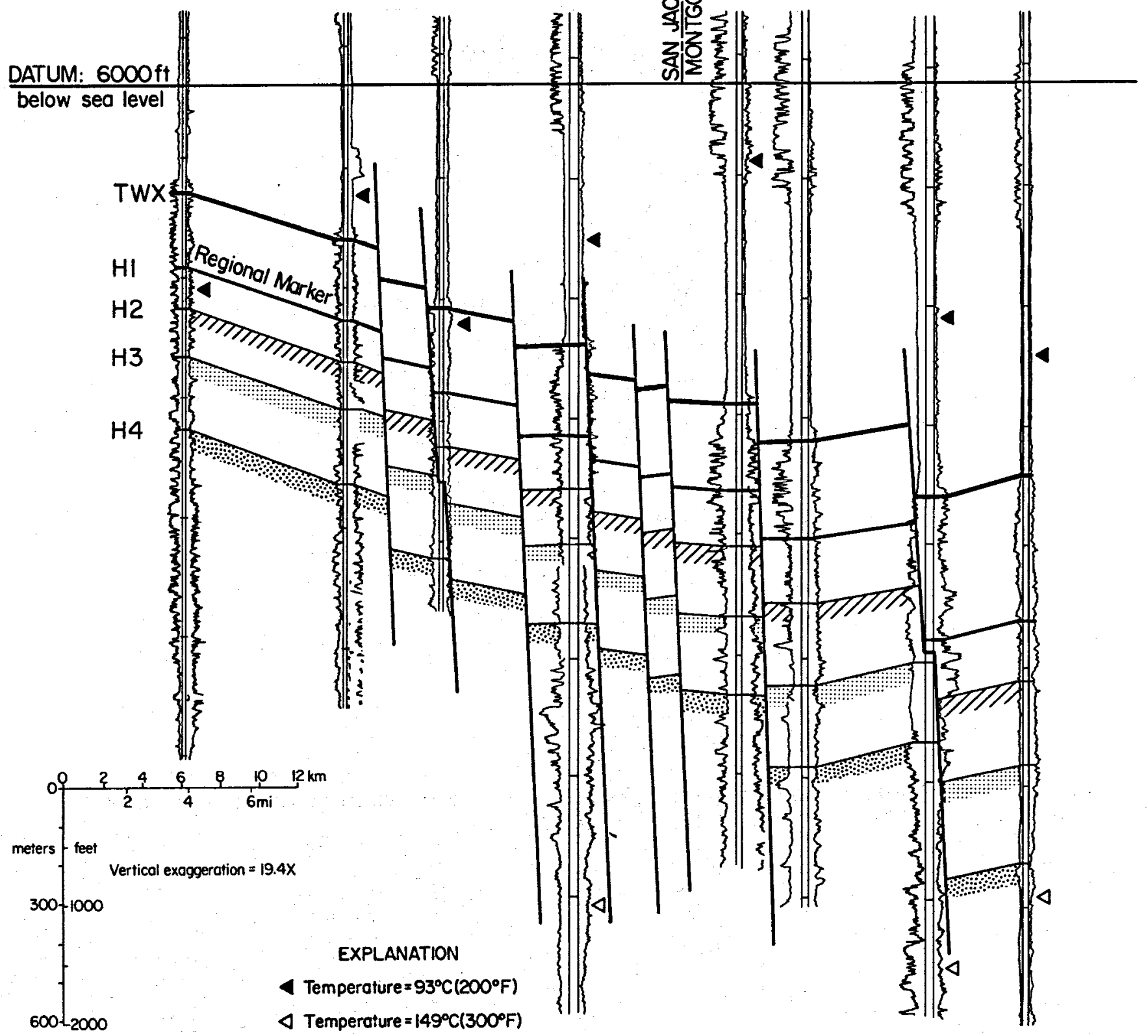

Figure 142. Structural dip section $\mathrm{HH}^{\prime}$, Harr is Fairway. 


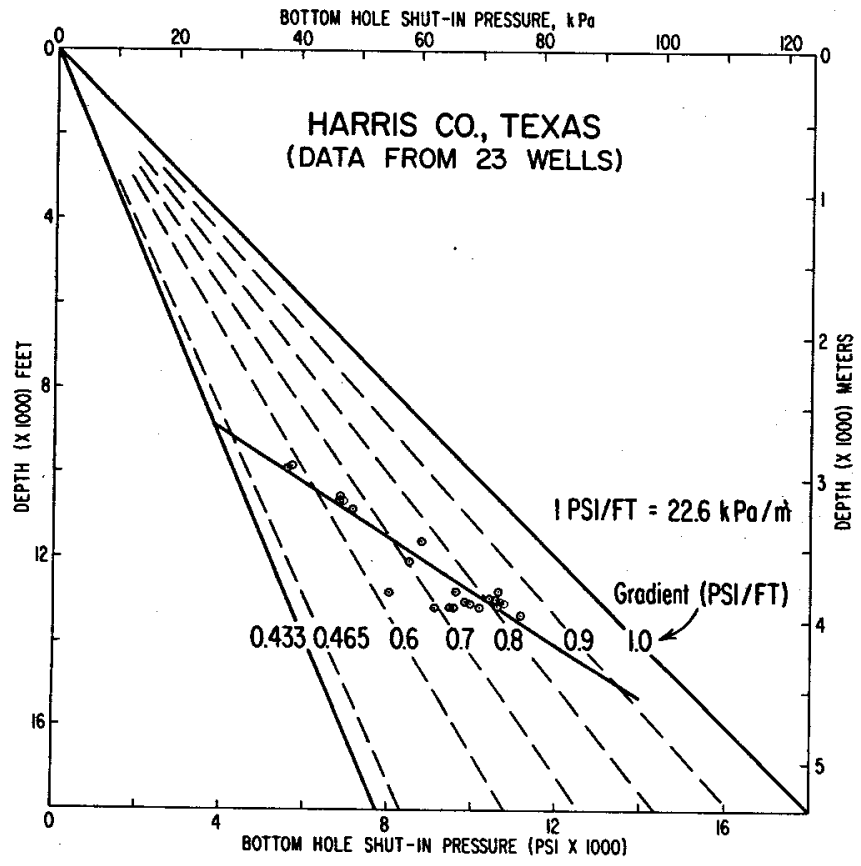

Figure 143. Bottom-hole shut-in pressures from drill stem tests as a function of depth for 23 wells located in Harris County. 


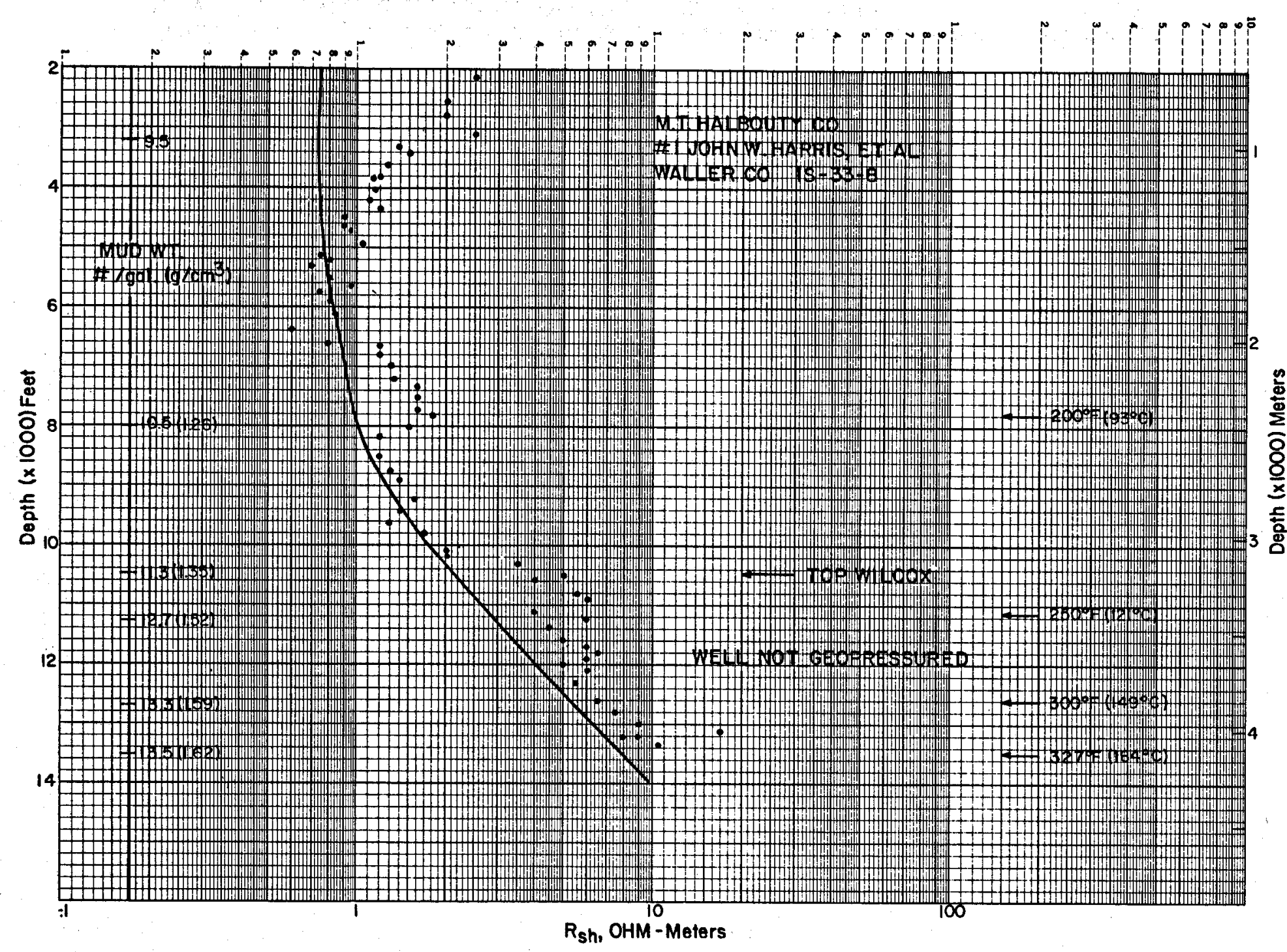

Figure 144. Shale resistivity versus depth for a nongeopressured well located on cross section DD' (fig. 139), Waller County. 


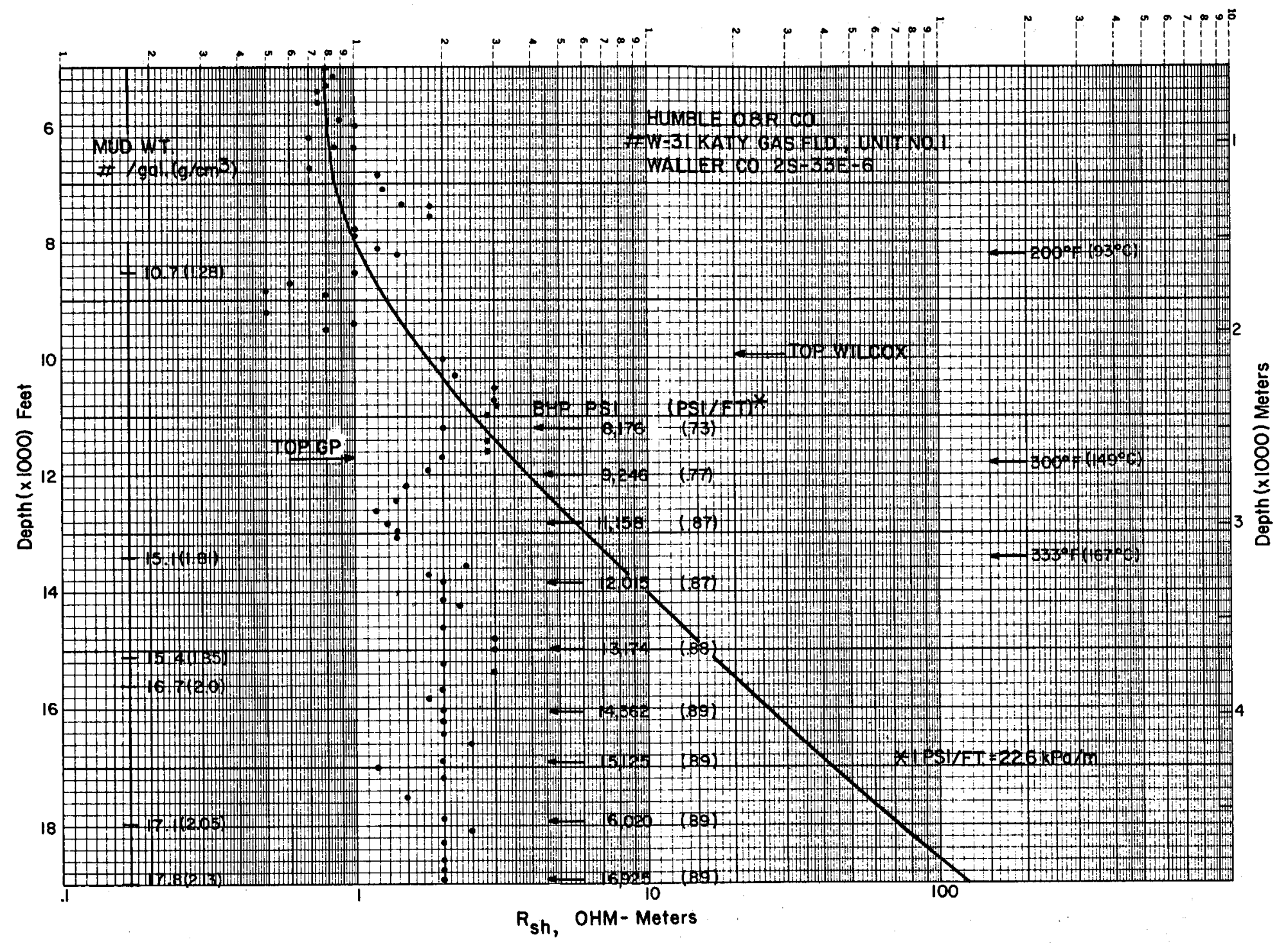

Figure 145. Top of geopressure and geopressure gradients from shale resistivity data for well located on cross section DD' (fig. 139), Waller County. 


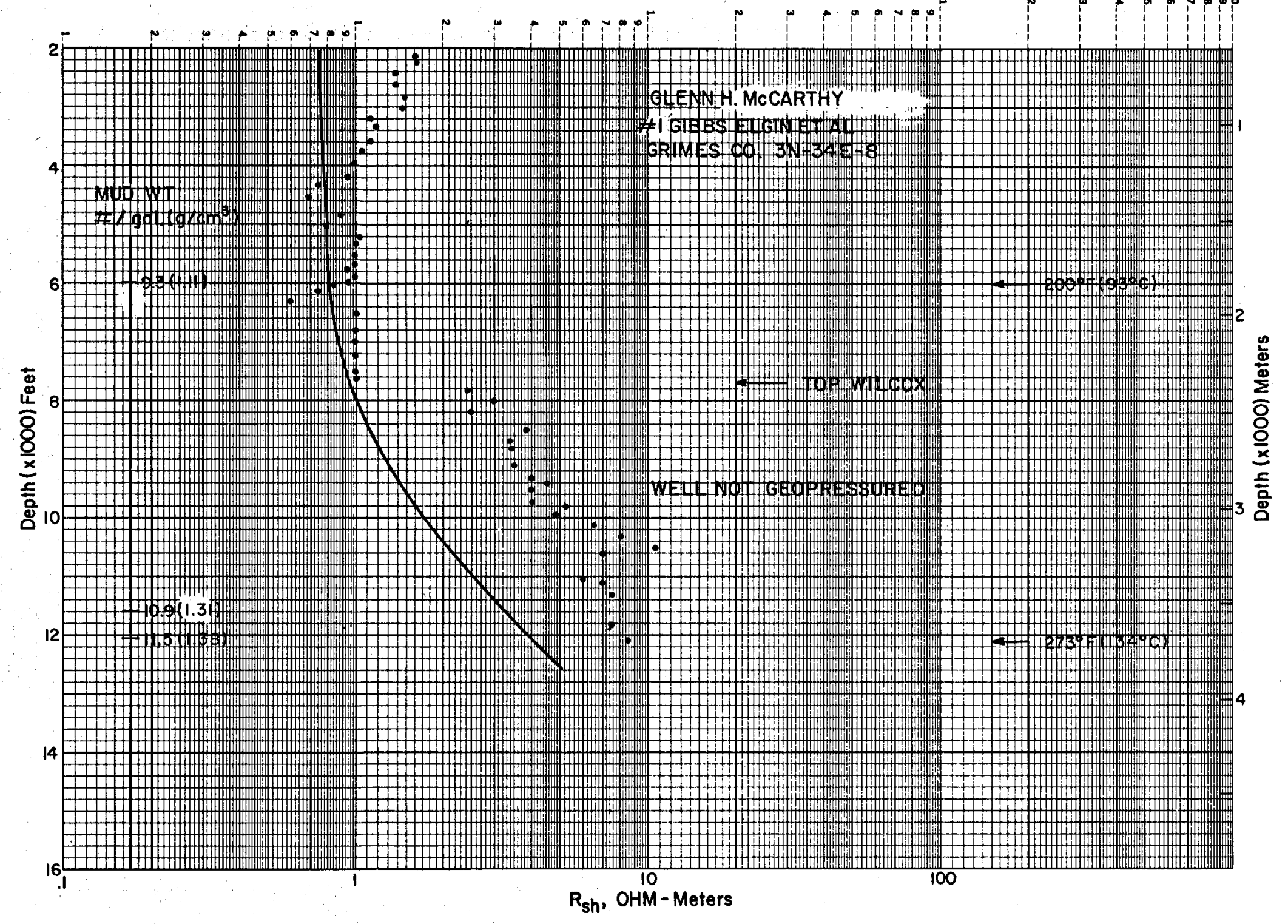

Figure 146. Shale resistivity versus depth for a nongeopressured well located on cross section EE' (fig. 141), Grimes County. 


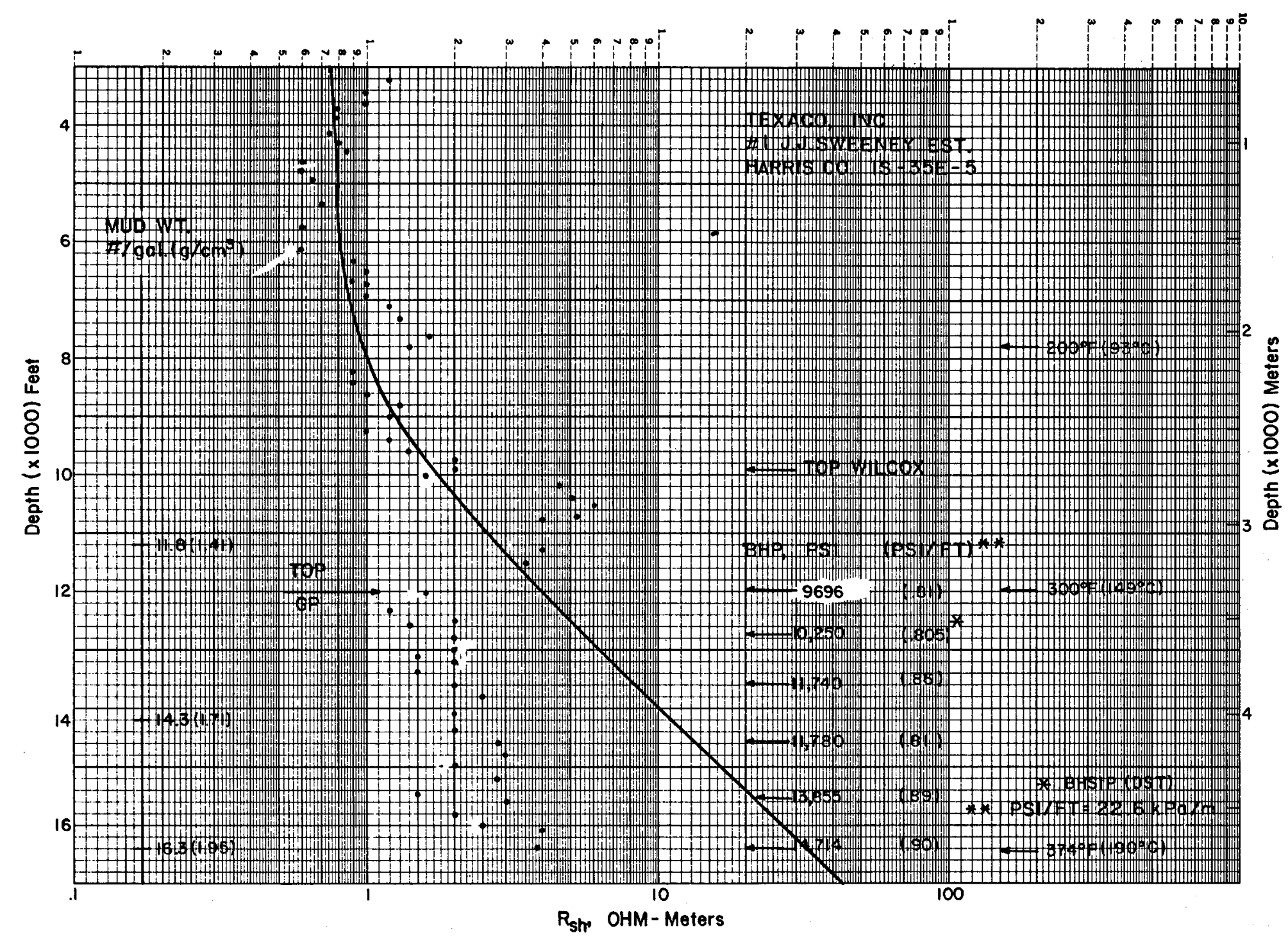

Figure 147. Top of geopressure and geopressure gradients from shale resistivity data for well located on cross section EE' (fig. 141), Harris County. 




Figure 148. Shale resistivity versus depth for a nongeopressured well located on cross section HH' (fig. 142), San Jacinto County. 


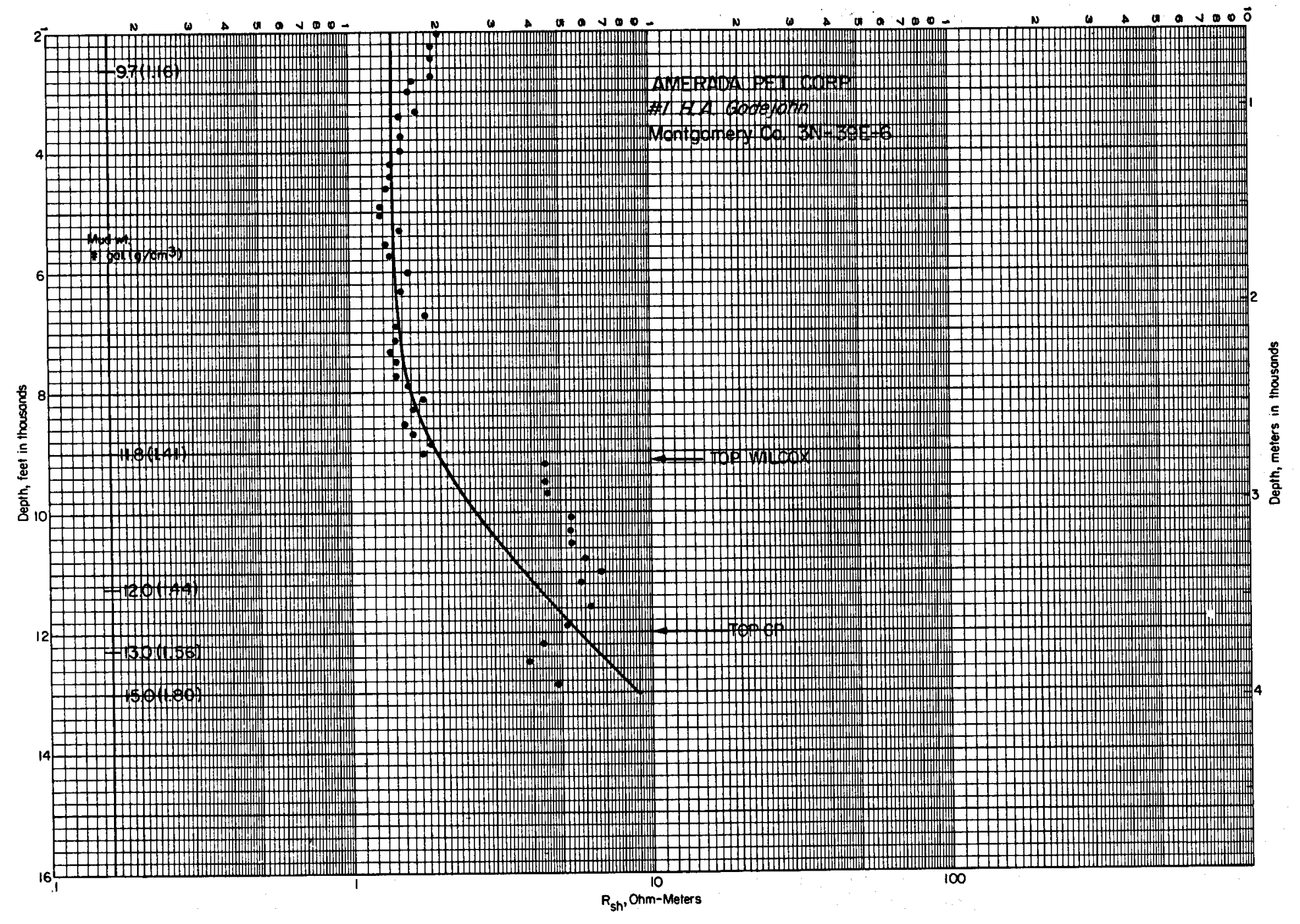

Figure 149. Shale resistivity versus depth for a well located on cross section HH' (fig. 142), Montgomery County. 


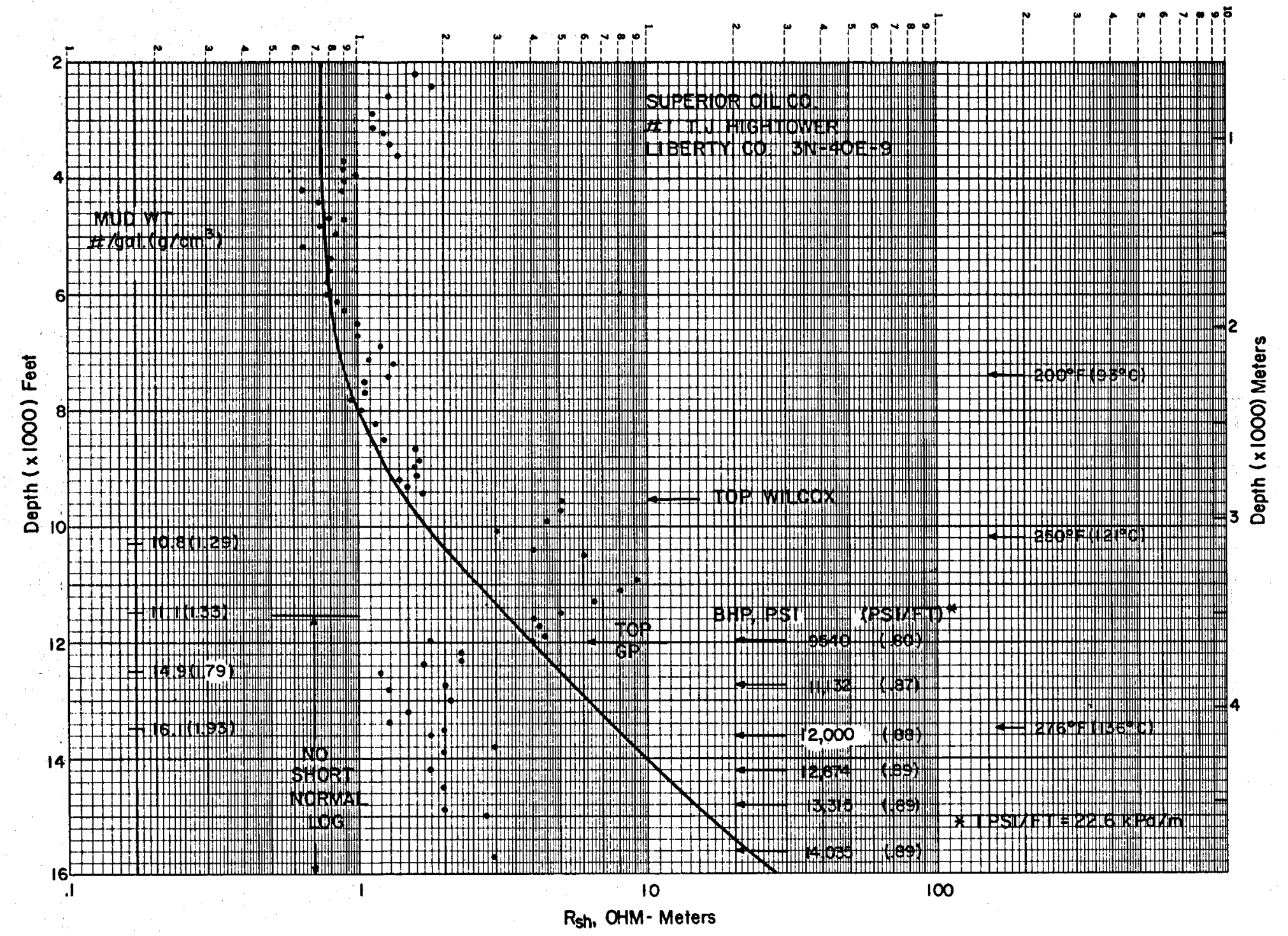

Figure 150. Top of geopressure and geopressure gradients from shale resistivity data for well located on cross section HH' (fig. 142), Liberty County. 


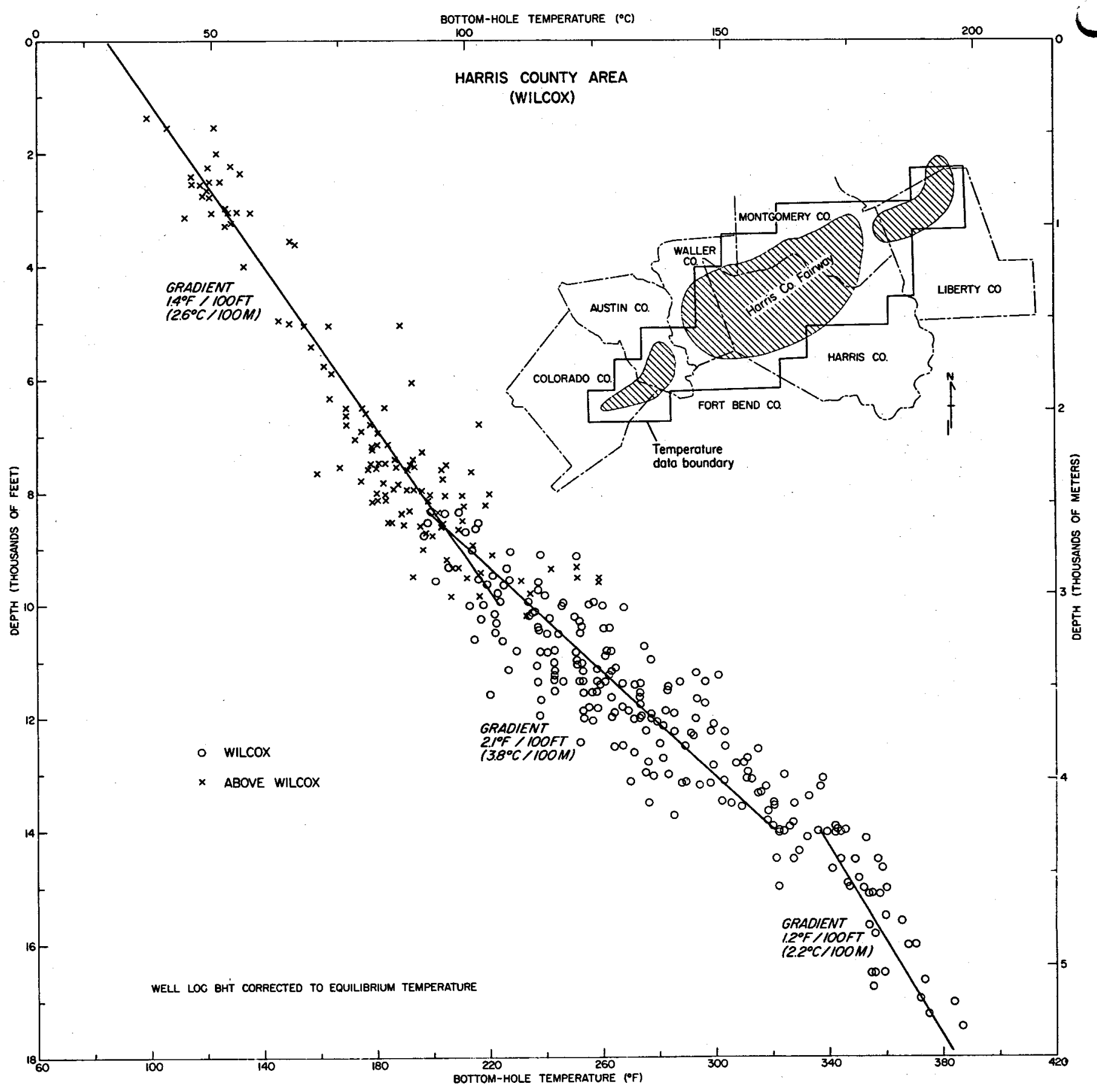

Figure 151. Temperatures and geothermal gradients for the Harris County Fairway area. 


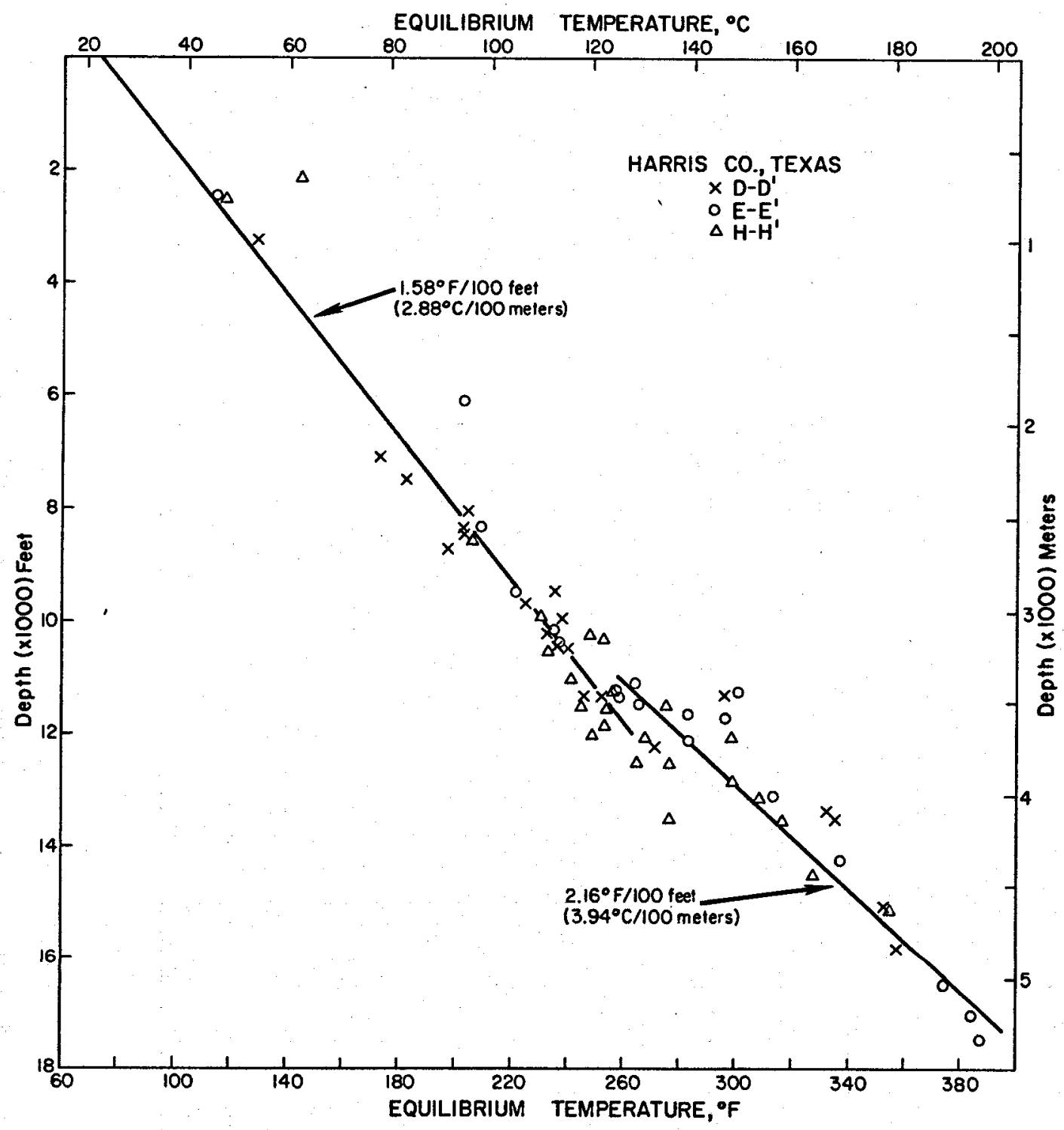

Figure 152. Temperatures and geothermal gradients for wells located on three fairway cross sections, Harris County. 


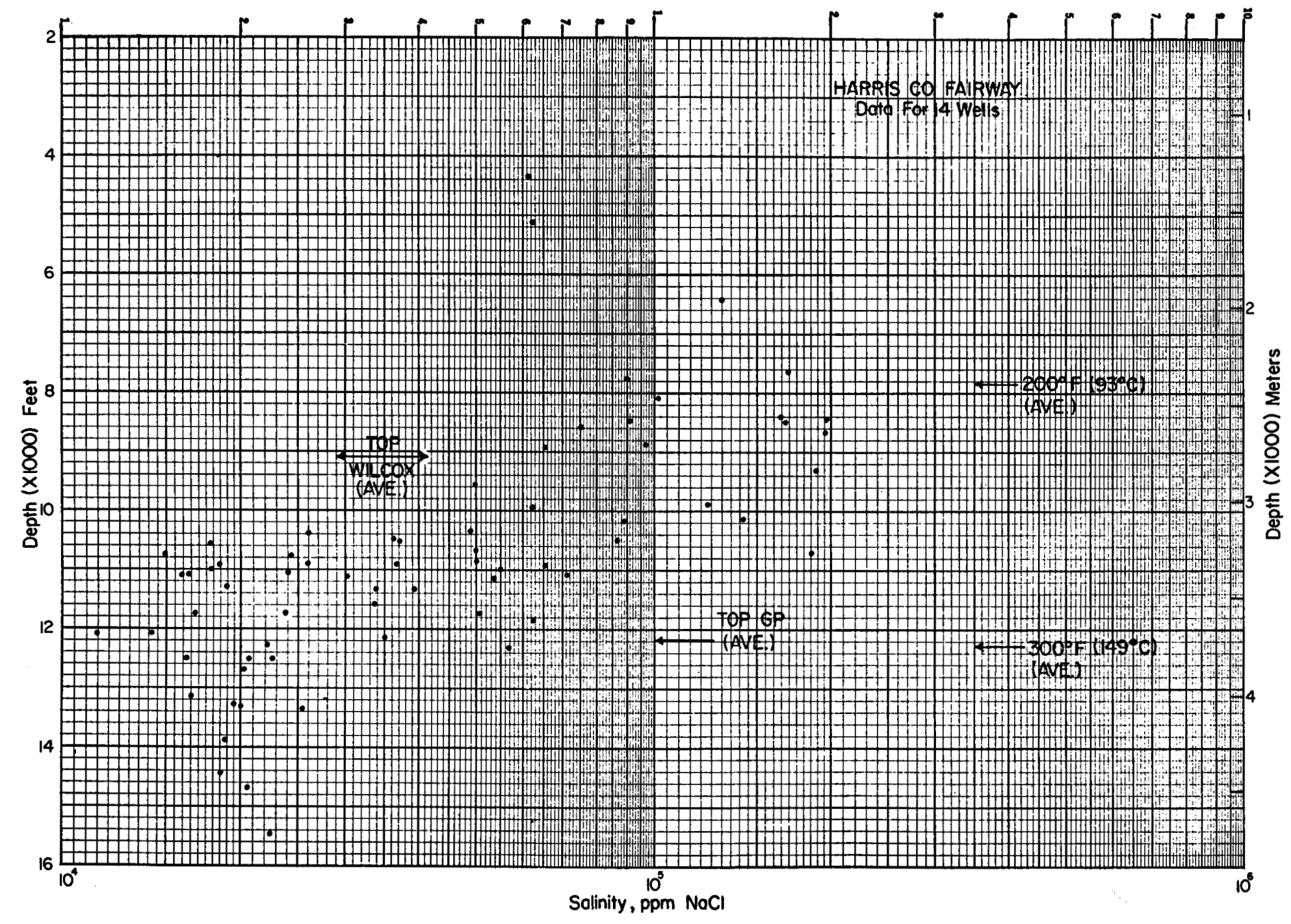

Figure 153. Salinity versus depth for 14 wells located in Harr is County Fairway area. 


\section{ACKNOWLEDGMENTS}

Funding for geopressured geothermal regional assessment and site selection studies in the Wilcox Group has been from the U.S. Department of Energy. However, many companies have contributed a variety of subsurface data essential to the success of this project. These companies are gratefully acknowledged:

\author{
Amoco Production Company \\ Atlantic Richfield Company \\ Cities Service Company \\ Exxon Company, U.S.A. \\ Gulf Oil Company, U.S.A.
}

\author{
Mobil G. C. \\ Phillips Petroleum Company \\ Shell Oil Company \\ Tenneco Oil Company \\ Texaco, Inc.
}

\section{REFERENCES}

Archie, G. E., 1942, The electrical resistivity $\log$ as an aid in determining some reservoir characteristics: American Institute of Mining Engineers Transactions, v. 146, p. 54-67.

Bateman, R. M., and Konen, C. E., 1977, The log analyst and the programmable pocket calculator: The Log Analyst, v. 18, n. 5, p. 3-11.

Bebout, D. G., Agagu, O. K., and Dorfman, M. H., 1975, Geothermal resources, Frio Formation, Middle Texas Gulf Coast: The University of Texas at Austin, Bureau of Economic Geology Geological Circular 75-8, 43 p.

Bebout, D. G., Dorfman, M. H., and Agagu, O. K., 1975, Geothermal resources--Frio Formation, South Texas: The University of Texas at Austin, Bureau of Economic Geology Geological Circular 75-1, 36 p.

Bebout, D. G., Gavenda, V. J., and Gregory, A. R., 1978, Geothermal resources, Wilcox Group, Texas Gulf Coast: The University of Texas at Austin, Bureau of Economic Geology, Report to U.S. Department of Energy, Division of Geothermal Energy, Contract No. AT-E(40-1)-4891 (EY-76-S-05-4891), 82 p. 
Bebout, D. G., Loucks, R. G., Bosch, S. C., and Dorfman, M. H., 1976, Geothermal resources-Frio Formation, Upper Texas Gulf Coast: The University of Texas at Austin, Bureau of Economic Geology Geological Circular 76-3, 47 p.

Bebout, D. G., Loucks, R. G., and Gregory, A. R., 1978, Frio sandstone reservoirs in the deep subsurface along the Texas Gulf Coast - their potential for the production of geopressured geothermal energy: The University of Texas at Austin, Bureau of Economic Geology Report of Investigations 91, 92 p.

Burst, J. F., 1959, Post-diagenetic clay mineral environmental relationships in the Gulf Coast Eocene, in A. Swineford, ed., Clays and clay minerals: Sixth National Clays and Clay Minerals Conference Proceedings, Pergamon Press, 411 p.

Burst, J. F., 1969, Diagenesis of Gulf Coast clayey sediments and its possible relation to petroleum migration: American Association of Petroleum Geologists Bulletin, v. 53, no. 1, p. 73-93.

Culbertson, J. A., 1940, Downdip Wilcox (Eocene) of Coastal Texas and Louisiana: American Association of Petroleum Geologists Bulletin, v. 24, n. 11, p. 18911922.

Deussen, A., and Owen, K. D., 1939, Correlation of surface and subsurface formations in two typical sections of the Gulf Coast of Texas: American Association of Petroleum Geologists Bulletin, v. 23, p. 1603-1634.

Dorfman, M. H., and Deller, R. W., eds., 1975, First Geopressured Geothermal Energy Conference Proceedings: The University of Texas at Austin, Center for Energy Studies, $369 \mathrm{p}$.

Dorfman, M. H., and Deller, R. W., eds., 1976, Second Geopressured Geothermal Energy Conference Proceedings: The University of Texas at Austin, Center for Energy Studies, 5 v.

Dow, W. G., 1978, Petroleum source beds on continental slopes and rises: American Association of Petroleum Geologists Bulletin, v. 62, n. 9, p. 1584-1606.

Echols, D. J., and Malkin, D. S., 1948, Wilcox (Eocene) stratigraphy, a key to production: American Association of Petroleum Geologists Bulletin, v. 32, p. 1133.

Fisher, W. L., 1969, Facies characterization of Gulf Coast Basin delta systems, with some Holocene analogues: Gulf Coast Association of Geological Societies Transactions, v. 19, p. 239-261. 
Fisher, W. L., and McGowen, J. H., 1967, Depositional systems in the Wilcox Group of Texas and their relationship to occurrence of oil and gas: Gulf Coast Association of Geological Societies Transactions, v. 17, p. 105-125.

Hardin, F. R., and Hardin, G. C., Jr., 1961, Contemporaneous normal faults of Gulf Coast and their relation to flexures: American Association of Petroleum Geologists Bulletin, v. 45, n. 2, p. 238-248.

Hargis, R. N., 1962, Stratigraphy of the Carrizo-Wilcox of a portion of South Texas and its relationship to production: Gulf Coast Association of Geological Societies Transactions, v. 12, p. 9-25.

Hottmann, C. E., and Johnson, R. K., 1965, Estimation of formation pressures from log-derived shale properties: Journal of Petroleum Technology, v. 17, p. 717723.

Hoyt, W. V., 1959, Erosional channel in the middle Wilcox near Yoakum, Lavaca County, Texas: Gulf Coast Association of Geological Societies Transactions, v. 9, p. 41-50.

Johnston, J. E., 1977, Depositional systems in the Wilcox Group and the Carrizo Formation (Eocene) of Central and South Texas and their relationship to the occurrence of lignite: The University of Texas at Austin, Master's thesis, $113 \mathrm{p}$.

Kehle, R. O., 1971, Geothermal survey of North America, 1971 Annual Progress Report: Research Committee, American Association of Petroleum Geologists (unpub.), 31 p.

Loucks, R. G., Bebout, D. G., and Galloway, W. E., 1977, Relationship of porosity formation and preservation to sandstone consolidation history--Gulf Coast lower Tertiary Frio Formation: Gulf Coast Association of Geological Societies Transactions, v. 27, p. 109-120. Reprinted in The University of Texas at Austin, Bureau of Economic Geology Geological Circular 77-5.

Loucks, R. G., 1978, Geothermal resources, Vicksburg Formation, Texas Gulf Coast: The University of Texas at Austin, Bureau of Economic Geology, Report to U.S. Department of Energy, Division of Geothermal Energy, Contract No. EY-76-S$05-4891,52 \mathrm{p}$.

Murray, G. E., 1955, Midway Stage, Sabine Stage, and Wilcox Group: American Association of Petroleum Geologists Bulletin, v. 39, p. 671-689.

Townsend, J. V., Jr., 1954, The generalized geology of the Wilcox Group of northeast Texas: Gulf Coast Association of Geological Societies Transactions, v. 4, p. 6974. 


\section{APPENDIX}

LIVE OAK FAIRWAY

Township

Range

Well No.

Well Name

$\begin{array}{lr}11 \mathrm{~S}-18 \mathrm{E}-9 & 2 \\ 11 \mathrm{~S}-18 \mathrm{E}-5 & 3 \\ 11 \mathrm{~S}-18 \mathrm{E}-8 & 5 \\ 11 \mathrm{~S}-18 \mathrm{E}-2 & 6 \\ 11 \mathrm{~S}-18 \mathrm{E}-5 / 6,8 / 7 & 7 \\ 11 \mathrm{~S}-18 \mathrm{E}-7 & 8 \\ 12 \mathrm{~S}-17 \mathrm{E}-9 & 1 \\ 12 \mathrm{~S}-17 \mathrm{E}-2 & 5 \\ 12 \mathrm{~S}-17 \mathrm{E}-2 & 6 \\ 12 \mathrm{~S}-17 \mathrm{E}-1 & 7 \\ 12 \mathrm{~S}-17 \mathrm{E}-3 & 8 \\ 12 \mathrm{~S}-17 \mathrm{E}-9 & 10 \\ 12 \mathrm{~S}-17 \mathrm{E}-4 & 12 \\ 12 \mathrm{~S}-17 \mathrm{E}-5 & 13 \\ 12 \mathrm{~S}-17 \mathrm{E}-2 & 14 \\ 12 \mathrm{~S}-17 \mathrm{E}-6 & 16 \\ 12 \mathrm{~S}-17 \mathrm{E}-6 & 17\end{array}$

12S-17E-7 18

$12 \mathrm{~S}-18 \mathrm{E}-2 / 3 \quad 10$

$12 \mathrm{~S}-18 \mathrm{E}-1$

$12 \mathrm{~S}-18 \mathrm{E}-2$

12S-19E-3 1

12S-19E-4 3

12S-19E-4 5

12S-19E-8 7

13S-16E-1 1

13S-16E-6 2

13S-16E-7 3

13S-16E-7 4

13S-16E-1 6

13S-16E-6 8

13S-16E-1 9

13S-16E-2 10

13S-16E-2 11

13S-16E-6 13

13S-16E-6 14

13S-16E-6 15

13S-16E-6 16

13S-16E-6 17
Cox \& Haring \# 1 Copeland

Union 非 Spielhagen

Pennzoil \#79 Ray

Sohio, et al. 非 1 Nichols Est.

Pennzoil \#10 Ray

Union 非 Ray

Northern Pump \& Hunt \#A-1 Hall

Forest 非 1 "B-C" Borroum

Southland \#1 Barber, et al.

Stanolind 非 1 Atkinson

Shell \# 1 Gordon

Dyco \# 1 Ballard

Texas Oil \& Gas \#A-1 Knight

Texas Oil \& Gas 非 1 Rodriguez Gas Unit

Carrl Oil, et al. 非 1 Copeland

Clover 非 1 South Texas Children's Home

Arkansas Fuel Oil, R. D. Goodrich, Harkins \& Co., and The Texas Co. 非 1 Booth

Gasoline Production Division-Zachry \#A-1 Bast

Frankfort (Texas Pacific) \#10 Walton

Texas Oil and Gas \#A-1 McKinney

Texas Pacific (Rowan \& Tong) 非9 Freeland MPS \#1 McKinney

Hewit, et al. \#1 Weiss

Miller \# 1 Farish

Coastal States \# 1 Farish

Sinclair \# 3 Dilworth

Newman Bros. 非 1 Edwards, et al.

Jones, Coates, \& Kirkwood \#1 Dunn

National Exploration 非 1 McKinney et al.

Hanson \& MacDonald \# 1 Maguglin

Blanco \# 1 Gillette

Texas Oil \& Gas \# 1 Maguglin

Venus \# 1 Goebel

Service Contracting \& Longhorn \#1 Goebel

Ryan, Mays \& Burke \#1 Gillett

Stanolind 非 1 Henderson-Coquat

Davis \#1 Dunn

The Texas Co. 非 1 Cochran

Abercrombie, Henshaw, \& Smith \#1 Dunn 
Township

Range

13S-16E-8

13S-17E-1

13S-17E-1

13S-17E-6

13S-17E-6

13S-17E-6

13S-17E-5/6, 8/7

13S-17E-7

13S-17E-8

13S-17E-8

13S-17E-9

13S-17E-9

13S-17E-2

13S-17E-1

13S-17E-3

13S-17E-2

13S-17E-2

13S-18E-4

13S-18E-4

13S-18E-8

13S-18E-4

14S-14E-4

14S-14E-6

14S-14E-9

14S-14E-1

14S-14E-6

14S-14E-6

14S-14E-8

14S-14E-9

14S-14E-9

14S-14E-8

14S-14E-5

14S-15E-6

14S-15E-6

14S-15E-6

14S-15E-6

14S-15E-8

14S-15E-8

14S-15E-7

14S-15E-8

14S-15E-8

14S-15E-9

14S-15E-9

14S-15E-2

14S-15E-2

14S-15E-3

14S-15E-3
Well No.
Well Name

Coastal States \#1 Morrison

Hughes \& Hughes \#1 MacDon-Holzmark

Hughes \& Hughes \# 1 Pouloit " $A$ "

Carl \#1 Gillett

Carl \#1 Turnbow

Dow Chemical (Southland) \# 1 McCollem

North Central, Greenbrier 66, Hanson \#\# 1 Bomar

Coastal States \#1 McCord

Argo 非 1 Huegler

Colorado Oil \& Gas \#1 Choate

Quintana \#1 Vickers

Atlantic \#1 Coward

Hamon \# 1 Ragsdale

Viking de Lange $\# 1$ Williams

Warren $\mid 1$ Dove

Bright and Schiff \#1 Schoolfield

Stanolind \#1 McCollum

White Shield 非 1 Martin

Tidewater \#1 Taylor

Tamarack 俳 1 Humberson

Halbouty 非 1 Gillett, et al.

Texam \#1 1 Hayes-Ezzell

Magnolia (Troporo) \#1 1 Means

Jones \#1 Shiner

Kilroy of Texas \#1 Herring

Tenneco \#1 Stephens

Scoggins \& Troporo 非 1 Schmid

Magnolia \#1 Jones

Jones 非C-2 Ezzell

Jones \#C-4 Ezzell

Meeker 非 1 Lebman

Magnolia \#1 Block 86

Humble \#1 Coker

Mosbachèr (Hughes \& Hughes) 非 1 Kendall

Hanson \# 1 Prosen, et al.

Mosbacher \#1 Garza Unit 1

Continental \#2 Burns

Atlantic \#8 Lyne

Getty 非 1 Christenson

La Gloria, et al. \#1 1 Bush

Kilroy \& Southland 非 1 Bierwirth, et al.

Atlantic-Richfield \#12 Lyne

Atlantic 非 Lyne

Jones \#1 West Est.

Texas Eastern \#1 Schreiner

Argo \#1 Schreiner

Kilroy of Tex. \#A-1 Herring 
LIVE OAK

Township

Range

$14 \mathrm{~S}-15 \mathrm{E}-3 / 4$

$14 \mathrm{~S}-15 \mathrm{E}-3$

14S-15E-9

$14 \mathrm{~S}-15 \mathrm{E}-9$

14S-15E-9

14S-15E-9

14S-15E-8

14S-16E-1

14S-16E-3

14S-16E-4

14S-16E-6

14S-16E-8

14S-16E-8

14S-16E-8

14S-16E-9

14S-16E-9

14S-16E-4

$14 \mathrm{~S}-16 \mathrm{E}-4$

14S-16E-4

15S-14E-1

$15 \mathrm{~S}-14 \mathrm{E}-1$

15S-14E-5

15S-14E-6

15S-14E-6

15S-14E-7

15S-14E-7

15S-14E-7

15S-14E-7

15S-14E-8

15S-14E-8

15S-15E-2

15S-15E-2

15S-15E-2

15S-15E-2

15S-15E-2

15S-15E-2

15S-15E-3

15S-15E-3

15S-15E-3

15S-15E-3

15S-15E-3

15S-15E-4

15S-15E-4

15S-15E-4

15S-15E-4

15S-15E-4

15S-15E-5

15S-15E-6
Well No.

22

23

24

25

26

27

28

1

3

4

5

8

9

10

11

12

13

17

18

1

3

4

5

6

7

8

9

10

11

12

1

2

4

5

6

7

10

11

12

13

14

15

16

17

19

20

22

23
Well Name

Interamerican Funds 非 2 Herring

Venus 非 1 Schreiner

Argo, et al. 非 1 Houdman

Warren 非 1 Whitley-Johnson

Atlantic \#11 Lyne

Mesa \#1 Johnson

Gulf Coast (L. M. Fischer)

\#1 Korczinsky-Wojtasczyk

Cherryville \#1 Williams

Gulf 非 1 Lee

Pan American \#B-1 West

Brown 非 1 Hayes

Atlantic \#1 1 Riser

Pan American \#1 1 Randall

Union of California \#1 Riser

Abercrombie \#1 West \& Perkins

Patrick \# 1 Abbey

Hanson \& Hurt \#1 Perkins

Hughes \& Hughes 非 Kendall

American Petrofina 1 I Perkins

Davis \#2 Lyne

El Chorro \& Lawley \#1 Paul, et al.

Atlantic 非 1 Morr is

Davis $\mathbb{1} 1$ Sanger Heirs

Atlantic-Richfield \#1 El Paso

Continental 非 4 Somerset

Continental 非 Somerset

Coastal States \& Zoch, et al. \# 1 Lehmberg

Southland 非 1 El Paso

Argo \#1 Baker

Rutherford 非-A Baker, et al.

Coastal States \& King \#2-A Lennox

Atlantic 非 1 Burns

Pace 非 1 Burns

Continental \#A-1 Burns

Cox 非 1 Sparkman

Hanson \& Hurt \#1 Sparkman

Hanson 非 1 National Bank of Commerce

Austral \# I Lyne

Standard Oil of Texas 非 1 Lyne, et al.

Midwest 非 1 Lyne

S.R.G. \#1 Lyne

Atlantic 非 2 Lyne

Katz \#1-B Slick

Sands 非 1 Dolan

Cherryville \#1 Lyne

Coastal States 非1.Ferrell

Tidewater \# 1 Burns

Huber $\# 1$ Tullis 
Township

Range

15S-15E-6

15S-15E-6

15S-15E-6

15S-15E-8

15S-15E-8

15S-15E-9

15S-15E-9

15S-15E-9

15S-15E-9

15S-15E-9

15S-16E-2

15S-16E-3

15S-16E-4

15S-16E-4

15S-16E-8

16S-14E-1

$16 \mathrm{~S}-14 \mathrm{E}-3$

$16 \mathrm{~S}-14 \mathrm{E}-3$

16S-14E-4

16S-14E-6

16S-14E-9

16S-15E-3
Well No.

24

25

26

27

28

29

30

31

32

33

1

2

3

4

5

1

3

4

5

6

7

2
Well Name

Tidewater 非 1 Tullis

Cherryville \#1 Tullis

Cities Service 非 1 Bailey "C"

Tenneco \#1 Jones Gas Unit

Placid \#1 Patteson

Cities Service \#1 1 Hendrick "B"

Hamill \# 1 McClure

Continental 非 3 Somerset

Katz 非-1 Slick

Coastal States 非 1 Slick

Lone Star \#1 Watson

Hanson \& McCormick \# 1 Johnson

Tidewater \#1-A Hall Est.=A

Highland 非 1 Crocker

Austral \#1 Hinnant "A"

Skelly \#1 "A" Weil

Atlantic-Richfield \#4 Baker

Argo \#1 de Arman

Argo 非 2 de Arman

Humble \#1 Brookshire

Austral 非 1 Baker

Hamon 非 1 Hefner 
Township

Range

14S-13E-7

15S-13E-1

15S-13E-3

$15 \mathrm{~S}-13 \mathrm{E}-7$

15S-13E-2

$15 \mathrm{~S}-13 \mathrm{E}-5$

15S-13E-5

$15 \mathrm{~S}-13 \mathrm{E}-5 / 8$

15S-13E-8

$16 \mathrm{~S}-12 \mathrm{E}-1$

$16 \mathrm{~S}-12 \mathrm{E}-9$

$16 \mathrm{~S}-12 \mathrm{E}-4$

$16 \mathrm{~S}-12 \mathrm{E}-8$

$16 \mathrm{~S}-12 \mathrm{E}-8$

$16 \mathrm{~S}-12 \mathrm{E}-1$

$16 \mathrm{~S}-12 \mathrm{E}-6$

$16 \mathrm{~S}-13 \mathrm{E}-3$

$16 \mathrm{~S}-13 \mathrm{E}-4$

$16 \mathrm{~S}-13 \mathrm{E}-4$

$16 \mathrm{~S}-13 \mathrm{E}-6$

$16 \mathrm{~S}-13 \mathrm{E}-6$

$16 \mathrm{~S}-13 \mathrm{E}-6$

$16 \mathrm{~S}-13 \mathrm{E}-6$

16S-13E-7

$16 \mathrm{~S}-13 \mathrm{E}-7$

$16 \mathrm{~S}-13 \mathrm{E}-8$

$16 \mathrm{~S}-13 \mathrm{E}-9$

$16 \mathrm{~S}-13 \mathrm{E}-6$

$16 \mathrm{~S}-13 \mathrm{E}-2$

$16 \mathrm{~S}-13 \mathrm{E}-1$

17S-11E-7

17S-11E-7

17S-11E-9

17S-11E-6

17S-11E-7

17S-12E-1

17S-12E-1

$17 \mathrm{~S}-12 \mathrm{E}-5$

$17 \mathrm{~S}-12 \mathrm{E}-5$

17S-12E-6

17S-12E- 1

17S-12E-1
Well No.
Well Name

Archer 非 1 Wheeler

Delange \& Neathery 非B-1 Brown

Davenport \#1-A Dolph

Argo \#V-1 Edrington

Pace \& Vreeland \# 1 La Jolla

Southland, Delange \& Ellis \# 1 Caron

Olson \#1 Whitfield

The Texas Company 非 1 Rhode

Argo \#R-1 Edrington Est.

Cox 非 1 Atkinson

Atlantic 非 1 Hagist Ranch

Hawkins \& Ranger \# 1 Hagist Ranch

Marion 非 1 Welder Heirs

Humble \#26 Dowdy Fee

Atlantic 非 1 Atkinson

Rutherford 非 1 Pursch

Argo 非 1 Roos

Harkins 非1-112 Murphy Estate

Coastal States \# 1 Ragsdale

Humble \# 1 Yeager

Sun Oil-DX Division \# 4 Penn

Sunray 非 1 American National Insurance Co.

Seaboard of Delaware \#1 Lowe

Siegfried 非 1 Lowe

Petro-Lewis 非 1 Bindewald

Mobil 非 1 Labbe Ranch

Harkins \& Humble \# 1 Ragsdale

The Texas Co. \#2 Gouger Gas Unit \# 3

Argo \#Q-1 Edrington

Sunray 非 1 Penn

Trans Texas 非 1 Hahl-Burch

Mavin \# 1 Hahl-Wiederkehr

Magnolia 非 D.C.R.C.

Horizon \#1 Lundell

Fair \& Woodward 非 1 Luptack

Argo \& Haring 非 1 Gorman

Texaco \# 1 Marshall

Humble \#B-1 Welder Heirs

Ramada 非 1-B Welder Heirs

Ramada, et al. \#1 Welder Heirs

Atlantic-Richfield 非 1 Arco, et al. Humble Fee

Atlantic-Richfield \#B-7 Welder 


\section{DUVAL}

Township

Range

17S-12E-1/2, 5/6

Well No.

17S-12E-1

17S-12E-1

17S-13E-5

18S-10E-5

18S-11E-2

18S-11E-8

18S-12E-2

18S-12E-5

$18 \mathrm{~S}-12 \mathrm{E}-5$

18S-12E-5

$18 \mathrm{~S}-12 \mathrm{E}-6$

18S-12E-6

$18 \mathrm{~S}-12 \mathrm{E}-5$

18S-12E-6

18S-12E-6

18S-12E-9

18S-12E-6

$19 S-9 E-5 / 6$

19S-10E-9

19S-10E-2

19S-10E-9

19S-10E-5

19S-10E-8

19S-10E-7

19S-11E-9

19S-11E-9

19S-11E-4

20S-9E-4

20S-9E-4

20S-10E-4

20S-10E-5

20S-10E-5

20S-10E-6

20S-10E-6

20S-10E-8

20S-11E-3

21S-8E-7

21S-8E-8/9

$21 \mathrm{~S}-8 \mathrm{E}-8 / 9$

21S-8E-1

$21 \mathrm{~S}-9 \mathrm{E}-5$

21S-9E-9

21S-9E-5

21S-9E-5

21S-10E-2

21S-10E-4
Well Name

Humble \#2 Welder Heirs "F"

Cherryville \# 1 Gorman

Atlantic-Richfield 非F-1 Welder Heirs

Stanolind \# 1-D Farmers Life Insurance

Shell \#1 Duval County Ranch Co.

Humble \#98 White "B"

Waggoner Est. 非 1 Arnstein, et al. Huber, Colorado \& Shell \#1 Hubberd

Shell \# 1 Penwell

Shell 非 1 Hubberd "B"

Shell 非A-3 Weatherby

Shell 非 1 L. C. Weatherby "A"

Shell 非 1 Stegall "A"

Shell 非A-2 Weatherby

Huber \& Shell \#1 1 Stegall

Socony Mobil \& Lacy 非 1 Weatherby

Hamm, et al. \#15 Duval-Hoffman

Huber 非 1 Hoffman, et al.

Sundance \#1 Frost

Atlantic 非 1-A Billings Ranch

Mayfair \#1 Kirkpatrick, et al.

Houston Oil \& Minerals 非 1 Billings

Rowe \#1 Pearl Est.

Harreill, Holbrook \& Coastal States \#1 Lopez

Humble 非 100 Kohler "A"

Eason-Harper 非1-160 Peters Est.

Eason \#1 Peters Est.

Monterey 非 1 Peters

Frost, et al. \#1 Walker

Sunray \#1 Walker

Shell \#1 El Paso-Benavides Ranch

Hamon \#1 Perez, et al.

Hamon \#1 Pedro (STH) Lea

Houston Oil \& Minerals 非 1 Dinn

Morgan \#3-B Richardson

Mobil \#1 Dinn

Gulf \# 1 Gulf-Peters

Texaco \#28 Da Camara

Skelly \#6 Martin

Skelly \# 1 Martin

Gulf \#1 Villareal

Brown, DelMar, \& Dennis 非 1 Laurel Heirs

Atlantic \#1 "A" Garcia Est.

Pauley \#1 Laurel Fee

Amistad \#1 "A" White

Hamon $\mid$ | 1 de Benavides

McCulloch \& Venus \#1 Cuellar 
Township Range

21S-10E-5 21S-10E-7

21S-10E-3

2IS-10E-3

22S-8E-8

22S-9E-2

22S-9E-2

22S-9E-3

22S $-9 \mathrm{E}-4$

22S-9E-4

22S-9E-7

22S-9E-7

22S-9E-7

22S-9E-7

22S-9E-7

22S-9E-7

22S-9E-7

22S-9E-9

22S-9E-2

22S-9E-4
Well No.

3
4
5
6
1
1
3
4
6
8
10
11
12
13
15
17
18
20
21
22

Well Name

Getty 非 1 de Benavides

Union \#1 1 Brennan-Benavides

Standard of Texas \# 1-B de Benavides

Morgan \#2-B de Benavides

Shell \#1 1 Bruni Trust \& Killam Trust

Atlantic 非 1 Garcia Est.

Coastal States \#2 Puig

Atlantic \#1 1 Puig Gas Unit

Hamon 非 I Ramirez

Pickens 非 1 Bruni

Atlantic 非 2 Bruni Gas Unit 非 1

Atlantic \& Austral 非 1 Stroman-Armstrong

Atlantic 非 2 Stroman-Armstrong

Austral 非 1 Marrs McLean Trust

Atlantic-Richfield 非 3 Marrs McLean "C"

Austral 非 Marrs McLean

Coastal States \# 1 Yeager-Armstrong

Atlantic \#A-1 Hinnant

4-B Trust \#1 Laredo National Bank

Atlantic \#1-A Puig 
Township

Range

7S-23E-5

Well No.

7S-23E-7

7S-23E-7

7S-23E-7

$7 \mathrm{~S}-23 \mathrm{E}-7$

$7 \mathrm{~S}-24 \mathrm{E}-3$

$7 \mathrm{~S}-24 \mathrm{E}-7$

$7 \mathrm{~S}-24 \mathrm{E}-8$

$7 \mathrm{~S}-24 \mathrm{E}-9$

$7 \mathrm{~S}-24 \mathrm{E}-5$

$7 \mathrm{~S}-24 \mathrm{E}-8$

7S-24E-7

$8 \mathrm{~S}-21 \mathrm{E}-1$

$8 \mathrm{~S}-21 \mathrm{E}-4$

$8 \mathrm{~S}-21 \mathrm{E}-4$

$8 \mathrm{~S}-21 \mathrm{E}-5$

8S-21E-6

$8 \mathrm{~S}-21 \mathrm{E}-7$

$8 \mathrm{~S}-21 \mathrm{E}-7$

$8 \mathrm{~S}-21 \mathrm{E}-8$

$8 \mathrm{~S}-21 \mathrm{E}-8$

$8 \mathrm{~S}-21 \mathrm{E}-8$

$8 \mathrm{~S}-21 \mathrm{E}-9$

$8 \mathrm{~S}-21 \mathrm{E}-6$

$8 \mathrm{~S}-21 \mathrm{E}-4$

$8 \mathrm{~S}-22 \mathrm{E}-3$

$8 \mathrm{~S}-22 \mathrm{E}-9$

$8 \mathrm{~S}-22 \mathrm{E}-5$

$8 \mathrm{~S}-22 \mathrm{E}-5 / 6$

$8 \mathrm{~S}-22 \mathrm{E}-6$

$8 \mathrm{~S}-22 \mathrm{E}-6$

$8 \mathrm{~S}-22 \mathrm{E}-6$

$8 \mathrm{~S}-22 \mathrm{E}-6$

$8 \mathrm{~S}-22 \mathrm{E}-6$

$8 \mathrm{~S}-22 \mathrm{E}-6$

$8 \mathrm{~S}-22 \mathrm{E}-6$

$8 \mathrm{~S}-22 \mathrm{E}-7$

$8 \mathrm{~S}-22 \mathrm{E}-7$

8S-22 \#-7

$8 \mathrm{~S}-22 \mathrm{E}-7$

$8 \mathrm{~S}-22 \mathrm{E}-7$

$8 \mathrm{~S}-22 \mathrm{E}-8$

$8 \mathrm{~S}-22 \mathrm{E}-8$

$8 \mathrm{~S}-22 \mathrm{E}-9$

$8 \mathrm{~S}-22 \mathrm{E}-5$

8 S-22E-5
Well Name

Avalanche Journal \#1 Palmer, Seekamp, and Rittner

Rowe \#2 Parker

Apache \& N. Central 非 1 Daniels

Patrick $\mid ⿰ 1$ Daniels

Weaver \# 1 Belton

Mobile \#1 Hagen

Shell \#1 Carroll

Argo 非 1 Granberry

Humble 非 1 Kunetka

Lone Star \#1 McManus

Lone Star \#1 Garrett

Humble \#1 Matthews

Gulf \# 1 Mueller

Shell \#1 Brown

Lone Star 非 1 Alex

Atlantic \#1 Smith

International Nuclear $\# 1$ Weber

Commonwealth 非 1 Richards

Scurlock 非 1 Murray

Highland \#1 Wood

- McCulloch \#1 Domann

Brown 非 1 Jablonski

Shell 非 1 Roehl

Superior \# 1 Blackwell

Esperaza \#1 Sheppard

Sterling 非 1 Hamilton

Humble 非 1 Cook

Argo 非 1 Keseling

Coastal States 非 1 Lackey

Viking 非 1 Ward

Venus \#1 Hartman

Gas Producing Enterprises \#1 Miusselman Gas Unit

Texaco \# 1 Jernigan

Harkins \# 1 Jernigan

Harkins 非 1 Henneke

Sun $\# 1$ Henneke Gas Unit

Lone Star \#1 Mueller

Humble \#1 Hartman

Humble \#1 Keseling

Edwards \#1 Keseling

Angelina, Owen \& Smith \#1 Keseling (Unit 非)

Tesoro 非 1 Keseling-Johnson

Humble 非 1 Schorlemer

Tana \#1 White

Scheig 非 1 Brown

Abercrombie 非 1 Williams 
Township

Range

8S-22E-8

$8 \mathrm{~S}-22 \mathrm{E}-8$

$8 \mathrm{~S}-22 \mathrm{E}-9$

$8 \mathrm{~S}-22 \mathrm{E}-9$

$8 \mathrm{~S}-22 \mathrm{E}-5$

$8 \mathrm{~S}-22 \mathrm{E}-5$

$8 \mathrm{~S}-22 \mathrm{E}-1$

$8 \mathrm{~S}-22 \mathrm{E}-6$

$8 \mathrm{~S}-22 \mathrm{E}-2$

$8 \mathrm{~S}-23 \mathrm{E}-1$

$8 \mathrm{~S}-23 \mathrm{E}-1$

$8 \mathrm{~S}-23 \mathrm{E}-1$

$8 \mathrm{~S}-23 \mathrm{E}-2$

$8 \mathrm{~S}-23 \mathrm{E}-2$

$8 \mathrm{~S}-23 \mathrm{E}-2$

$8 \mathrm{~S}-23 \mathrm{E}-2$

$8 \mathrm{~S}-23 \mathrm{E}-3$

$8 \mathrm{~S}-23 \mathrm{E}-3$

$8 \mathrm{~S}-23 \mathrm{E}-3$

$8 \mathrm{~S}-23 \mathrm{E}-4$

$8 \mathrm{~S}-23 \mathrm{E}-4$

$8 \mathrm{~S}-23 \mathrm{E}-4$

8S-23E-4

$8 \mathrm{~S}-23 \mathrm{E}-5$

$8 \mathrm{~S}-23 \mathrm{E}-5$

$8 \mathrm{~S}-23 \mathrm{E}-5$

8S-23E-6

8S-23E-8

8S-23E-9

8S-23E-9

8S-23E-9

8S-23E-9

$8 \mathrm{~S}-23 \mathrm{E}-4$

8S-24E-2

8S-24E-3

$8 \mathrm{~S}-24 \mathrm{E}-3$

8S-24E-4

8S-24E-4

$8 \mathrm{~S}-24 \mathrm{E}-6$

9S-18E-6

9S-19E-6

9S-19E-6

9S-19E-6

9S-19E-6
Well No.
Well Name

Braman \# 1 Keseling

Harkins and Humble \#1 Keseling

Lone Star \#1 Angerstein

Atlantic \#1 Schorre

Catlett \& Ferguson \#1 1 Thomas

Monsanto \#1 Ley

Bridewell 非 1 Burns

Hanover \#1 Sager

Tesoro 非 1 Kirkham, et al.

Arco \# 1 Daniels

Zinn, Mitchell, Lone Star \#1 Daniels

Seeligson \#1 Friar

Apache \& North Central \#1 Friar

Coastal States \#1 Friar

Sinclair \& Coastal States 非 1 Stiles

Brown 10 \# 1 Friar

Texas Gas \#1 Adams

Viking \# 1 Schultz

Osborn 非 1 Wesley

Tidewater \#1 Adams

Argo \#1 McDougal

Lone Star 非 1 Hiller

Viking \#1 Reuss

Texaco \#1 Probst

Texaco \# 1 Cheatham

Coastal States \#1 Legalley and Harwood

Whiffen $\mid$ \# 1 Legalley

Atlantic 非 1 Hartman

Humble \#1 Goebel

Mitchell 非 1 Koenig

Zachry \# 1 Rath

Bright-Schiff 非 1 Brown

Hunt \#1 Garza

Avalanche Journal \# 1 Boothe

Lone Star \#1 Means

Lone Star \#3 Friar

Humble 非 1 Pridgen

Shell \# 1 Blackwell

Shell 非 1 Collum

Occidental \#1 Osterloh

Hunt Trust \#1 Schuenemann

Texas Eastern \#2 Voelkel (\#1 1 Gas Unit)

Texas Eastern 非 1 Mugge

Standard of Texas \#1 Mugge 
Township

Range

9S-19E-8

9S-19E-8

9S-19E-2

9S-19E-7

9S-20E-1

9S-20E-1

9S-20E-1

9S-20E-2

9S-20E-2

9S-20E-3

9S-20E-3

9S-20E-5

9S-20E-5

9S-20E-6

9S-20E-6

9S-20E-6

9S-20E-7

9S-20E-7

9S-20E-7

9S-20E-7

9S-20E-7

9S-20E-7

9S-20E-8

9S-20E-8

9S-20E-8

9S-20E-8

9S-20E-8

9S-20E-8

9S-20E-8

9S-20E-8

9S-20E-8

9S-20E-8

9S-20E-8

9S-20E-9

9S-20E-9

9S-2IE-1

9S-21E-1

9S-21E-1

9S-21E-1

9S-21E-2

9S-21E-2

9S-21E-2

9S-21E-2

9S-21E-3

9S-21E-3
Well No.

6

7

9

11

1

3

4

6
Well Name

Lamar Hunt 非 1 Flenniken

Standard of Texas \#1 Tipton

Union Texas \# 1 Musselman Bank unit

Stone \#1 Waskow Unit

Harper-Smith 非 1 Gips

Southland \#1 Gips

Haxwell 非 1 Gips

Magnolia 非 1 Kleberg

Hamon and Ehman \#1 Kleberg

Dixel \#1 Roeder

Union Texas \#1 Warwas

Monsanto \& Ada \#1 Roberts

Tidewater 非 1 Korth

Harkins \#1 Korth

Holmes 1 Mann

Mortimer \#1 Butler (\#1 Gas Unit)

McCulloch \#1 Hurst

Monsanto \#1 Estrella

Humble 非 1 Guaranty

McCulloch 位 1 Franke

Monsanto \& Bridger \# 1 Green

Cox 非 1 Clark

Colorado \#1 Clark

Monsanto 非 1 Hilgartner

Cox \& Hewitt \# 1 Kleine

Coloma 非 1 Buesing

Hanson, Monsanto, \& MacDonald \# 1 Waskow

Hanson \& Cox \# 1 Buesing

Hanson, Cox and MacDonald \#1 Altman

Hanson, Monsanto, Ada \& MacDonald \#1 1 Kolodzey

M.K. Oil (Hanson) \#1 Dean Trust

Hanson, Cox, Monsanto, Ada \& McDonald '非 1 Rav

Hanson, Cox \& Monsanto \#1 Matejek

Hanson \#1 Schlosser

Brown \#1 Leister

Austral \#1 Schroeter

Argo \#1 Schroeter

Harkins, Gulf, \& Musselman \# 1 Duderstadt

Harkins, Musselman \& Gulf 非 2 Duderstad

Houston Nat. Gas \#3 Boldt

Quintana \#1 Jochen

Monsanto, et al. \#1 Boldt

Commonwealth, Harkins, \& Humble \# 1 Machost

Mobil \#1 Berck

Harkins \#1 Sauermilch 
Township

Range

9S-21E-3

9S-21E-3

9S-21E-4

9S-21E-4

9S-21E-4

9S-21E-4

9S-21E-4

9S-21E-4

9S-21E-4

9S-21E-4

9S-21E-5

9S-21E-5

9S-21E-5

9S-21E-5

9S-21E-6

9S-21E-8

9S-21E-9

9S-21E-9

9S-21E-9

9S-21E-5

9S-21E-2/5

9S-21E-6

9S-21E-4

9S-21E-3

9S-22E-3

9S-22E-3

9S-22E-3

9S-22E-5

10S-17E-7

10S-18E-6

10S-18E-7

$10 \mathrm{~S}-18 \mathrm{E}-5 / 8$

10S-18E-9

10S- $19 \mathrm{E}-1 / 2,5 / 6$

10S-19E-2

10S-19E-2

10S-19E-6

10S-19E-7

10S-19E-9

10S-19E-9

10S-19E-1/6

10S-19E-1

10S-19E-2

10S-19E-4

10S-19E-8/9
Well No.

17

18

20

21

22

23

24

25

26

27

28

29

31

32

33

34

35

36

38

41

42

43

44

45

2

3

4

5

1

3

4

5

8

1

2

3

4

5

6

7

8

9

10

11

13
Well Name

Miusselman 非 1 Danysh, et al. Gas Unit

Brown \#1 1 Henze Gas Unit

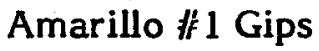

Lone Star \& Musselman \#1 Gips

Hanson \#1 Gips Gas Unit

Lone Star \#1 Gips

Lone Star \#1 Felter

Monsanto and Hughes \& Hughes \#1 Norris

Greenbrier 非 1 Alves

Skelly \# 1 Menn

Monsanto 非 1 Witte

Monsan to 非 2 Houchins

Monsan to \# 1 Fromme

Monsanto 非 3 Kulawik

Brazos (Dow Chem.) 非 1 Sievers

Alcoa \#1 Casper

Atlantic \#1 Ladner

Lone Star \#1 Gips

Atlantic \#1 Kerlick

Monsanto 俳 2 Kulawik

Texaco 非 2 Broughton

Pace \#1 Coleman

Monsan to \#1 Alves

Ada \#1 Jendrzey

Kilroy of Texas \#1 Mueller

LaGloria \# 1 Ferguson

Austral and Crown Central 非 1 Ferguson

Texaco 非 1 Angerstein

General Crude \# 1 Gruntwald

General Crude \#1 Wessendorff

Atlantic 非 1 Pullin, et al.

Hunt 非 1 Huckman

General Crude \#1 McDowell

Cities Service 非 1-A Stanchos

Argo \#1 Dittmer

Mobil \#1 Speary

Cities Service 非 1 Janssen

National Exploration 非 1 Effenberger

Shell 非 1 Atkinson

Shell 非 I-R Atkinson

Cities Service \#1-A Gaus

Kirk and Need \# 1 Mueller Est.

Mobil \# 1 Meyer

Cities Service 非 1 "B" Wood

Hunt \# 1 Zavesky 
DE WITT

Township

Range

Well No.

Well Name

10S-20E-2

1OS-20E-3

1OS-20E-3

10S-20E-3

10S-20E-6

1OS-20E-3

10S-20E-2/3

5

11S-19E-1

11S-19E-1

Atlantic \#1 Skinner

Humble 非 1 Nordheim Gas Unit

Getty \#13 Nordheim

Getty \#11 Nordheim

Lone Star \#1 Jank

Southland 非 1 Fuhrken

Cox \#1 Riedel

Humble 非 1 Meyer

Humle 非 2 McMillan

Lone Star \#1 Haynes Estate

Chevron \# 1 Jacobs

Samedan \#1 Berckenhoff

Haring, Alcoa \& Superior 非 1 Powell

Humble \#1 Neese

Associated Oil \& Halbouty \#1 Von Dohlen

Shell 非 1 Friedrichs 
Township

Range

2S-31E-8

2S-31E-8

2S-31E-8

2S-31E-8

2S-31E-8

2S-31E-8

2S-31E-9

2S-31E-9

2S-31E-8

2S-31E-8

2S-31E-8

2S-31E-8

2S-31E-9

3S-29E-4

$3 \mathrm{~S}-29 \mathrm{E}-3$

$3 \mathrm{~S}-29 \mathrm{E}-2$

3S-29E-6

3S-29E-2

3S-29E- 8

$3 \mathrm{~S}-29 \mathrm{E}-7$

3S-29E-7

3S-29E-7

3S-29E-7

$3 \mathrm{~S}-30 \mathrm{E}-1$

3S-30E-1

$3 \mathrm{~S}-30 \mathrm{E}-1$

$3 \mathrm{~S}-30 \mathrm{E}-2$

$3 \mathrm{~S}-30 \mathrm{E}-2$

$3 \mathrm{~S}-30 \mathrm{E}-2$

$3 S-30 E-2$

$3 \mathrm{~S}-30 \mathrm{E}-4$

3S-30E-4

3S-30E-4

$3 \mathrm{~S}-30 \mathrm{E}-7$

3S-30E-9

3S-30E-5

3S-30E-5

3S-30E-9

3S-30E-9

3S-31E-4

3S-31E-7

3S-31E-8

$3 \mathrm{~S}-31 \mathrm{E}-4$

3S-31E-5

3S-31E-5

3S-31E-8

3S-31E-8

3S-32E-9
Well No.

\section{Well Name}

Mound \# 1 Newsome

Delhi-Taylor \# 1 Hillboldt

Shell 非 1 Hintz

Shell 非 2 Hillboldt

Shell 非 1 Cole

Mound \#1 Hillboldt

Delhi-Taylor \#1 Findeisen

Shell \# 1 Sealy Gas Unit

Mound 非 1 Konesheck

Ranger \# 3 Hintz Estate "A"

Ranger \#1 1 Finke

Shell 非 5 Hillboldt

Scurlock \#1 Kulow-Bielefeld Unit

Evans 非 1 Wilson

House and Amer. Republics \#1 Tolbirt

Cummins and Walker \# 1 Nelson

Skelly 非 1 Stringer

Texas $\mid$ I 1 Coddou

King Resources 非 1 Lyle

Prairie \# 1 Thomas

Cities Service \#B-2 Stephens

Cities Service \#1 1 Pode

Cities Service 非A-2 Pode

Carthay 非 I Ludwig

Boston \#A-1 Frobel

Alcoa and Boston \# 1 Amthor

Intercoastal \# 1 Krueger

Hanson and McCormick \#1 Krueger

International Nuclear 非 1 Weishun

Union \# 1 Glueck

King Resources 非 1 Wintermann

Natural Resources 非 Wintermann

King Resources \# 1 Herder

Gray \# 1 Vineyard and Foster

National Resources 非 1 Birdwell

Newmont and Tidewater \#1 Everett

Apexco \#1 1 Meir

Cico \#2-A Wintermann

Hanson \# 1 Wintermann

Gray \# 1 Bonnette

International Nuclear 非 1 Odom

Humble \#1 Hillboldt

Hillard \#1 Hillboldt

Sundance and Stuarco \#3-A Best

Sundance, May, and Stuarco \#2 Best

Texas \#1 Kaechele

Humble \#1 Kaechele

Southern $\| 1$ Unyrek 
Township

Range

4S-29E-3

4S-29E-3

4S-29E-4

4S-29E-8

4S-29E-5

4S-29E-2

4S-29E-2

4S-29E-9

4S-29E-8

4S-29E-8

4S-29E-1

4S-29E-7

4S-29E-3

4S-29E-2

4S-29E-3

4S-29E-3

4S-29E-4

4S-29E-1

4S-29E-3

4S-29E-4

4S-29E-4

4S-29E-9

4S-29E-2

4S-30E-1

4S-30E-1

4S-30E-2

4S-30E-4

4S-30E-5

4S-30E-5

4S-30E-6

4S-30E-6

4S-30E-7

4S-eOE-8

4S-30E-8

4S-30E-8

4S-30E-9

4S-30E-9

4S-30E-8

4S-30E-3

4S-30E-3

4S-30E-5

4S-30E-7

4S-30E-8

4S-30E-6

4S-30E-6

4S-31E-4

4S-31E-7

4S-31E-9

4S-31E-4

4S-31E-9

4S-31E-4
Well No.

1

2
Well name

Superior \#D-1 Tait

Superior \#D-2 Tait

Skelly \#1 Johnson

Shell 非 1 Kyle Est.

Brazos \#1 1 Struss

Tidewater \#1 Brandon

Skelly \# 1 Walker

Bright and Schiff \#1 Struss

Texas \# 1 Johnson

Texas \# 1 Bunge

Skelly 非 1 Wintermann

Rain and Buck非 1 Duncan

British-American 非 1 Wells

Continental 非 1 Tait

Superior \# 1 Tait

Superior \#1 Tait

Fidelity 非 1 Dodson

Dow 非 1 Lange

Superior "D" 3 Tait

Superior \#1 Meyer

Parker Bros. \#1 Parker Bros. Fee

Fidelity 非 1 Struss

Mosbacher 俳 1 Tait

Shell \#2 Hayes Stephens

Clark-Sherwood \#1 Stephens Gas Unit

Union \#1 Thomas

Brown 非 1 Wintermann

Tex-Star 非 1 Haley Trust

Mosbacher and Harkins \# 1 Foster

Shell 非 1 Martin

Fidelity \#1 Hoyo

Midwest \#1 Haley

Mosbacher \#1 Duncan

Starr \# 1 Wintermann

Frio 非 1 Waddell

Fidelity 非 1 Duncan

Cherry \#1 Wintermann Est.

Sun \# 1 Duncan

Mutex \#3-B Wintermann

Chicago Co. and Skelly Oil \#1 1 Dennis

Flaitz 非 1 Hoyo

Clover and Hanover \#1 Harrison

Scurlock \#1 Duncan-Wintermann Unit

Barnwell \#1 Colorado

Fidelity 非 1 Bridge

Crosby \#1 Poole

Getty \# 1 Leveridge

Newmont \# 1 Poole

Humble 非 1 Thomas

Magnolia \#1 Poole

Humble \#1 Isenhower 
Township

Range

5S-29E-1

$5 \mathrm{~S}-29 \mathrm{E}-3$

$5 \mathrm{~S}-29 \mathrm{E}-1$

$5 \mathrm{~S}-29 \mathrm{E}-2$

$5 \mathrm{~S}-29 \mathrm{E}-3$

$5 \mathrm{~S}-30 \mathrm{E}-1$

$5 \mathrm{~S}-30 \mathrm{E}-1$

$5 S-30 E-3$

$5 \mathrm{~S}-30 \mathrm{E}-3$
Well No.

1

2

3

4

6

1

2

3

4
Well Name

Socony-Mobil \#5 Gracey

Halbouty 非 1 Lehrer

Shell 非 1 Thompson

Shell 非 1 Hudson

Mosbacher, Superior and National \#1 Zinn Lehrer

General Crude 非 1 Wintermann

General Crude 非 3 Wintermann

Brazos 非 1 Matthews

Miagnolia \# 1 Gracey-Wegenhoff 
Township

Range

$5 \mathrm{~N}-38 \mathrm{E}-5$

$5 \mathrm{~N}-38 \mathrm{E}-7$

$5 \mathrm{~N}-38 \mathrm{E}-8$

$5 \mathrm{~N}-38 \mathrm{E}-8$

$5 \mathrm{~N}-38 \mathrm{E}-8$

$5 \mathrm{~N}-38 \mathrm{E}-8$

$5 \mathrm{~N}-38 \mathrm{E}-8$

$5 \mathrm{~N}-38 \mathrm{E}-8$

$5 \mathrm{~N}-38 \mathrm{E}-8$

$5 \mathrm{~N}-38 \mathrm{E}-8$

$5 \mathrm{~N}-39 \mathrm{E}-3$

$5 \mathrm{~N}-39 \mathrm{E}-7$

$5 \mathrm{~N}-39 \mathrm{E}-7 / 8$

5N-39E-8

5N-40E-6

5N-40E-6

$5 \mathrm{~N}-41 \mathrm{E}-4$

5N-41E-4

$5 \mathrm{~N}-41 \mathrm{E}-4$

5N-41E-4

$5 \mathrm{~N}-42 \mathrm{E}-9$

4N-35E-7

4N-36E-6

4N-36E-6

4N-36E-6

$4 \mathrm{~N}-36 \mathrm{E}-9$

4N-36E-6

4N-37E-6

4N-37E-7

4N-37E-7

4N-37E-7

$4 \mathrm{~N}-37 \mathrm{E}-8$

4N-37E-8

$4 \mathrm{~N}-37 \mathrm{E}-8$

4N-37E-7

4N-37E-7

$4 \mathrm{~N}-38 \mathrm{E}-1$

$4 \mathrm{~N}-38 \mathrm{E}-1$

$4 \mathrm{~N}-38 \mathrm{E}-1$

$4 \mathrm{~N}-38 \mathrm{E}-1$

4N-38E-2

$4 \mathrm{~N}-38 \mathrm{E}-2$

$4 \mathrm{~N}-38 \mathrm{E}-3$

$4 N-38 E-4$
Well No.

1

2

3

4

5

6

7

8

9

10

1

3

4

6

1

2

1

3

5

6

2

1

1

2

3

4

5

Well Name

Cities Service 非B-I Browder

Texas City \#1 Elmore

Dominion 非 Elmore, et al.

Dominion \#1 Elmore

Houston \# 1 Lewis Unit

Cities Service 非 1 Ellisor

Triton \#1 Roche-Ellisor

Barnes \#1 Johnson

Cities Service \#1 Melvin Unit

Cities Service 非 1 Browder

Glen Rose \#1 Cary Heirs

Standard of Texas 非 1 Foster

Shell 非 1 Coline

Reserve 非 2 Richards

Sun \#1 McGowan Unit 1

Viking \& De Lange \#1 Langham Gas Unit

Amoco \#A-3 Langham

Pan American \#B-2 Langham

Stanolind 非B-1 Langham

Stanolind \#C-1 Langham

Sunray \#1 Bell

Capital \#1 Alliance Trust

Superior \& Speed \#1 Elam

Super \& Speed 非 1 Sykes

Moran \#1 Sykes

Cities Service 非 1 Madeley

Sunset International \#1 Shaver

Oil Reserves 非 1 Foster Est.

Moran \#3-A Hutchins-Sealy Nat. Bk.

Moran \#3 Hutchins-Sealy Nat. Bk.

Moran \#2-A Hutchins-Sealy Nat. Bk.

Texmo 非 1 Hutchins-Sealy Nat. Bk.

Texmo-Brown \#1 Gas Unit \#2

Kirby (McKay \& Donkin, et al.) 非 1 Rawson

Glen Rose \#1 Champion

Moran \#1-B Hutchins-Sealy Nat. Bk.

Continental $\mid$ 非 Gibbs

Continental 非 2 Gibbs

Huber Co. 非 1 Gibbs

Texas City 非 1 Foster Est.

Cities Service \#1 Frazer \& Campbell

Dominion 非 1 Campbell

Continental \#1 Frazier

Donkin \& Smith \#1 Browder 
Township

Range

$4 \mathrm{~N}-38 \mathrm{E}-4$

$4 \mathrm{~N}-39 \mathrm{E}-3$

$4 \mathrm{~N}-39 \mathrm{E}-3$

$4 \mathrm{~N}-39 \mathrm{E}-4$

$4 \mathrm{~N}-39 \mathrm{E}-7$

$4 \mathrm{~N}-39 \mathrm{E}-7$

$4 \mathrm{~N}-39 \mathrm{E}-8$

$4 \mathrm{~N}-39 \mathrm{E}-8$

$4 \mathrm{~N}-39 \mathrm{E}-8$

$4 \mathrm{~N}-39 \mathrm{E}-9$

$4 \mathrm{~N}-40 \mathrm{E}-1$

$4 \mathrm{~N}-40 \mathrm{E}-1$

$4 \mathrm{~N}-40 \mathrm{E}-4$

$4 N-40 E-8$

4N-40E-8

4N-41E-9

4N-41E-1

4N-41E-6

3N-33E- 8

$3 \mathrm{~N}-33 \mathrm{E}-8$

$3 N-33 E-8$

3N-33E- 8

$3 \mathrm{~N}-33 \mathrm{E}-8$

$3 \mathrm{~N}-34 \mathrm{E}-7$

$3 \mathrm{~N}-34 \mathrm{E}-7$

$3 \mathrm{~N}-34 \mathrm{E}-8$

$3 \mathrm{~N}-34 \mathrm{E}-8$

$3 \mathrm{~N}-36 \mathrm{E}-1$

$3 \mathrm{~N}-36 \mathrm{E}-4$

$3 \mathrm{~N}-36 \mathrm{E}-7$

$3 \mathrm{~N}-36 \mathrm{E}-7$

$3 \mathrm{~N}-36 \mathrm{E}-7 / 8$

$3 \mathrm{~N}-36 \mathrm{E}-8$

$3 \mathrm{~N}-36 \mathrm{E}-8$

$3 \mathrm{~N}-36 \mathrm{E}-8$

$3 \mathrm{~N}-36 \mathrm{E}-8$

$3 \mathrm{~N}-36 \mathrm{E}-8 / 9$

$3 \mathrm{~N}-36 \mathrm{E}-9$

$3 \mathrm{~N}-36 \mathrm{E}-9$

$3 \mathrm{~N}-36 \mathrm{E}-9$

3N-37E-4

$3 N-37 E-5$
Well No.
Well Name

Moran 非 1 Browder

Prairie \& Convest \# 1 Gibbs, et al.

Impact 非 1 Mays

Continental 非 1 Mays, et al.

Amerada \& Mid-States \# 1 Central Coal \& Coke Russell \& Moran \# 1 Central Coal \& Coke Shell 非 11 Central Coal \& Coke

Superior \#1 Foster

Manning \# 1 Central Coal \& Coke

Fain \#1 Baldwin

Texas Gas Exploration 非 1 Ogletree

Magnolia 非2 Dixon-Falvey

Magnolia 非 1 Hinchliff-Simms

Magnolia \& Ambercrombie 非 1 Brewer

Davis 1 I Sims

Oil Reserves \#1 1 Jefferson

Continental \& Speed \#1 Frost

Pan American \#1 Moore Est.

Gulf 非 Gardner

Millican 1 Gardner

Gulf \# 1 Gardner

Atlantic 非 1 Sanders

Millican \#1 Baner

Colorado 非 1 Rice University

Gallery \#1 Thompson

McCarthy \#1 Gibbs-Elgin, et al.

Standard of Texas 非 Sanders, et al.

Feldman 非 1 Teas

Socony-Mobil \#1 Sealy-Smith Fd.

Prairie \& Convest 非 1 Madeley, et al.

Delhi-Taylor 非2 Sealy-Smith Fd.

Delhi-Taylor \#1 Sealy-Smith Fd.

McCulloch \& Venus \# 1 Frost

Prairie \#1 Frost, et al.

Superior \#3 Frost

Superior \#1 Frost

Mecam \# 1 Bertrand

Stanolind 非 1 William

Sinclair \#1 Grogan

Mitchell \#1 Asche, et al.

Moran 非 1 Cartwright

Hagen \& Litchfield \#1 Harris \& Freeman 
Township

Range

$3 \mathrm{~N}-37 \mathrm{E}-8$

$3 \mathrm{~N}-37 \mathrm{E}-8$

3N-37E-9

3N-37E-9

$3 \mathrm{~N}-37 \mathrm{E}-9$

$3 \mathrm{~N}-38 \mathrm{E}-1$

$3 \mathrm{~N}-38 \mathrm{E}-5$

$3 \mathrm{~N}-39 \mathrm{E}-1$

$3 \mathrm{~N}-39 \mathrm{E}-1$

$3 \mathrm{~N}-39 \mathrm{E}-2$

$3 \mathrm{~N}-39 \mathrm{E}-2$

$3 \mathrm{~N}-39 \mathrm{E}-5$

$3 \mathrm{~N}-39 \mathrm{E}-5$

$3 \mathrm{~N}-39 \mathrm{E}-5$

$3 N-39 E-8$

$3 \mathrm{~N}-39 \mathrm{E}-5$

$3 \mathrm{~N}-39 \mathrm{E}-5$

$3 \mathrm{~N}-39 \mathrm{E}-5$

$3 \mathrm{~N}-39 \mathrm{E}-8$

$3 N-39 E-6$

3N-39E-6

$3 N-39 E-6$

$3 N-39 E-6$

$3 N-39 E-7$

$3 N-39 E-8$

$3 N-39 E-5$

$3 N-39 E-6$

$3 N-39 E-6$

$3 \mathrm{~N}-39 \mathrm{E}-7$

$3 \mathrm{~N}-40 \mathrm{E}-1$

$3 N-40 E-1$

$3 N-40 E-1$

$3 \mathrm{~N}-40 \mathrm{E}-1$

$3 \mathrm{~N}-40 \mathrm{E}-1$

$3 \mathrm{~N}-40 \mathrm{E}-1$

$3 N-40 E-2$

$3 N-40 E-3$

$3 \mathrm{~N}-40 \mathrm{E}-8$

$3 \mathrm{~N}-40 \mathrm{E}-8$

$3 \mathrm{~N}-40 \mathrm{E}-9$

3N-40E-9

$3 \mathrm{~N}-40 \mathrm{E}-9$

$3 N-41 E-3$

$3 \mathrm{~N}-41 \mathrm{E}-3$

$3 N-41 E-3$

$3 N-41 E-4$

2N-32E-5

2N-32E-6

Well No.

3

4

5

6

7

1

2

Well Name

Skelly \# 1 Tipton

Humble \#1 Grande Lake Gas Unit \#2

Humble \#1 Grande Lake Gas Unit \#1

Humble \#2 Grande Lake Gas Unit \#1

Humble \# 1 Council

Cazoline Hunt Sands \#1 San Jacinto Trust

Texaco \#1 Griffin

Atlantic 非 1 White

Trice 非 1 Foster

Cauble 非 1 Combe Heirs

Gulf \#1-A Foster

Rowan \#1 Dunnam

Atlantic 非 1 Foster

Halbouty \# 1 Foster-Gulf

Pure Oil 非 1 Foster

Halbouty \#1-B Foster

Habouty \#2 Foster

Halbouty 非 1-A Foster

Union \& Halbouty \#E-1 Foster

Amerada 非 1 Foster

Halbouty 非 1 Godejohn

Amerada \#1 Godejohn

Halbouty 非 Burkett

Halbouty \#1 Leggett

Halbouty 非 1 Southland Paper

Sohio \& Leben \# 1 Kingswood, et al.

Sanchez-O'Brien \# 1 Friendswood

Sanchez-O'Brien \#1 Friendswood

Halbouty \#1 Todd

Sun \#1 Quinn

Karsten \#5-A Quinn

Houston Mineral \#1 Ott Gas Unit

Pan American \# 1 Howard

Ohio \#1 Quinn

Pan American \#A-1 Kirby

Sundance \# 1 Davis

Mitchell \#1 Cherry

Superior \#1 Bosworth

Hunt 非 1 Grogan

Superior \# 1 Hightower

Superior 非 1 Hightower

Humble \#1 McDonald

Humble \#1 Smith

Cherryville \#1 Jackson

Brazos \#1 Ballard

Porter \& Phillips 非 1 Champion

Continental Thomas \& Scardino

Harrison 1 促 Gaines 
HARRIS

Township Range

2N-32E-7

$2 \mathrm{~N}-33 \mathrm{E}-4$

2N-33E-4

$2 \mathrm{~N}-33 \mathrm{E}-4$

2N-33E-2

2N-33E-2

2N-34E-3

$2 \mathrm{~N}-34 \mathrm{E}-3$

2N-34E-3

2N-34E-4

$2 \mathrm{~N}-34 \mathrm{E}-4$

$2 \mathrm{~N}-34 \mathrm{E}-5 / 6$

$2 \mathrm{~N}-34 \mathrm{E}-5 / 6$

2N-34E-7

2N-34E-7

$2 \mathrm{~N}-35 \mathrm{E}-2$

$2 \mathrm{~N}-35 \mathrm{E}-2$

$2 \mathrm{~N}-35 \mathrm{E}-2$

2N-35E-2

2N-35E-3

2N-35E-3

$2 \mathrm{~N}-35 \mathrm{E}-3$

2N-35E-4

2N-35E-4

2N-35E-4

2N-34E-4

2N-35E-5

2N-35E-5

$2 \mathrm{~N}-35 \mathrm{E}-4$

$2 \mathrm{~N}-35 \mathrm{E}-5$

2N-35E-5

$2 \mathrm{~N}-35 \mathrm{E}-5$

2N-35E-8

2N-35E-9

2N-35E-1

2N-35E-1

2N-35E-1

2N-35E-1

2N-35E-1

2N-35E-1

$2 \mathrm{~N}-36 \mathrm{E}-1$

$2 \mathrm{~N}-36 \mathrm{E}-1$
Well No.

Well Name

Sinclair \#1 McDade

Brazos 非 1 Sledge

Sun 1 I Von Blucher

Mana \#1 Smith

Brazos 非 1-A Connell

Sun-Indiola \#1 Connell

Strake 非 1 Humphries

Speed 非 1 Sauerbrunn, et al.,

Texas 非 1 Humphries

Associate, et al. \#1-A Rice University

Texas 非 1 Rice University

Superior 非 1 Brown

McCarthy 非 1 Tucker

Enterprises \# 1 Welch Foundation

Ashland \#1 Welch Foundation

Gray Wolfe \#4 Pan Am

Gray Wolfe \#3 Pan Am

Pan Am \#1 Posey

La Gloria 非 2 Cochran

Hawkins \& Hawkins \#1 Von Streety

Christie, Mitchell, \& Mitchell \#1 Von Streety

Standard of Texas 非 1 Dean, et al.

Humble \#1 Lewis, et al.

Superior 1 Kramer

Gose \#1 Kramer

Mitchell \#1 Hagen

Superior Oil \#3-A Dean

Superior \#A-1 Dean

Gray Wolfe $\$ 6$ Pinehurst

Superior \#2-A Dean

Gray Wolfe 非 3 Pinehurst

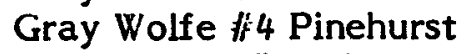

Commercial 非 1 Pills \& Leyle

Pan Am \#1 Welch Foundation

Superior \#A-5 McWhorter

Superior \#2-C McWhorter

Superior \#1-C McWhorter

Superior \#1-D McWhorter

Superior \# 4-A McWhorter

Progress \#1 Winslow

Superior 非 1 McMahon

Texaco \#1 Winslow 
HARRIS

Township

Range

$2 \mathrm{~N}-36 \mathrm{E}-2$

$2 \mathrm{~N}-36 \mathrm{E}-2$

$2 \mathrm{~N}-36 \mathrm{E}-2$

$2 \mathrm{~N}-36 \mathrm{E}-2$

$2 \mathrm{~N}-36 \mathrm{E}-3$

$2 \mathrm{~N}-36 \mathrm{E}-3$

$2 \mathrm{~N}-36 \mathrm{E}-3$

$2 \mathrm{~N}-36 \mathrm{E}-3$

$2 \mathrm{~N}-36 \mathrm{E}-3$

$2 \mathrm{~N}-36 \mathrm{E}-3$

2N-36E-3

$2 \mathrm{~N}-36 \mathrm{E}-5$

$2 \mathrm{~N}-36 \mathrm{E}-6$

2N-36E-6

$2 \mathrm{~N}-36 \mathrm{E}-7$

$2 \mathrm{~N}-36 \mathrm{E}-8$

$2 \mathrm{~N}-36 \mathrm{E}-2$

$2 \mathrm{~N}-36 \mathrm{E}-3$

$2 \mathrm{~N}-36 \mathrm{E}-3$

$2 \mathrm{~N}-37 \mathrm{E}-4$

2N-37E-4

2N-37E-7

2N-37E-9

2N-37E-9

2N-38E-1

$2 \mathrm{~N}-38 \mathrm{E}-5$

2N-38E-7

$2 \mathrm{~N}-38 \mathrm{E}-7$

$2 \mathrm{~N}-38 \mathrm{E}-7$

$2 \mathrm{~N}-38 \mathrm{E}-2$

$2 \mathrm{~N}-38 \mathrm{E}-2$

2N-39E-1

2N-39E-2

$2 / 3 \mathrm{~N}-39 \mathrm{E}-2 / 8$

$2 \mathrm{~N}-39 \mathrm{E}-4$

$2 \mathrm{~N}-39 \mathrm{E}-4$

2N-39E-5

2N-39E-6

$2 \mathrm{~N}-39 \mathrm{E}-6$

2N-40E-2

2N-40E-2

$2 \mathrm{~N}-40 \mathrm{E}-2$

2N-40E-2

$2 \mathrm{~N}-40 \mathrm{E}-2$

2N-40E-2

2N-40E-5
Well No.
Well Name

International Nuclear \& Prairie \#1 M \& $M$ Stanolind \# 1 McMahon

Royal \# M \& M

Magnolia \#1 Chase National Bank

Superior \#A-7 McWhorter

Stanolind \#A-1 South Texas

Superior \#1 Brown

Superior 非 30 Lake Creek

Superior 非 1 South Texas

Superior \#1 $M$ \& $M$

Del Mar 非 1 South Texas

Moran 非 $1 M$ \& $M$

Superior 非 1 Foley

Sohio, Mesa \& Southern \#1 1936 Development

Shell \#1 Peden

Shell \#1 Holderreith

Vaquero \#B-1 M \& M

Superior \#3 South Texas

Superior 非 2 South Texas

Sinclair \#1 Grogan-Cockran

Sinclair \#1 Porter

Texaco 非 1 Bender

Shenandoah 非 1 Evans

McDaniel \# 1 Baldwin

Atlantic 非 1 South Texas

Standard of Texas 11 Anderson, et al.

Winwell 非 1 Schwing

Lacal \#1 Schwing

Humble \#1 Wickizer

Humble \# 1 Hines

Goodale Bertman \#1 Maynard

Samedan 非 1 Coleman

Humble 非B-1 Long Leaf

Kurth Trustee 非 4 Southland Paper

Humble \#1 Ovalline

Sinclair 非 1 Foster

Humble 非 Patton

Union \#1 Foster

Atlantic 非 1 Foster

Humble \#B-1 Quinn

Sun 非 2 Quinn

Sundance 非 1 Quinn

Sun 非 1 Quinn

Gulf \#C-1 Quinn

Allday \& Hammax \#1 Quinn

Sun 1 1 Friendswood 
Township

Range

1N-30E-5

$1 \mathrm{~N}-31 \mathrm{E}-1$

$1 \mathrm{~N}-31 \mathrm{E}-9$

$1 \mathrm{~N}-33 \mathrm{E}-1$

1N-35E-8

1N-37E-1/2

IN-37E-2/3

IN-37E-8

$1 \mathrm{~N}-38 \mathrm{E}-3$

$1 \mathrm{~N}-38 \mathrm{E}-3$

1N-38E-3

1S-32E-3

1S-33E-6

1S-33E- 8

1S-33E-7

1S-33E-8

1S-35E-4

IS-35E-4

IS-35E-4

1S-35E-5

IS-35E-8

IS-35E-2

1S-36E-8

1S-37E-1

1S-37E-2

1S-37E-2

1S-37E-3

1S-37E-3

1S-37E-1

1S-37E-4

1S-37E-3

1S-37E- 3

2S-33E-1

2S-33E-5

2S-33E-6

2S-33E-6

2S-33E-6

2S-33E-6

2S-33E-6

2S-33E-6

2S-33E-6

2S-33E-6

2S-34E-8

2S-34E-9

2S-34E-4

2S-34E-4

2S-34E-4

2S-34E-9

2S-35E-8

$3 \mathrm{~S}-33 \mathrm{E}-3$

$3 \mathrm{~S}-34 \mathrm{E}-2$

3S-34E-9

3S-34E-9
Well No.
Well Name

Holmes \& Mosbacher 非 1 Wright

Karsten \# 1 Menke

Skelly \# 1 Sander

Sinclair \# 1 Krezdorn

Texaco \#1 Mergele

Humble \#1 Bender

Humble \# 1 Baldwin

Houston Nat. Gas 非 1 Tanneberger

Mobile \#1 Bender Est.

Continental \# 1 Bender Est.

Texaco \# 1 Bender

Humble 非 17-B Hardy "B"

Humble \#1 1 Sparks

Halbouty 非 1 Harris, et al.

Exxon HW-46 K.G.F.U. \#2

Pet-Tex \#1 Harris

Standard of Texas \#1-1 Logenbaugh

Standard of Texas \# 1 Josey, et al.

Scurlock \# 1 Josey

Texaco \#1 1 Sweeney Est.

Standard of Texas \#1 Millinger, et al. \#4

Roeser \& Pendleton 非 1 Townes

Pan American 非 1 Brown

Meredith, et al. 非 1 Ross, et al.

Ginther, Warren \#1 Taub-Dwyer-McCall Unit \#1

Sunset \#1 Hamill

Houston Nat. Gas \#1 Hamill Gas Unit \#1

Texaco 非 1 Sweeney Gas Unit 非 1

Texaco \#1 Sharman Gas Unit \#1

Texaco 非 1 Rodgers

Houston Nat. Gas \#1 Hamill Gas Unit \#1

Houston Nat. Gas \#1 Hamill Gas Unit \#3

Exxon \#W-45 K.G.F.U.

Houston Nat. Gas \& Halbouty \#1 Ainsworth

Stanolind 非 Freeman (\#8 K.G.F.U. Unit 1)

Humble \#W-31 K.G.F.U.

Humble 非W-32 K.G.F.U.

Exxon \#W-44 K.G.F.U.

Exxon \#W-38 K.G.F.U.

Humble \#W-34 K.G.F.U.

Exxon \#W-41 K.G.F.U.

Humble \#33 K.G.F.U. \#1

Scurlock 非 1 Arnold

Scurlock 非 1 McMillian

Exxon \#W-43 K.G.F.U.

Exxon \#W-35 K.G.F.U.

Exxon \#W-42 K.G.F.U.

Exxon \#W-36 K.G.F.U.

Conroe. 非 1 Addicks

Mound \#1 England, et al.

Scurlock 非 1 Meek

Ensearch \# 1 Foster Farms

Mobil 非 1 Foster Farms 
Township

Range

23S-8E-5

23S-8E-2

23S-8E-6

23S-8E-7

23S-8E-9

23S-8E-6

23S-8E-5

23S-8E-1

23S-8E-8

23S-8E-1

23S-8E-1

23S-9E-1

23S-9E-1

23S-9E-1

23S-9E-2

23S-9E-3

23S-9E-1

24S-7E-1

24S-8E-7

24S-8E-7

24S-8E-7

24S-8E-7

24S-8E-6

24S-9E-1

24S-9E-3

24S-9E-3

24S-9E-3

24S-9E-8/9

25S-7E-2

25S-7E-3

25S-7E-6

25S-7E-3

25S-7E-6

25S-7E-4

25S-7E-6

25S-7E-8

25S-7E-8

25S-7E-8

25S-7E-8

25S-7E-8

25S-7E-8

25S-7E-8

25S-7E-5

25S-7E-5

25S-7E-5

25S-7E-5
Well No.

1

2

4

5

6

7

8

9

10

11

12

1

2

4

5

6

7

1

1

2

3

4

5

1

2

3

4

5

1

2

3

4

5

6

7

9

10

11

12

14

15

16

17

18

19

20
Well Name

Belco 非 1 Frost Bank

Killam and Hurd 非 1 Fulbright, et al.

Atlantic \#1 Lopez

Union $\mid ⿰ l$ Cuellar

Hughes and Hughes \& Pennzoil \# 1 Martinez

Hughes and Hughes 非 1 Fulbright

Hughes and Hughes \#A-1Uribe Est.

Killam and Hurd 1 1-16 Killam Fee

Hughes and Hughes \#1-B Cuellar Est.

Killam and Hurd 1 I Uribe

Atlantic \# 1 Hinnant

Atlantic Richfield \#4-C Marrs McLean

Atlantic Richfield 非-C McLean

Standard \#2 Holbein

Hamon \# 2 Holbein

Atlantic \#1-B Hinnant

Atlantic Richfield \#2-C McLean Trust

Blanco \#1 Jennings

Halbouty and Jonnel 非 1 Garza

Lively and Fountain \#1 Trevino, et al.

Halbouty \# 1 Trevino

Halbouty and Jonnel 非D-1 Garza

Gulf 非 1 Trevino

Standard \# 1 Frost

Gulf \# 1 Vela

Union \#18 Jennings

Gulf \#1 Garza

Standard 非 1 Blanco

Gulf \#1 Flores

Gulf \# I Ramirez

General Crude (Gulf) \#1 1 Romero

Killam and Hurd-Ryan, et al. \#1 Flores Heirs

Samedan \#1 Matles

Coastal States 非 1 Flores

Rutter, Wilbanks, \& Rutter 非 1 Volpe

Gulf \# 1 Pena

Alaska Steamship, Texita, and Gil

\#1 Cuellar

Osage \# 1 Uribe

MacDonald \# I Uribe

Rio Grande Valley \# 1 Dodier

Miller and Fox 非 1 Dodier

Coastal States $\$ 4$ Dodier

KRM \#1 Volpe

McAll 非 3 Singer

McDaniel \#1 Singer

Bateman 非 1 Gutierrez 


\section{ZAPATA}

Township

Range

25S-7E-5

25S-7E-5

25S-7E-5

25S-7E-9

25S-7E-9

25S-7E-9

25S-8E-1

25S-8E-1

$25 \mathrm{~S}-8 \mathrm{E}-4 / 5$

$25 \mathrm{~S}-8 \mathrm{E}-4 / 5$

25S-8E-5

25S-8E-5

25S-8E-6

25S-8E-7

25S-8E-8

25S-8E-9

25S-8E-9

25S-8E-8

25S-8E-8

25S-9E-9

26S-7E-8

26S-7E-8

26S-7E-8

26S-7E-8

26S-8E-1/6

26S-8E-2

26S-8E-3

26S-8E-5

26S-8E-5

26S-8E-5

26S-8E-8

26S-8E-8

26S-8E-8

26S-8E-8

26S-8E-9

26S-8E-8

26S-8E-5

26S-8E-5

26S-8E-8

27S-7E-7

27S-7E-1

27S-7E-3

27S-8E-3

27S-8E-3

27S-8E-3

27S-8E-3

27S-8E-4

27S-8E-8

27S-8E-9

27S-8E-9
Well No.
Well Name

Miles \# 1 Ramirez

McAll 非 1 Gutierrez

Rowe \#1 Flores

Alaska Steamship \# 1 Vasquez

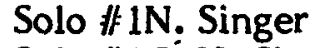

Solo \#1 1 I. M. Singer

Halbouty \#1-E Garza

Blanco and Dougherty \#1 Benavides

Pennzoil \#4 Haynes

Pennzoil \& Patrick \#2 Haynes Est.

Pennzoil 非 1 Haynes

Humble \#1 Haynes Est.

Gulf 非 Security Nat. Bank of L.A., Calif.

Gulf 非 1 Trevino

Crescent 非 1 Haynes

Pennzoil 非 1 Vela

Gulf \#1 Volpe

Bright \& Schiff 非 1 Vela

Pennzoil 非 1 Vela

Hamon \# 1 Campbell

Texas \# 1-M Guerra

Stanolind \# 1 Serafic Nela

Texas \# 1 Guerra

Hamon \#1 1 Alexander

Suburban \#1 Sanchez

Katz 非 1 Vela

Standard of Texas \#1 Garcia

Traman \#1 Garcia

Crescent, et al. \# 1 Morales

Tenneco \# 1 Garcia

Crescent 非 1Foss

Gulf 非 1 Benavides

Crescent 非 2 Benavides

Jonnell 非 3 Benavides

Frankfort 非 1 Benavides

Clinton \# 1 Benavides

Irahan $\# 1$ Whittier

Crescent 非 1 Vela

Jonnell 非 1 Zamora

Standard of Texas \#1 Ramirez

Fullerton \#1 Vela

National \#1 Barberio

Hudson \#1 1 Zamora

Frankfort 非 1 Sanchez

Frankfort 非 1 Garcia

Jonnell \#1 Lopez Heirs

Gosden 非 1 Ramirez

Union \# 1 McDermit

Jonnell \#1 1 Yzaguirre

Jonnell \#1 Ranos 
Township

Range

27S-8E-9

27S-8E-9

27S-8E-4

$27 \mathrm{~S}-8 \mathrm{E}-9$

$27 \mathrm{~S}-8 \mathrm{E}-4$

$27 \mathrm{~S}-8 \mathrm{E}-4$

$27 \mathrm{~S}-8 \mathrm{E}-4$

27S-8E-9

27S-8E-9

$27 \mathrm{~S}-8 \mathrm{E}-9$

27S-8E-2

27S-9E-4

28S-7E-1

28S-7E-1

28S-7E-1

28S-8E-1/2

28S-9E-4
Well No.

Well Name

Jonnell \#1-A Guerra

Jonnell \#2 Ranos

Ashland \# 1 Munoz

Standard of Texas 非 Ramirez

Katz \# 1 Ramirez

Jonnell \& Sohio \#2 Ramirez

Delhi 非 2 Ramirez

Jonnell \#2 M. Ramirez

Jonnell \#2 B. Ramirez

Jonnell \#1 Guerra

Frankfort 非 2 Sanchez

Sun 非 1 Guerra Gas Unit

Hamon \& Colorado 非 1 Guerra

Hamon 非 1 Yzaguirre

Hamon \#1-A Ramirez

Humble 非 1 Humble-Martinez

Austral 非 1 Sanchez 